\title{
Regression Models of Monthly Water-Level Change In and Near The Closed Basin Division of the San Luis Valley, South-Central Colorado
}

by Kenneth $R$. Watts

U.S. GEOLOGICAL SURVEY

Water-Resources Investigations Report 93-4209

Prepared in cooperation with the

BUREAU OF RECLAMATION

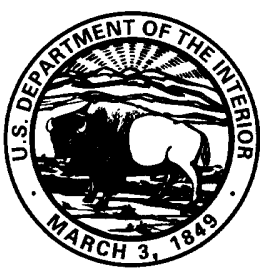




\title{
U.S. DEPARTMENT OF THE INTERIOR BRUCE BABBITT, Secretary
}

\author{
U.S. GEOLOGICAL SURVEY
}

Gordon P. Eaton, Director

The use of trade, product, industry, or firm names is for descriptive purposes only and does not imply endorsement by the U.S. Government.

For additional information write to:

Copies of this report can be purchased from:

District Chief

U.S. Geological Survey

Box 25046, MS 415

Denver Federal Center

Denver, CO 80225
U.S. Geological Survey

Earth Science Information Center

Open-File Reports Section

Box 25286, MS 517

Denver Federal Center

Denver, CO 80225 


\section{CONTENTS}

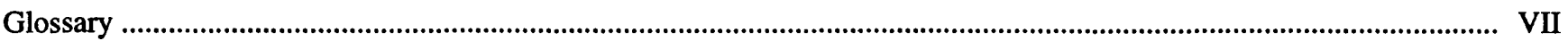

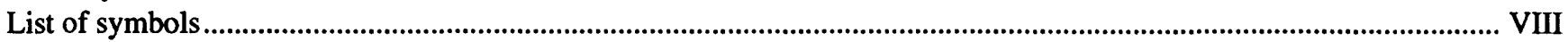

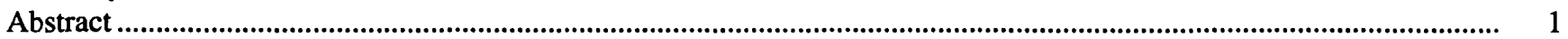

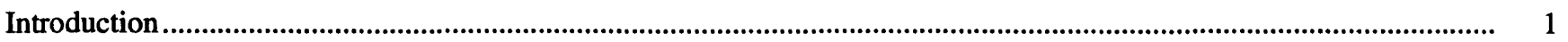

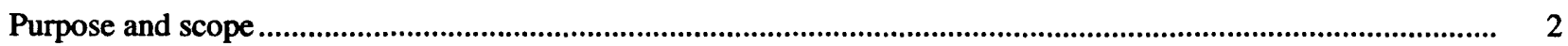

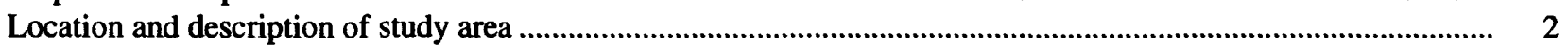

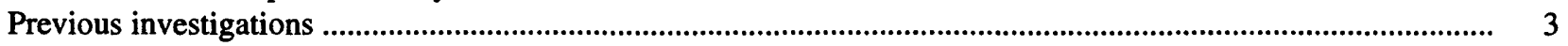

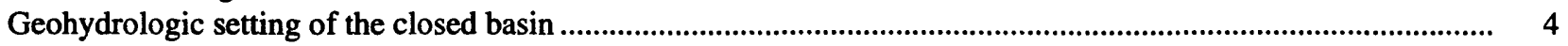

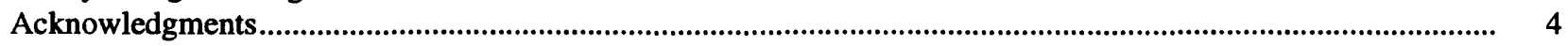

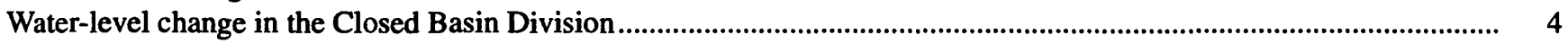

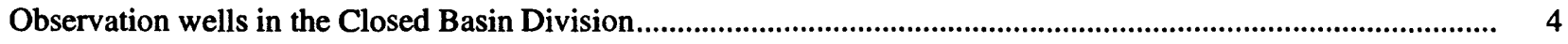

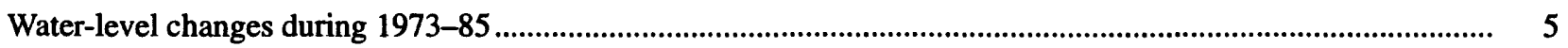

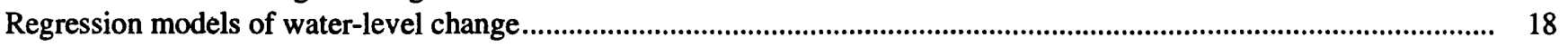

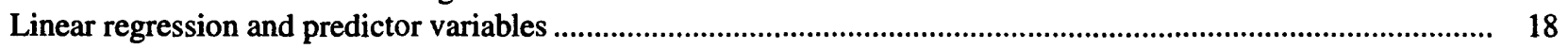

Harmonic variation of variables related to recharge and discharge ............................................................ 19

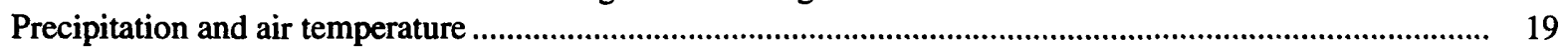

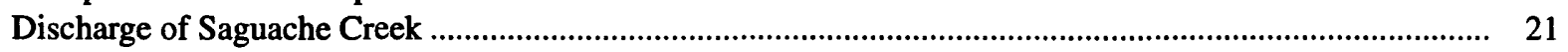

Streamflow depletion of the Rio Grande between Del Norte and Trinchera Creek.................................... 21

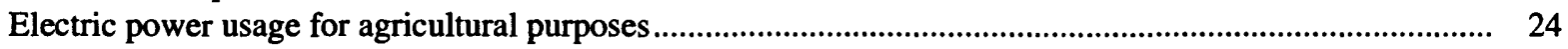

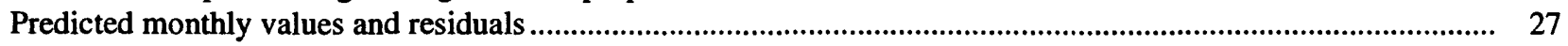

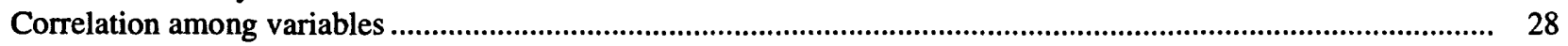

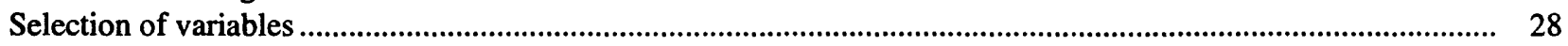

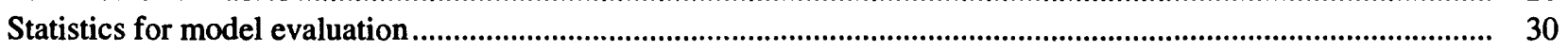

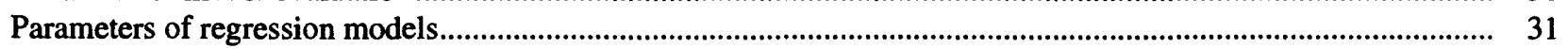

Predicting post-1985 monthly water-level changes with regression models .................................................................44

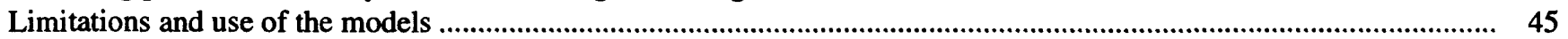

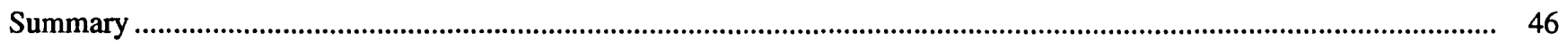

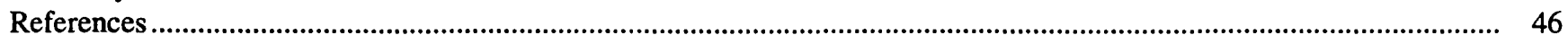

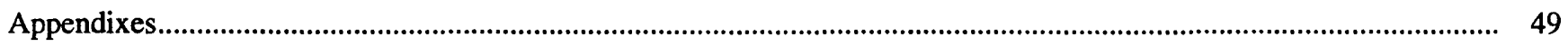

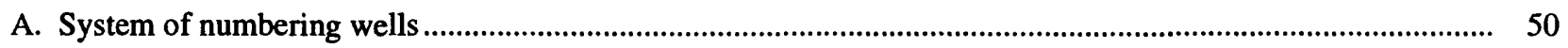

B. Hydrographs of observed and predicted water-level change, upper and lower confidence limits, and residual errors for selected observation wells in the Closed Basin Division study area ............................. 52

C. V matrices for regression models of water-level change in the Closed Basin Division study area .................... 90

\section{PLATE}

[In pocket]

1. Map showing the location of the Closed Basin Division, selected wells, climatological stations, and gaging stations 
1. Map showing location of the Closed Basin Division, San Luis Valley

2-9. Hydrographs showing monthly depth to water and monthly water-level change at observation well:

2. RGWCD 14, closed basin of San Luis Valley

3. RGWCD 18, closed basin of San Luis Valley

4. RGWCD 23, closed basin of San Luis Valley

5. RGWCD 58, closed basin of San Luis Valley

6. USBR EW 2U, closed basin of San Luis Valley

7. USBR EW 19U, closed basin of San Luis Valley

8. USBR PW 4-4, closed basin of San Luis Valley

9. USBR SNIPPY, closed basin of San Luis Valley

10-15. Graphs showing:

10. (A) Monthly precipitation in the closed basin of San Luis Valley and a harmonic model of monthly precipitation; and (B) the residual, 1973-85

11. (A) Monthly mean air temperature at Alamosa WSO AP and a harmonic model of monthly mean air temperature; and (B) the residual, 1973-85

12. (A) Monthly mean discharge of Saguache Creek near Saguache and a harmonic model of monthly mean discharge; and (B) the residual, 1973-85.

13. (A) Monthly mean streamflow depletion of the Rio Grande between Del Norte and Trinchera Creek and a harmonic model of monthly mean depletion; and (B) the residual, 1973-85.

14. (A) Monthly electric power usage for agricultural purposes supplied by the San Luis Valley Rural Electric Cooperative and a harmonic model of monthly electrical use; and (B) the residual, 1973-85.

15. Serial correlation of first-stage predictor variables $X_{c}, X_{s}, P P, T A, R O, S W$, and GW for regression models of water-level change in the Closed Basin Division study area.

ydrographs showing (A) observed and predicted monthly water-level change and confidence

16-24. Hydrographs showing (A) observed and predicted mon
limits; and (B) residual errors for observation well:

16. RGWCD 14, closed basin of San Luis Valley.

17. RGWCD 18, closed basin of San Luis Valley

18. RGWCD 23, closed basin of San Luis Valley.

19. RGWCD 58, closed basin of San Luis Valley.

20. USBR EW 2U, closed basin of San Luis Valley

21. USBR EW 19U, closed basin of San Luis Valley

22. USBR EW 26U, closed basin of San Luis Valley

23. USBR PW 4-4, closed basin of San Luis Valley..............

24. USBR SNIPPY, closed basin of San Luis Valley.

A-1. Diagram showing system of numbering wells in Colorado

B-1-B-37. Hydrographs showing (A) observed and predicted water-level change and confidence limits; and

(B) residual errors for observation well:

B-1. RGWCD 15, closed basin of San Luis Valley

B-2. RGWCD 24A, closed basin of San Luis Valley

B-3. RGWCD 27, closed basin of San Luis Valley....

B-4. RGWCD 41, closed basin of San Luis Valley .

B-5. RGWCD 42, closed basin of San Luis Valley.

B-6. RGWCD 45A, closed basin of San Luis Valley

B-7. RGWCD 47, closed basin of San Luis Valley...

B-8. RGWCD 59A, closed basin of San Luis Valley

B-9. USBR EW 8U, closed basin of San Luis Valley .

B-10. USBR EW 9U, closed basin of San Luis Valley

B-11. USBR EW 11U, closed basin of San Luis Valley

B-12. USBR EW 12U, closed basin of San Luis Valley

B-13. USBR EW 14U, closed basin of San Luis Valley

B-14. USBR EW 16U, closed basin of San Luis Valley 
B-15. USBR EW 20U, closed basin of San Luis Valley ............................................................................. 67

B-16. USBR EW 21U, closed basin of San Luis Valley ................................................................................. 68

B-17. USBR EW 22C, closed basin of San Luis Valley ........................................................................... 69

B-18. USBR EW 23U, closed basin of San Luis Valley ........................................................................... 70

B-19. USBR EW 24U, closed basin of San Luis Valley ............................................................................. 71

B-20. USBR EW 32C, closed basin of San Luis Valley ...................................................................... 72

B-21. USBR EW 32U, closed basin of San Luis Valley ....................................................................... 73

B-22. USBR EW 33C, closed basin of San Luis Valley ............................................................................... 74

B-23. USBR EW 33U, closed basin of San Luis Valley ........................................................................... 75

B-24. USBR EW 34C, closed basin of San Luis Valley ............................................................................. 76

B-25. USBR EW 34U, closed basin of San Luis Valley ............................................................................... 77

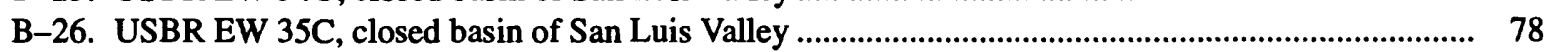

B-27. USBR EW 35U, closed basin of San Luis Valley ............................................................... 79

B-28. USBR EW 39C, closed basin of San Luis Valley ................................................................. 80

B-29. USBR EW 39U, closed basin of San Luis Valley .................................................................. 81

B-30. USBR EW 40C, closed basin of San Luis Valley ............................................................................. 82

B-31. USBR EW 40U, closed basin of San Luis Valley ....................................................................... 83

B-32. USBR PW 1-7, closed basin of San Luis Valley .............................................................. 84

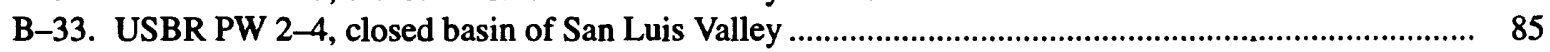

B-34. USBR PW 2-5, closed basin of San Luis Valley ........................................................................ 86

B-35. USBR PW 4-1, closed basin of San Luis Valley .................................................................. 87

B-36. USBR PW 4-5, closed basin of San Luis Valley ................................................................ 88

B-37. USBR PW 5-2, closed basin of San Luis Valley .................................................................. 89

\section{TABLES}

1. Location and construction data for selected observation wells in the Closed Basin Division study area

2. Summary statistics of monthly water-level changes for selected observation wells in the Closed Basin Division study area, 1973-85.

3. Monthly values for the harmonic functions $X_{c}$ and $X_{s}$ and predicted monthly values of $\overline{P P}, \overline{T A}, \overline{R O}, \overline{S W}$,

4. Pearson correlation coefficients and exceedance probabilities for the predictor variables used in regression

models of water-level change in the Closed Basin Division study area .............................................................

level change in the Closed Basin Division study area 
CONVERSION FACTORS AND VERTICAL DATUM

\begin{tabular}{|c|c|c|}
\hline Multiply & By & To obtain \\
\hline $\begin{array}{r}\text { acre } \\
\text { acre-foot (acre-ft) } \\
\text { acre-foot per year (acre-ft/yr) }\end{array}$ & $\begin{array}{l}4,047 \\
1,233 \\
1,233\end{array}$ & $\begin{array}{l}\text { square meter } \\
\text { cubic meter } \\
\text { cubic meter per year }\end{array}$ \\
\hline $\begin{array}{r}\text { cubic foot per second }\left(\mathrm{ft}^{3} / \mathrm{s}\right) \\
\text { foot }(\mathrm{ft})\end{array}$ & $\begin{array}{l}28.32 \\
.3048\end{array}$ & $\begin{array}{l}\text { liter per second } \\
\text { meter }\end{array}$ \\
\hline gigawatt-hour (gWh) & $3.6 \times 10^{12}$ & joules \\
\hline kilowatt-hour (kWh) & $3.6 \times 10^{6}$ & joules \\
\hline mile $(\mathrm{mi})$ & 1.609 & kilometer \\
\hline megawatt-hour (mWh) & $3.6 \times 10^{9}$ & joules \\
\hline square mile $\left(\mathrm{mi}^{2}\right)$ & 2.59 & square kilometer \\
\hline
\end{tabular}

Degree Fahrenheit $\left({ }^{\circ} \mathrm{F}\right)$ may be converted to degree Celsius $\left({ }^{\circ} \mathrm{C}\right)$ by using the following equation:

$$
{ }^{\circ} \mathrm{C}=5 / 9\left({ }^{\circ} \mathrm{F}-32\right) \text {. }
$$

Sea level: In this report "sea level" refers to the National Geodetic Vertical Datum of 1929 (NGVD of 1929)-a geodetic datum derived from a general adjustment of the first-order level nets of both the United States and Canada, formerly called Sea Level Datum of 1929. 


\section{GLOSSARY}

The following terms are italicized where first used in this report.

adjusted coefficient of determination $\left(R_{a}{ }^{2}\right)$.-A measure of the adequacy of a regression model. The statistic is defined as follows:

$R_{a}^{2}=1-((n-1) /(n-p))\left(1-R_{p}^{2}\right)$ where $\mathrm{n}$

is the number of observations, $p$ is the number of predictor variables in the regression, including the intercept, and $R_{p}{ }^{2}$ is the coefficient of multiple determination. The $\mathrm{R}_{\mathrm{a}}{ }^{2}$-statistic, unlike the $\mathrm{R}_{\mathrm{p}}{ }^{2}$-statistic, does not necessarily increase as additional predictor variables are introduced to the model (see coefficient of multiple determination).

autoregression.-Regression of a variable on its previous values. First-order autoregression is regression of a variable on its immediately preceding values.

coefficient of determination $\left(R^{2}\right)$.-The proportion of variation in the response variable explained by regression

$$
\text { with a predictor variable. } R^{2}=1-\frac{\Sigma\left(y_{i}-\hat{y}_{i}\right)^{2}}{\Sigma\left(y_{i}-\bar{y}\right)^{2}}
$$

where $y_{i}$ is the observed $i^{\text {th }}$ response, $\hat{y}_{i}$ is the predicted

$\mathrm{i}^{\text {th }}$ response, and $\bar{y}$ is the mean response.

coefficient of multiple determination $\left(R_{p}{ }^{2}\right)$. - The proportion of variation in the response variable explained by regression with more than one predictor variable. $R_{p}{ }^{2}$ increases as the number of predictor variables increases. Defining equation is the same as for coefficient of determination.

collinearity.-Linear relation between predictor variables. The relation may be exact or approximate.
Durbin-Watson test.-A test of the residual errors for correlation between adjacent cases. The test is based on the assumption that the errors in the regression are generated by a first-order serially correlated process and that observations are made at equal time intervals (Montgomery and Peck, 1982, p. 349-353).

Mallows' $C_{p}$ statistic.-A statistic proposed by Mallows (1973) for evaluating a p-term subset regression model; $C_{p}$ is related to the mean square error of the fitted value. Regression equations with little bias will have a $C_{p}$ value approximately equal to the number of terms ( $p$ ) in the regression model. For a detailed explanation of the use of Mallows' $C_{p}$ statistic, see Montgomery and Peck (1982, p. 252-254).

mean square error (MSE). - The mean square of the residual errors. $M S E=\sum_{i=1}^{n} e_{i} 2 /(n-2)$

where $e_{i}$ is the $i^{\text {th }}$ residual error and $n$ is the number of observations. Sometimes indicated as the error mean square or residual mean square.

predictor variable. - In a regression equation, a variable whose value is known and which is used to predict the value of a response variable; sometimes referred to as an independent variable.

residual.-Residual error.

residual error.-The difference between the observed and predicted values of the response variable in a regression model.

response variable.-In a regression equation, the variable whose value is predicted based on its statistical relation with a predictor variable; sometimes referred to as the dependent variable.

serial correlation.-Correlation between observations in time-ordered sequences of observations. First-order serial correlation refers to correlation between consecutive observations. Also indicated as autocorrelation. standard error(s) of estimate.-Standard deviation of residual errors. 


\section{LIST OF SYMBOLS}

$a_{1}$

$a_{s}$

$B_{0}$

$B_{1}-B_{k}$

$B_{R G W}$

$B_{R P P}$

$B_{R R O}$

$B_{R S W}$

$B_{R T A}$

$B_{T}$

$B_{X_{c}}$

$B_{X_{s}}$

$C_{p}$

$d$

$d_{L}$

$d_{U}$

$e_{i}$

$G W$

$H_{0}$

$H_{a}$

$i$

$k$

MSE

m

n

$P P$

$p$ model.
First-order serial correlation coefficient.

All serial correlations coefficient.

Intercept for regression model.

Regression parameters for predictor variables $X_{1}$ through $X_{k}$.

Regression parameter for RGW.

Regression parameter for RPP.

Regression parameter for RRO.

Regression parameter for RSW.

Regression parameter for RTA.

Regression parameter for $\mathrm{T}$, elapsed time.

Regression parameter for $\mathrm{X}_{\mathrm{c}}$, harmonic cosine function.

$R^{2}$

$R_{a}^{2}$

$R_{p}{ }^{2}$

$R G W$

$R O$

$R P P$

$R R O$

$R S W$

Regression parameter for $\mathrm{X}_{\mathrm{s}}$, harmonic sine function.

Mallows' $\mathrm{C}_{\mathrm{p}}$ statistic.

Durbin-Watson test statistic.

Lower critical value in Durbin-Watson test.

Upper critical value in Durbin-Watson test.

$i^{\text {th }}$ residual error.

Monthly electrical use for agricultural purposes ( $\mathrm{gWh}$ )

Null hypothesis.

Alternate hypothesis.

Observation index.

Number of predictor variables in a regression

Mean square error.

Month of the year (January = 1, February = 2, ..., December $=12$ ).

Number of observations.

Monthly precipitation (in.).

Number of regression parameters or terms, including the intercept, in a regression model.
Coefficient of determination.

Adjusted coefficient of determination. Coefficient of multiple determination.

Residual of GW from harmonic regression model.

Monthly mean discharge of Saguache Creek near Saguache $\left(\mathrm{ft}^{3} / \mathrm{s}\right)$.

Residual of PP from harmonic regression model.

Residual of RO from harmonic regression model.

Residual of SW from harmonic regression model.

RTA Residual of TA from harmonic regression model.

$S_{i} \quad$ Water-level change ( $\mathrm{ft}$ ) for $\mathrm{i}^{\text {th }}$ month.

$S E_{e} \quad$ Standard error of estimate.

$S W \quad$ Monthly mean streamflow depletion of Rio Grande between Del Norte and Trinchera Creek $\left(\mathrm{ft}^{3} / \mathrm{s}\right)$.
$T$

$t$

$T A$

$v$

$x_{l i} \ldots x_{k i}$

$\boldsymbol{x}_{i}$

$X_{c}$

$X_{s}$

$y_{i}$

$\alpha$

$\beta$
Elapsed time (months, starting with January 1973).

Student's t statistic.

Monthly mean air temperature $\left({ }^{\circ} \mathrm{F}\right)$.

An autoregressive error term.

Predictor variables for the $\mathrm{i}^{\text {th }}$ observation.

A vector of predictor variables for the $i^{\text {th }}$ observation.

Harmonic cosine function with annual period.

Harmonic sine function with annual period. Response variable for the $i^{\text {th }}$ observation. Significance level.

A vector of regression parameters. Indicates a predicted value. 


\title{
Regression Models of Monthly Water-Level Change In and Near the Closed Basin Division of the San Luis Valley, South-Central Colorado
}

\author{
By Kenneth R. Watts
}

\begin{abstract}
The Bureau of Reclamation is developing a water-resource project, the Closed Basin Division, in the San Luis Valley of south-central Colorado that is designed to salvage unconfined ground water that currently is discharged as evapotranspiration. The water table in and near the 130,000-acre Closed Basin Division area will be lowered by an annual withdrawal of as much as 100,000 acre-feet of ground water from the unconfined aquifer. The legislation authorizing the project limits resulting drawdown of the water table in preexisting irrigation and domestic wells outside the Closed Basin Division to a maximum of 2 feet. Water levels in the closed basin in the northern part of the San Luis Valley historically have fluctuated more than 2 feet in response to water-use practices and variation of climatically controlled recharge and discharge. Declines of water levels in nearby wells that are caused by withdrawals in the Closed Basin Division can be quantified if water-level fluctuations that result from other water-use practices and climatic variations can be estimated. This study was done to evaluate water-level change at selected observation wells in and near the Closed Basin Division.
\end{abstract}

Regression models of monthly water-level change were developed to predict monthly waterlevel change in 46 selected observation wells. Predictions of monthly water-level change are based on one or more of the following: elapsed time, cosine and sine functions with an annual period, streamflow depletion of the Rio Grande, electrical use for agricultural purposes, runoff into the closed basin, precipitation, and mean air temperature. Regression models for five of the wells include only an intercept term and either an elapsed-time term or terms determined by the cosine and sine functions. Regression models for the other 41 wells include 1 to 4 of the 5 other variables, which can vary from month to month and from year to year. Serial correlation of the residuals was detected in 24 of the regression models. These models also include an autoregressive term to account for serial correlation in the residuals. The adjusted coefficient of determination $\left(R_{a}{ }^{2}\right)$ for the 46 regression models range from 0.08 to 0.89 , and the standard errors of estimate range from 0.034 to 2.483 feet. The regression models of monthly water-level change can be used to evaluate whether post- 1985 monthly waterlevel change values at the selected observation wells are within the 95-percent confidence limits of predicted monthly water-level change.

\section{INTRODUCTION}

The Bureau of Reclamation (USBR) is constructing (1992) a multipurpose water-resources project, known as the Closed Basin Division of the San Luis Valley project in south-central Colorado. Construction of the Closed Basin Division was authorized by Public Law 92-514, which was enacted by Congress on October 20,1972. The project was designed on the assumption that annual withdrawal of as much as 100,000 acre-ft of water from the unconfined aquifer by a well field in the Closed Basin Division would lower the water table and thereby salvage some of the ground water that is naturally discharged by evapotranspiration. The authorizing legislation specifies that drawdown of the water table that is caused by pumping of the salvage wells is limited so that it will not cause the water table for any irrigation of domestic wells in existence outside the project boundary prior to construction of the project to drop more than $2 \mathrm{ft}$. In addition, operation of the Closed Basin Division is not to appreciably affect potentiometric levels in production wells completed in the confined aquifer system. Prior to operation of the well field, variations in recharge and discharge rates in the area have caused water levels in and near the 
Closed Basin Division to fluctuate more than $2 \mathrm{ft}$. Drawdowns that are caused by withdrawals from the well field in the Closed Basin Division cannot be determined unless water-level changes caused by variation in other recharge and discharge rates can be predicted. This study was done by the U.S. Geological Survey, in cooperation with the Bureau of Reclamation, to evaluate 1978-85 water-level change in and near the Closed Basin Division and to develop statistical models of water-level change.

\section{Purpose and Scope}

This report describes the results of an evaluation of water-level change in 46 selected observation wells in and near the Closed Basin Division. Of particular interest was the component of water-level change that was caused by variation in regional recharge and discharge conditions prior to 1986 and operation of salvage wells in the Closed Basin Division. The report presents regression models of monthly water-level change for the selected observation wells. Simplelinear and multiple-linear regression models of monthly water-level change, some with autoregressive terms, are shown for the selected observation wells. Predictor variables used in the regression analyses include elapsed time, harmonic functions of time, and variables related to regional recharge and discharge: streamflow depletion of the Rio Grande, electric power use for agricultural (irrigation) purposes, runoff into the closed basin, precipitation, and mean air temperature.

Water-level data used in this study were retrieved from computer files maintained by the U.S. Geological Survey. Monthly mean water levels for wells equipped with continuous recorders were computed from daily mean values retrieved from the National Water Data Storage and Retrieval System (WATSTORE) of the U.S. Geological Survey. Mid-month values were used where the record of daily mean values for a month was incomplete. Monthly water-level measurements for wells without continuous record were retrieved from the Ground-Water Site Inventory (GWSI) system of the U.S. Geological Survey. When more than one waterlevel measurement for an observation well was available from GWSI for a given month, the water-level measurement made nearest to mid-month was used.

Monthly values of variables related to regional recharge and discharge were obtained from several sources. Climatological data were obtained from annual climatic summaries (National Oceanic and Atmospheric Administration, 1973-85). Monthly mean discharge of the Rio Grande and of Saguache
Creek were retrieved from WATSTORE and from the Office of the State Engineer, Colorado Department of Natural Resources. Monthly electric power use by agricultural customers was provided by the San Luis Valley Rural Electric Cooperative (REC), Del Norte (John Sheppard, San Luis Valley Rural Electric Cooperative, Del Norte, Colo., written commun., 1985).

\section{Location and Description of Study Area}

The study area (fig. 1) includes the area within about $3 \mathrm{mi}$ of the boundary of the Closed Basin Division. Most of the study area is in the closed basin of the San Luis Valley of south-central Colorado. The San Luis Valley in Colorado is the area underlain by valley-fill deposits between the San Juan Mountains and the Sangre de Cristo Mountains. In this report, the term, "closed basin," refers to the part of the San Luis Valley north of the topographic divide between the Rio Grande Basin and the basin of San Luis and Saguache Creeks. The southern parts of the study area and of the Closed Basin Division are south of the topographic divide that is the southern boundary of the closed basin. The closed basin is about $1,615 \mathrm{mi}^{2}$ in extent and includes parts of Alamosa, Costilla, Rio Grande, and Saguache Counties. Land-surface altitude in the Closed Basin Division ranges from about 7,500 to $7,650 \mathrm{ft}$.

The climate of the closed basin is arid, and irrigation is required to grow crops in the area. The main irrigated area in the closed basin is located west and southwest of the Closed Basin Division. Sources of water for irrigation in the closed basin are surface water diverted from the Rio Grande and other streams flowing into the closed basin and ground water withdrawn from the unconfined and underlying confined aquifers. The Closed Basin Division of the San Luis Valley project includes an area of about 130,000 acres that is located along the topographic low of the closed basin. The project, when completed, will include about 170 salvage wells designed to withdraw up to 100,000 acre-ft/yr of ground water from the unconfined aquifer (Lawrence F. Parsons, Bureau of Reclamation, written commun., 1990). Authorized uses of water withdrawn by the Closed Basin Division well field are supplementation of flow in the Rio Grande, maintenance of wildlife habitat, recreational use, and other beneficial uses.

2 Regression Models of Monthly Water-Level Change In and Near the Closed Basin Division of the San Luis Valley, South-Central Colorado 


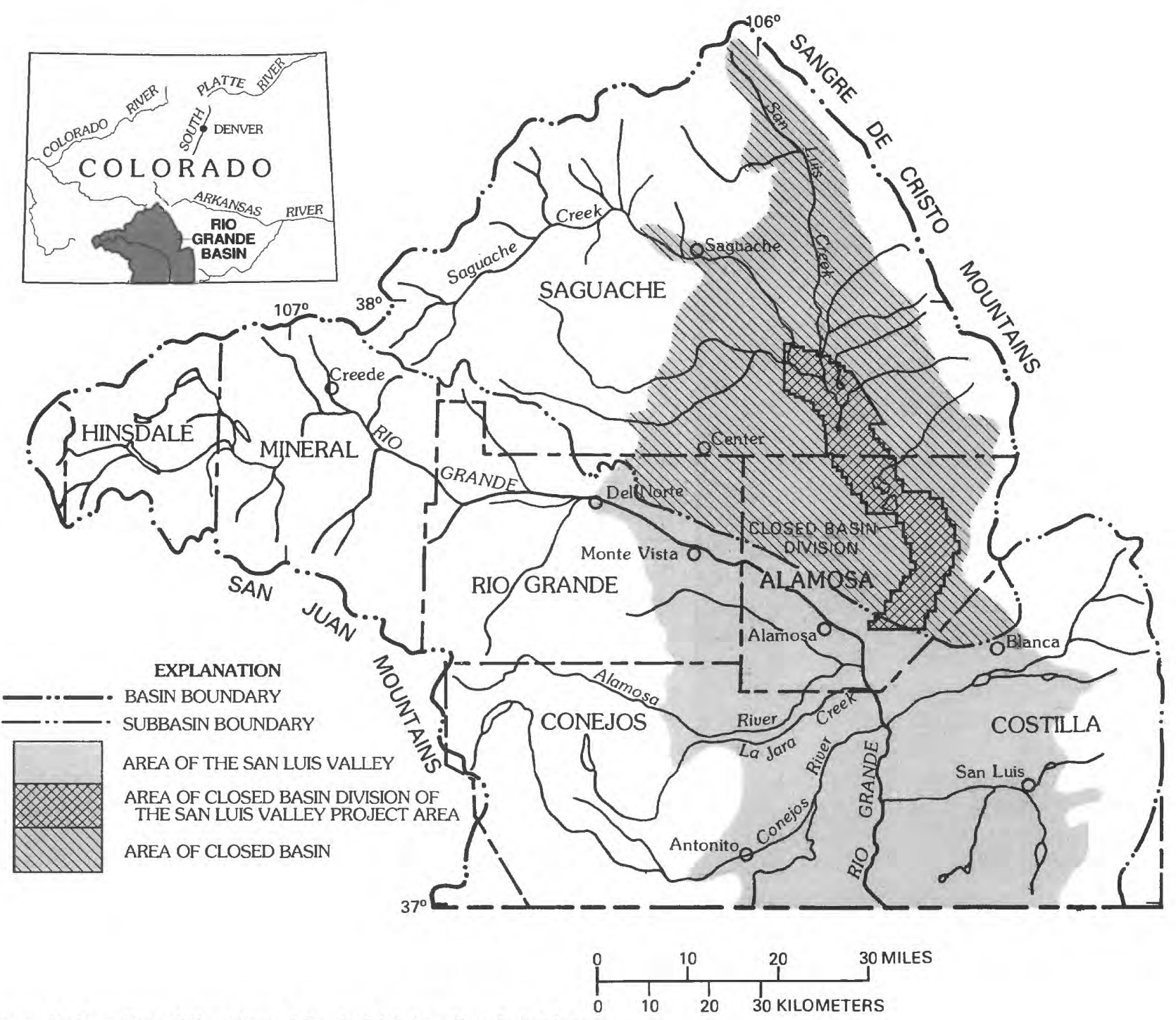

Figure 1. Location of the Closed Basin Division, San Luis Valley.

\section{Previous Investigations}

Descriptions of the hydrogeology of the San Luis Valley are provided by Siebenthal (1910) and Powell (1958). HRS Water Consultants and Moran (1987) provide an annotated bibliography of reports on the geology and water resources of the San Luis Valley. Powell (1958, p. 61-74) compared 1949-52 waterlevel fluctuations in the unconfined aquifer with variation in precipitation and other sources of recharge and sinks for discharge. Crouch (1985) presented maps of the 1980 potentiometric surface for the unconfined aquifer and 1969-80 water-level changes in the unconfined aquifer of the San Luis Valley. Crouch described the general relation of 1969-80 water-level change to annual surface-water diversions and estimated ground-water pumpage. Investigators (Emery, 1970; Emery and others, 1975; Huntley, 1979; Hearne and
Dewey, 1988; Leonard and Watts, 1989) used groundwater flow models to evaluate the water budget and, except for Huntley (1979), to predict aquifer response to hypothetical withdrawals by proposed water-salvage systems in the sump of the closed basin. Regression models previously have not been used in evaluating water-level changes in the San Luis Valley.

Regression models have been used to model water-level change in other areas. Tasker and Guswa (1978) regressed water-level changes with elapsed time and harmonic functions of time to estimate daily water levels from observations less frequent than daily for an observation-well network at Cape Cod, Mass. Houston (1983) used multiple-linear regression, based on pumping rates and prior rainfall, to estimate waterlevel change in a well field. Houston emphasizes that regression models differ from, and are not substitutes for, analytical or numerical models. Hodgson (1978) 
used multiple-linear regression models with autoregressive terms to model a time series of water levels. Hodgson noted that water-table change can be predicted with reasonable confidence only between limits of previous fluctuations of the water table. Jackson (1973) used regression to examine climatological and hydrogeological variables associated with a groundwater discharge area in Manitoba, Canada, and to estimate daily ground-water evapotranspiration and inflow rates.

\section{Geohydrologic Setting of the Closed Basin}

The geohydrology of the study area is complex and incompletely defined. The San Luis Valley is underlain by several thousand feet of unconsolidated clay, silt, sand, and gravel, which typically are in lenticular and gradational deposits. These deposits locally are interbedded with volcanic flows and volcaniclastic rocks that were deposited in a complexly faulted basin. Locally, post-depositional faulting has modified lateral continuity of the deposits. Hearne and Dewey (1988, p. 7) refer to the aquifer system as "a heterogeneous mixture of aquifers and leaky confining beds, each of limited areal extent and variable hydraulic properties." The aquifer system is a thick, multilayered system that consists of an upper, relatively thin, unconfined aquifer and an underlying thick sequence of leaky confining units and confined aquifers. The confining units consist of clay or volcanic rocks and generally are discontinuous.

Ground-water recharge in the closed basin consists of deep percolation of irrigation water applied in excess of crop-consumptive use and soil-moisture capacity, infiltration of surface water, precipitation in excess of evapotranspiration and soil-moisture capacity, and ground-water underflow. Ground-water discharge in the closed basin consists of ground-water withdrawals for irrigation, evapotranspiration in areas where the water table is near ground surface, and ground-water underflow.

Development of irrigation in the closed basin has altered the natural ground-water flow system. Powell (1958, p. 56) states that "before the lands on the west side of the valley were placed under irrigation, the water table was reported to have been 50 to $100 \mathrm{ft}$ below ground surface, which is near the level of the first substantial layer of clay at or near the base of the shallow aquifer that now supplies thousands of acre-feet of unconfined ground water annually for irrigation." Since the 1950 's, changes in the sources and rates of ground-water withdrawal for irrigation, changes in methods of irrigation, and variation in surface-water diversions have caused ground-water levels to fluctuate. Water levels in the unconfined aquifer declined 5 to about $30 \mathrm{ft}$ during 1969-80 in the irrigated area southwest of the Closed Basin Division (Crouch, 1985 , sheet 1) as a result of increased ground-water withdrawals and variation in surface-water diversions.

\section{Acknowledgments}

The author acknowledges the Office of the State Engineer of the Colorado Department of Natural Resources, Denver, Colo., which provided unpublished discharge data for Saguache Creek near Saguache for October 1982 through December 1985. The author acknowledges John Sheppard of the San Luis Valley REC, Del Norte, Colo., who provided 1973-85 monthly electrical use for agricultural purposes in the cooperative's service area of the San Luis Valley. The report was edited by Carol L. Anderson; manuscript preparation was by Ann Marie Squillacci and Joy K. Monson; and illustrations were prepared by James R. Garcia, Sharon M. Powers, and Bruce S. Galoob.

\section{WATER-LEVEL CHANGE IN THE CLOSED BASIN DIVISION}

Water levels in the Closed Basin Division fluctuate in response to temporal and spatial variations of natural recharge and discharge, nearby water use for irrigation, and external stresses, such as changes in barometric pressure. Water-level changes that are caused by short-term variation of external stresses are transient and do not substantially affect ground-water storage. Therefore, the effects of variation of external stresses were not evaluated in this study. Temporal (seasonal and long-term) and spatial variations of natural recharge, natural discharge, and man's water-use practices are the primary causes of water-level change in the study area. Because spatial variations in recharge and discharge in the study area are poorly documented, only temporal variations in regional recharge and discharge are considered in this report.

\section{Observation Wells in the Closed Basin Division}

The USBR and the Rio Grande Water Conservation District (RGWCD) measured water levels in many observation wells in and near the Closed Basin Division. The USBR network included 34 observation wells that had a continuous record during 1984-85. The RGWCD network included 12 observation wells in or within $3 \mathrm{mi}$ of the Closed Basin Division that were measured monthly or more frequently during 1984-85. Other observation wells in the RGWCD and USBR networks are not considered in this report because measurements

4 Regression Models of Monthly Water-Level Change In and Near the Closed Basin Division of the San Luis Valley,

South-Central Colorado 
were discontinued prior to 1985 , measurements were not made on at least a monthly basis, the observation wells were outside the study area, or data were not available in the data bases of the U.S. Geological Survey. The locations of the 46 selected observation wells that were considered in this report are shown on plate 1 . The well name, land-net location, type of aquifer(s) in which the well is screened, and construction data for the selected observation wells are listed in table 1. (The land-net-location numbering system is explained in the Appendix A section at the back of the report.) Well names used in this report are based on the abbreviated name of the collecting agency, RGWCD or USBR, and the collecting agency's identification numbers or names for the wells. For example, observation well 14 in the RGWCD network is indicated as RGWCD 14 and well EW $2 \mathrm{U}$ in the USBR network, as USBR EW 2U.

Some of the selected observation wells are completed in the unconfined aquifer at depths considerably below the water table; for these wells, water levels may be slightly above or below the water table. However, for simplicity in this report, the potentiometric surface defined by water levels in observation wells screened in the unconfined aquifer(s) is referred to as the water table. Water levels in observation wells screened in confined aquifer(s) are referred to as potentiometric levels. The datum for all water-level measurements is the land surface at the well.

\section{Water-Level Changes During 1973-85}

Water levels in the San Luis Valley of Colorado, particularly in the irrigated areas in the southwestern part of the closed basin, generally declined during the 1970's. Crouch (1985) attributes the decline of the water table to an increase in ground-water withdrawals for irrigation of increased irrigated acreage and to a decrease in surface-water diversions. Because much of the recharge to the unconfined aquifer is from infiltration of water from surface-water diversions, the decrease in surface-water diversions results in decreased ground-water recharge. A decrease in surface-water diversions also may result indirectly in increased ground-water withdrawals if ground-water use is increased to compensate for the decrease in use of surface water.

Water levels in the study area, although more stable than water levels in irrigated areas, have declining trends in some wells. Because withdrawal from the salvage wells were minimal prior to 1986 , the changes in water levels in the study area are assumed to have resulted from variation in natural recharge and discharge rates and in water use outside the Closed
Basin Division. Hydrographs of monthly depth-to-water and monthly water-level change for eight selected wells (figs. 2 through 9) indicate a varied response in the study area. (Note: The scale for water-level change in figures 2 through 9 is reversed so that water-level declines plot below and rises above the zero-change line.) Water levels declined in some wells, such as RGWCD 14, RGWCD 18, RGWCD 23, USBR PW 4-4, and USBR SNIPPY (figs. 2 through 4, 8, and 9) during the 1970's. Some wells, such as RGWCD 58 (fig. 5), had erratic trends; other wells, such as USBR EW 19U (fig. 7), had little long-term trend. Although water levels in some wells began increasing during the late 1970's and early-to-middle 1980's (figs. 2, 5, and 8), water levels in others continued a downward trend (figs. 3, 4, 6, and 9).

Monthly water-level change values (figs. 2 through 9) were calculated as the depth-to-water value for a particular month minus the depth-to-water value for the previous month; therefore, a water-level decline is a positive water-level change, and a waterlevel rise is a negative water-level change. In a complete series of depth-to-water values, there is one less waterlevel change value than there are depth-to-water values. Missing depth-to-water values in the series result in the loss of additional water-level change values. (Note that the lines connecting monthly depth-to-water values [figs. 2 through 9] are shown only for visual reference and cannot be used to interpolate intermediate or missing values.)

Summary statistics of the monthly water-level changes for the 46 selected observation wells are listed in table 2. Because the number of monthly water-level change observations varies from well to well, direct comparison of the summary statistics between wells with unequal numbers of values is not appropriate. The number of monthly water-level change values ranges from 20 for USBR EW 35U to 117 for RGWCD 23. The average of the mean monthly water-level change values for the 8 wells that have more than 80 observations (table 2) is $-0.027 \mathrm{ft}$, a water-level rise. Long-term (December 1975 to December 1985) water-level change at the 8 observation wells that had more than 80 monthly water-level measurements ranged from a rise of $-3.29 \mathrm{ft}$ at RGWCD 14 to a decline of $12.39 \mathrm{ft}$ at RGWCD 23 . Long-term water-level change at these eight wells was an average decline of $1.05 \mathrm{ft}$. However, if water-level change at RGWCD 23 is not included in the average, the long-term water-level change was an average rise of $-0.56 \mathrm{ft}$. Monthly water-level change values for the unconfined aquifer (table 2) range from a rise of $-4.97 \mathrm{ft}$ (RGWCD 41) to a decline of $5.41 \mathrm{ft}$ (RGWCD 23). Sample standard deviations of monthly water-level change for the 8 wells that have more than 80 observations range from 0.422 (RGWCD 42) to $1.461 \mathrm{ft}$ (RGWCD 23). 
Table 1. Location and construction data for selected observation wells in the Closed Basin Division study area

[Land-net location numbering system is explained in Appendix $A$ at the back of the report. Aquifer-type codes-U $=$ unconfined aquifer with a single contributing interval, $\mathrm{N}=$ unconfined aquifer with multiple contributing intervals, and $\mathrm{C}=$ confined aquifer with a single contributing interval. All depths are reported in feet below land surface datum. Casing-material codes-G = galvanized iron, $P=$ plastic, $S=$ steel. Opening-type codes-P = perforated or slotted and $S=$ unknown screen. Dashes indicate data not available]

\begin{tabular}{|c|c|c|c|c|c|c|c|c|}
\hline $\begin{array}{c}\text { Well } \\
\text { name } \\
\text { (see pl. } 1 \\
\text { for location) }\end{array}$ & $\begin{array}{l}\text { Land-net } \\
\text { location }\end{array}$ & $\begin{array}{l}\text { Aquifer- } \\
\text { type } \\
\text { code }\end{array}$ & $\begin{array}{l}\text { Well } \\
\text { depth } \\
\text { (feet) }\end{array}$ & $\begin{array}{l}\text { Depth } \\
\text { to } \\
\text { top of } \\
\text { open } \\
\text { Interval } \\
\text { (foet) }\end{array}$ & $\begin{array}{l}\text { Depth } \\
\text { to } \\
\text { bottom of } \\
\text { open } \\
\text { Interval } \\
\text { (feet) }\end{array}$ & $\begin{array}{c}\text { Diameter } \\
\text { of } \\
\text { open } \\
\text { Interval } \\
\text { (Inches) }\end{array}$ & $\begin{array}{l}\text { Casing } \\
\text { materlal }\end{array}$ & $\begin{array}{c}\text { Type } \\
\text { of } \\
\text { openings }\end{array}$ \\
\hline RGWCD 14 & NA04301019BBB & $\mathbf{U}$ & 25.0 & 6.0 & 25.0 & 6.0 & $\mathrm{G}$ & $\mathbf{P}$ \\
\hline RGWCD 15 & NA04201001AAA & $\mathbf{U}$ & 27.0 & 9.0 & 27.0 & 6.0 & G & $\mathbf{P}$ \\
\hline RGWCD 18 & NA04201007CCC & $\mathbf{U}$ & 57.0 & 2.0 & - & 16.0 & $\mathbf{S}$ & $\mathbf{P}$ \\
\hline RGWCD 23 & NA04200936DDD2 & $\mathbf{N}$ & 24.0 & 6.0 & 24.0 & 6.0 & G & $\mathbf{P}$ \\
\hline RGWCD 24A & NA04101002ABA & $\mathbf{U}$ & 35.0 & 10.0 & 35.0 & 6.0 & $S$ & $\mathbf{P}$ \\
\hline RGWCD 27 & NA04001106BBB & $\mathbf{U}$ & 20.0 & -- & - & 6.0 & $S$ & $\mathbf{P}$ \\
\hline RGWCD 41 & NA03901106BBB & $\mathbf{N}$ & 27.0 & 9.0 & 27.0 & 6.0 & G & $\mathbf{P}$ \\
\hline RGWCD 42 & NA04001232BAA & $\mathbf{N}$ & 30.0 & -- & - & 6.0 & $\mathbf{S}$ & -- \\
\hline RGWCD 45A & NA03801202DAD2 & $\mathbf{U}$ & 54.2 & 40.0 & 54.2 & 6.0 & $S$ & $\mathbf{P}$ \\
\hline RGWCD 47 & NA03801103AAA2 & $\mathbf{U}$ & 45.5 & 44.0 & 45.5 & 1.25 & $S$ & $S$ \\
\hline RGWCD 58 & NA03701105AAA & $\mathbf{U}$ & 26.0 & 6.0 & 26.0 & 6.0 & G & $\mathbf{P}$ \\
\hline RGWCD 59A & NA03701101AAA2 & $\mathbf{U}$ & 29.0 & 20.0 & 29.0 & 6.0 & $S$ & $\mathbf{P}$ \\
\hline USBR EW 2U & NA03701113AAA1 & $\mathbf{U}$ & 39.0 & 19.0 & 39.0 & 2.0 & $\mathbf{P}$ & $\mathbf{P}$ \\
\hline USBR EW 8U & NA03701201DDA & $\mathbf{U}$ & 110.0 & 80.0 & 110.0 & 2.0 & $\mathbf{P}$ & $S$ \\
\hline USBR EW 9U & NA03801225ABB 1 & $\mathbf{U}$ & 80.0 & 60.0 & 80.0 & 2.0 & $\mathbf{P}$ & $\mathbf{P}$ \\
\hline USBR EW $11 U$ & NA03801116DDD1 & $\mathbf{U}$ & 39.0 & 19.0 & 39.0 & 2.0 & $\mathbf{P}$ & $\mathbf{P}$ \\
\hline USBR EW 12U & NA03801124CAA & $\mathbf{U}$ & 31.0 & 11.0 & 31.0 & 2.0 & $\mathbf{P}$ & $\mathbf{S}$ \\
\hline USBR EW $14 U$ & NA03801206DAC1 & $\mathbf{U}$ & 36.0 & 16.0 & 36.0 & 2.0 & $\mathbf{P}$ & $\mathbf{S}$ \\
\hline USBR EW 16U & NA03901236DCC1 & $\mathbf{U}$ & 29.0 & 9.0 & 29.0 & 2.0 & $\mathbf{P}$ & $\mathbf{P}$ \\
\hline USBR EW 19U & NA03901218CCD & $\mathbf{U}$ & 35.0 & 15.0 & 35.0 & 2.0 & $\mathbf{P}$ & $\mathbf{S}$ \\
\hline USBR EW 20U & NA03901116AAA1 & $\mathbf{U}$ & 39.0 & 14.0 & 39.0 & 2.0 & $\mathbf{P}$ & $S$ \\
\hline USBR EW $21 U$ & NA03901207CAB3 & $\mathbf{U}$ & 49.0 & 29.0 & 49.0 & 2.0 & $\mathbf{P}$ & $S$ \\
\hline USBR EW 22C & NA03901212CDD2 & C & 168.0 & 148.0 & 168.0 & 2.0 & $\mathbf{P}$ & $\mathbf{P}$ \\
\hline USBR EW 23U & NA03901201AAB1 & $\mathbf{U}$ & 78.0 & 58.0 & 78.0 & 2.0 & $\mathbf{P}$ & $\mathbf{P}$ \\
\hline USBR EW 24U & NA04001233AAA1 & $\mathbf{U}$ & 39.0 & 19.0 & 39.0 & 2.0 & $\mathbf{P}$ & $\mathbf{P}$ \\
\hline USBR EW 26U & NA04001135DCC3 & $\mathbf{U}$ & 39.5 & 19.5 & 39.5 & 2.0 & $\mathbf{P}$ & $S$ \\
\hline USBR EW 32C & NA03901001DDD2 & $\mathrm{C}$ & 113.0 & 93.0 & 113.0 & 4.0 & $\mathbf{P}$ & $\mathbf{P}$ \\
\hline USBR EW 32U & NA03901001DDD1 & $\mathbf{U}$ & 43.0 & 23.0 & 43.0 & 4.0 & $\mathbf{P}$ & $\mathbf{P}$ \\
\hline USBR EW 33C & NA04001024BAA2 & $\mathrm{C}$ & 143.0 & 123.0 & 143.0 & 4.0 & $\mathbf{P}$ & $\mathbf{P}$ \\
\hline USBR EW 33U & NA04001024BAA1 & $\mathbf{U}$ & 43.0 & 23.0 & 43.0 & 4.0 & $\mathbf{P}$ & $\mathbf{P}$ \\
\hline
\end{tabular}

6 Regression Models of Monthly Water-Level Change In and Near the Closed Basin Division of the San Luis Valley, South-Central Colorado 
Table 1. Location and construction data for selected observation wells in the Closed Basin Division study area--Continued

\begin{tabular}{|c|c|c|c|c|c|c|c|c|}
\hline $\begin{array}{c}\text { Well } \\
\text { name } \\
\text { (see pl. } 1 \\
\text { for location) }\end{array}$ & $\begin{array}{l}\text { Land-net } \\
\text { location }\end{array}$ & $\begin{array}{l}\text { Aqulfer- } \\
\text { type } \\
\text { code }\end{array}$ & $\begin{array}{l}\text { Well } \\
\text { depth } \\
\text { (foet) }\end{array}$ & $\begin{array}{l}\text { Depth } \\
\text { to } \\
\text { top of } \\
\text { open } \\
\text { Interval } \\
\text { (foet) }\end{array}$ & $\begin{array}{l}\text { Depth } \\
\text { to } \\
\text { bottom of } \\
\text { open } \\
\text { Interval } \\
\text { (feet) }\end{array}$ & $\begin{array}{c}\text { Dlameter } \\
\text { of } \\
\text { open } \\
\text { Interval } \\
\text { (Inches) }\end{array}$ & $\begin{array}{l}\text { Casing } \\
\text { material }\end{array}$ & $\begin{array}{c}\text { Type } \\
\text { of } \\
\text { openings }\end{array}$ \\
\hline USBR EW 34C & NA04001016DDC1 & C & 113.0 & 93.0 & 113.0 & 4.0 & $\mathbf{P}$ & $\mathbf{P}$ \\
\hline USBR EW 34U & NA04001016DDC & U & 43.0 & 23.0 & 43.0 & 4.0 & $\mathbf{P}$ & $\mathbf{P}$ \\
\hline USBR EW 35C & NA04001010AAA2 & C & 123.0 & 103.0 & 123.0 & 4.0 & $\mathbf{P}$ & $\mathbf{P}$ \\
\hline USBR EW $35 U$ & NA04001010AAA1 & $\mathrm{U}$ & 43.0 & 23.0 & 43.0 & 4.0 & $\mathbf{P}$ & $\mathbf{P}$ \\
\hline USBR EW 39C & NA04101015CCC2 & C & 128.0 & 113.0 & 128.0 & 4.0 & $\mathbf{P}$ & $\mathbf{P}$ \\
\hline USBR EW $39 U$ & NA04101015CCC1 & $\mathrm{U}$ & 43.0 & 23.0 & 43.0 & 4.0 & $\mathbf{P}$ & $\mathbf{P}$ \\
\hline USBR EW $40 C$ & NA04101032ABB2 & C & 125.0 & 115.0 & 125.0 & 4.0 & $\mathbf{P}$ & $\mathbf{P}$ \\
\hline USBR EW 40U & NA04101032ABB1 & $\mathrm{U}$ & 43.0 & 24.0 & 43.0 & 4.0 & $\mathbf{P}$ & $\mathbf{P}$ \\
\hline USBR PW 1-7 & NA03701101CCD1 & C & 109.0 & 99.0 & 109.0 & 4.0 & $\mathbf{P}$ & $s$ \\
\hline USBR PW 2-4 & $\mathrm{NA} 03901224 \mathrm{CCCl}$ & C & 138.0 & 127.0 & 137.0 & 4.0 & $\mathbf{P}$ & $s$ \\
\hline USBR PW 2-5 & NA03801202CCC1 & C & 124.0 & 114.0 & 124.0 & 4.0 & $\mathbf{P}$ & S \\
\hline USBR PW 4-1 & NA04201017ADC1 & C & 107.0 & 97.0 & 107.0 & 4.0 & $\mathbf{P}$ & $s$ \\
\hline USBR PW 4-4 & NA04101016BBB1 & C & 124.0 & 114.0 & 124.0 & 4.0 & $\mathbf{P}$ & $s$ \\
\hline USBR PW 4-5 & NA04101013ABD1 & U & 105.0 & 95.0 & 105.0 & 4.0 & $\mathbf{P}$ & s \\
\hline USBR PW 5-2 & NA04200924DAD1 & $\mathrm{U}$ & 105.0 & 95.0 & 105.0 & 4.0 & $\mathbf{P}$ & $s$ \\
\hline USBR SNIPPY & NA03801216DDB1 & $\mathrm{U}$ & 72.0 & 10.0 & 72.0 & 16.0 & S & $\mathbf{P}$ \\
\hline
\end{tabular}



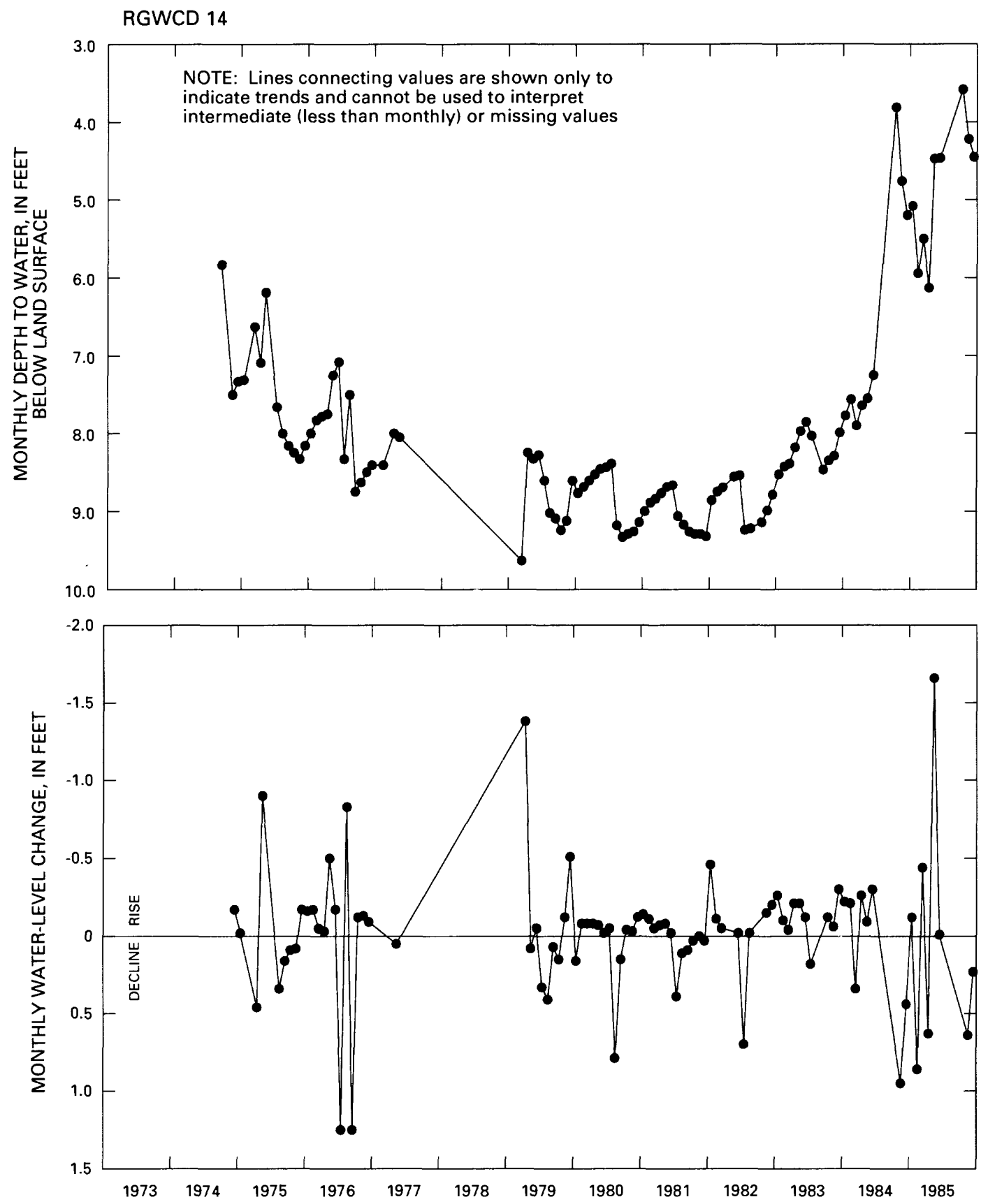

Figure 2. Monthly depth to water and monthly water-level change at observation well RGWCD 14, closed basin of San Luis Valley. 

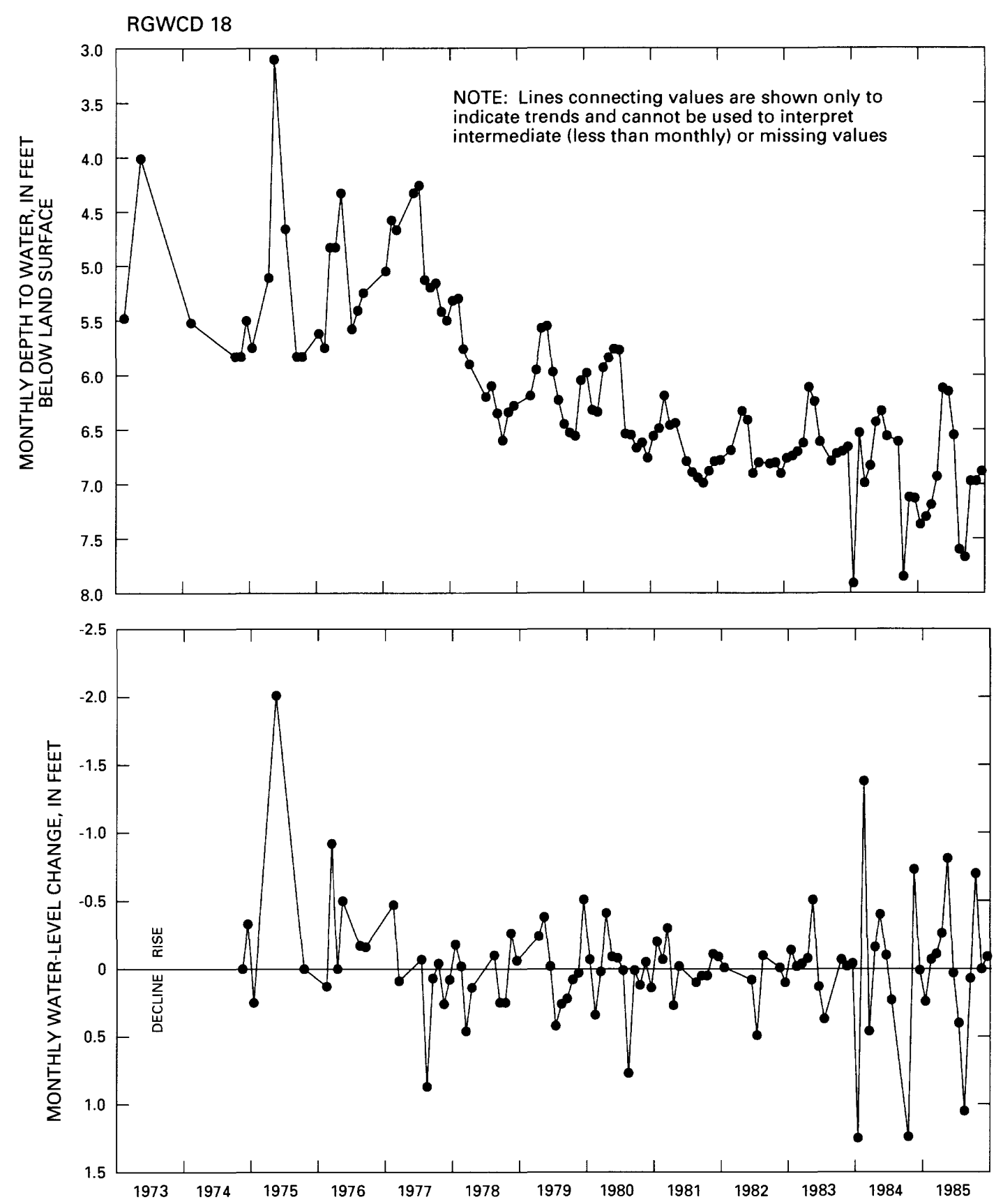

Figure 3. Monthly depth to water and monthly water-level change at observation well RGWCD 18, closed basin of San Luis Valley. 

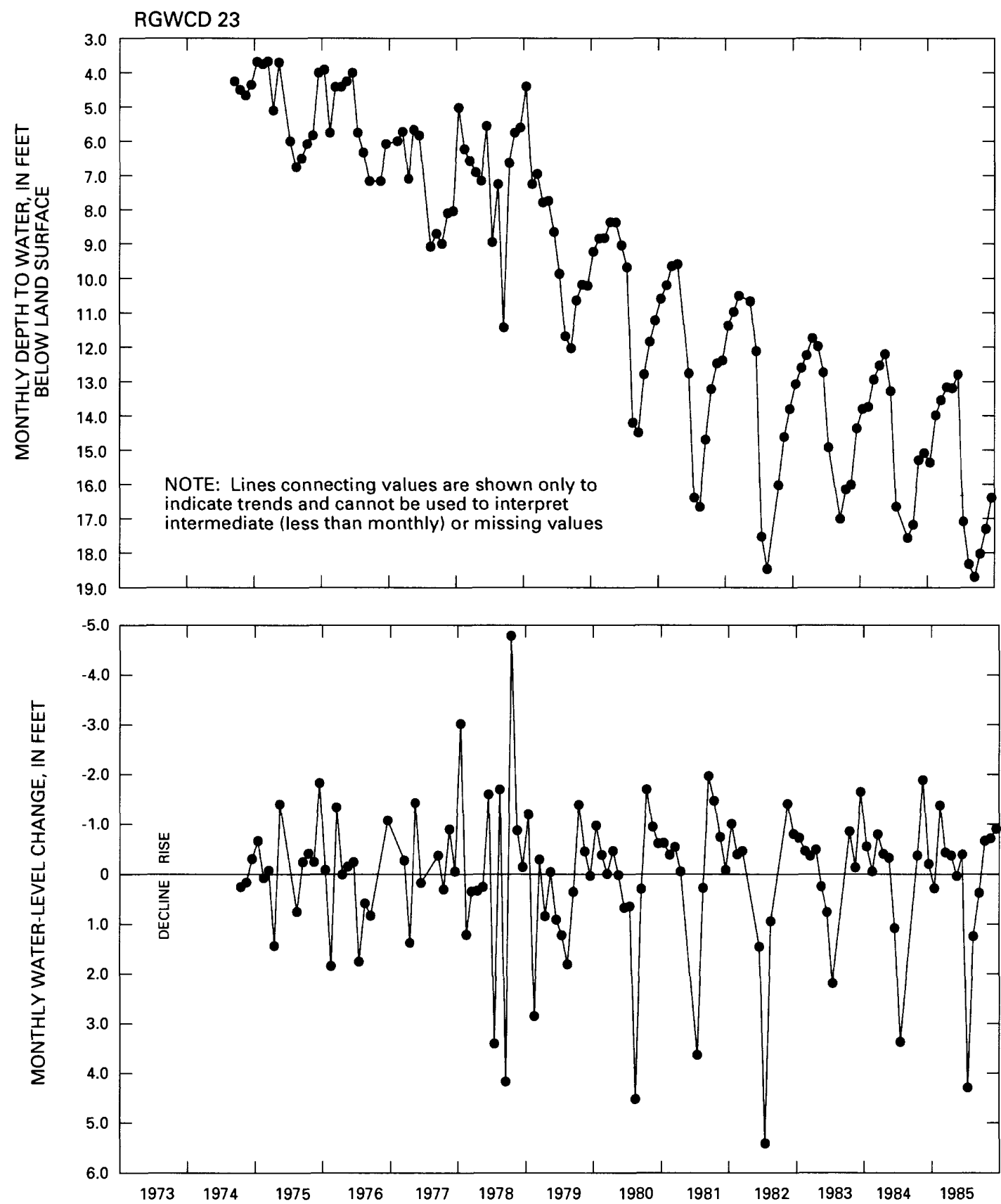

Figure 4. Monthly depth to water and monthly water-level change at observation well RGWCD 23, closed basin of San Luis Valley. 

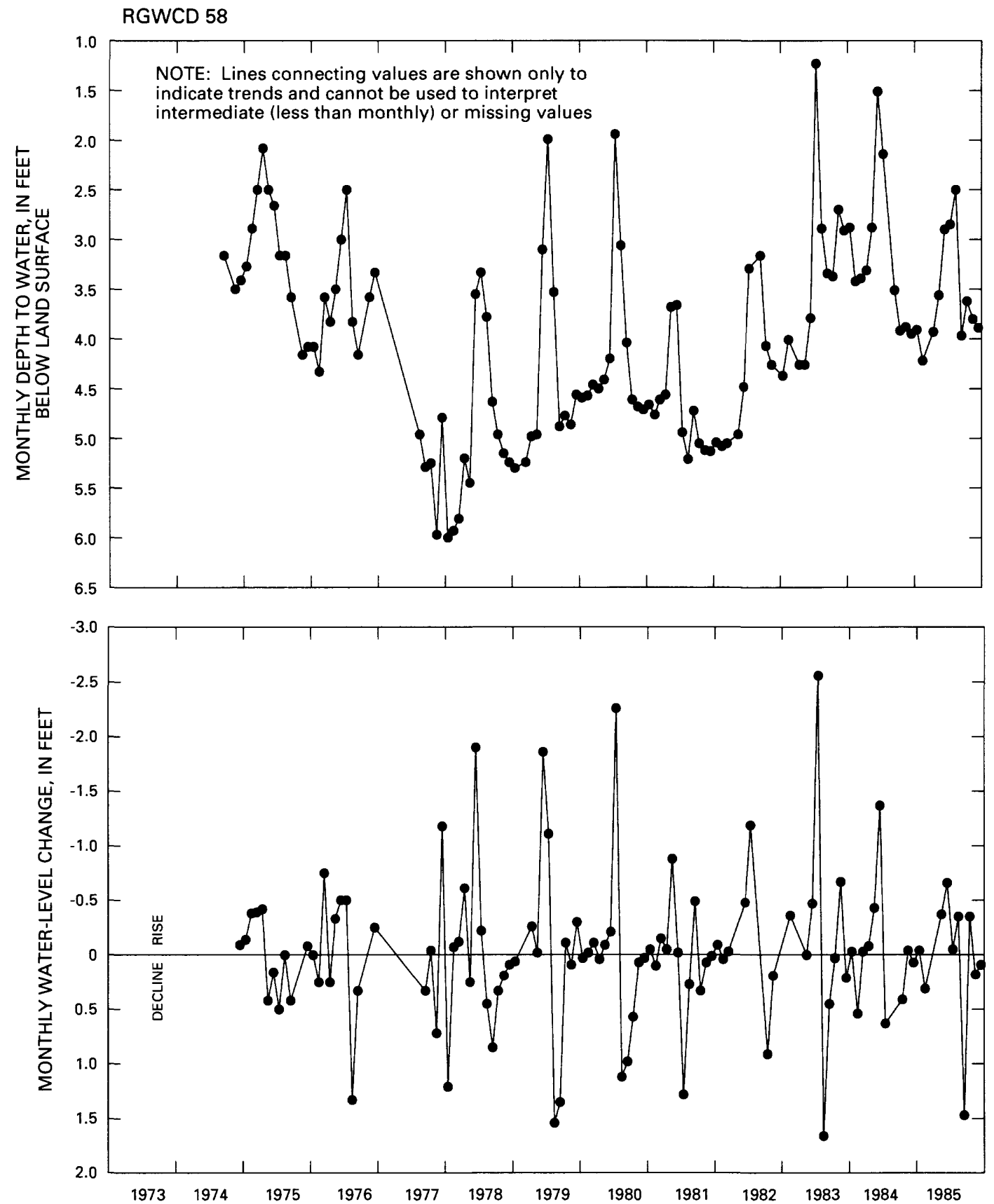

Flgure 5. Monthly depth to water and monthly water-level change at observation well RGWCD 58, closed basin of San Luis Valley. 

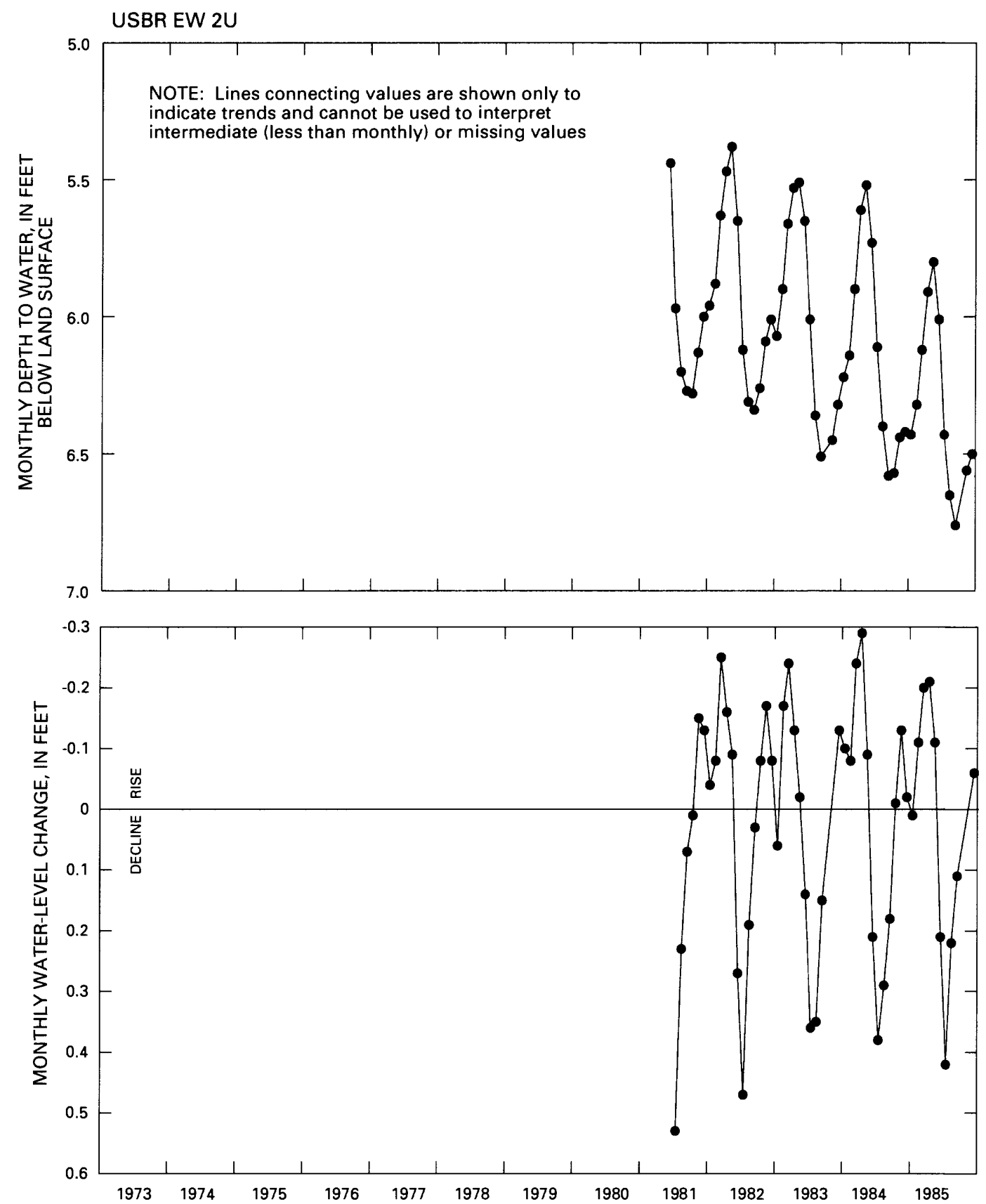

Figure 6. Monthly depth to water and monthly water-level change at observation well USBR EW $2 U$, closed basin of San Luis Valley. 

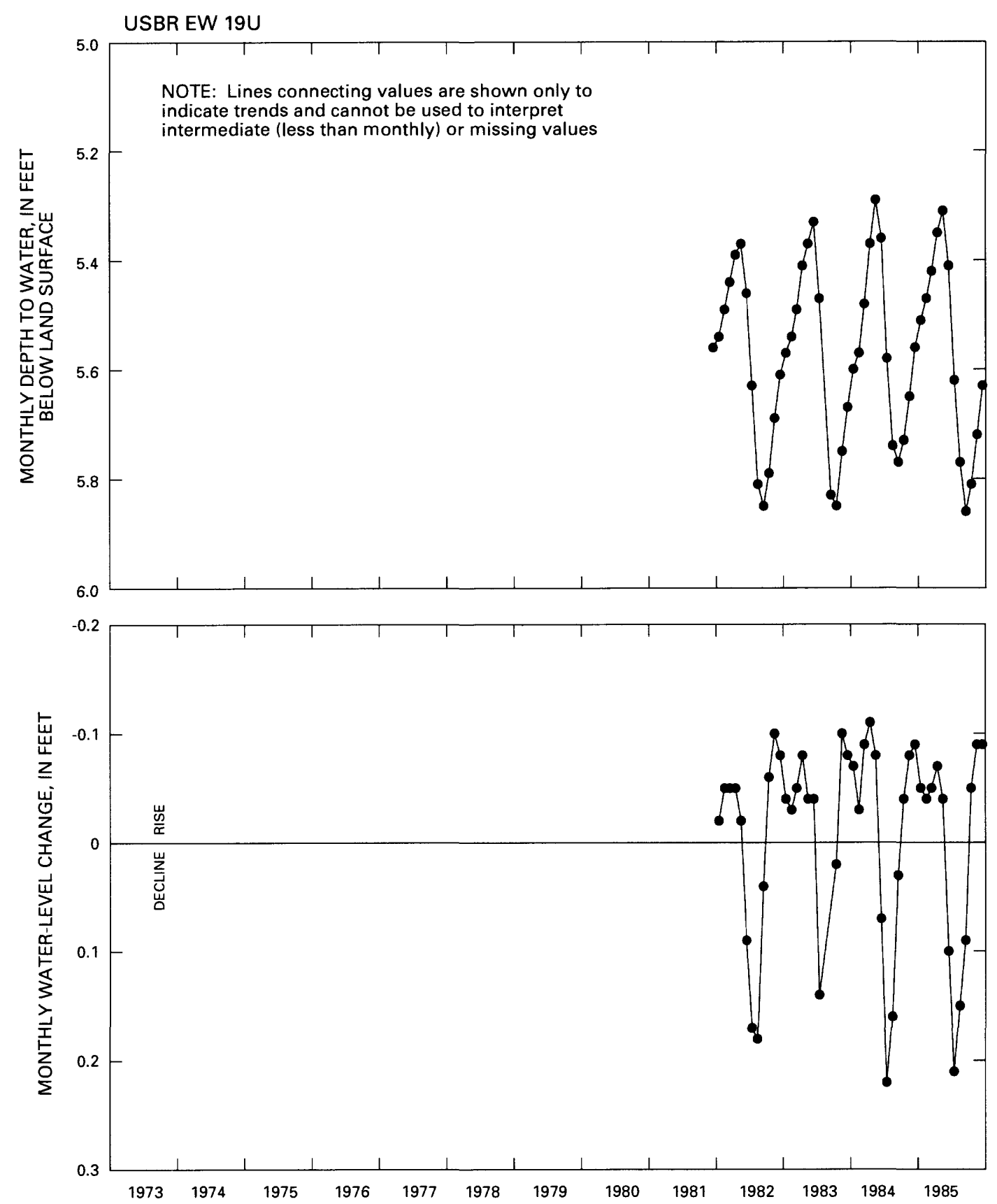

Figure 7. Monthly depth to water and monthly water-level change at observation well USBR EW 19U, closed basin of San Luis Valley. 

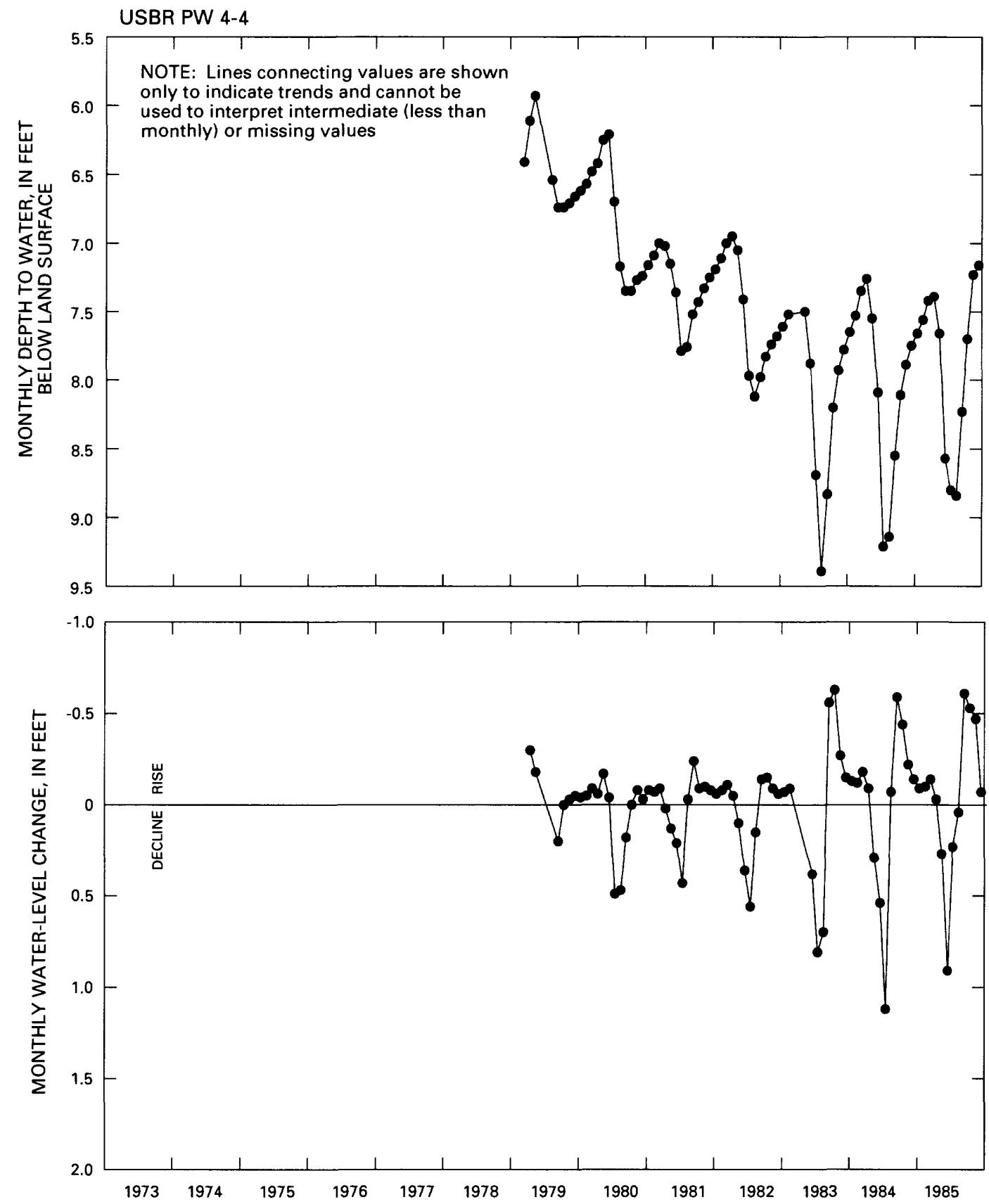

Figure 8. Monthly depth to water and monthly water-level change at observation well USBR PW 4-4, closed basin of San Luis Valley. 

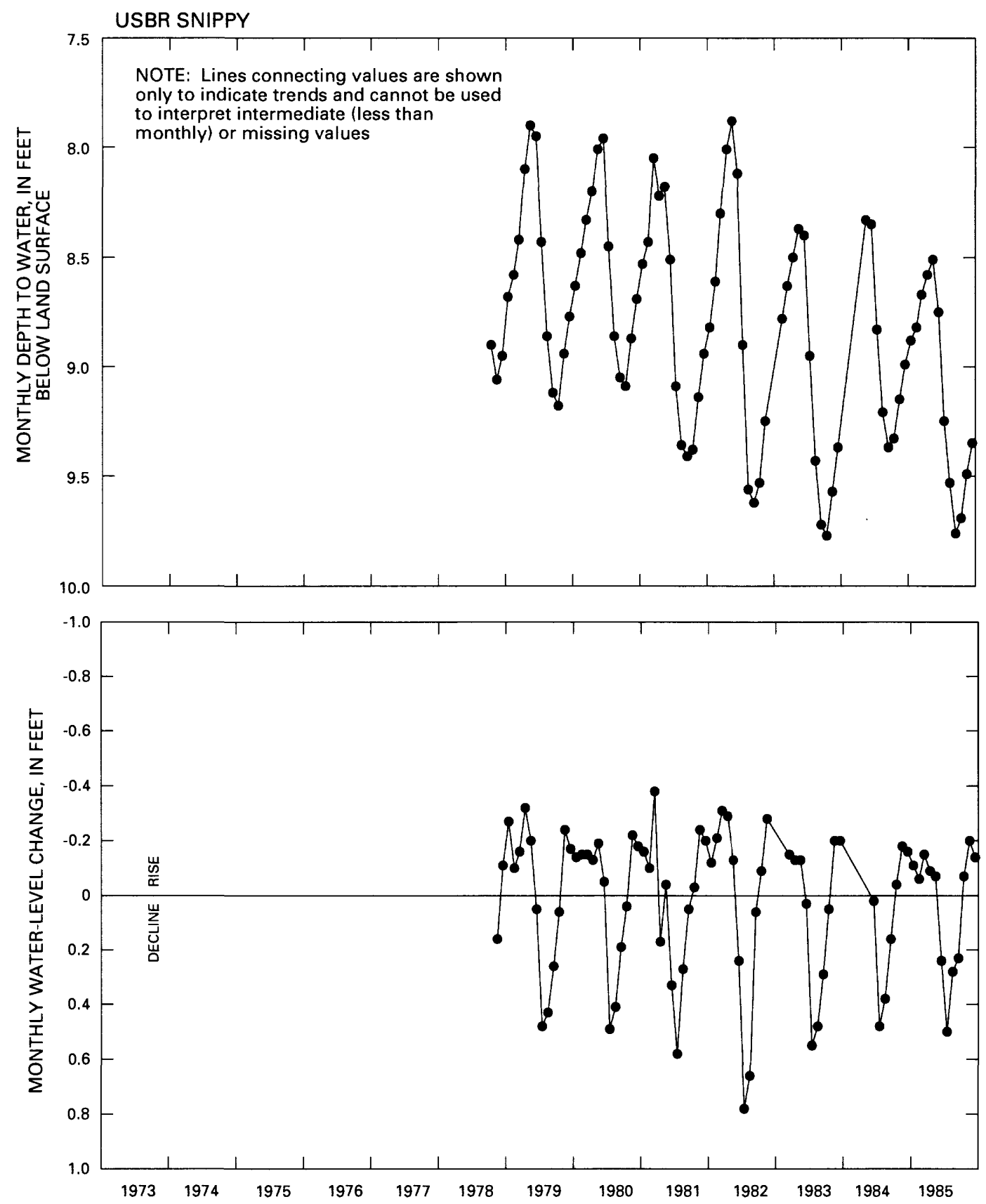

Figure 9. Monthly depth to water and monthly water-level change at observation well USBR SNIPPY, closed basin of San Luis Valley. 
Table 2. Summary statistics of monthly water-level changes for selected observation wells in the Closed Basin Division study area, 1973-85

[Negative values for mean monthly water-level change and minimum water-level change indicate water-level rises; positive values indicate water-level declines. Well names of wells completed in a confined aquifer are preceded by an asterisk, ${ }^{*}$ ]

\begin{tabular}{|c|c|c|c|c|c|c|}
\hline $\begin{array}{c}\text { Well } \\
\text { name }\end{array}$ & $\begin{array}{c}\text { Number } \\
\text { of } \\
\text { observations }\end{array}$ & $\begin{array}{c}\text { Number } \\
\text { of } \\
\text { missing } \\
\text { observations }\end{array}$ & $\begin{array}{l}\text { Mean } \\
\text { (feot) }\end{array}$ & $\begin{array}{l}\text { Standard } \\
\text { deviation } \\
\text { (feet) }\end{array}$ & $\begin{array}{l}\text { Minimum } \\
\text { value } \\
\text { (feet) }\end{array}$ & $\begin{array}{l}\text { Maximum } \\
\text { value } \\
\text { (foet) }\end{array}$ \\
\hline RGWCD 14 & 89 & 67 & -0.01 & 0.426 & -1.66 & 1.25 \\
\hline RGWCD 15 & 98 & 58 & -.001 & .549 & -2.74 & 1.65 \\
\hline RGWCD 18 & 97 & 59 & -.019 & .434 & -2.01 & 1.25 \\
\hline RGWCD 23 & 117 & 39 & .024 & 1.461 & -4.79 & 5.41 \\
\hline RGWCD 24A & 62 & 94 & -.010 & .400 & -1.02 & 1.98 \\
\hline RGWCD 27 & 101 & 55 & -.034 & .440 & -1.29 & 1.66 \\
\hline RGWCD 41 & 102 & 54 & -.125 & 1.181 & -4.97 & 2.45 \\
\hline RGWCD 42 & 114 & 42 & -.030 & .422 & -1.70 & 1.34 \\
\hline RGWCD 45A & 61 & 95 & -.004 & .234 & -.79 & .83 \\
\hline RGWCD 47 & 63 & 93 & -.002 & .111 & -.24 & .36 \\
\hline RGWCD 58 & 107 & 49 & -.022 & .698 & -2.56 & 1.66 \\
\hline RGWCD 59A & 58 & 98 & -.002 & .519 & -.93 & 1.61 \\
\hline USBR EW $2 U$ & 50 & 106 & .026 & .208 & -.29 & .53 \\
\hline USBR EW 8U & 40 & 116 & .048 & .056 & -.13 & .19 \\
\hline USBR EW 9U & 31 & 125 & .038 & .080 & -.21 & .22 \\
\hline USBR EW $11 U$ & 30 & 126 & -.071 & .533 & -1.71 & .61 \\
\hline USBR EW $12 U$ & 29 & 127 & -.038 & .219 & -.54 & .57 \\
\hline USBR EW $14 U$ & 37 & 119 & -.027 & .050 & -.14 & .09 \\
\hline USBR EW $16 U$ & 36 & 120 & -.017 & .298 & -.76 & .79 \\
\hline USBR EW 19U & 46 & 110 & -.006 & .093 & -.11 & .22 \\
\hline USBR EW 20U & 36 & 120 & -.029 & .111 & -.33 & .23 \\
\hline USBR EW $21 U$ & 36 & 120 & .027 & .206 & -.21 & .43 \\
\hline *USBR EW 22C & 24 & 132 & -.049 & .309 & -1.10 & .42 \\
\hline USBR EW 23U & 34 & 122 & -.064 & .374 & -1.27 & 1.10 \\
\hline USBR EW $24 U$ & 29 & 127 & .027 & .177 & -.21 & .34 \\
\hline USBR EW 26U & 48 & 108 & -.036 & .074 & -.25 & .11 \\
\hline *USBR EW 32C & 28 & 128 & -.036 & .463 & -.60 & 1.55 \\
\hline USBR EW 32U & 23 & 133 & .062 & .592 & -1.30 & 1.40 \\
\hline *USBR EW 33C & 22 & 134 & -.012 & 2.123 & -4.17 & 5.29 \\
\hline USBR EW 33U & 30 & 126 & -.120 & .216 & -.64 & .41 \\
\hline
\end{tabular}


Table 2. Summary statistics of monthly water-level changes for selected observation wells in the Closed Basin Division study area, 1973-85--Continued

\begin{tabular}{ccccccc}
\hline $\begin{array}{c}\text { Well } \\
\text { name }\end{array}$ & $\begin{array}{c}\text { Number } \\
\text { of } \\
\text { observations }\end{array}$ & $\begin{array}{c}\text { Number } \\
\text { of } \\
\text { missing } \\
\text { observatlons }\end{array}$ & $\begin{array}{c}\text { Mean } \\
\text { (foet) }\end{array}$ & $\begin{array}{c}\text { Standard } \\
\text { deviation } \\
\text { (foet) }\end{array}$ & $\begin{array}{c}\text { Minimum } \\
\text { value } \\
\text { (foet) }\end{array}$ & $\begin{array}{c}\text { Maximum } \\
\text { value } \\
\text { (feet) }\end{array}$ \\
\hline *USBR EW 34C & 24 & 132 & 0.241 & 3.751 & -9.44 & 9.28 \\
USBR EW 34U & 33 & 123 & .002 & .206 & -.22 & .44 \\
*USBR EW 35C & 22 & 134 & -.588 & 1.727 & -5.38 & 1.60 \\
USBR EW 35U & 20 & 136 & -.027 & .402 & -.75 & 1.09 \\
*USBR EW 39C & 24 & 132 & -.026 & .173 & -.28 & .40 \\
& & & & & & \\
USBR EW 39U & 22 & 134 & -.007 & .103 & -.16 & .25 \\
*USBR EW 40C & 30 & 126 & -.158 & .381 & -.92 & .64 \\
USBR EW 40U & 27 & 129 & -.024 & .223 & -.41 & .56 \\
*USBR PW 1-7 & 36 & 120 & .016 & .147 & -.21 & .39 \\
*USBR PW 2-4 & 64 & 92 & .003 & .184 & -.20 & .49 \\
& & & & & & .39 \\
*USBR PW 2-5 & 42 & 114 & -.004 & .087 & -.11 & .35 \\
*USBR PW 4-1 & 65 & 91 & .009 & .200 & -.51 & .47 \\
*USBR PW 4-4 & 75 & 81 & .002 & .327 & -.63 & 1.12 \\
USBR PW 4-5 & 35 & 121 & -.019 & .272 & -.46 & .44 \\
USBR PW 5-2 & 56 & 100 & .090 & .372 & -.61 & .96 \\
USBR SNIPPY & 78 & 78 & .025 & .268 & -.38 & .78 \\
\hline
\end{tabular}




\section{REGRESSION MODELS OF WATER- LEVEL CHANGE}

Regression models of monthly water-level change were developed for each of the 46 selected observation wells. Regression methods, rather than deterministic methods, were used to model water-level change because rates and spatial distribution of recharge and discharge, processes that strongly affect water levels in the closed basin, are not well known. In addition, regression models do not require prior knowledge of the distribution of the hydraulic and storage characteristics and boundary conditions of the aquifer system. Numerical and analog models, which previously have been used to simulate ground-water flow in the San Luis Valley (Emery, 1970; Emery and others, 1975; Huntley, 1979; Hearne and Dewey, 1988; Leonard and Watts, 1989), were designed to simulate average water-level change for relatively large areas, and they generally are not sufficiently detailed to predict water-level change at specific points (observation wells).

\section{Linear Regression and Predictor Variables}

Simple-linear regression models are based on a statistical-linear relation between a response variable and one predictor variable. A mathematical expression of a simple-linear regression equation is given by Montgomery and Peck (1982, p. 9) as:

$$
y_{i}=B_{0}+B_{1} x_{1 i}+e_{i}, i=1,2, \ldots, n
$$

where

$y_{i}=$ the value of the response variable for the $\mathrm{i}^{\text {th }}$ observation,

$B_{0}$ and $B_{1}$ are regression parameters: $B_{0}$ is the intercept and $B_{1}$ is the slope of the regression line,

$x_{1 i}=$ the value of the predictor variable for the $\mathrm{i}^{\text {th }}$ observation,

$\mathrm{e}_{\mathbf{i}}=$ an error term, and

$\mathrm{n}$ = the number of observations.

The basic assumptions of linear regression are: (1) $e_{i}$ is a random error with mean zero and unknown, but constant, variance; and (2) $e_{i}$ and $e_{j}, i \neq j$, are uncorrelated.

Multiple-linear regression models (eq. 2) are similar to simple-linear regression models (eq. 1), except that multiple-linear regression models include more than one predictor variable. A mathematical expression of a multiple-linear regression equation is given by Montgomery and Peck (1982, p. 110) as:

$$
\begin{aligned}
y_{i} & =B_{0}+B_{1} x_{1 i}+B_{2} x_{2 i}+\ldots+B_{k} x_{k i}+e_{i}, \\
i & =1,2, \ldots, n
\end{aligned}
$$

where

$B_{2} \ldots B_{k}$ are regression parameters for the $x_{2 i} \ldots x_{k i}$, the multiple predictor variables.

The predictor variables considered in the regression models of water-level change are: (1) Elapsed time (T), in months, where $T=1$ for January 1973;

(2) a cosine function $\left(X_{c}\right)$ with an annual period;

(3) a sine function $\left(X_{s}\right)$ with an annual period;

(4) monthly precipitation (PP), in inches; (5) monthly mean air temperature (TA), in degrees Fahrenheit;

(6) monthly mean discharge of Saguache Creek near Saguache (RO), in cubic feet per second; (7) monthly mean depletion of the Rio Grande between Del Norte and Trinchera Creek (SW), in cubic feet per second; and (8) monthly electric power use for agricultural purposes by customers of the San Luis Valley REC (GW), in gigawatt-hours. The variation of the predictor variables PP, TA, RO, SW, and GW was assumed to be related to the variation of ground-water recharge and discharge rates; however, data are not available to verify the validity of this assumption.

Selection of the "best" subset of predictor variables for a multiple-linear regression model is a complex task because of two conflicting objectives of regression models, because of collinearity of predictor variables, and because of serial correlation of the response and predictor variables. One objective of regression analysis is to include as many predictor variables as possible so that their information content can affect the prediction of the response variable. A conflicting objective of regression analysis is to include as few predictor variables as possible because the variance of the predicted value increases as the number of predictor variables increases.

Collinearity occurs when predictor variables are highly correlated, and it may adversely affect the leastsquares fit of the regression model. Strong collinearity between predictor variables results in large variances and covariances for the least-squares estimates of the regression parameters, and it also may produce parameter estimates that are too large in absolute value (Montgomery and Peck, 1982). Collinearity also may cause problems in using regression models for prediction if future values of the predictor variables are outside the range of the joint space of the predictor variables that were used to generate the regression model. A primary cause of collinearity in the predictor variables that were used in this analysis is assumed to be the seasonal effect of climate. In an attempt to 
isolate the seasonal effect on water-level change from other causes of variability and to decrease variance in predictor variables due to seasonal fluctuation, the regression analysis is approached in two stages. In the first stage, variables defined by measured data, which hereinafter are called first-stage predictor variables, are regressed with annual-period harmonic functions of time, using a monthly time increment. Seasonality in the first-stage predictor variables is evaluated by regression of the first-stage predictor variables with a cosine function of time $\left[X_{c}=\operatorname{cosine}(2 \pi \mathrm{m} / 12)\right.$, where $m$ is an integer between 1 and 12 corresponding to the month of the year] and a sine function $\left[\mathrm{X}_{\mathrm{s}}=\operatorname{sine}(2 \pi \mathrm{m} / 12)\right]$. For each measured value, a firststage residual is computed as the difference between the measured value and the value predicted using the harmonic regression model. In the second stage, the first-stage residuals are used as predictor variables in a regression analysis to predict water-level change in specific wells. In addition to the first-stage residuals, the second-stage regression analysis includes the annual-period harmonic functions $\left(X_{c}\right.$ and $\left.X_{s}\right)$ and elapsed time (T) as predictor variables. Predictor variables used in the second stage of the analysis hereinafter are called second-stage predictor variables. A second-stage residual is defined as the difference between a measured value of water-level change in a well and the value predicted using the second-stage regression equation developed for that well.

\section{Harmonic Variation of Variables Related to Recharge and Discharge}

Variation in rates of natural recharge and discharge and in water-use practices causes water levels to fluctuate. Since 1950, the rates of recharge and discharge in the closed basin have varied primarily as a result of changes in water-use practices and variation of surface-water supply. Withdrawals of ground water for irrigation increased during the 1950's, and many irrigation systems were converted from flood and subirrigation to sprinkler irrigation during the 1970's and 1980's (Davis Engineering Services, Inc., 1983).

Ground-water recharge to, and discharge from, the aquifers in the closed basin are affected by climate, deep percolation of excess irrigation water, surfacewater runoff into the closed basin, vertical flow among the unconfined and confined aquifers, and groundwater underflow. Variations in the rates of recharge and discharge are assumed to be related to variations in precipitation, evapotranspiration, streamflow depletion of the Rio Grande between Del Norte and Trinchera Creek, electrical energy use for irrigation, and surface water (runoff) from a part of the contributing drainage area. These data, except for evapotranspiration rates, are collected on a routine basis by Federal and State agencies and by utility companies. Vertical flow among the unconfined and confined aquifers and ground-water underflow are proportional to hydraulic gradients and, therefore, are dependent on water levels. Consequently, vertical flow and underflow were not used as predictor variables in the regression models. Because the response variables (water-level change) were monthly mean or mid-month values, the predictor variables for the previous month were assumed to cause the water-level change. Therefore, the predictor variables used in the regression equations were lagged 1 month.

\section{Precipitation and Air Temperature}

Precipitation in the closed basin is less than potential evapotranspiration. Average annual precipitation in the closed basin for the period 1973-85 was about $0.7 \mathrm{ft}$, and average seasonal (April-October) pan evaporation was an estimated $4.5 \mathrm{ft}$. Monthly precipitation for the closed basin (fig. 10) is estimated as the average of monthly precipitation at four weather stations in or near the closed basin (pl. 1). The four weather stations (Alamosa WSO AP-station 0130; Center 4 SSW - station 1458; Del Norte-station 2184; and Saguache-station 7337) were selected based on completeness of record and proximity to the study area. The monthly precipitation values, lagged by 1 month, are plotted as point values in figure 10A. The line plotted in figure $10 \mathrm{~A}$ is a seasonal harmonic model of monthly precipitation. The regression equation for the harmonic model is:

$$
\overline{\mathrm{PP}}_{\mathrm{m}}=0.666-0.133 \mathrm{X}_{\mathrm{cm}}-0.398 \mathrm{X}_{\mathrm{sm}},
$$

where

$$
\begin{aligned}
\overline{\mathrm{PP}}_{\mathrm{m}}= & \text { the predicted value of monthly precipi- } \\
& \text { tation, in inches; } \\
\mathrm{X}_{\mathrm{cm}}= & \text { cosine }(2 \pi \mathrm{m} / 12) ; \\
\mathrm{m}= & \text { the number of the month (January }=1, \\
& \text { February }=2, \ldots, \text { December }=12) ; \text { and } \\
\mathrm{X}_{\mathrm{sm}}= & \text { sine }(2 \pi \mathrm{m} / 12) .
\end{aligned}
$$

The point values plotted in figure 10B are the residual errors, the difference between the measured precipitation values and the value predicted from the harmonic model $\left(R_{P P}=P_{i}-\overline{P P}_{m}\right)$.

Potential evapotranspiration cannot be measured directly, but it generally is assumed to be proportional to evaporation from a class-A pan. Pan evaporation is measured seasonally (April through September or October) at Alamosa WSO AP, and it can be assumed to be zero during the colder months (November through 

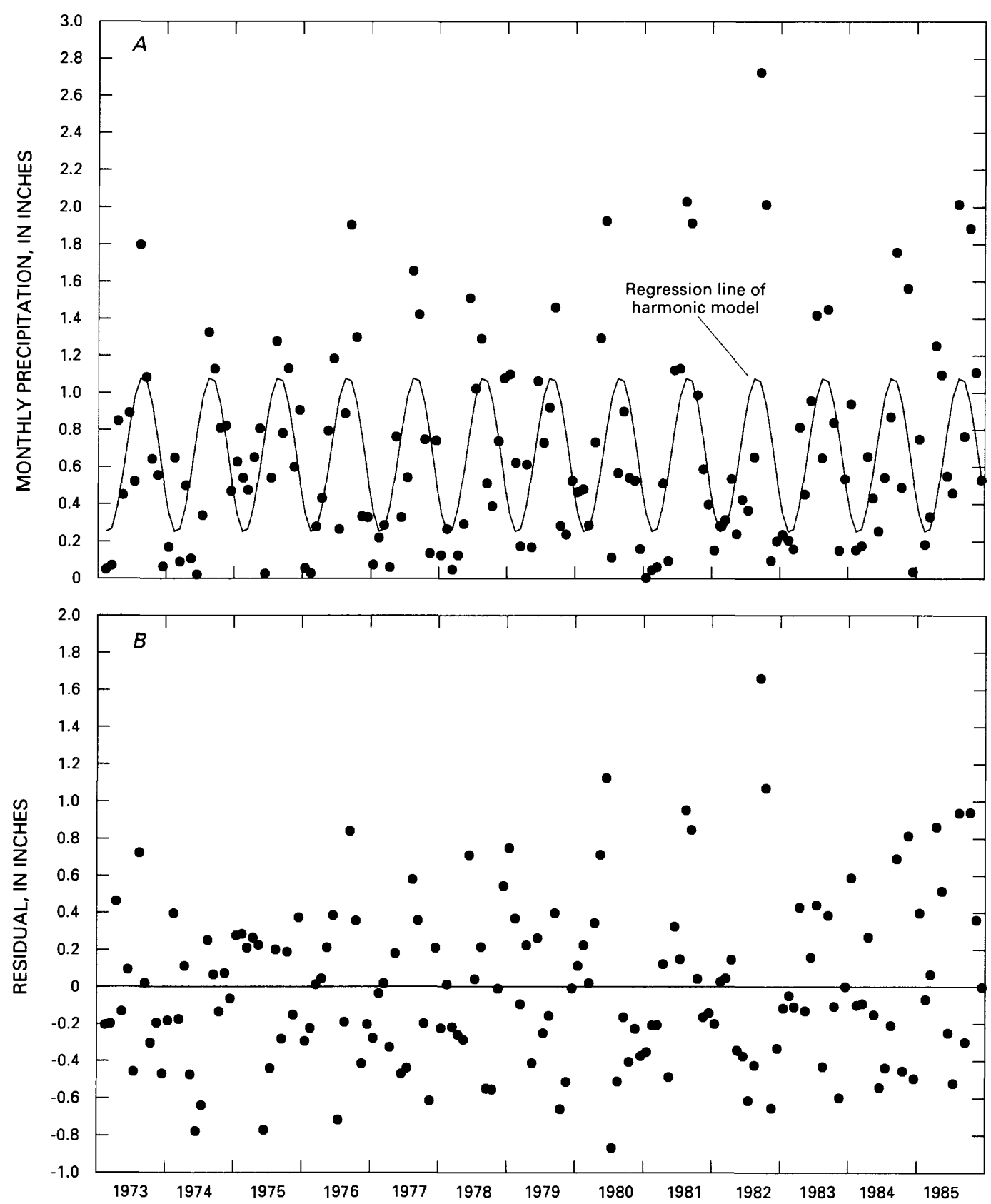

Figure 10. (A) Monthly precipitation in the closed basin of San Luis Valley and a harmonic model of monthly precipitation; and (B) the residual, 1973-85. 
March). However, missing values in the 1973-85 climatological record preclude the use of pan evaporation as a predictor variable. An analysis of monthly mean air temperature and monthly pan evaporation at Alamosa WSO AP was done to determine the degree of correlation between the two variables. Monthly pan evaporation was assumed to be zero during the months November through March. For the period 1973 through 1985, mean temperature is available for all 156 months, and (non-zero) pan evaporation values are available for 51 months. Assumed values of zero for 65 months resulted in a total of 116 months for which pan evaporation values were included in the analysis. For this data set, the Pearson correlation coefficient for correlation between monthly mean air temperature and monthly pan evaporation is $\mathbf{0 . 9 0}$. Because of the large correlation of monthly mean air temperature and the monthly pan evaporation, monthly mean air temperature was assumed to be directly related to potential evapotranspiration; therefore, evapotranspiration was not used as a predictor variable. Monthly mean air temperature, lagged 1 month, is shown as point values in figure 11A, and a seasonal harmonic model of monthly mean air temperature is shown as a solid line. The linear regression model for monthly mean air temperature with the harmonic functions is:

$$
\overline{\mathrm{TA}}_{\mathrm{m}}=40.91-20.339 \mathrm{X}_{\mathrm{cm}}-12.627 \mathrm{X}_{\mathrm{sm}},
$$

where

$\overline{\mathrm{TA}}_{\mathrm{m}}$ is the predicted monthly mean air temperature at Alamosa WSO AP, in degrees Fahrenheit, for month $\mathrm{m}$, and $\mathrm{X}_{\mathrm{cm}}$ and $\mathrm{X}_{\mathrm{sm}}$ are as previously defined. The regression model is used to predict the monthly mean air temperature. The residual values, the differences between measured monthly mean air temperature and the values predicted from the harmonic model $\left(\mathrm{RTA}_{\mathrm{i}}=\mathrm{TA}_{\mathrm{i}}-\overline{\mathrm{TA}}_{\mathrm{m}}\right)$, are assumed to be the random component of air temperature and are shown in figure 11B. The close fit of the harmonic model to monthly mean air temperature indicates that monthly mean air temperature varies little from the seasonal harmonic, except in some extremely cold winter months.

\section{Discharge of Saguache Creek}

Runoff from the mountains into the closed basin was estimated to average $266,000 \mathrm{acre}-\mathrm{ft} / \mathrm{yr}$ during 1924-69 (Emery and others, 1973, pl. 1). Of this amount, about 47,000 acre-ft/yr, or about 18 percent, was estimated to have come from Saguache Creek, which is measured at gaging station 08227000 near Saguache, Colo. Many of the smaller streams that flow into the closed basin either are not measured or have incomplete discharge records for the 1973-85 period. Monthly mean discharge of Saguache Creek near Saguache (fig. 12) is assumed to be proportional to runoff into the closed basin as a whole. Mean annual discharge of Saguache Creek near Saguache was 44,400 acre-ft for calendar years 1973-85, and annual discharge ranged from 19,700 acre-ft in 1977 to 73,800 acre-ft in 1984 . Runoff from the mountains is seasonal, and peak runoff, which principally is caused by snowmelt, generally occurs in May, June, or July. Runoff generally infiltrates into the valley-fill deposits within a few miles after entering the closed basin (Huntley, 1979, p. 1217), but runoff occasionally does reach the topographic low of the closed basin. In years when runoff does reach the topographic low, large areas are inundated until the water evaporates or infiltrates into the ground. Point values in figure $12 A$ are the monthly mean discharge of Saguache Creek, lagged 1 month. The solid line in figure 12A is predicted from linear regression of monthly mean discharge of Saguache Creek, lagged 1 month, with the harmonic functions of time. The regression model for monthly mean discharge of Saguache Creek near Saguache is:

$$
\overline{\mathrm{RO}}_{\mathrm{m}}=61.194-42.869 \mathrm{X}_{\mathrm{cm}}-29.224 \mathrm{X}_{\mathrm{sm}} \text {, }
$$

where

$\overline{\mathrm{RO}}_{\mathrm{m}}$ is the predicted monthly mean discharge, in cubic feet per second, for month ${ }_{m}$, and $X_{\mathrm{cm}}$ and $X_{\mathrm{sm}}$ are as previously defined. The residual values are assumed to be the random component of runoff into the closed basin. The point values in figure $12 \mathrm{~B}$ represent the residual differences between measured values and the values predicted from the seasonal harmonic model $\left(\mathrm{RRO}_{\mathrm{i}}=\mathrm{RO}_{\mathrm{i}}-\overline{\mathrm{RO}}_{\mathrm{m}}\right)$.

\section{Streamflow Depletion of the Rio Grande Between Del Norte and Trinchera Creek}

Surface water diverted from the Rio Grande was the primary source of irrigation water in the closed basin prior to 1950 . Estimated annual volume of surface water diverted in the San Luis Valley, which includes the closed basin for the period 1940-79, was 500,000 acre-ft in 1977 and was more than $1,600,000$ acre-ft in 1941, 1952, 1957, and 1965 (Emery and others, 1972, table 10; Crouch, 1985, sheet 1). The average annual surface-water diversion for the period 1940-79 was about 1,107,000 acre-ft. Huntley (1979, table 2, p. 1200) estimated annual surface-water diversions into the closed basin to be 

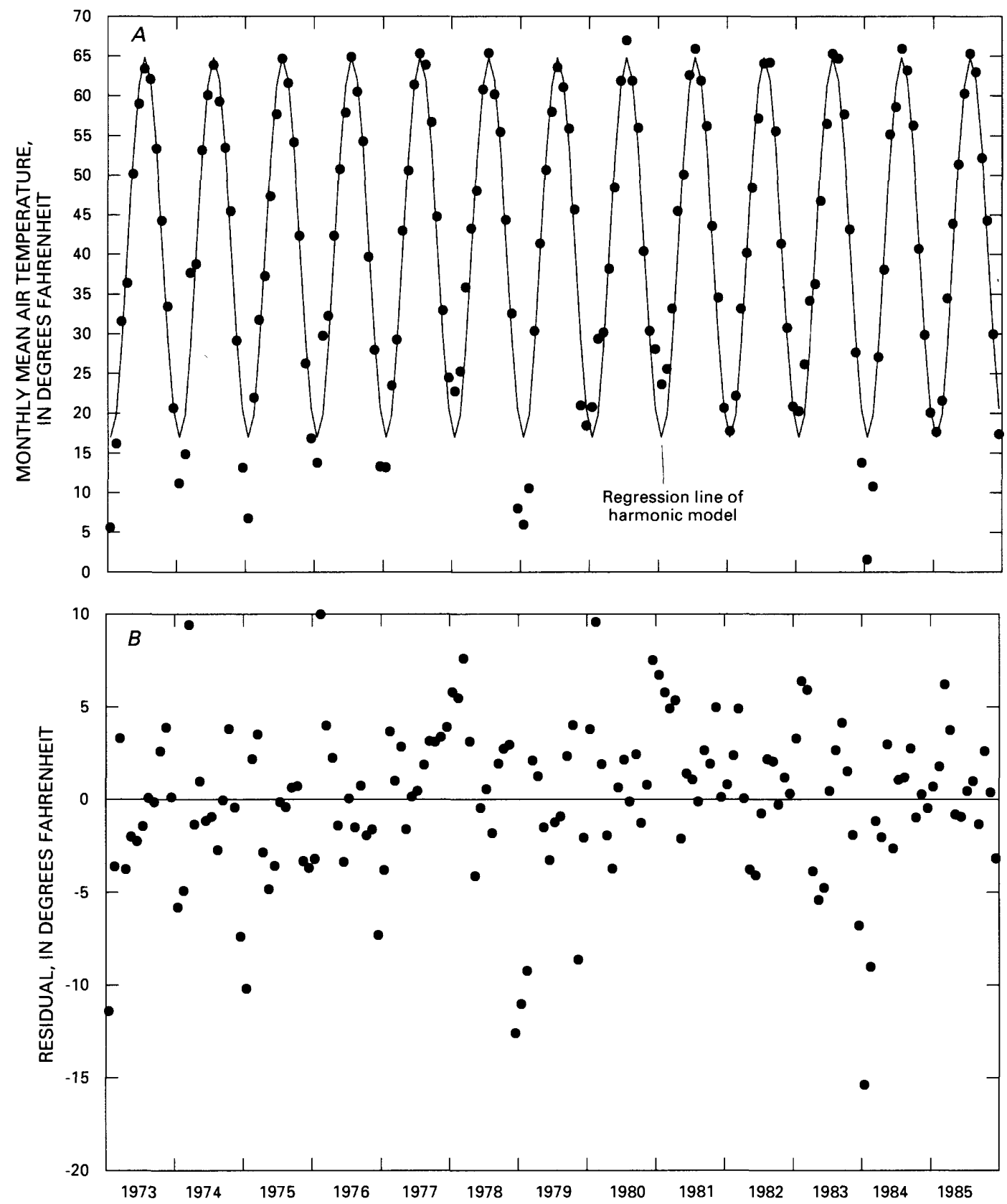

Flgure 11. (A) Monthly mean air temperature at Alamosa WSO AP and a harmonic model of monthly mean air temperature; and $(B)$ the residual, 1973-85. 

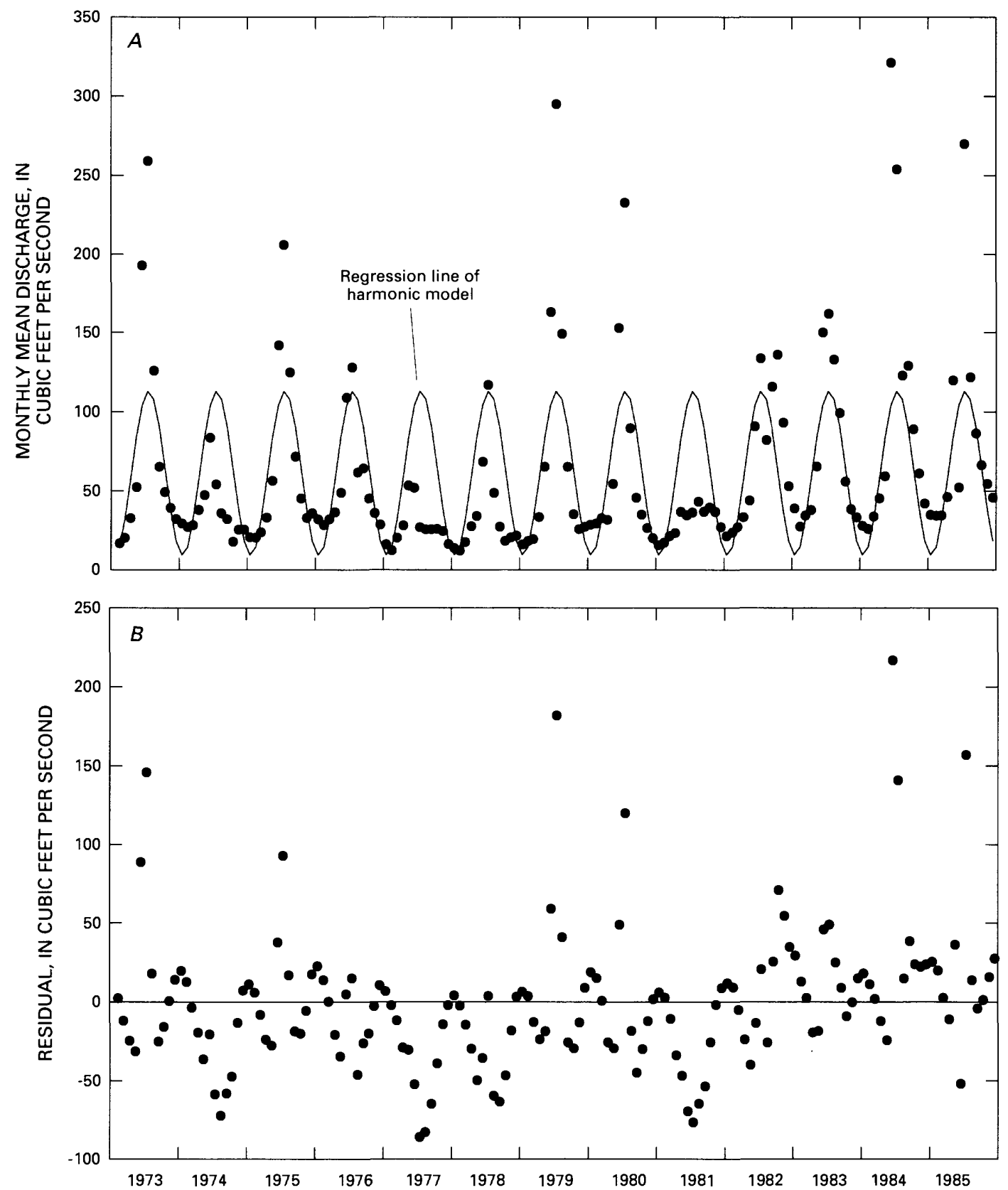

Figure 12. (A) Monthly mean discharge of Saguache Creek near Saguache and a harmonic model of monthly mean discharge; and $(B)$ the residual, 1973-85. 
266,000 acre-ft. Although Huntley did not specify the period for which he estimated the water budget of the closed basin, if Huntley's estimate is based on an equivalent historical period (1940-79), then surfacewater diversions into the closed basin were about 24 percent of the 1940-79 average annual surfacewater diversions in the San Luis Valley. Temporal variation in diversions of surface water from the Rio Grande into the closed basin is indicated by the record of depletion of flow (fig. 13) in the Rio Grande between Del Norte (gaging station 08220000) and the mouth of Trinchera Creek near La Sauses (gaging station 08240000). (See pl. 1 for locations of gaging stations.) Negative values of streamflow depletion are common in winter months when flow near La Sauses is larger than flow near Del Norte. Estimated average annual surface-water diversions into the closed basin (Huntley, 1979) are about 60 percent of the 1973-85 average depletion of the Rio Grande in the reach between Del Norte and Trinchera Creek. Annual (calendar year) depletion of the Rio Grande in the reach between Del Norte and Trinchera Creek ranged from about 165,000 acre-ft in 1977 to about 573,000 acre-ft in 1973 and 1979, and it averaged 440,000 acre-ft for 1973-85. Surface-water diversions peak in May, June, or July (fig. 13). The point values shown in figure 13A are the differences in monthly mean discharge at the gaging stations, lagged 1 month. The solid line in figure $13 \mathrm{~A}$ is predicted from a regression model of monthly depletion of the Rio Grande with the harmonic functions of time. The regression model is:

$$
\overline{\mathrm{SW}}_{\mathrm{m}}=600.52-769.93 \mathrm{X}_{\mathrm{cm}}-586.07 \mathrm{X}_{\mathrm{sm}} \text {, }
$$

where

$\overline{S W}_{m}$ is the predicted difference in monthly mean discharge of the Rio Grande between gaging stations 08220000 and 08240000 , lagged 1 month, in cubic feet per second. The residual values are assumed to be the random component of streamflow depletion. The residual is shown in figure 13B; the residual is the difference between measured streamflow depletion and the value predicted from the harmonic model $\left(\mathrm{RSW}_{\mathrm{i}}=\mathrm{SW}_{\mathrm{i}}-\overline{\mathrm{SW}}_{\mathrm{m}}\right)$.

\section{Electric Power Usage for Agricultural Purposes}

Because ground water and surface water are used in a complementary way for irrigation in the closed basin, ground-water withdrawals generally increase when the surface-water supply decreases. Annual ground-water withdrawals for irrigation in the San Luis Valley in the 1940's were estimated to range from 3,000 acre-ft in 1941 to 125,000 acre-ft in 1946 (Emery and others, 1972, table 10, p. 146). Increasing numbers of large-capacity wells withdrew ground water from the unconfined and confined aquifers underlying the San Luis Valley during 1950-79. In the drought year of 1977, an estimated 1,000,000 acre-ft of ground water was used for irrigation in the San Luis Valley (Crouch, 1985, sheet 1). Increased withdrawals of ground water for irrigation also have resulted indirectly from changes in methods of irrigation. About 1,800 irrigation systems in the San Luis Valley were converted from flood irrigation or subirrigation to sprinkler irrigation in the 1970's and 1980's (Davis Engineering Services, Inc., 1983). Because sprinkler irrigation is less labor intensive than flood irrigation, it is more likely to be used and results in increased ground-water withdrawals. Some sprinkler methods of applying ground water are substantially affected by evaporation losses before the water reaches the soil and also may result in an increase in groundwater withdrawal.

Ground-water withdrawals from the aquifers of the San Luis Valley are not metered, but most irrigation wells in the San Luis Valley have electrically powered pumps and irrigation systems. Ground-water pumpage in the San Luis Valley has been estimated from empirical relations between withdrawals and electric power usage (Emery and others, 1972; Crouch, 1985; Hearne and Dewey, 1988). Hearne and Dewey (1988, p. 74) estimated pumpage in the San Luis Valley; they assumed power-to-water conversion factors of $300 \mathrm{kWh}$ for sprinkler systems and $100 \mathrm{kWh}$ for gravity systems to pump 1 acre-ft of ground water. The annual maximum monthly electric power use for agricultural purposes, principally irrigation, by the San Luis Valley REC (fig. 14) substantially increased in the period 1973-82. The annual maximum monthly electric power use was less than $7.5 \mathrm{gWh}$ for 1973 , and it was more than $25 \mathrm{gWh}$ for each year of the period of 1980-82. Part of the increase resulted from increased use of sprinkler-irrigation systems during the 1970's. The drop in electrical usage from 1982 to 1985 coincides with an increase in surface-water diversions for the period. Negative values of electrical usage, shown in figure 14 for February 1973, November and April 1975, November 1976, February and December 1979, and December 1980, result from a time differential between the billing dates of the wholesale supplier of electricity to the REC and the dates the electrical consumers' meters were read by the REC. The electric power usage for agricultural purposes by consumers of the REC includes usage for nonirrigation purposes and electrical usage outside the closed basin, but it does not include electric power supplied by other utility companies. Seasonal and long- 

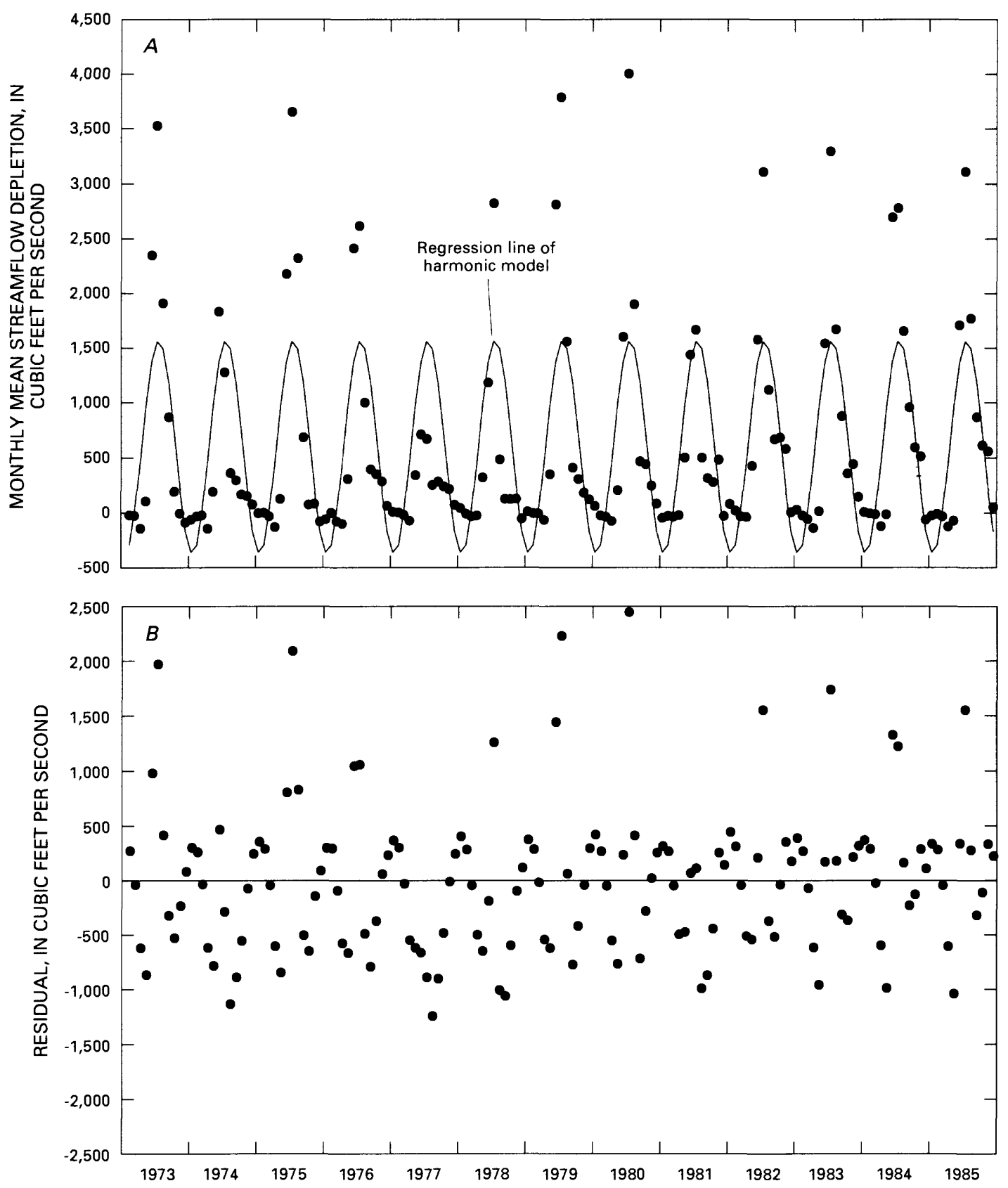

Flgure 13. (A) Monthly mean streamflow depletion of the Rio Grande between Del Norte and Trinchera Creek and a harmonic model of monthly mean depletion; and (B) the residual, 1973-85. 

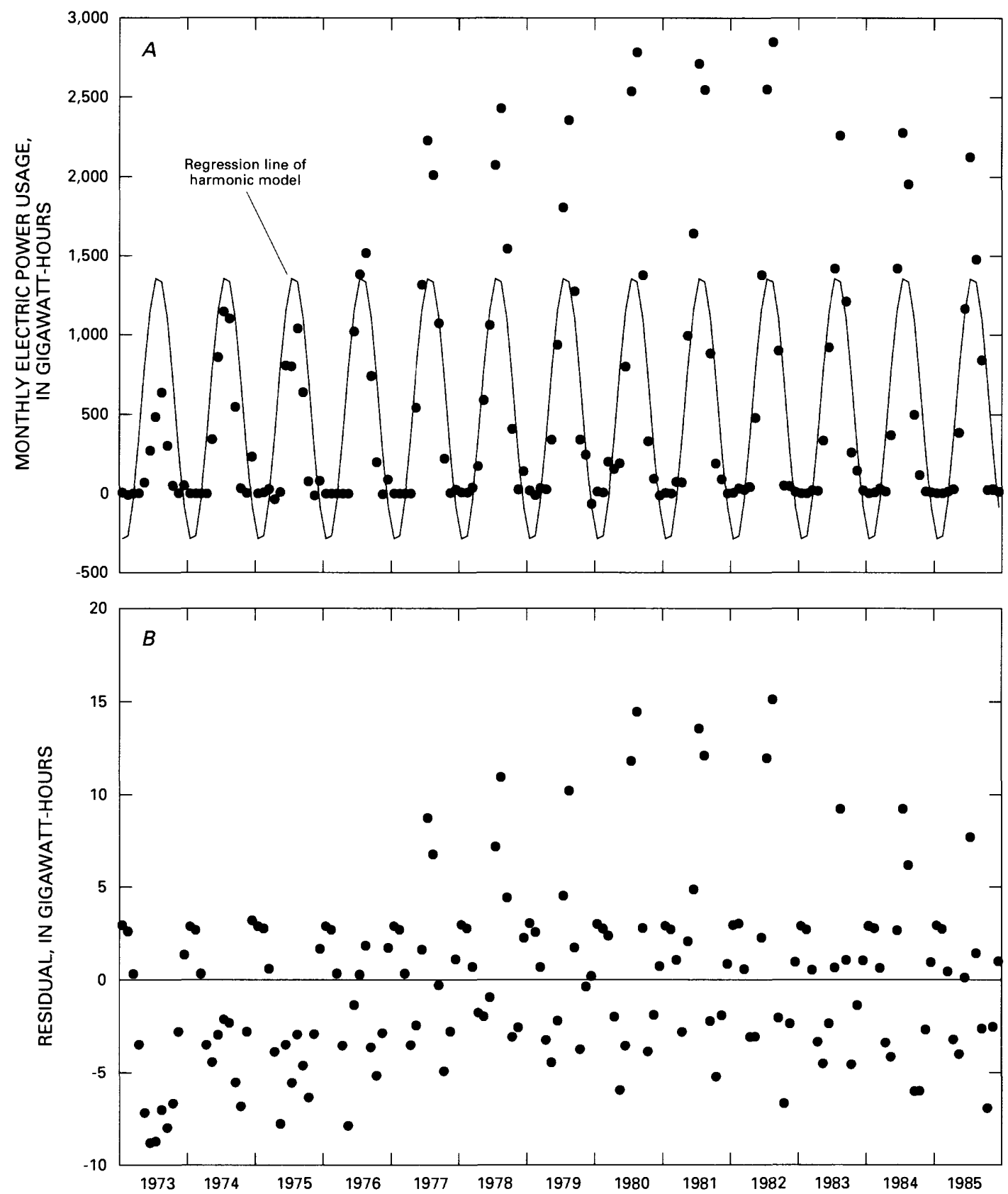

Figure 14. (A) Monthly electric power usage for agricultural purposes supplied by the San Luis Valley Rural Electric Cooperative and a harmonic model of monthly electrical use; and (B) the residual, $1973-85$. 
term variation in electric power usage for agricultural purposes is assumed to be related to withdrawals of ground water for irrigation and, consequently, to water-level change in the closed basin. The solid line in figure $14 \mathrm{~A}$ is predicted from a linear regression of electric power usage for agricultural purposes with the harmonic functions of time. The regression model is:

$$
\overline{\mathrm{GW}}_{\mathrm{m}}=5.346-6.192 \mathrm{X}_{\mathrm{cm}}-5.676 \mathrm{X}_{\mathrm{sm}} \text {, }
$$

where

$\overline{\mathrm{GW}}_{\mathrm{m}}$ is the predicted amount of monthly electric power use for agricultural purposes in gigawatt-hours and $\mathrm{X}_{\mathrm{cm}}$ and $\mathrm{X}_{\mathrm{sm}}$ are as previously defined. The residual error is assumed to be the random component of electrical use for agricultural purposes. The large residual values (fig. 14) in the late 1970's and early 1980's indicate an increase in pumpage. The point values in figure 14B are the differences between actual electrical usage and the seasonal harmonic function $\left(\mathrm{RGW}_{\mathrm{i}}=\mathrm{GW}_{\mathrm{i}}-\overline{\mathrm{GW}}_{\mathrm{m}}\right)$

\section{Predicted Monthly Values and Residuals}

Monthly values of the first-stage variables were predicted using the regression equations provided in the section entitled "Harmonic Variation of Variables Related to Recharge and Discharge." Regression models that use $X_{c}$ and $X_{s}$ to predict PP, TA, RO, SW, and GW have adjusted coefficients of determination $\left(R_{a}{ }^{2}\right)$ of 0.30 for PP, 0.94 for TA, 0.40 for RO, 0.51 for SW, and 0.61 for $\mathrm{GW}$. The larger the value of $R_{a}{ }^{2}$, the larger the proportion of the variance of the first-stage variable predicted by regression with the harmonic functions. Residuals from these regression models of PP, TA, RO, $S W$, and GW with $X_{c}$ and $X_{s}$, hereinafter are referred to as RPP, RTA, RRO, RSW, and RGW, respectively. Values of $\mathrm{X}_{\mathrm{cm}}, \mathrm{X}_{\mathrm{sm}}, \overline{\mathrm{PP}}_{\mathrm{m}}, \overline{\mathrm{TA}}_{\mathrm{m}}, \overline{\mathrm{RO}}_{\mathrm{m}}, \overline{\mathrm{SW}}_{\mathrm{m}}$, and $\overline{\mathrm{GW}}_{\mathrm{m}}$, for $\mathrm{m}=1$ to 12 , where the "- " symbol indicates a predicted value, are listed in table 3 . First-stage residuals are computed as the observed value minus the predicted value; for example, $R S W_{i}=S W_{i}-\overline{S W}_{m}$.

Table 3. Monthly values for the harmonic functions $X_{c}$ and $X_{s}$ and predicted monthly values of $\overline{P P}, \overline{T A}, \overline{R O}, \overline{S W}$, and $\overline{\mathrm{GW}}$ for the Closed Basin Division study area

[m, numeric value of month; $\mathrm{X}_{\mathrm{c}}$ and $\mathrm{X}_{\mathbf{s}}$, harmonic functions; $\overline{\mathrm{PP}}$, predicted precipitation for the previous month, in inches; $\overline{\mathrm{TA}}$, predicted mean air temperature for the previous month at Alamosa WSO AP, in degrees Fahrenheit; $\overline{R O}$, predicted discharge of Saguache Creek at station 08227000 for the previous month, in cubic feet per second; $\overline{S W}$, predicted depletion of the Rio Grande between stations 08220000 and 08240000 for the previous month, in cubic feet per second; $\overline{G W}$, predicted electrical usage for agricultural purposes, in gigawatt-hours]

\begin{tabular}{|c|c|c|c|c|c|c|c|}
\hline $\mathbf{m}$ & ${ }^{1} x_{c}$ & ${ }^{2} x_{8}$ & $\overline{\mathbf{P P}}$ & $\overline{\mathrm{TA}}$ & $\overline{\mathbf{R O}}$ & $\overline{\mathbf{s W}}$ & $\overline{\mathbf{G W}}$ \\
\hline 1 & 0.866 & 0.500 & 0.36 & 17.0 & 9.5 & -359 & -2.85 \\
\hline 2 & .500 & .866 & .27 & 19.8 & 14.5 & 292 & -2.67 \\
\hline 3 & .000 & 1.000 & .29 & 28.3 & 32.0 & 14 & -.33 \\
\hline 4 & -.500 & .866 & .42 & 40.1 & 57.3 & 478 & 3.53 \\
\hline 5 & -.866 & .500 & .61 & 52.2 & 83.7 & 974 & 7.87 \\
\hline 6 & -1.000 & .000 & .83 & 61.3 & 104.1 & 1,370 & 11.54 \\
\hline 7 & -.866 & -.500 & 1.00 & 64.8 & 112.9 & 1,560 & 13.55 \\
\hline 8 & -.500 & -.866 & 1.09 & 62.0 & 107.9 & 1,493 & 13.36 \\
\hline 9 & .000 & -1.000 & 1.06 & 53.5 & 90.4 & 1,187 & 11.02 \\
\hline 10 & .500 & -.866 & .94 & 41.7 & 65.1 & 723 & 7.17 \\
\hline 11 & .866 & -.500 & .74 & 29.6 & 38.7 & 227 & 2.82 \\
\hline 12 & 1.000 & .000 & .53 & 20.6 & 18.3 & -169 & -.85 \\
\hline
\end{tabular}

${ }^{\mathrm{T}} \mathrm{X}_{\mathrm{c}}=\cos (2 \pi \mathrm{m} / 12)$, where $\mathrm{m}$ is the number of the month.

${ }^{2} X_{s}=\sin (2 \pi \mathrm{m} / 12)$, where $m$ is the number of the month. 


\section{Correiation Among Variabies}

Pearson correlation coefficients describing correlation among the first-stage predictor variables $\mathrm{PP}$, TA, RO, SW, and GW (table 4) indicate that these variables are linearly related at 0.02 or less exceedance probability. The variables PP, TA, RO, SW, and GW also are linearly related to the harmonic functions $\mathrm{X}_{\mathrm{c}}$ and $X_{s}$ at 0.03 or less exceedance probability. The variables GW and RO are linearly related to elapsed time (T) at 0.05 or less exceedance probability. Pearson correlation coefficients for correlation among the firststage residual variables RPP, RTA, RRO, RSW, and RGW generally are smaller than the Pearson correlation coefficients for correlation among the corresponding first-stage predictor variables. Pearson correlation coefficients for correlation between RSW and RTA, between RGW and RRO, between RGW and RTA, between RRO and RPP, between RRO and RTA, and between RPP and RTA indicate that the first-stage residuals from the regression of $P P, T A, R O, S W$, and $G W$ with the harmonic functions $X_{c}$ and $X_{s}$, either are not linearly correlated or exhibit less linear correlation than the corresponding first-stage predictor variables.

Not only are the first-stage predictor variables (PP, TA, RO, SW, and GW) correlated with each other, but they also are serially correlated. Pearson correlation coefficients describing correlation between the first-stage predictor variables $\mathrm{PP}, \mathrm{TA}, \mathrm{RO}, \mathrm{SW}$, and GW and their own values for the previous 12 months (fig. 15) indicate that the variables are serially correlated to various degrees. The serial correlation probably results from seasonal variation due to climatic influence. The close correspondence between the curve of Pearson correlation coefficients for serial correlation of air temperature and that for the harmonic functions (fig. 15) shows that air temperature approximates a harmonic function. The first-stage predictor variables $\mathrm{GW}$ (electrical use for agricultural purposes) and SW (stream depletion of the Rio Grande) have a fairly large serial correlation at a lag of 12 months. The regressors PP (monthly precipitation) and RO (discharge of Saguache Creek) have the least serial correlation coefficient at a 12-month lag; a small serial correlation indicates greater variation between years.

\section{Seiection of Variables}

Eight second-stage predictor variables $\left(T, X_{c}\right.$, $X_{s}, R P P, R T A, R R O, R S W$, and RGW) were considered for inclusion in a regression model for each well. Each of the final models includes a subset of these eight variables. The "best" subset of second-stage predictor variables was selected as the one that resulted in the subset model in which the adjusted coefficient of determination $\left(\mathrm{R}_{\mathrm{a}}{ }^{2}\right)$ was maximized and for which the value of Mallows' $C_{p}$ statistic was approximately equal to the number of second-stage predictor variables in the subset model. Statistics for each model were computed using the RSQUARE procedure (SAS Institute Inc., 1985, p. 711-724). Models that include one, but not both, of the harmonic functions $\mathrm{X}_{\mathrm{c}}$ and $\mathrm{X}_{\mathrm{s}}$ were not considered; therefore, 128 possible subset models were considered for each well. A total of 5,888 regression models were considered for the 46 selected observation wells.

The $\mathrm{R}_{\mathrm{a}}{ }^{2}$ statistic is the coefficient of determination $\left(R^{2}\right)$ adjusted for the number of predictor variables in the regression model. Maximizing $\mathrm{R}_{\mathrm{a}}{ }^{2}$ is equivalent to minimizing the mean square error (MSE). Although the $\mathrm{R}^{2}$ statistic increases as the number of predictor variables in a regression model increases, the $R_{a}{ }^{2}$ statistic does not necessarily increase as additional predictor variables are introduced into the model (Montgomery and Peck, 1982, p. 251).

Mallows' $C_{p}$ statistic (Montgomery and Peck, 1982 , p. 252-254) is a measure of the bias of a model that includes a subset of the predictor variables in the full model. Regression models with little bias have $\mathrm{C}_{\mathrm{p}}$ statistics approximately equal to the number of predictor variables. Small values of $\mathrm{C}_{\mathrm{p}}$ generally are preferable. The $\mathrm{C}_{\mathrm{p}}$ statistic for a full model, the model which includes all predictor variables, will equal the number of predictor variables plus one; for a full model that includes seven predictor variables, $C_{p}$ equals 8 . The $C_{p}$ statistic is most easily evaluated by plotting $C_{p}$ as a function of the number of predictor variables $(k)$ in a subset model. Subset models that have values of $C_{p}$ near the line, $C_{p}=k$, have the least bias. According to Montgomery and Peck (1982, p. 254), "If the full model has several regressors that do not contribute significantly to the model (zero regression coefficients), then $\operatorname{MSE}(K+1)$ will often overestimate $\sigma^{2}$, and consequently the values of $C_{p}$ will be small." $M S E(K+1)$ is the mean square error and $\sigma^{2}$ the variance of the full model. Where the full model included predictor variables with zero regression coefficients, the Mallows' $\mathrm{C}_{\mathrm{p}}$ statistic was not used in model selection. 
Table 4. Pearson correlation coefficients and exceedance probabilities for the predictor variables used in regression models of water-level change in the Closed Basin Division study area

(Note: The number of observations is 155 for variables SW, RO, PP, RSW, RRO, and RPP, and 156 for variables T, $X_{c}, X_{s}$, GW, TA, RGW, and RTA. The upper numbers are the Pearson correlation coefficients; the lower numbers are the exceedance probabilities. Exceedance probability is the probability of getting a larger sample correlation coefficient when the population correlation coefficient actually is zero. An exceedance probability less than 0.05 indicates a significant linear correlation between variables]

\begin{tabular}{|c|c|c|c|c|c|c|c|c|c|c|c|c|c|}
\hline \multirow{2}{*}{$\begin{array}{l}\text { Vari- } \\
\text { able }\end{array}$} & \multicolumn{3}{|c|}{ Time-related variables } & \multicolumn{5}{|c|}{ First-stage predictor variables } & \multicolumn{5}{|c|}{ Second-stage predictor variables } \\
\hline & $\mathbf{T}$ & $x_{c}$ & $x_{8}$ & PP & TA & RO & sw & GW & RPP & RTA & RRO & RSW & RGW \\
\hline \multirow[t]{2}{*}{$\mathbf{T}$} & 1 & 0.02 & -0.06 & 0.12 & 0.04 & 0.17 & 0.06 & 0.16 & 0.12 & 0.10 & 0.21 & 0.08 & 0.22 \\
\hline & 0 & .85 & .47 & .13 & .61 & .04 & .44 & .05 & .13 & .22 & .01 & .32 & .01 \\
\hline \multirow[t]{2}{*}{$\mathrm{X}_{\mathrm{c}}$} & & 1 & 0 & -.17 & -.83 & -.52 & -.56 & -.58 & 0 & 0 & 0 & 0 & 0 \\
\hline & & 0 & 1 & .03 & $<.01$ & $<.01$ & $<.01$ & $<.01$ & 1 & 1 & 1 & 1 & 1 \\
\hline \multirow[t]{2}{*}{$X_{s}$} & & & 1 & -.53 & -.51 & -.35 & -.43 & -.53 & 0 & 0 & 0 & 0 & 0 \\
\hline & & & 0 & $<.01$ & $<.01$ & $<.01$ & $<.01$ & $<.01$ & 1 & 1 & 1 & 1 & 1 \\
\hline \multirow[t]{2}{*}{ PP } & & & & 1 & .40 & .21 & .19 & .29 & .83 & -.10 & -.09 & -.20 & -.14 \\
\hline & & & & 0 & $<.01$ & $<.01$ & .02 & $<.01$ & $<.01$ & .23 & .28 & .01 & .08 \\
\hline \multirow[t]{2}{*}{$\mathrm{TA}$} & & & & & 1 & .60 & .68 & .75 & -.02 & .24 & -.02 & -.02 & $<.01$ \\
\hline & & & & & 0 & $<.01$ & $<.01$ & $<.01$ & .76 & $<.01$ & .82 & .84 & .95 \\
\hline \multirow[t]{2}{*}{ RO } & & & & & & 1 & .87 & .53 & -.08 & -.08 & .78 & .61 & .07 \\
\hline & & & & & & 0 & $<.01$ & $<.01$ & .31 & .33 & $<.01$ & $<.01$ & .42 \\
\hline \multirow[t]{2}{*}{ SW } & & & & & & & 1 & .68 & -.17 & -.07 & .55 & .70 & .20 \\
\hline & & & & & & & 0 & $<.01$ & .03 & .40 & $<.01$ & $<.01$ & .01 \\
\hline \multirow[t]{2}{*}{ GW } & & & & & & & & 1 & -.11 & .01 & .05 & .17 & .62 \\
\hline & & & & & & & & 0 & .18 & .88 & .54 & .03 & $<.01$ \\
\hline \multirow[t]{2}{*}{ RPP } & & & & & & & & & 1 & -.10 & -.10 & -.24 & -.17 \\
\hline & & & & & & & & & 0 & .20 & .20 & $<.01$ & .03 \\
\hline \multirow[t]{2}{*}{ RTA } & & & & & & & & & & 1 & -.08 & -.07 & .02 \\
\hline & & & & & & & & & & 0 & .32 & .38 & .81 \\
\hline \multirow[t]{2}{*}{ RRO } & & & & & & & & & & & 1 & .78 & .08 \\
\hline & & & & & & & & & & & 0 & $<.01$ & .33 \\
\hline \multirow[t]{2}{*}{ RSW } & & & & & & & & & & & & 1 & .28 \\
\hline & & & & & & & & & & & & 0 & $<.01$ \\
\hline RGW & & & & & & & & & & & & & 1 \\
\hline
\end{tabular}




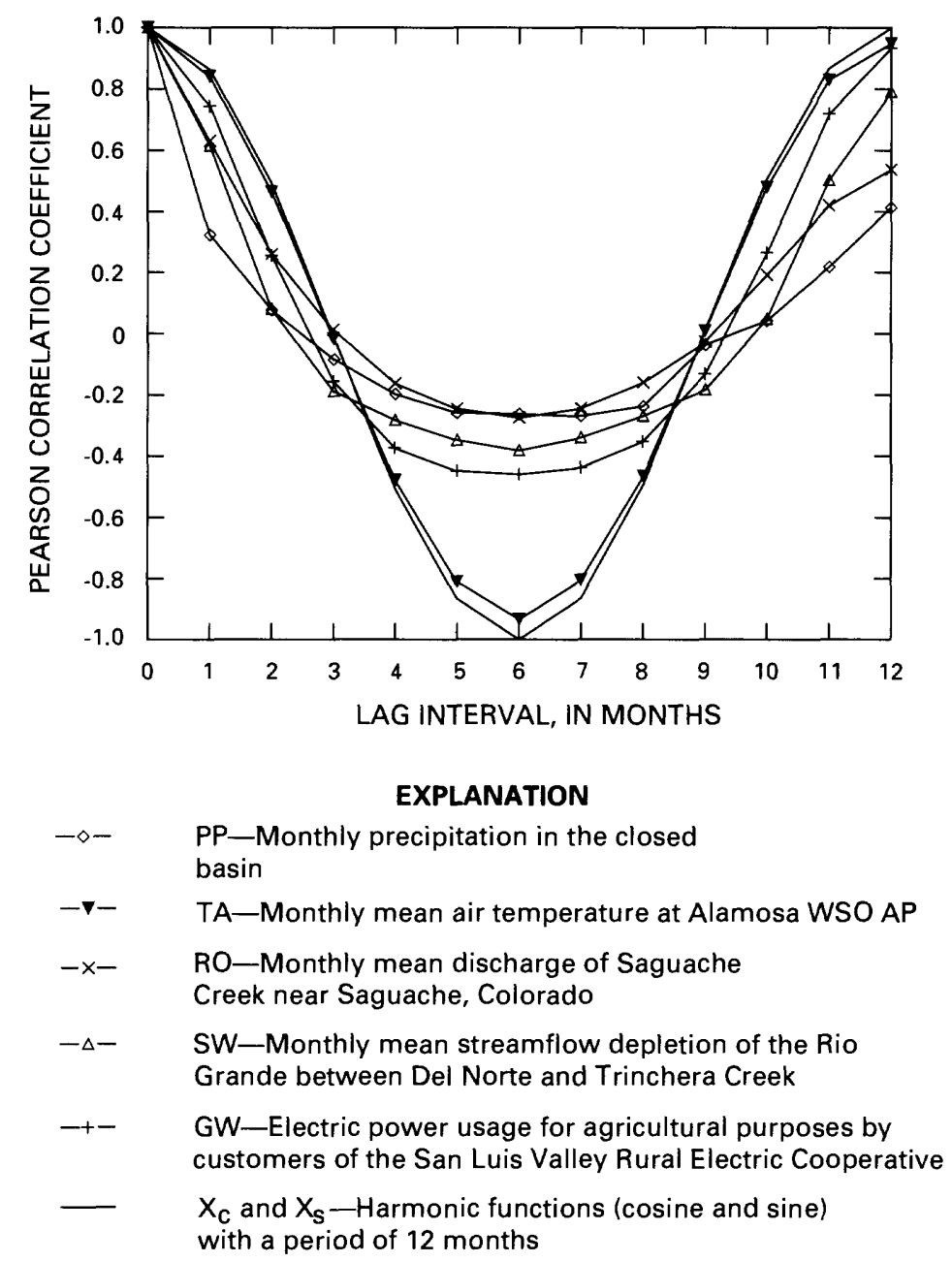

Figure 15. Serial correlation of first-stage predictor variables $X_{c}, X_{s}$, PP, TA, RO, SW, and GW for regression models of water-level change in the Closed Basin Division study area.

\section{Statistics for Model Evaluation}

The adequacy of the regression models of monthly water-level change was evaluated based on the following statistics: (1) $\mathrm{R}_{\mathrm{a}}{ }^{2}$, the adjusted coefficient of determination; (2) $\mathrm{SE}_{\mathrm{e}}$, the standard error of estimate; and (3) d, the Durbin-Watson test statistic for first-order serial correlation of the residual errors (Draper and Smith, 1981, p. 162-169). Brief descriptions of the test statistics are provided in the following paragraphs. Detailed discussions of the testing of regression equations and regression coefficients, and tests for serial correlation, are provided in most statistics textbooks, including Montgomery and Peck (1982) and Wonnacott and Wonnacott (1984).
The adjusted coefficient of determination, $\mathrm{R}_{\mathrm{a}}{ }^{2}$, is the square of the multiple correlation coefficient, adjusted for the number of predictor variables included in the model. $\mathrm{R}_{\mathrm{a}}{ }^{2}$ is the proportion of the variance of the response variable explained by the model, and $\left(1-R_{a}{ }^{2}\right)$ is the proportion of the variance of the response variable not explained by the model. As $R_{a}{ }^{2}$ increases, the model explains more of the variance in the response variable. The standard error of estimate $\left(\mathrm{SE}_{\mathrm{e}}\right)$ of the regression is the standard deviation of the residual errors from the model. The smaller the standard error of estimate, the better the model is at predicting the response variable. The standard error of estimate is minimized as $\mathrm{R}_{\mathrm{a}}{ }^{2}$ is maximized. 
The Durbin-Watson test (Draper and Smith, 1981 ) is used to detect serial correlation in the residuals, $e_{i}$. If the residuals are normal, independent, random variables, then all serial correlations $\mathrm{a}_{\mathrm{s}}$, are zero, where $a_{s}=$ correlation between observations s steps apart in the time series. For the Durbin-Watson test, the null hypothesis is $\mathrm{H}_{0}: \mathrm{a}_{\mathrm{s}}=0$, and the alternative hypothesis is $H_{a}: a_{s}=a^{s}$, where $a \neq 0$ and $|a|<1$. The test statistic, $d$, is computed as follows:

$$
d=\sum_{i=2}^{n}\left(e_{i}-e_{i-1}\right)^{2} / \sum_{i=1}^{n} e_{i}^{2}
$$

Montgomery and Peck (1982, table A.6, p. 478) provide tables showing lower and upper critical values, $d_{L}$ and $d_{U}$, for various sample sizes ( $n=15$ to 100$)$, for 1 through 5 predictor variables, and for 3 significance levels. A significance level, $\alpha$, of 0.05 was used in this study for evaluation of the $d$ statistic. If the sample size was larger than 100 , or if the number of predictor variables was greater than 5 , the values of $d_{L}$ and $d_{U}$ were graphically estimated.

If the Durbin-Watson d statistic is less than 2.0, the test is for positive serial correlation, and if the $d$ statistic is greater than 2.0 , the test is for negative serial correlation. The Durbin-Watson test for positive serial correlation $\left(\mathrm{H}_{\mathrm{a}}: \mathrm{a}_{\mathrm{s}}>0\right)$ of residuals indicates

(1) if $d<d_{L}, d$ is significant and $H_{0}: a_{s}=0$ is rejected;

(2) if $d>d_{U}, d$ is not significant and $H_{0}: a_{s}=0$ is not rejected; and (3) if $d_{L} \leq d \leq d_{U}$, the test is inconclusive. The Durbin-Watson test for negative serial correlation $\left(H_{\mathrm{a}}: \mathrm{a}_{\mathrm{s}}<0\right)$ of residuals is similar, except $4-\mathrm{d}$ is evaluated instead of $d$. For the purposes of the Durbin-Watson test, the harmonic functions $\mathrm{X}_{\mathrm{c}}$ and $\mathrm{X}_{\mathrm{s}}$ are considered to be a single second-stage predictor variable because they were included in, or excluded from, the models as a unit and because they are functions of a single variable, $\mathrm{m}$. For example, for well USBR EW $2 U$, the d statistic is 1.76 , the sample size, $\mathrm{n}$, is 50 , and the number of predictor variables, $\mathrm{k}$, is 3 . The lower critical value, $d_{L}$, and upper critical value, $d_{U}$, are obtained from a table of such values (Montgomery and Peck, 1982, table A.6, p. 478) for $\mathrm{n}=50, \mathrm{k}=3$, and $\alpha=0.05, \mathrm{~d}_{\mathrm{L}}=1.42$ and $\mathrm{d}_{\mathrm{U}}=1.67$. Because the $d$ statistic for the regression model of water-level change at USBR EW $2 \mathrm{U}$ is 1.76 and is larger than $d_{U}$, the null hypothesis $\left(H_{0}: a_{s}=0\right)$ is not rejected, and the residuals are not serially correlated. In another example, the $d$ statistic for the regression model of water-level change at well RGWCD 27 is 2.30 , a value that indicates a possible negative serial correlation of the residuals. For $n=101, k=3$, and $\alpha=0.05, d_{L}=1.61$ and $d_{U}=1.74$. Because $d$ is greater than 2 , the null hypothesis is evaluated by subtracting $d$ from 4. Because the result, 1.70 , is between $d_{L}$ and $d_{U}$, the test is inconclusive and does not indicate whether or not the residuals are serially correlated.

Results of the Durbin-Watson test for first-order serial correlation of the models listed in table 5 are indicated by a " + " when the null hypothesis $\left(\mathrm{H}_{0}: \mathrm{a}_{\mathrm{s}}=0\right)$ is not rejected, and by a "?" when the test is inconclusive at $\alpha=0.05$. None of the regression models had $d$ statistics smaller than lower critical level $\left(\mathrm{d}_{\mathrm{L}}\right)$ at $\alpha=0.05$; therefore, none of the final regression models had residuals that were identified as serially correlated.

\section{Parameters of Regression Models}

The Durbin-Watson test for 24 of the 46 preliminary second-stage regression models of water-level change indicated that these regression models had serially correlated residual errors. In addition, the $\mathrm{R}_{\mathrm{a}}{ }^{2}$ statistics for many of the preliminary second-stage models indicated that only a small part of the variance in monthly water-level change was explained by the models.

The preliminary second-stage regression models that had serially correlated residuals were modified to decrease the effect of serial correlation. The revised models are linear or multiple-linear regression models with first-order autoregressive terms. These models can be expressed in vector form:

$$
y_{i}=x_{i} \beta+v_{j}, i=1,2, \ldots, n
$$

where

$y_{i}=$ the response variable;

$\mathbf{x}_{\mathbf{i}}=\mathbf{a}$ vector of predictor variables;

$\beta=a$ vector of regression parameters;

$v_{i}=$ an autoregressive error term for observation $i$, defined as: $v_{i}=e_{i}$ for $i=1$ and $v_{i}=e_{i}-a_{1} v_{i-1}$ for $i>1$;

$a_{1}=$ the first-order serial correlation coefficient;

$e_{i}=a$ normally distributed residual error for the

$\mathrm{i}^{\text {th }}$ term; and

n = the number of observations.

(Note: The sign convention in the preceding equation for $v_{i}$ is reversed from that cited in some literature.) 


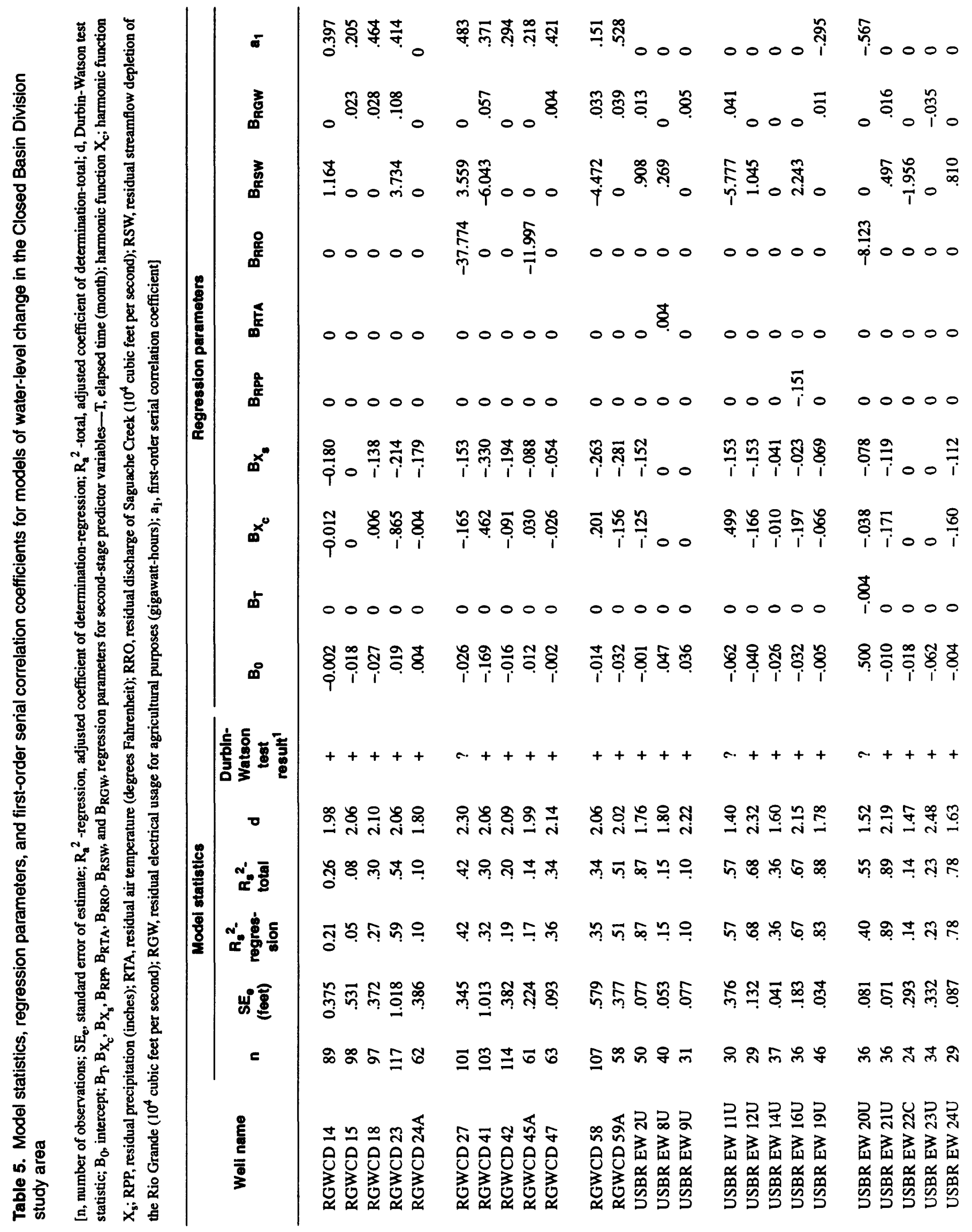

32 Regression Models of Monthly Water-Level Change In and Near the Closed Basin Division of the San Luls Valley, 


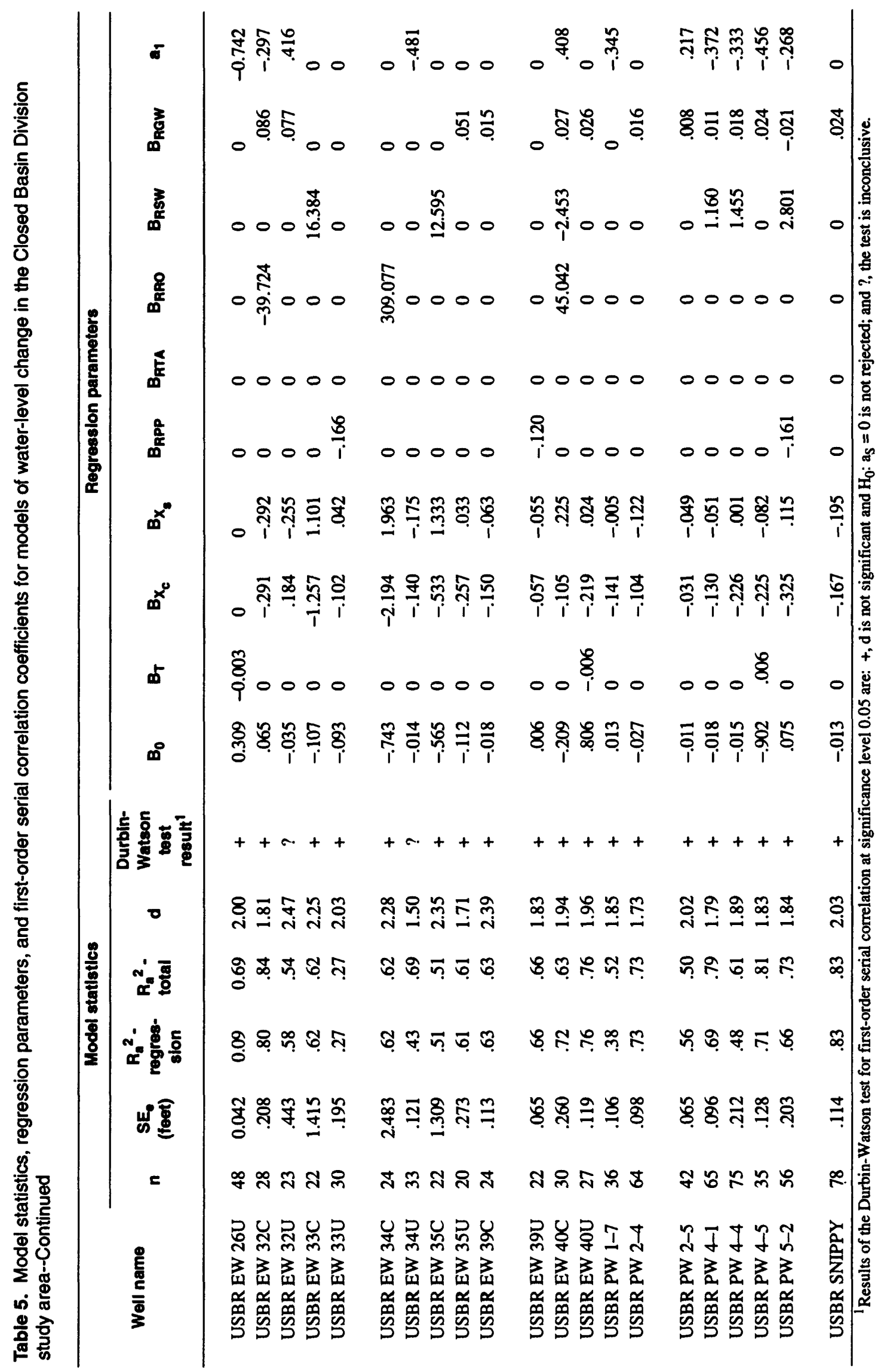


The regression models of water-level change for the 46 selected observation wells were computed using the AUTOREG procedure (SAS Institute Inc., 1988, p. 171-200). The maximum-likelihood method was used with the AUTOREG procedure because the series of water-level changes for most wells had missing values. Statistics for evaluating the models, regression parameters, and first-order serial correlation coefficients for the models are listed in table 5.

The standard errors of estimate $\left(\mathrm{SE}_{\mathrm{e}}\right)$ of the models range from $0.034 \mathrm{ft}$ for well USBR EW 19U to $2.483 \mathrm{ft}$ for well USBR EW $34 \mathrm{C}$ (table 5). The $\mathrm{SE}_{\mathrm{e}}$ of 5 regression models exceeds $1.0 \mathrm{ft}$, but $\mathrm{SE}_{\mathrm{e}}$ is less than $0.5 \mathrm{ft}$ for 39 of the regression models. Of the 39 regression models with $\mathrm{SE}_{\mathrm{e}}$ values less than $0.5 \mathrm{ft}, 14$ regression models have $\mathrm{SE}_{\mathrm{e}}$ values less than $0.1 \mathrm{ft}$. Two $R_{a}{ }^{2}$ statistics are listed for each model in table 5, the $R_{a}{ }^{2}$-regression and the $R_{a}{ }^{2}$-total. When the first-order serial correlation coefficient, $a_{1}$, equals zero, these statistics are equal. When $a_{1}$ is not equal to zero and the model is termed an autoregressive model, the autoregressive term is the product of $a_{1}$ and the residual error of the previous predictor. For autoregressive models, $\mathrm{R}_{\mathrm{a}}{ }^{2}$-regression is a measure of the fit of the structural part of the model; the part not including the autoregressive term. $R_{a}{ }^{2}$-total is a measure of how well the next value of the response variable can be predicted using the structural part of the model and the autoregressive term. In some cases, $\mathrm{R}_{\mathrm{a}}{ }^{2}$-regression is larger than $R_{a}{ }^{2}$-total. $R_{a}{ }^{2}$-total for the 46 regression models of water-level change ranges from 0.08 for well RGWCD 15 to 0.89 for well USBR EW $21 U$. Thirty of the regression models have $R_{a}{ }^{2}$-total greater than or equal to 0.5 . A relatively small $R_{a}{ }^{2}$-total statistic indicates a lack of fit of the model, whereas a relatively large $\mathrm{R}_{\mathrm{a}}{ }^{2}$-total statistic indicates a good fit of the model. Lack of fit of some of the models may result from spatial variation in rates of recharge and discharge; for example, an observation well near a largecapacity production well likely would have been affected more by nearby pumpage than by regional recharge and discharge processes.

Regression models that have relatively small $S E_{e}$ and a relatively large $R_{a}{ }^{2}$-total statistic closely predict monthly water-level change. Regression models for 18 wells completed in the unconfined aquifer (RGWCD 59A, USBR EW 2U, EW 11U, EW 12U,
EW 16U, EW 19U, EW 20U, EW 21U, EW 24U, EW 26U, EW 32U, EW 34U, EW 35U, EW 39U, EW 40U, PW 4-5, PW 5-2, and SNIPPY) have $\mathrm{SE}_{\mathrm{e}}$ less than $0.5 \mathrm{ft}$ and $\mathrm{R}_{\mathrm{a}}{ }^{2}$-total greater than or equal to 0.5 (table 5). Regression models for eight wells completed in confined aquifers (USBR EW 32C, EW 39C, EW 40C, PW 1-7, PW 2-4, PW 2-5, PW 4-1, and $P W$ 4-4) also have $S E_{e}$ less than $0.5 \mathrm{ft}$ and $R_{a}{ }^{2}$-total greater than or equal to 0.5 (table 5). In addition, regression models for wells USBR EW 33C, EW 34C, and EW 35C have $R_{a}{ }^{2}$-total greater than 0.5 and $S E_{e}$ greater than $0.5 \mathrm{ft}$; the relatively large $\mathrm{SE}_{\mathrm{e}}$ for the models for these wells is a result of the relatively large range in monthly water-level change values for wells completed in the confined aquifers (table 2).

To allow visual evaluation of serial correlation in the residuals, a graph of residual errors plotted versus time is provided for each of the regression models (figs. 16 through 24 and Appendix B). For many of the models, the variance of the residuals appears to be heteroscedastic (of changing variance) with respect to time (figs. 18B and 23B). The range of residuals before 1983 is larger than after 1983 for figure 18B and is larger after about 1983 for figure 23B. The cause of heteroscedastic variance in the residuals is unknown, but it could be related to long-term variation in local recharge and discharge conditions.

The estimated regression parameters for each model are listed in table 5. A value of 0 for any of the regression parameters indicates that the corresponding second-stage predictor variable does not significantly affect the prediction of the response variable. The firstorder serial correlation coefficient, $a_{1}$, is a measure of the correlation between successive residuals from a least-squares regression. The first-order serial correlation coefficients for the 26 models that have serially correlated residuals ranges from -0.742 for well USBR EW 26U to 0.528 for well RGWCD 59A (table 5).

Elapsed time, $\mathrm{T}$, is a significant second-stage predictor variable in the regression models for four of the wells (USBR EW 20U, USBR EW 26U, USBR EW 40U, and USBR PW 4-5). The harmonic functions $X_{c}$ and $X_{s}$ are significant second-stage predictor variables in 40 of the regression models, RPP in 4 models, RTA in only 1 model, RRO in 6 models, RSW in 19 models, and RGW in 26 models. By inference, regional water use (represented through RSW and RGW) is a more important control on water-level change than regional climatic factors (represented through RPP, RTA, and RRO). 

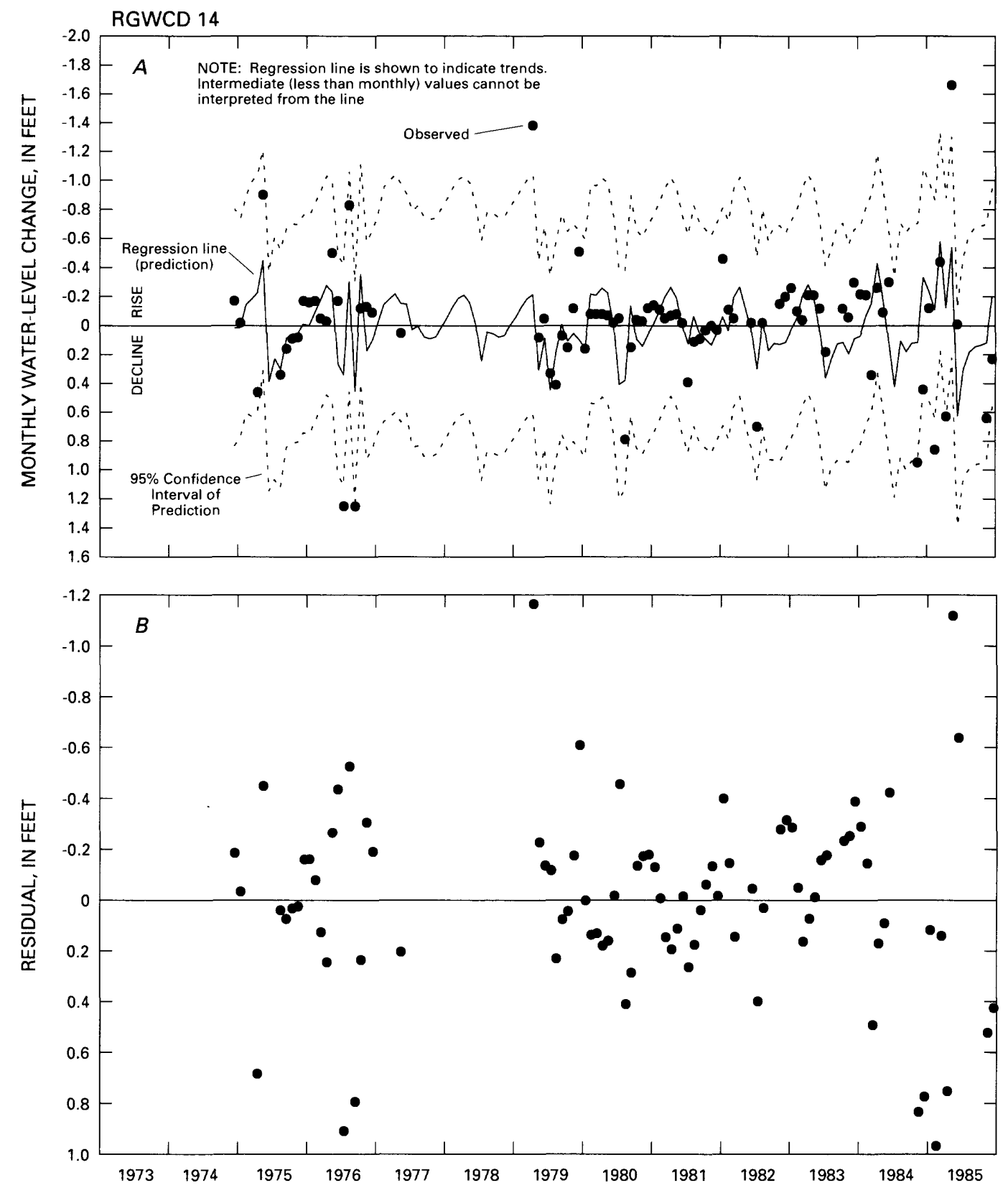

Figure 16. (A) Observed and predicted monthly water-level change and confidence limits; and (B) residual errors for observation well RGWCD 14, closed basin of San Luis Valley. 

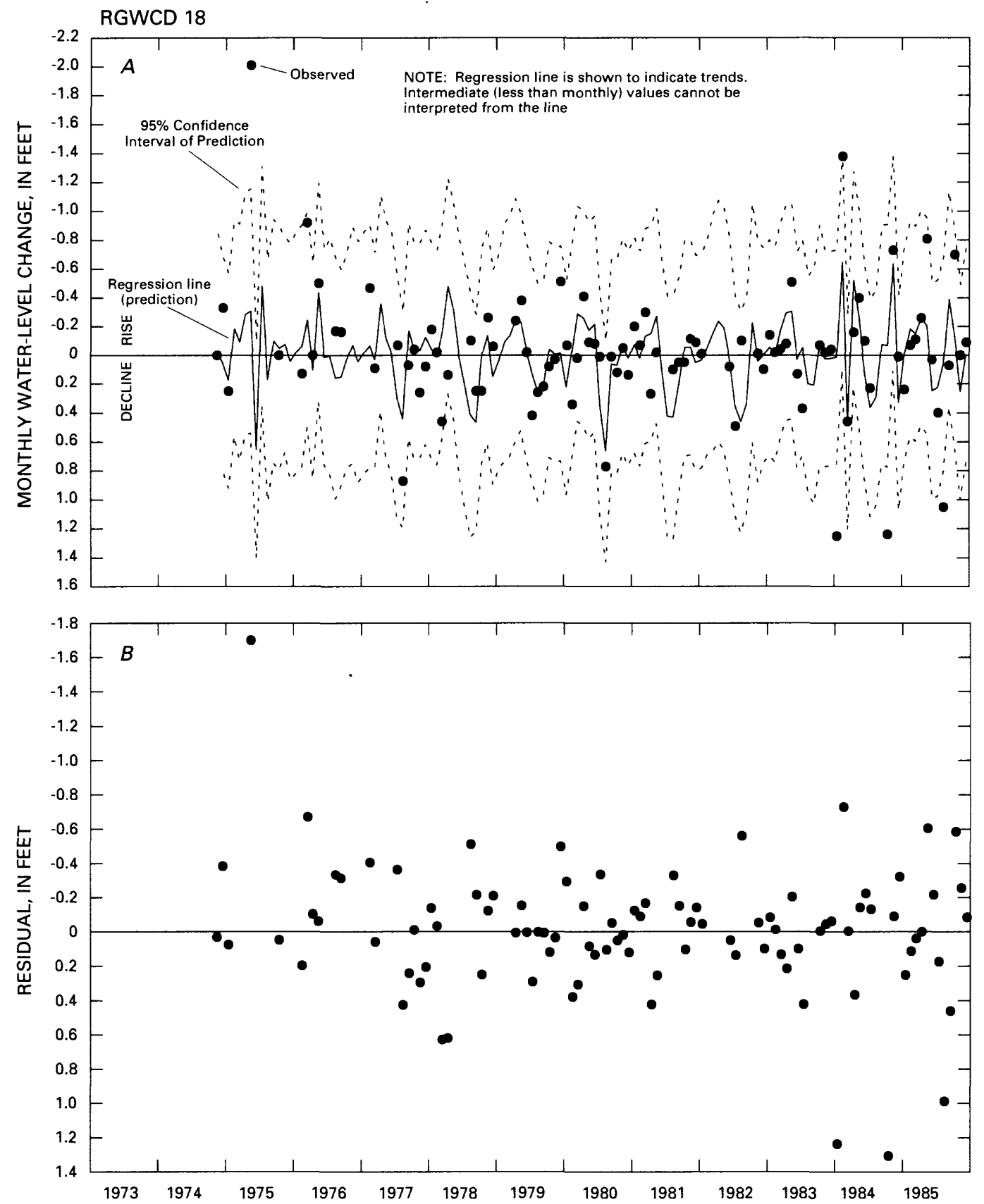

Figure 17. (A) Observed and predicted monthly water-level change and confidence limits; and (B) residual errors for observation well RGWCD 18, closed basin of San Luis Valley. 

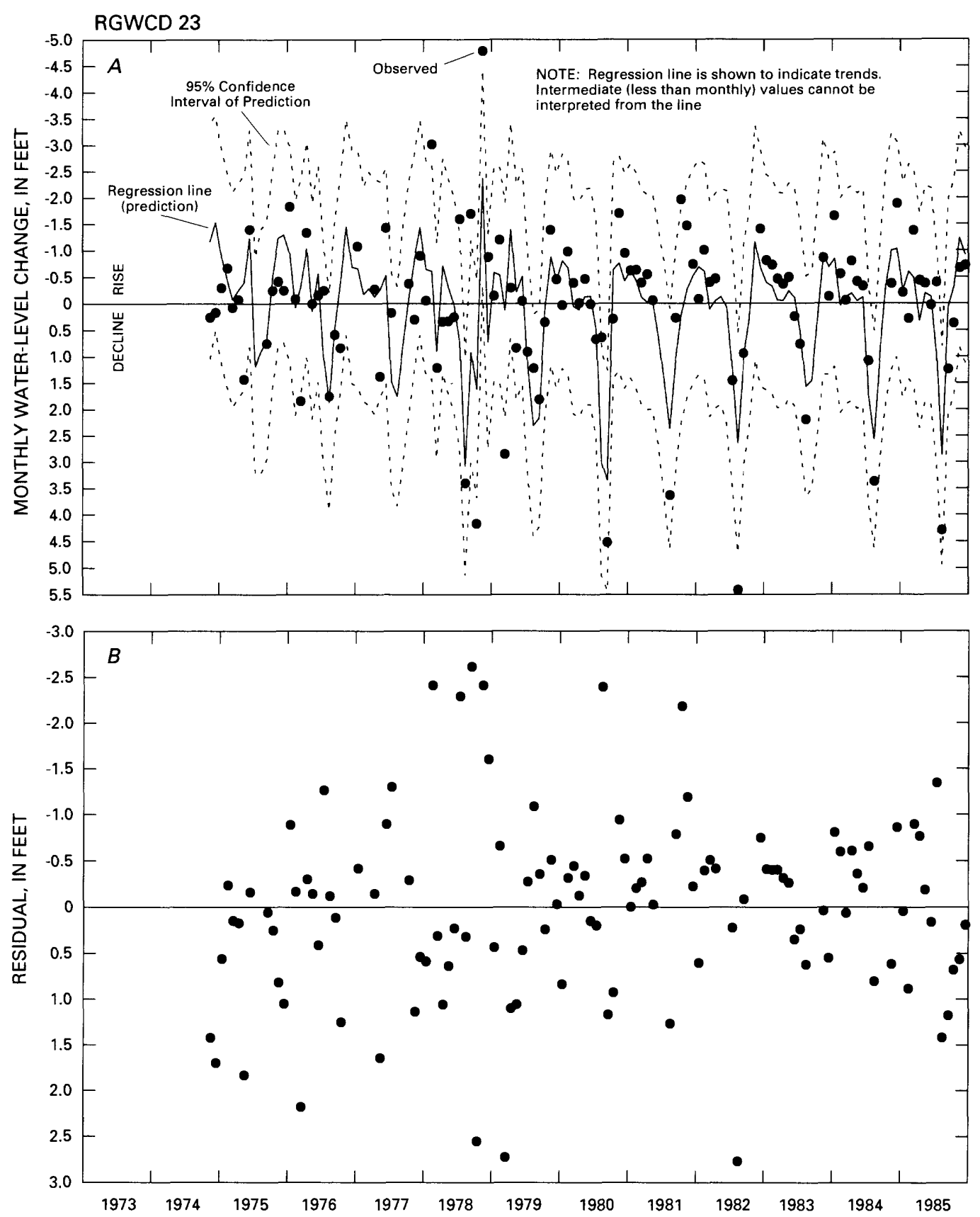

Flgure 18. (A) Observed and predicted monthly water-level change and confidence limits; and (B) residual errors for observation well RGWCD 23, closed basin of San Luis Valley. 

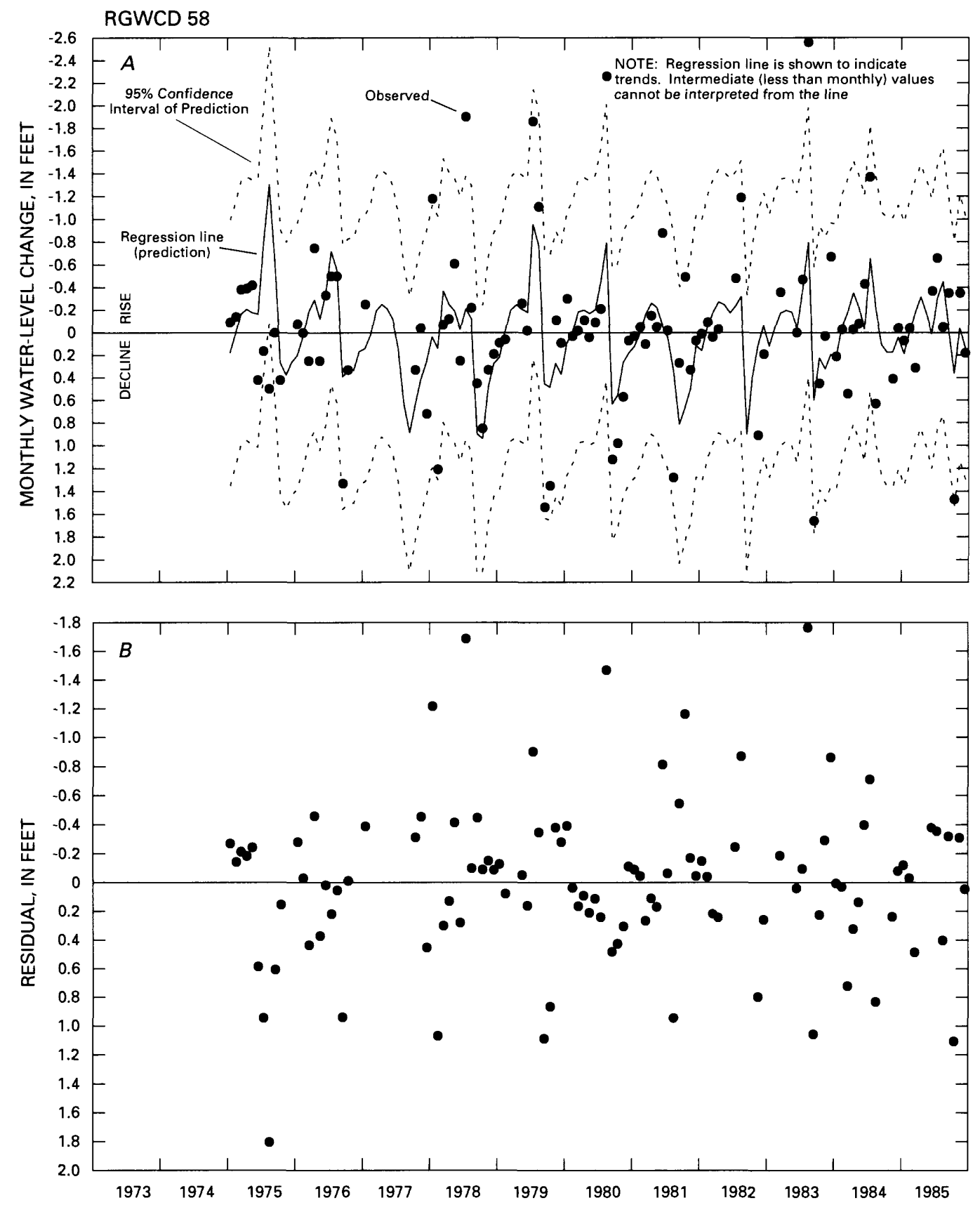

Figure 19. (A) Observed and predicted monthly water-level change and confidence limits; and (B) residual errors for observation well RGWCD 58, closed basin of San Luis Valley. 

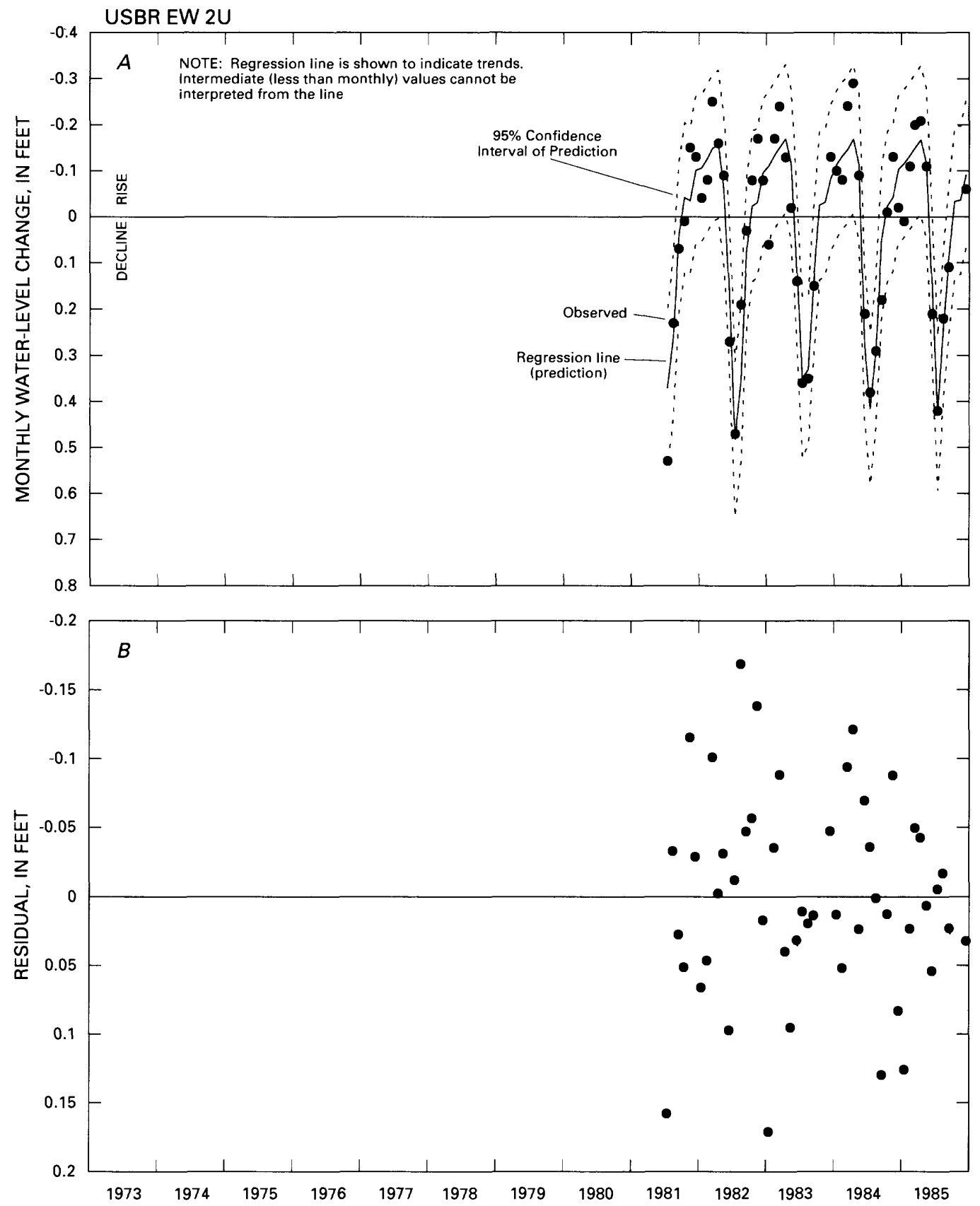

Flgure 20. (A) Observed and predicted monthly water-level change and confidence limits; and (B) residual errors for observation well USBR EW 2 , closed basin of San Luis Valley. 

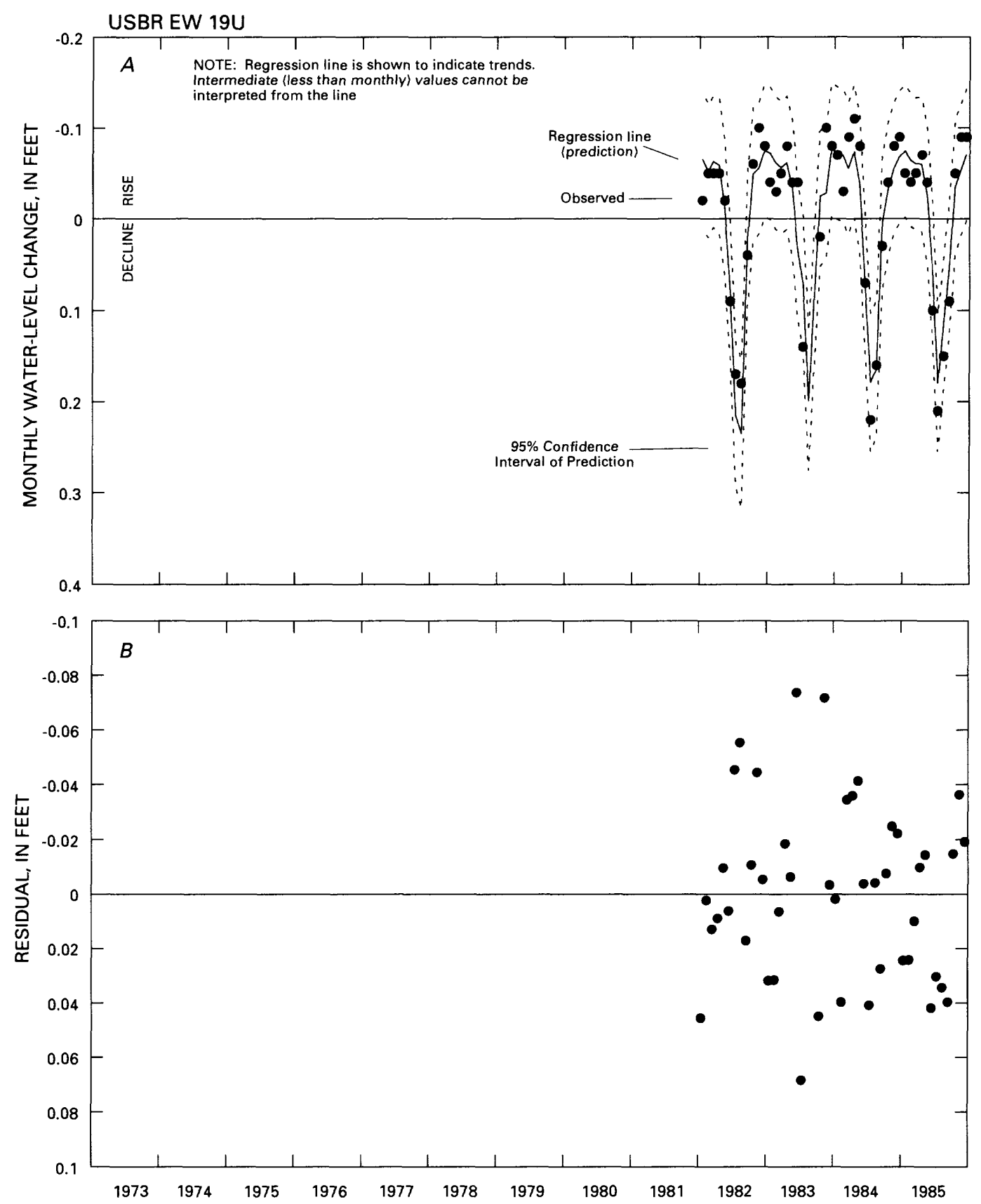

Figure 21. (A) Observed and predicted monthly water-level change and confidence limits; and (B) residual errors for observation well USBR EW 19U, closed basin of San Luis Valley. 

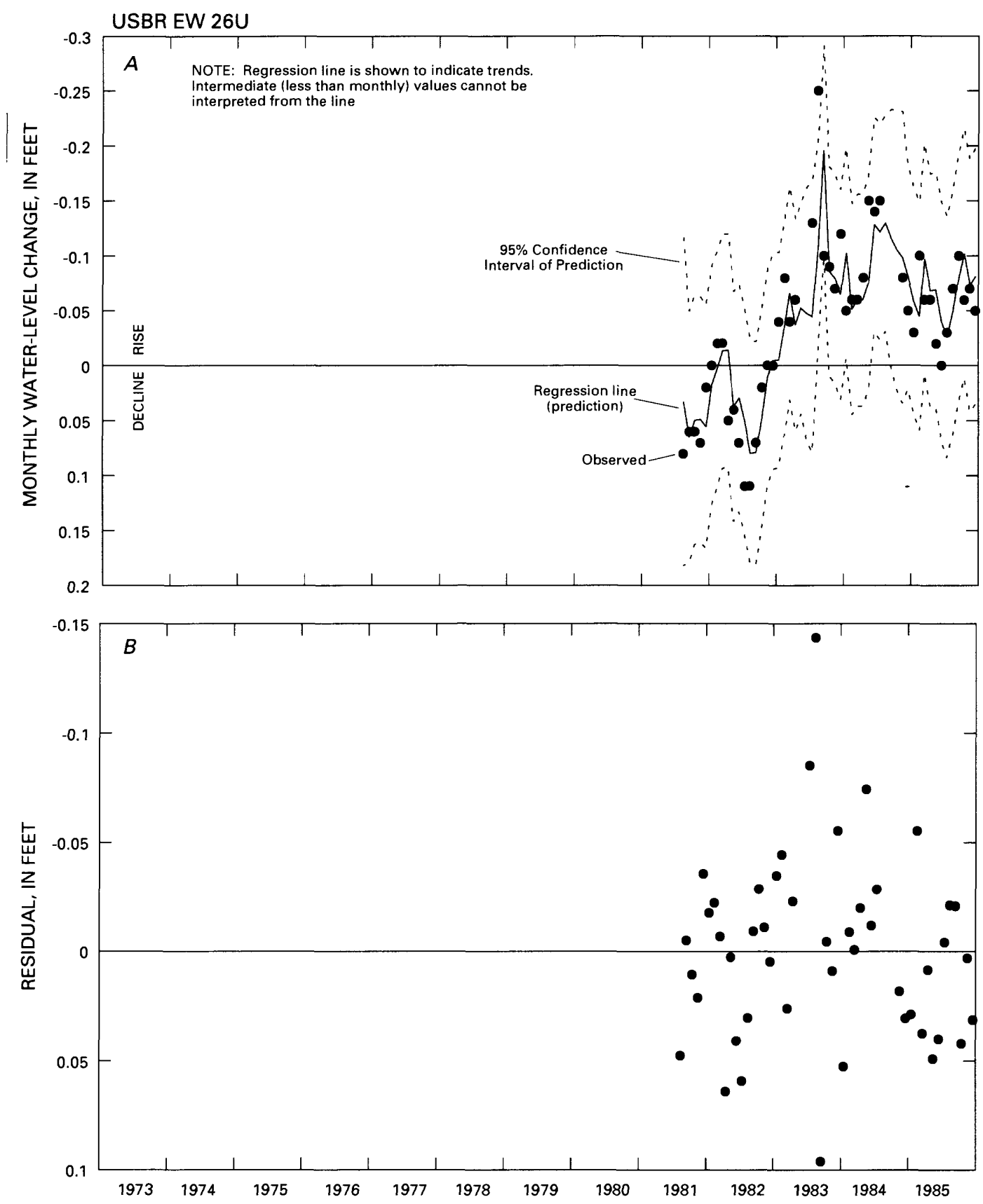

Figure 22. (A) Observed and predicted monthly water-level change and confidence limits; and (B) residual errors for observation well USBR EW 26U, closed basin of San Luis Valley. 

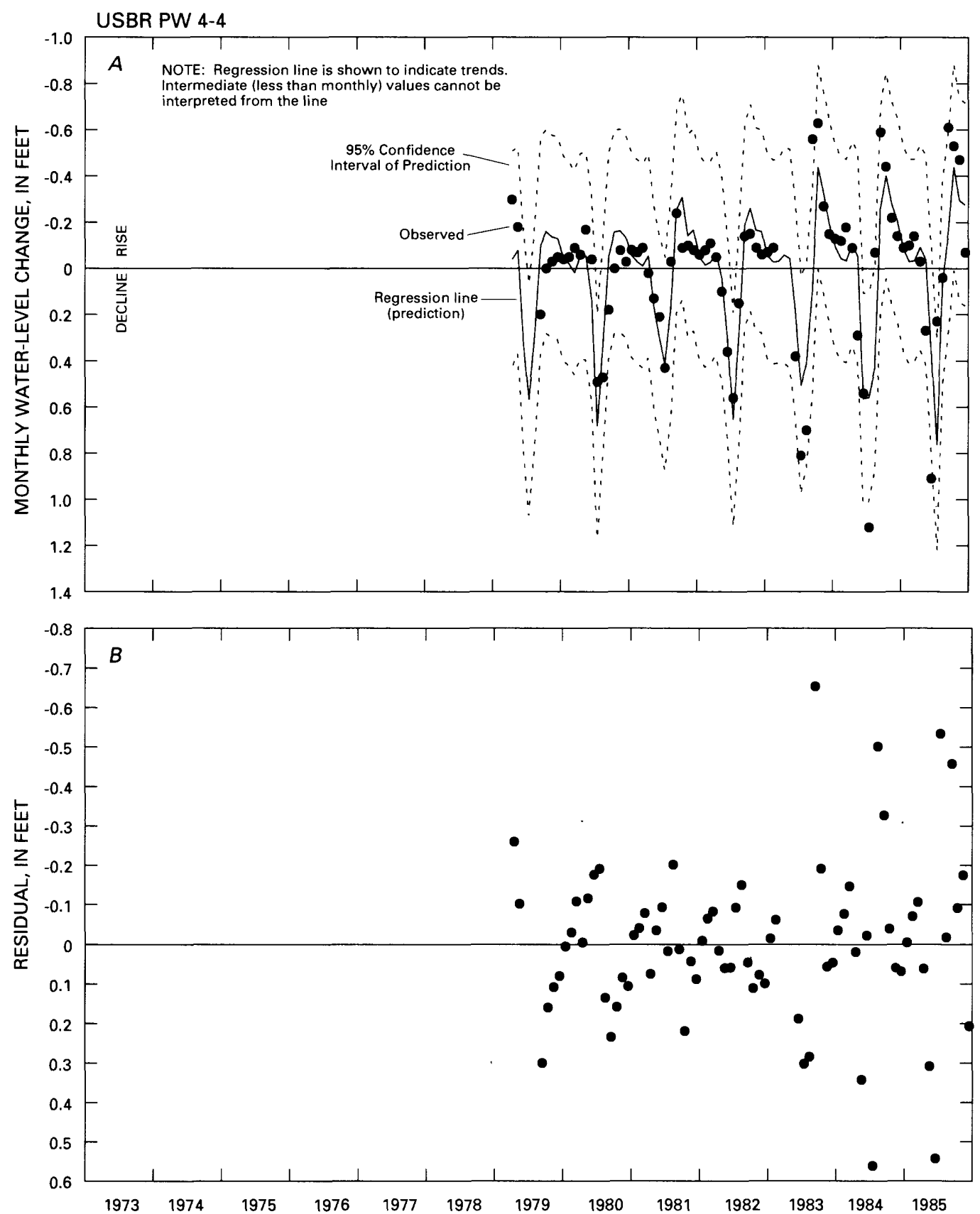

Figure 23. (A) Observed and predicted monthly water-level change and confidence limits; and (B) residual errors for observation well USBR PW 4-4, closed basin of San Luis Valley. 

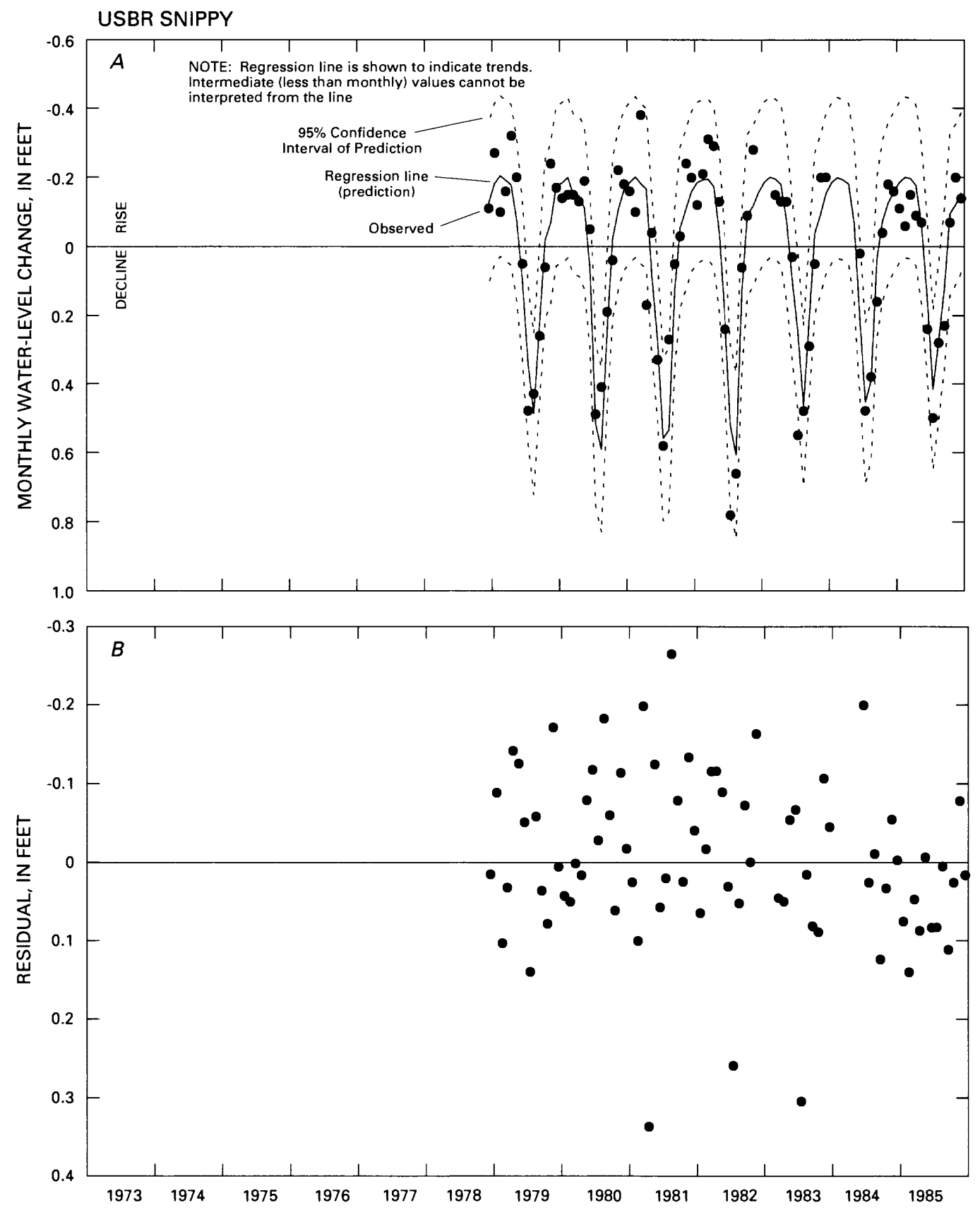

Figure 24. (A) Observed and predicted monthly water-level change and confidence limits; and (B) residual errors for observation well USBR SNIPPY, closed basin of San Luis Valley. 
Hydrographs of observed and predicted monthly water-level change for 9 selected wells are shown in figures 16 through 24 , and for the other 37 wells in figures B-1 through B-37 in Appendix B. Wells shown in figures 16 through 24 were selected to represent a wide geographic distribution and to represent typical responses in the study area. (Note: The scale for water-level change in figures 16 through 24 and B-1 through B-37 is defined so that water-level declines plot below zero, and water-level rises plot above zero.) Where the model statistics (table 5) indicate a lack of fit (relatively large $\mathrm{SE}_{\mathrm{e}}$ and relatively small $R_{a}{ }^{2}$-total), little of the variance in the response variable is explained by the model. Where the model statistics indicate a relatively good fit (relatively small $\mathrm{SE}_{\mathrm{e}}$ and relatively large $\mathrm{R}_{\mathrm{a}}{ }^{2}$-total), most of the variance in the response variable is explained by the regression model. Of the 5 regression models based on at least 100 observations, only the regression model for well RGWCD 23 had an $R_{a}{ }^{2}$-total of at least 0.5 . The wells with more than 100 monthly water-level change values generally are located in areas in which water levels may have been strongly affected by local recharge and discharge; for example, near drains, streams, or irrigation wells.

\section{PREDICTING POST-1985 MONTHLY WATER-LEVEL CHANGES WITH REGRESSION MODELS}

The regression models (table 5) can be used to predict post-1985 monthly water-level changes at the 46 selected observation wells for comparison with measured post-1985 monthly water-level changes. If a measured monthly water-level change is outside the 95-percent confidence limits, one can conclude that the change has been effected by conditions of recharge or discharge, or both, that differ from conditions that prevailed during the period of record on which the corresponding regression model is based. The differing conditions may be local or regional in scale.

A predicted monthly water-level change for an observation well can be computed, using the regression parameters listed in table 5 , if values for the firstand second-stage predictor variables used in the regression models are available. Computation of predicted monthly water-level change and of the upper and lower 95-percent confidence limits of prediction is most easily done by use of a statistical package and a computer, but also can be done manually.
A generalized second-stage regression model for prediction of monthly water-level change may be expressed as:

$$
\begin{aligned}
& \bar{S}_{i}=B_{0}+B_{T} T+B_{X_{c}} X_{c m}+B_{X_{s}} X_{s m}+B_{R P P} R P P_{i} \\
& +\mathrm{B}_{\mathrm{RTA}} \mathrm{RTA} ;+\mathrm{B}_{\mathrm{RRO}} \mathrm{RRO}_{\mathrm{i}}+\mathrm{B}_{\mathrm{RSW}} \mathrm{RSW}_{\mathrm{i}} \\
& +B_{R G W} R G W-a_{1}\left(S_{i-1}-\bar{S}_{i-1}\right) \text {, }
\end{aligned}
$$

where

$\overline{\mathrm{S}}_{\mathrm{i}}$ and $\overline{\mathrm{S}}_{\mathrm{i}-1}$ are the predicted water-level changes for months $i$ and $\mathrm{i}-1 ; \mathrm{B}_{0}, \mathrm{~B}_{\mathrm{T}}, \mathrm{B}_{\mathrm{X}_{\mathrm{c}}}, \mathrm{B}_{\mathrm{X}_{\mathrm{s}}}, \mathrm{B}_{\mathrm{RPP}} \mathrm{B}_{\mathrm{RTA}}$, $\mathrm{B}_{\mathrm{RRO}}, \mathrm{B}_{\mathrm{RSW}}$, and $\mathrm{B}_{\mathrm{RGW}}$ are the second-stage regression parameters; $X_{c m}, X_{s m}, R P P_{i}, R_{A} A_{i}, R R O_{i}$, $\mathrm{RSW}_{\mathrm{i}}$, and $\mathrm{RGW}_{\mathrm{i}}$ are the second-stage predictor variables; $a_{1}$ is the serial correlation coefficient; and $\mathrm{S}_{\mathrm{i}-1}$ is the observed water-level change for month $\mathrm{i}-1$. Because this model incorporates an autoregressive error term, it is an autoregressive model. Regression parameters for second-stage predictor variables that are not included in individual models are shown as zero in table 5. Similarly, for regression models that do not have serially correlated residuals, the serial correlation coefficient $\left(a_{1}\right)$ is zero. The 95-percent confidence limits can be calculated as follows:

$$
\begin{aligned}
& \text { upper limit }=\bar{S}_{i}+t_{\alpha / 2, n-p}\left[\operatorname{SE}_{e}^{2}\left(1+X_{i}^{\prime} \mathbf{V X} X_{i}\right)\right]^{1 / 2} \\
& \text { lower limit }=\bar{S}_{i}-t_{\alpha / 2, n-p}\left[\operatorname{SE}_{e}^{2}\left(1+X_{i}^{\prime} V X_{i}\right)\right]^{1 / 2}
\end{aligned}
$$

where

$$
\overline{\mathrm{S}}_{\mathbf{i}}=\text { predicted water-level change, in feet; }
$$

$t_{\alpha / 2, n-p}=$ student's $t$ statistic for $\alpha, n-p ;$

$\alpha$ = significance level;

n $=$ number of observations on which model is based;

p = number of (non-zero) regression parameters in model;

$\mathrm{SE}_{\mathrm{e}}=$ standard error of estimate;

$\mathbf{X}_{\mathbf{i}}=$ [1 1 T X $\mathrm{X}_{\mathrm{c}} \mathrm{X}_{\mathrm{s}}$ RPP RTA RRO RSW RGW e $\mathrm{e}_{\mathrm{i}-1}$ ];

$\mathbf{X}_{\mathbf{i}}^{\prime}=$ transpose of $\mathbf{X}_{\mathbf{i}}$; and

$V=a(p \times p)$ matrix calculated as the inverse of the product of $\mathbf{X}^{\prime}$ and $X$, where

$X=$ an $(n \times p)$ matrix of the values of the predictor variables and $\mathbf{X}^{\prime}$ is the transpose of $\mathbf{X}$. The $\mathbf{V}$ matrix for each regression model is listed in Appendix C.

As an example of use of one of the models, predicted monthly water-level change and the 95-percent confidence limits of prediction for observation well 
USBR SNIPPY for January $1986(\mathrm{i}=157, \mathrm{~m}=1)$ may be computed from the regression model for which parameters are listed in table 5 as:

$$
\bar{S}_{\mathrm{i}}=-0.013-0.167 \mathrm{X}_{\mathrm{cm}}-0.195 \mathrm{X}_{\mathrm{sm}}+0.024 \mathrm{RGW}_{\mathrm{i}}
$$

where

$$
\begin{aligned}
\overline{\mathrm{S}}_{\mathrm{i}} & =\text { predicted water-level change, in feet; } \\
\mathrm{i} & =157 \\
\mathrm{~m} & =1 ; \\
\mathrm{X}_{\mathrm{cm}} & =0.866 ; \\
\mathrm{X}_{\mathrm{sm}} & =0.5 ; \text { and } \\
\mathrm{RGW}_{157} & =2.90 \mathrm{gWh} .
\end{aligned}
$$

[Note: $\mathrm{RGW}_{157}=\mathrm{GW}_{157}-\overline{\mathrm{GW}}_{1}, \mathrm{GW}_{157}=$ $0.05 \mathrm{gWh}, \overline{\mathrm{GW}}_{1}=-2.85 \mathrm{gWh}$, from table 3; $\mathrm{RGW}_{157}=0.05-(-2.85)=2.90 \mathrm{gWh}$.]

For this example,

$$
\begin{aligned}
\bar{S}_{157}= & -0.013-0.167(0.866)-0.195(0.5) \\
& +0.024(2.90), \\
\bar{S}_{157}= & -0.186 \mathrm{ft}, \text { a water-level rise. }
\end{aligned}
$$

The 95-percent confidence interval for this example is calculated as:

$$
\begin{aligned}
& S_{i} \geq \bar{S}_{i}-t_{\alpha / 2, n-p}\left[\operatorname{SE}_{\mathrm{e}}^{2}\left(1+X_{157}^{\prime} V X_{157}\right)\right]^{1 / 2} \\
& S_{i} \leq \bar{S}_{i}+t_{\alpha / 2, n-p}\left[{S E_{e}}^{2}\left(1+X_{157}^{\prime} V X_{157}\right)\right]^{1 / 2}
\end{aligned}
$$

where

$$
\begin{aligned}
& t_{\alpha / 2, n-p}=2.00 \text { for } \alpha=0.05 \text {, and } n-p=74 \text {; } \\
& \mathrm{SE}_{\mathrm{e}}=0.114 \text {, in feet; } \\
& \mathrm{X}_{157}=\left[\begin{array}{llll}
1 & 0.866 & 0.5 & 2.90
\end{array}\right] ; \text { and }
\end{aligned}
$$

$$
\mathbf{X}_{157}^{\prime}=\left[\begin{array}{l}
1 \\
0.866 \\
0.5 \\
2.90
\end{array}\right]
$$

V matrix for USBR SNIPPY from Appendix C is:

$$
V=\left[\begin{array}{rrrr}
0.0001732855 & -0.0000074462 & 0.0000183419 & -0.0000060730 \\
-0.0000074462 & 0.0003470687 & 0.0000240450 & 0.0000119798 \\
0.0000183419 & 0.0000240450 & 0.0003506743 & 0.0000073374 \\
-0.0000060730 & 0.0000119798 & 0.0000073374 & 0.0000070180
\end{array}\right]
$$

$X_{157}^{\prime} V X_{157}=0.00064$

$$
\begin{aligned}
& S_{i} \geq-0.186-2.00[0.013(1+0.00064)]^{1 / 2}=-0.414 \mathrm{ft}, \\
& S_{i} \leq-0.186+2.00[0.013(1+0.00064)]^{1 / 2}=0.042 \mathrm{ft} .
\end{aligned}
$$

The 95-percent confidence limits for the prediction of $\bar{S}_{157}=-0.186 \mathrm{ft}$ are -0.414 and $0.042 \mathrm{ft}$. A measured value of water-level change outside the 95-percent confidence interval might indicate a change in local recharge or discharge conditions, or both, near USBR SNIPPY. The actual value for water-level change $\left(S_{157}\right)$ at USBR SNIPPY from December 1985 to January 1986 was $-0.14 \mathrm{ft}$, which is within $0.046 \mathrm{ft}$ of the predicted value and is well within the 95-percent confidence interval of -0.414 to $0.042 \mathrm{ft}$.

If the water-level changes (drawdown) outside the boundaries of the Closed Basin Division are equal to or larger than those at boundary wells, then withdrawals outside the Closed Basin Division probably are at least partially responsible for changes at the boundary. Twenty-one of the selected observation wells are completed in the unconfined aquifer and are located within $1 \mathrm{mi}$ of the boundary of the Closed Basin Division (pl. 1). These 21 observation wells can be considered to be index wells for monitoring waterlevel change in the unconfined aquifer at or near the boundary. These index wells are: RGWCD 15, 23, 42, and 45A, and USBR EW 2U, EW 9U, EW 11U, EW 12U, EW 14U, EW 16U, EW 19U, EW 20U, EW 21U, EW 23U, EW 24U, EW 26U, EW 33U, EW 35U, EW 39U, PW 5-2, and SNIPPY. Similarly, eight of the selected observation wells are completed below confining units and are within $1 \mathrm{mi}$ of the boundary (pl. 1). These index wells are: USBR EW 22C, EW 33C, EW 35C, EW 39C, PW 1-7, PW 2-4, PW 2-5, and PW 4-4.

\section{LIMITATIONS AND USE OF THE MODELS}

The regression models developed in this study can be used to predict monthly water-level change if data for the predictor variables are available. Comparison of predicted water-level change with measured changes provides a basis for deciding if a water-level change is larger than would normally be expected. Most (39) of the regression models have standard errors of estimate less than $0.5 \mathrm{ft}$, and confidence intervals of prediction for these models are relatively small. Regression models with $\mathrm{R}_{\mathrm{a}}{ }^{2}$ near 1 and small standard error are the best predictors of water-level change. In general, the regression models that are based on relatively short periods of record are less likely to accurately predict future water-level changes than models based on longer periods of record. The accuracy of predicted water-level changes also likely will be 
decreased in instances in which one or more values of predictor variables are outside the ranges of those variables on which the particular regression model is based.

The accuracy of the predictive models developed for this report is limited by the following factors: (1) The period of record for most observation wells is relatively short, less than 50 months prior to 1986; (2) data within the time series of water levels are missing; and (3) data to define local variation in recharge and discharge are not available. If detailed information on recharge and discharge, particularly ground-water pumpage, is collected, then deterministic analytical or numerical methods may provide more accurate predictions of water-level change.

\section{SUMMARY}

Water-level declines that result from withdrawal of unconfined ground water in the Closed Basin Division of the San Luis Valley are limited by the legislation that authorized the project to a maximum of $2 \mathrm{ft}$ in irrigation or domestic wells outside the boundaries of the Closed Basin Division that existed prior to construction of the Closed Basin Division. Long-term and seasonal water-level changes in the area around and in the Closed Basin Division during 1973-85, a period that predates extensive withdrawals by the Closed Basin Division, have been greater than $2 \mathrm{ft}$ in most of the Closed Basin Division study area. The average monthly water-level change at eight wells with more than 80 months of record during 1973-85 was a rise of $-0.027 \mathrm{ft}$. These water-level changes can be related to temporal and spatial variations in surfacewater supply, ground-water pumpage, and natural variation in climatically controlled recharge and discharge conditions. A two-stage process was used to develop regression models to predict monthly water-level change in 46 selected observation wells in or near the Closed Basin Division. In the first stage, harmonic functions with an annual period were used as predictor variables in regression models of precipitation, mean air temperature, discharge of Saguache Creek, monthly streamflow depletion of the Rio Grande, and electric power usage for agricultural purposes. In the second stage, elapsed time, annual-period harmonic functions, and residuals from the first-stage models were used as predictor variables in regression models of monthly water-level change.
The adjusted coefficients of determination of the regression equations range from 0.08 to 0.89 . The standard errors of estimate of the models are less than $0.1 \mathrm{ft}$ for 14 models and is more than $1 \mathrm{ft}$ for 5 wells; this statistic ranges from 0.034 to $0.50 \mathrm{ft}$ for 39 of the regression models. Autoregressive methods were used in $\mathbf{2 4}$ of the models to decrease serial correlation in the residuals. The regression models shown in this report can be used to predict future monthly water-level changes. A method for calculating the 95-percent confidence interval for predicted values also is shown. If actual water-level changes are outside the 95-percent confidence interval of predicted water-level change, then changes in regional recharge or discharge conditions, or both, or in local recharge or discharge conditions, or both (such as withdrawals by nearby salvage or irrigation wells), may have affected the water levels.

\section{REFERENCES}

Crouch, T.M., 1985, Potentiometric surface, 1980, and water-level changes, 1969-80, in the unconfined valley-fill aquifers of the San Luis Basin, Colorado and New Mexico: U.S. Geological Survey Hydrologic Atlas HA-683, scale 1:250,000, 2 sheets.

Davis Engineering Services, Inc., 1983, Map of the San Luis Valley, Colorado, showing sprinkler locations, approximate limit of alluvial fill, and approximate location of the hydraulic divide: Del Norte, Colo., scale 1:125,000.

Draper, N.R., and Smith, H., 1981, Applied regression analysis (2d ed.): New York, John Wiley, 709 p.

Emery, P.A., 1970, Electric analog model evaluation of a water-salvage plan, San Luis Valley, south-central Colorado: Colorado Water Conservation Board Circular 14, 11 p.

Emery, P.A., Snipes, R.J., and Dumeyer, J.M., 1972, Hydrologic data for the San Luis Valley, Colorado: Colorado Water Conservation Board Basic-Data Release 22, $146 \mathrm{p}$.

Emery, P.A., Snipes, R.J., Dumeyer, J. M., and Klein, J.M., 1973, Water in the San Luis Valley, south-central Colorado: Colorado Water Conservation Board Circular 18, 26 p.

Emery, P.A., Patten, E.P., Jr., and Moore, J.E., 1975, Analog model study of the hydrology of the San Luis Valley, south-central Colorado: Colorado Water Conservation Board Circular 29, 21 p.

Hearne, G.A., and Dewey, J.D., 1988, Hydrologic analysis of the Rio Grande Basin north of Embudo, New Mexico; Colorado and New Mexico: U.S. Geological Survey Water-Resources Investigations Report 86-4113, 244 p. 
Hodgson, F.D.I., 1978, The use of multiple-linear regression in simulating ground-water level responses: Ground Water, v. 16 , no. 4 , p. 249-253.

Houston, J.F.T., 1983, Ground-water systems simulation by time-series techniques: Ground Water, v. 21, no. 3, p. 301-310.

HRS Water Consultants, Inc., and Moran, R.E., 1987, Interim task 2 report, data and information synthesis and needs, appendixes, San Luis Valley confined aquifer study, phase 1: Lakewood, Colo., HRS Water Consultants, Inc.

Huntley, D.L., 1979, Ground-water recharge to the aquifers of northern San Luis Valley, Colorado: Geological Society of America Bulletin, v. 90 , no. 8, part II, p. 1196-1281.

Jackson, R.E., 1973, Evapotranspiration of groundwaterA time series analysis of the hydrologic regimen of a groundwater discharge area: Environment Canada, Inland Waters Directorate, Water Resources Branch, Scientific Series 17, 40 p.

Leonard, G.J., and Watts, K.R., 1989, Hydrogeology and simulated effects of ground-water development on an unconfined aquifer in the Closed Basin Division, San Luis Valley, Colorado: U.S. Geological Survey Water-Resources Investigations Report 87-4284, $41 \mathrm{p}$.
Mallows, C.L., 1973, Some comments on Cp: Technometrics, v. 15, p. $661-675$.

Montgomery, D.C., and Peck, E.A., 1982, Introduction to linear regression analysis: New York, John Wiley, 504 p.

National Oceanic and Atmospheric Administration, 1973-85, National Climatological Center monthly report; available only at Asheville, N.C.

Powell, W.J., 1958, Ground-water resources of the San Luis Valley, Colorado: U.S. Geological Survey Water-Supply Paper 1379, 284 p.

SAS Institute Inc., 1985, SAS user guide-Statistics, version 5 (5th ed.): Cary, N.C., SAS Institute Inc., $956 \mathrm{p}$. 1988, SAS/ETS user's guide, version 6 (1st ed.): Cary, N.C., SAS Institute Inc., 560 p.

Siebenthal, C.E., 1910, Geology and water resources of the San Luis Valley, Colorado: U.S. Geological Survey Water-Supply Paper 240, 128 p.

Tasker, G.D., and Guswa, J.H., 1978, Application of a mathematical model to estimate water levels: Ground Water, v. 16 , no. 1 , p. 18-21.

Wonnacott, T.H., and Wonnacott, R.J., 1984, Introductory statistics for business and economics (3d ed.): New York, John Wiley, 746 p. 


\section{APPENDIXES}




\section{Appendix A-System of Numbering Wells}

The well locations in this report are given numbers based on the Bureau of Land Management system of land subdivision and show the location of the well by quadrant, township, range, section, and position within the section (fig. A-1). The first letter S preceding the location number indicates that the well is located in the area governed by the Sixth Principal Meridian. The second letter indicates the quadrant in which the well is located. Four quadrants are formed by the intersection of the base line and the principal meridian-the letter $A$ indicates the northeast quadrant, $B$ the northwest, $C$ the southwest, and D the southeast.

The first three digits of the number indicate the township, the next three digits the range, and the last two digits the section in which the well is located. The letters following the section number locate the well within the section. The first letter denotes the quarter section, the second letter the quarter-quarter section, and the third letter the quarter-quarter-quarter section. The letters are assigned in a counterclockwise direction, beginning with (A) in the northeast section and within each quarter-quarter section in the same manner. Where two or more locations are within the smallest subdivision, consecutive numbers beginning with 1 are added in the order in which data from the wells were collected. 


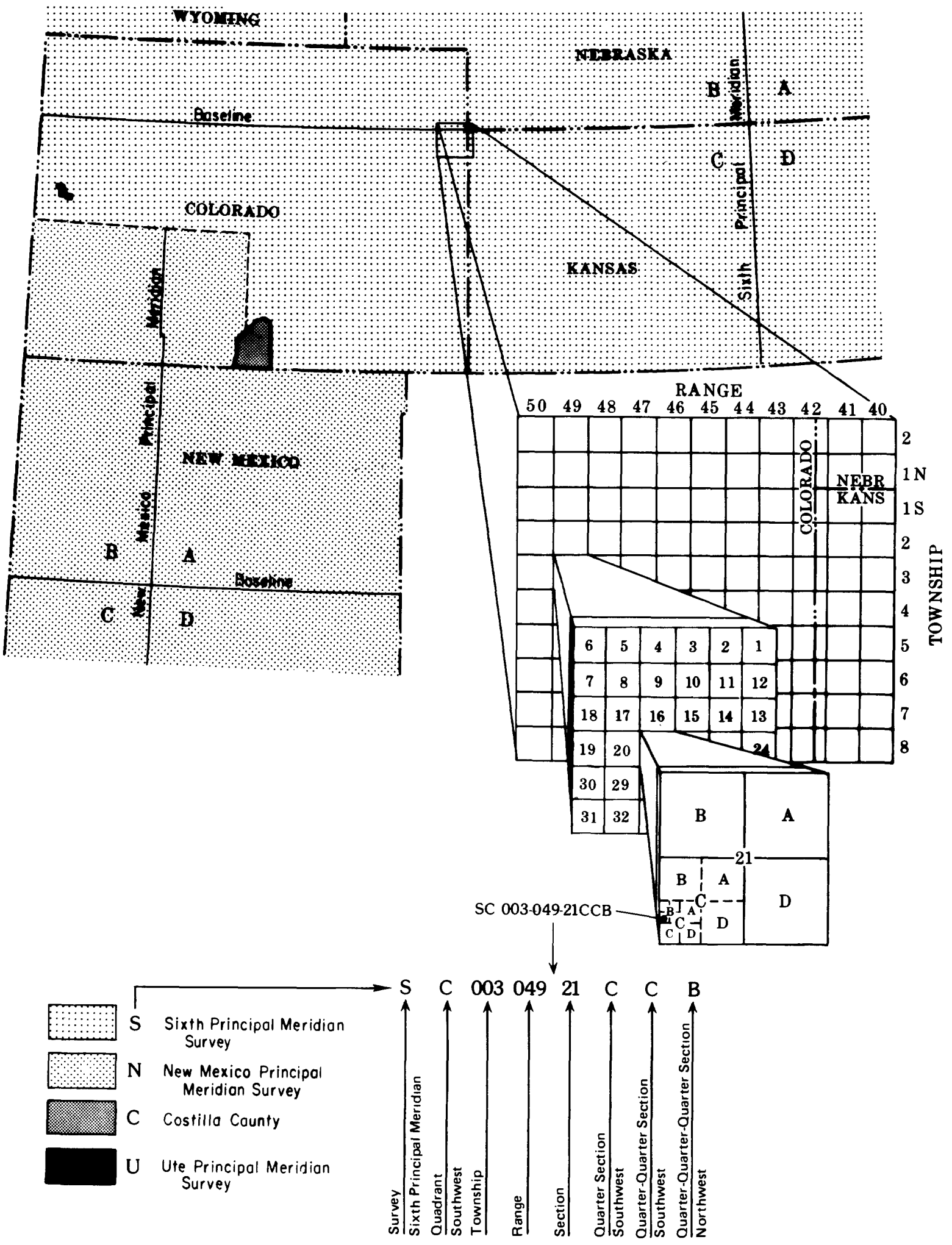

Figure A-1. System of numbering wells in Colorado. 
Appendix B-Hydrographs of Observed and Predicted Water-Level Change, Upper and Lower Confidence Limits, and Residual Errors for Selected Observation Weils in the Closed Basin Division Study Area 

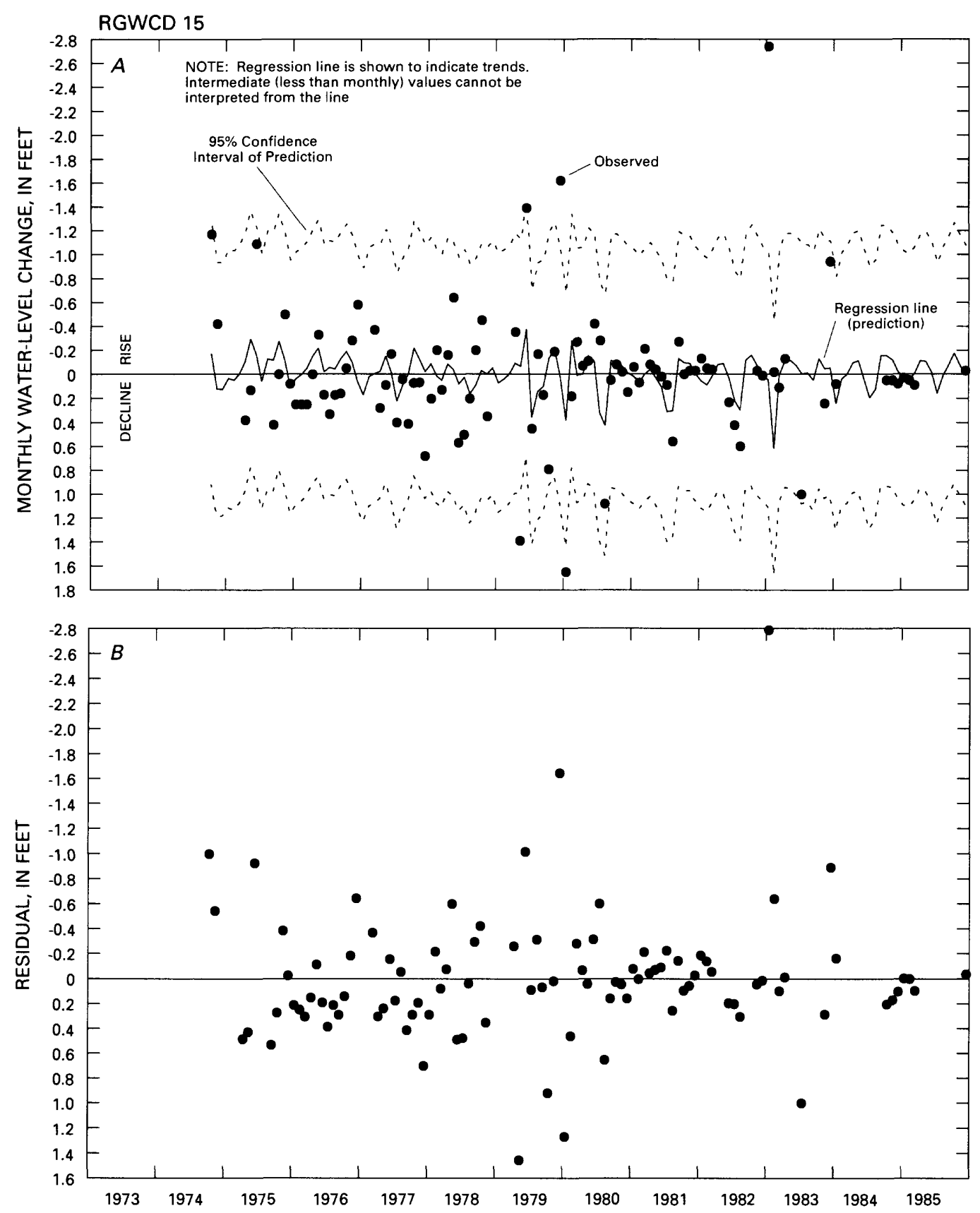

Figure B-1. (A) Observed and predicted water-level change and confidence limits; and (B) residual errors for observation well RGWCD 15, closed basin of San Luis Valley. 


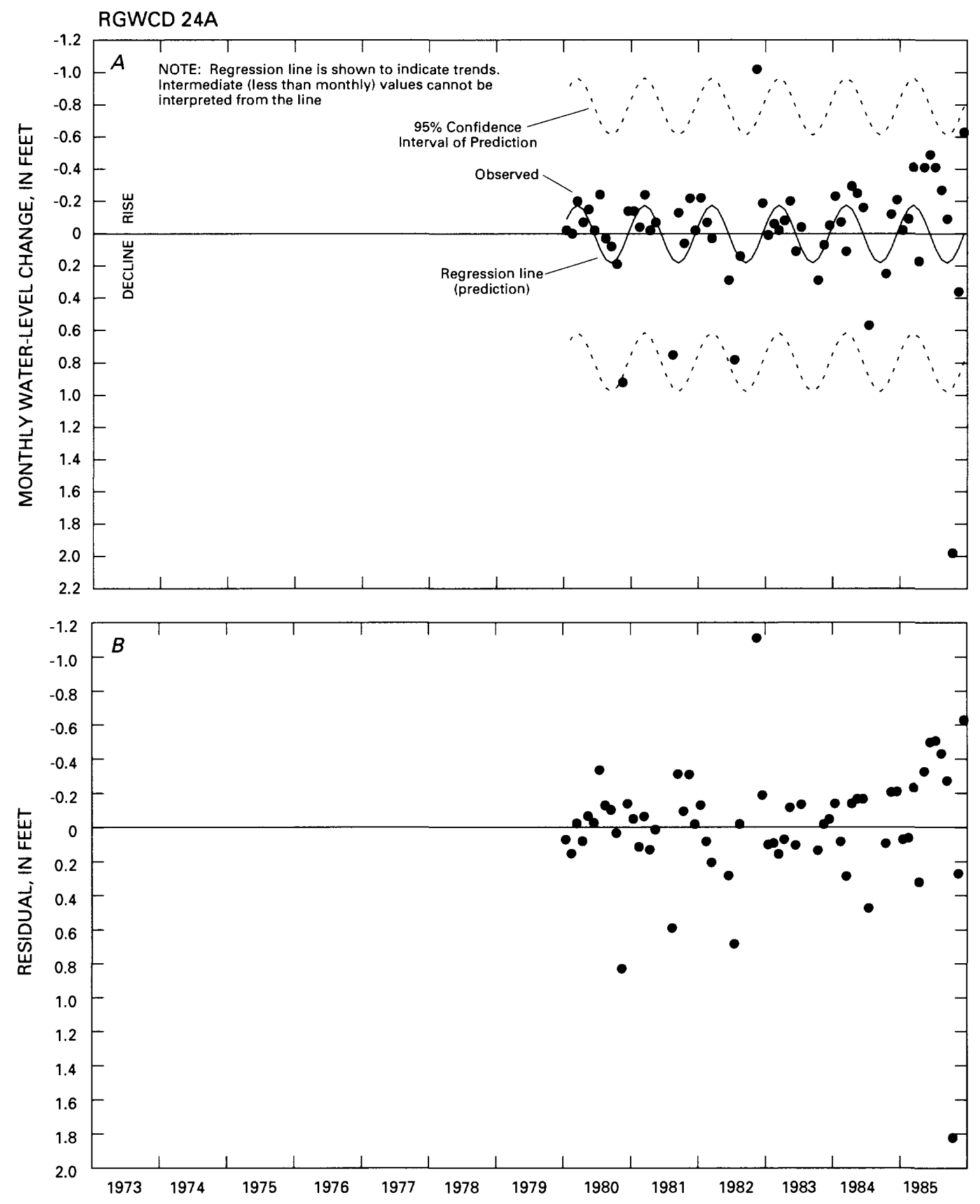

Figure B-2. (A) Observed and predicted water-level change and confidence limits; and (B) residual errors for observation well RGWCD 24A, closed basin of San Luis Valley. 

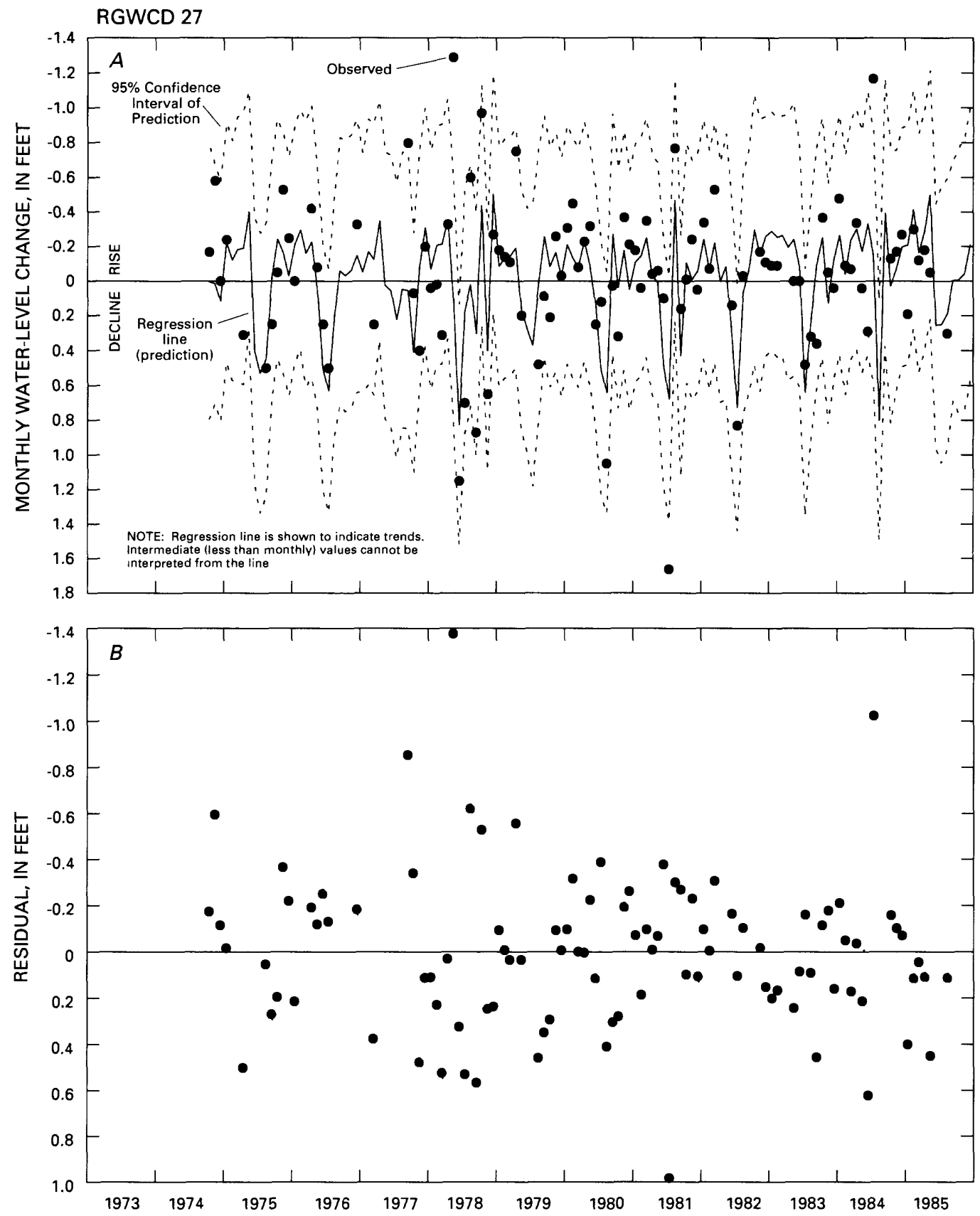

Figure B-3. (A) Observed and predicted water-level change and confidence limits; and (B) residual errors for observation well RGWCD 27, closed basin of San Luis Valley. 

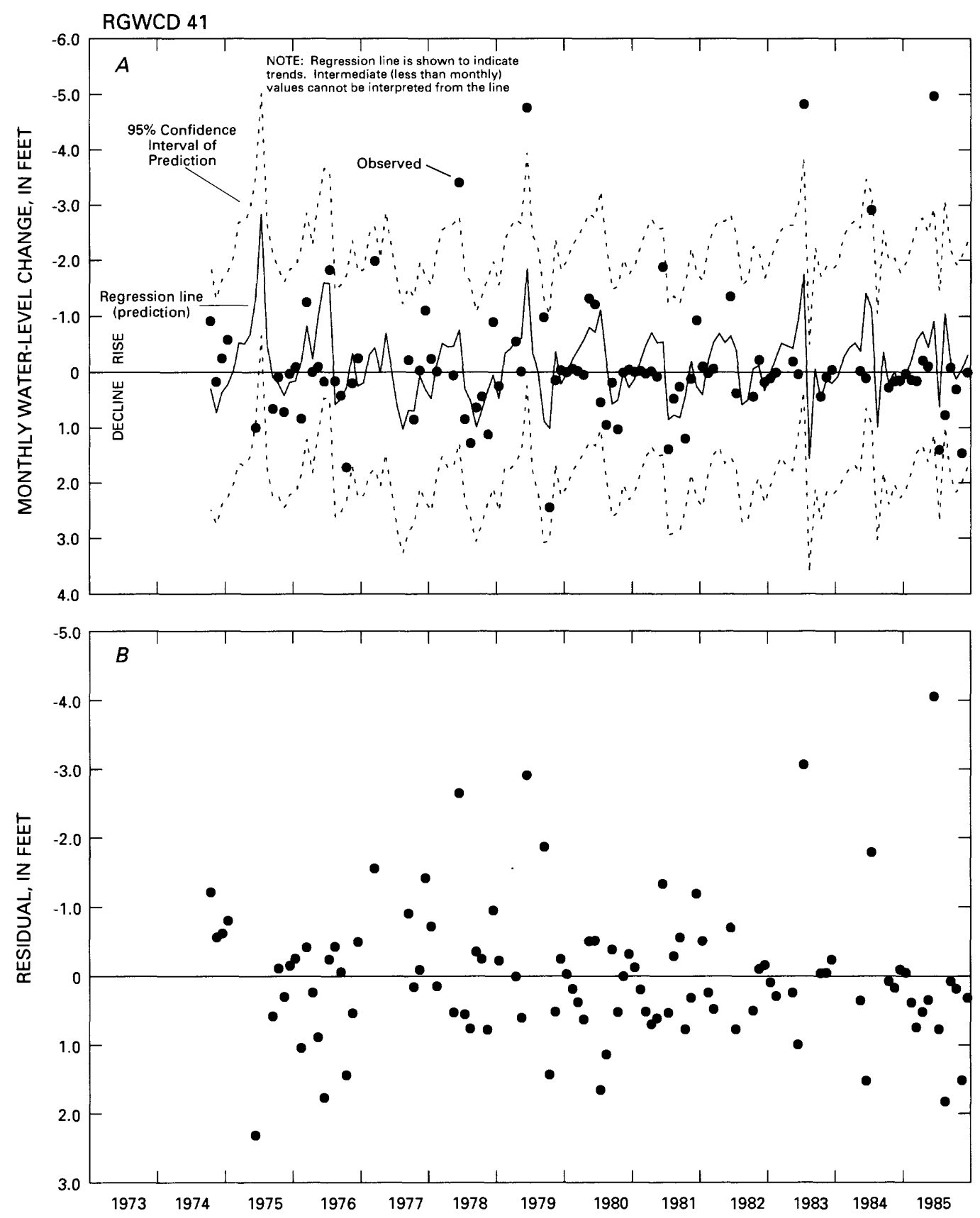

Figure B-4. (A) Observed and predicted water-level change and confidence limits; and (B) residual errors for observation well RGWCD 41, closed basin of San Luis Valley. 

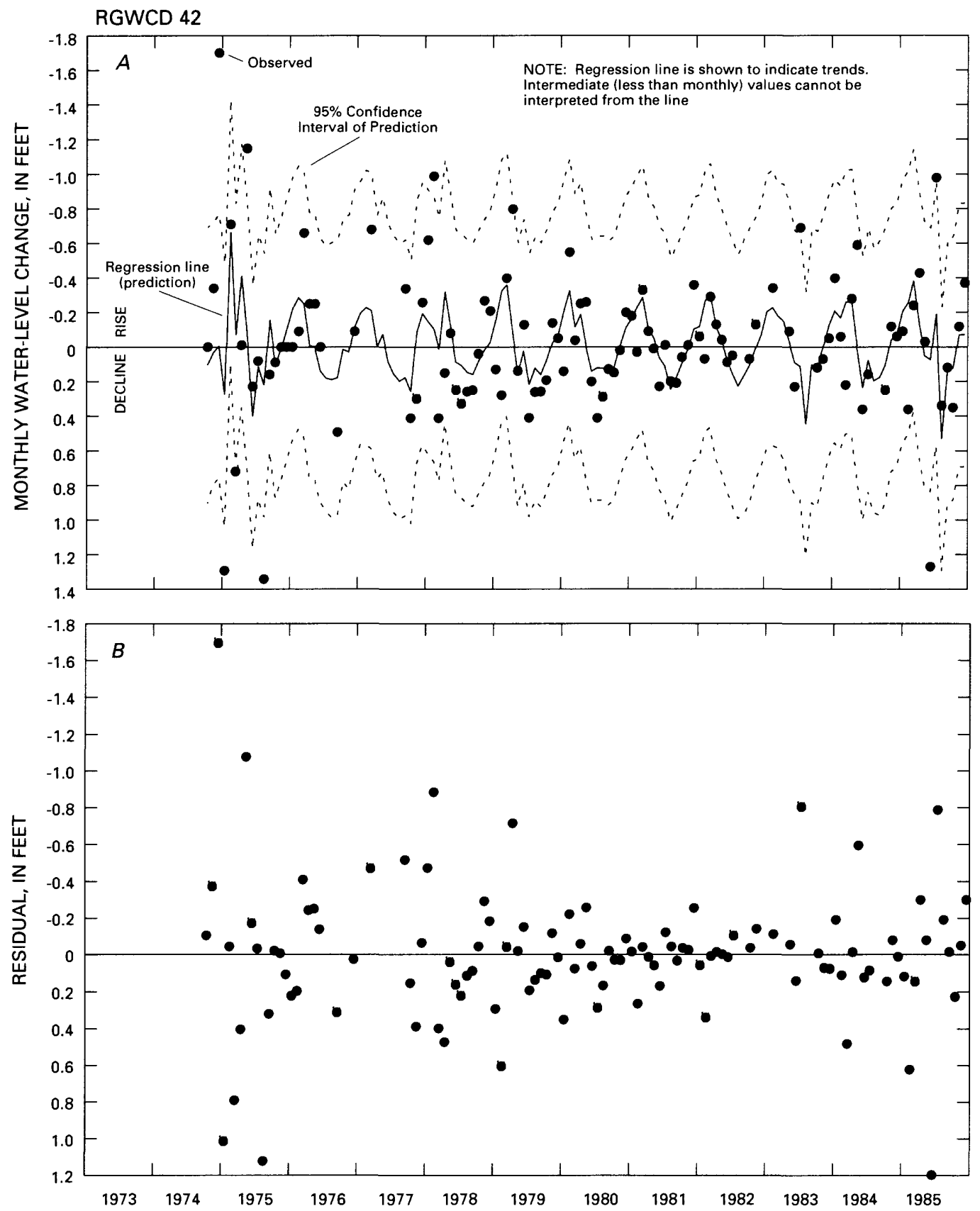

Figure B-5. (A) Observed and predicted water-level change and confidence limits; and (B) residual errors for observation well RGWCD 42, closed basin of San Luis Valley. 

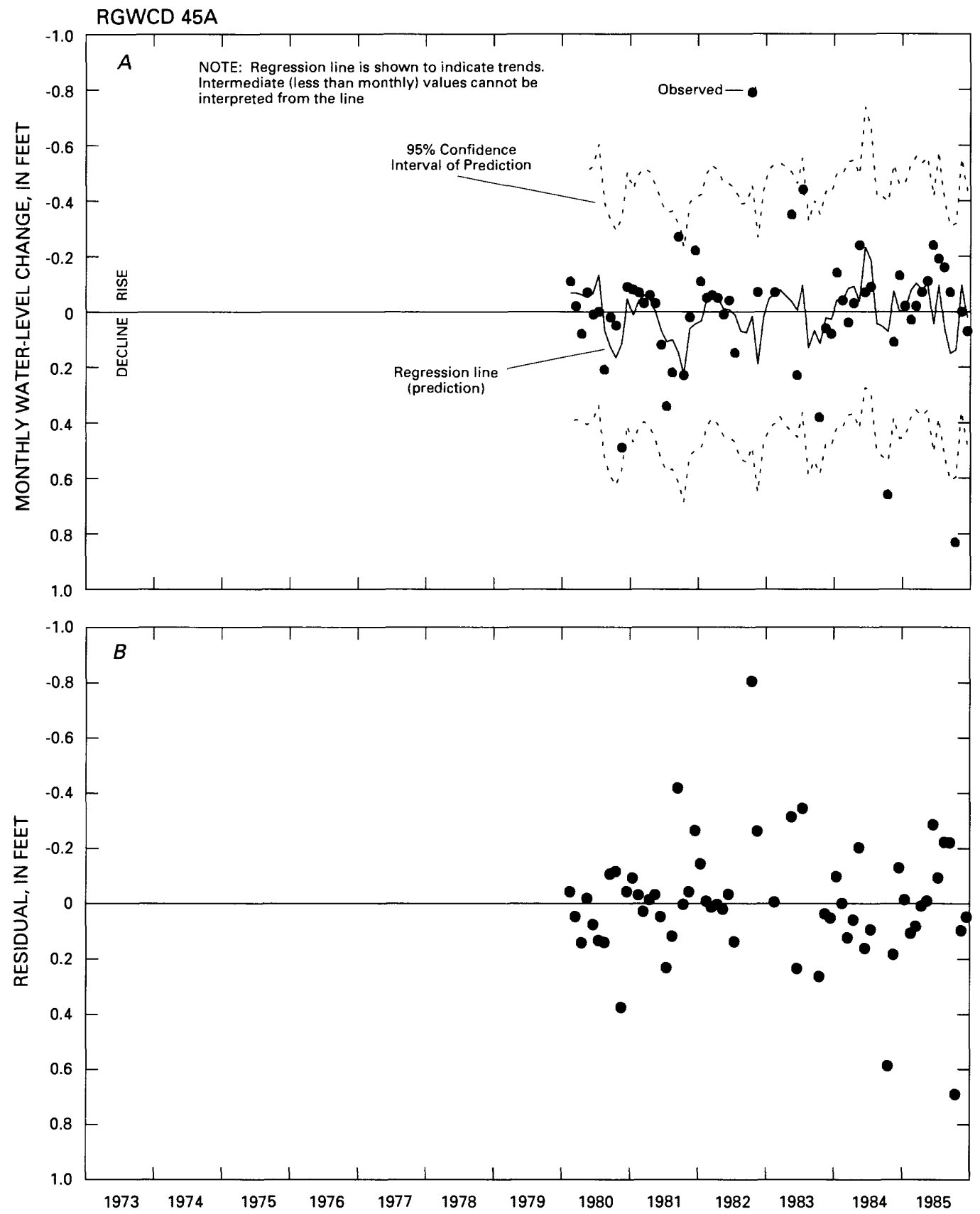

Figure B-6. (A) Observed and predicted water-level change and confidence limits; and (B) residual errors for observation well RGWCD 45A, closed basin of San Luis Valley. 

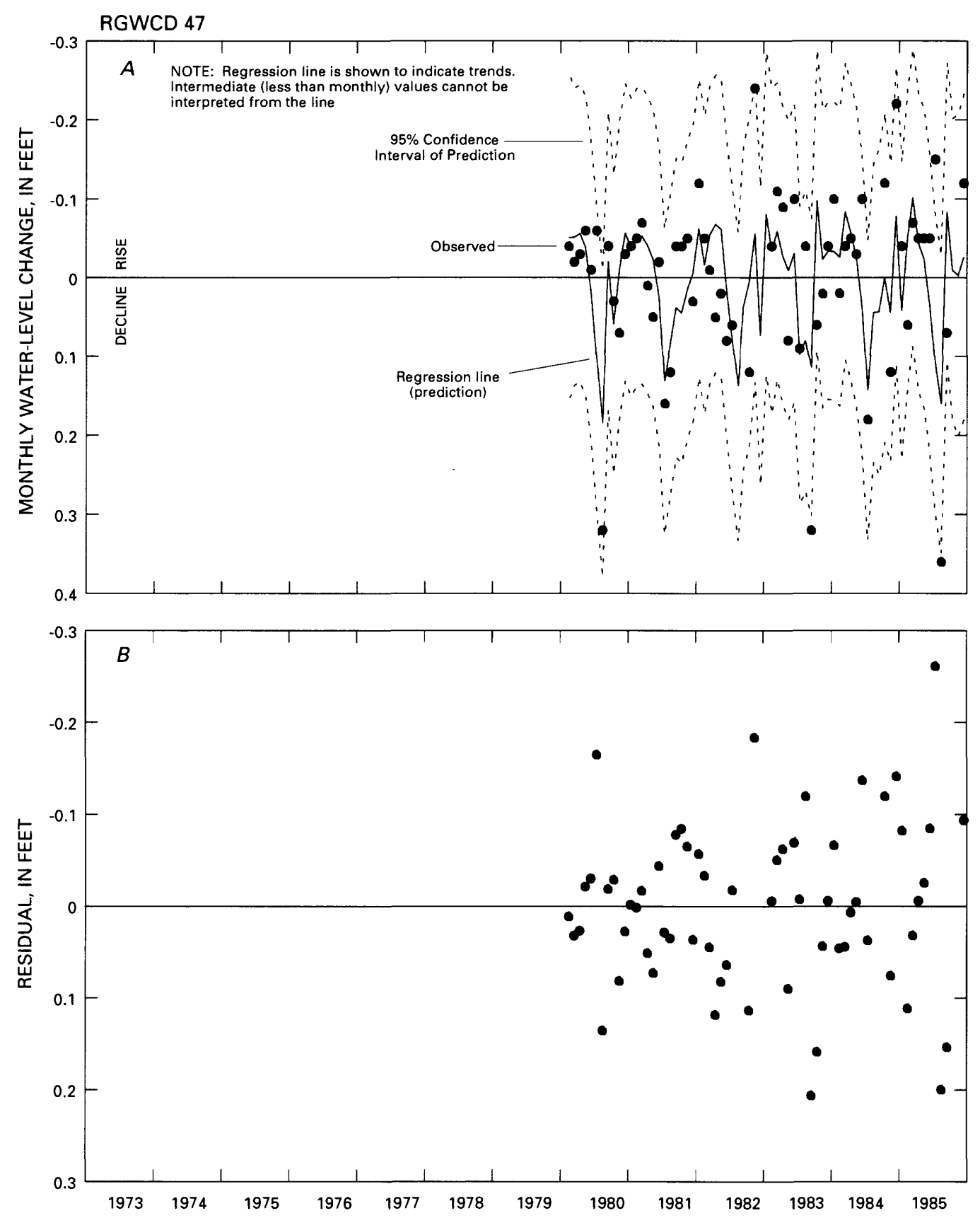

Flgure B-7. (A) Observed and predicted water-level change and confidence limits; and (B) residual errors for observation well RGWCD 47, closed basin of San Luis Valley. 

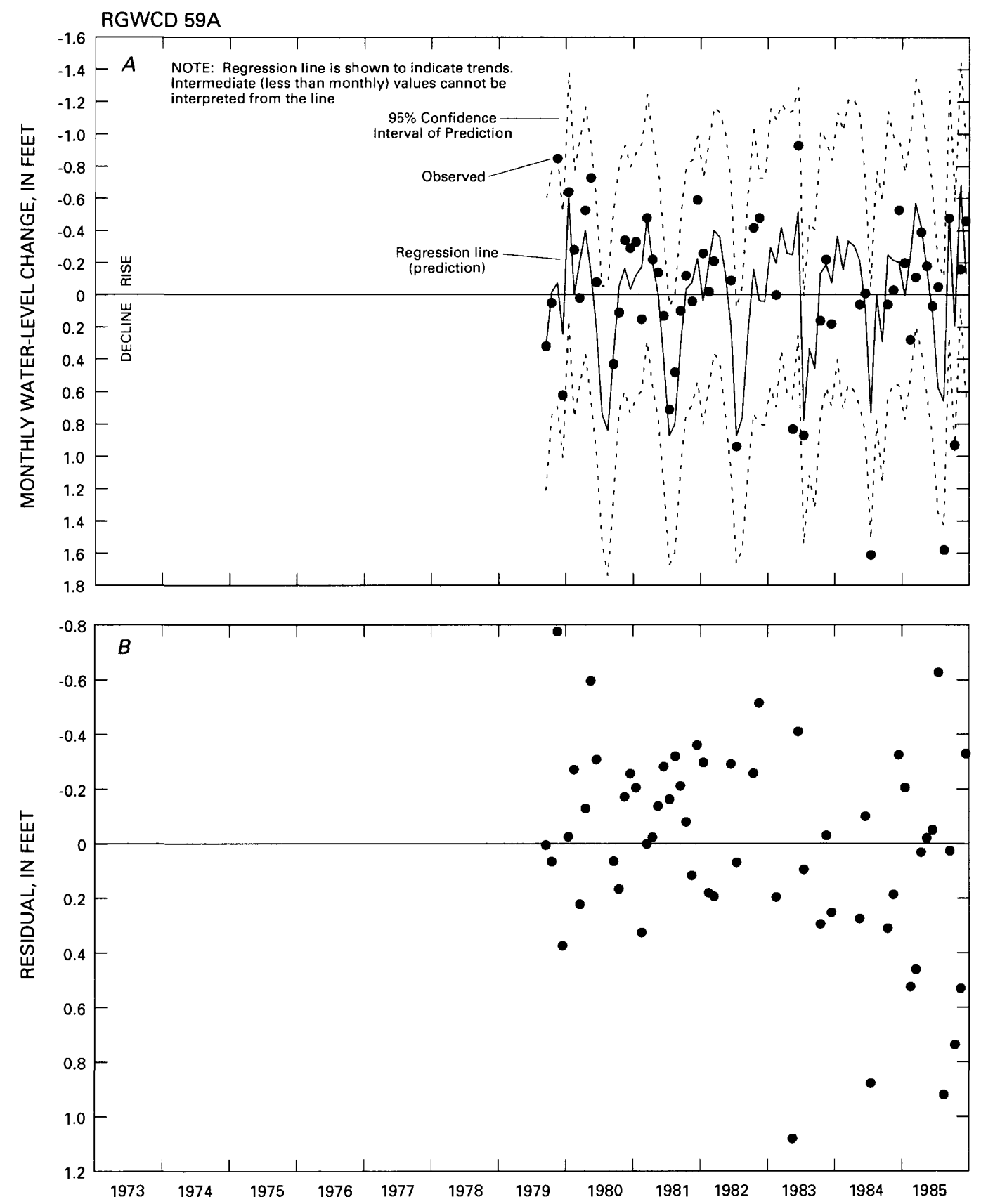

Figure B-8. (A) Observed and predicted water-level change and confidence limits; and (B) residual errors for observation well RGWCD 59A, closed basin of San Luis Valley. 

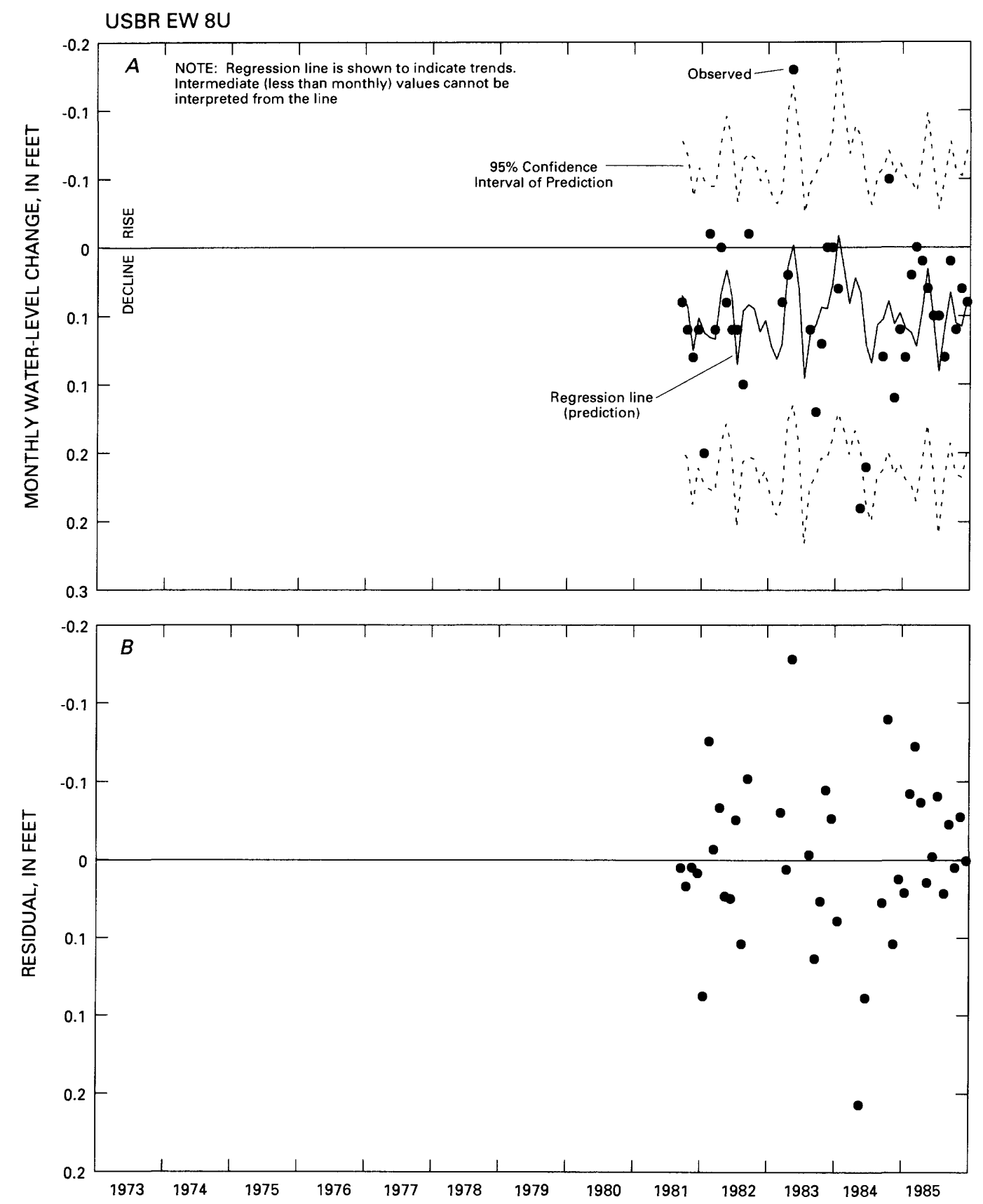

Figure B-9. (A) Observed and predicted water-level change and confidence limits; and (B) residual errors for observation well USBR EW $8 \mathrm{U}$, closed basin of San Luis Valley. 

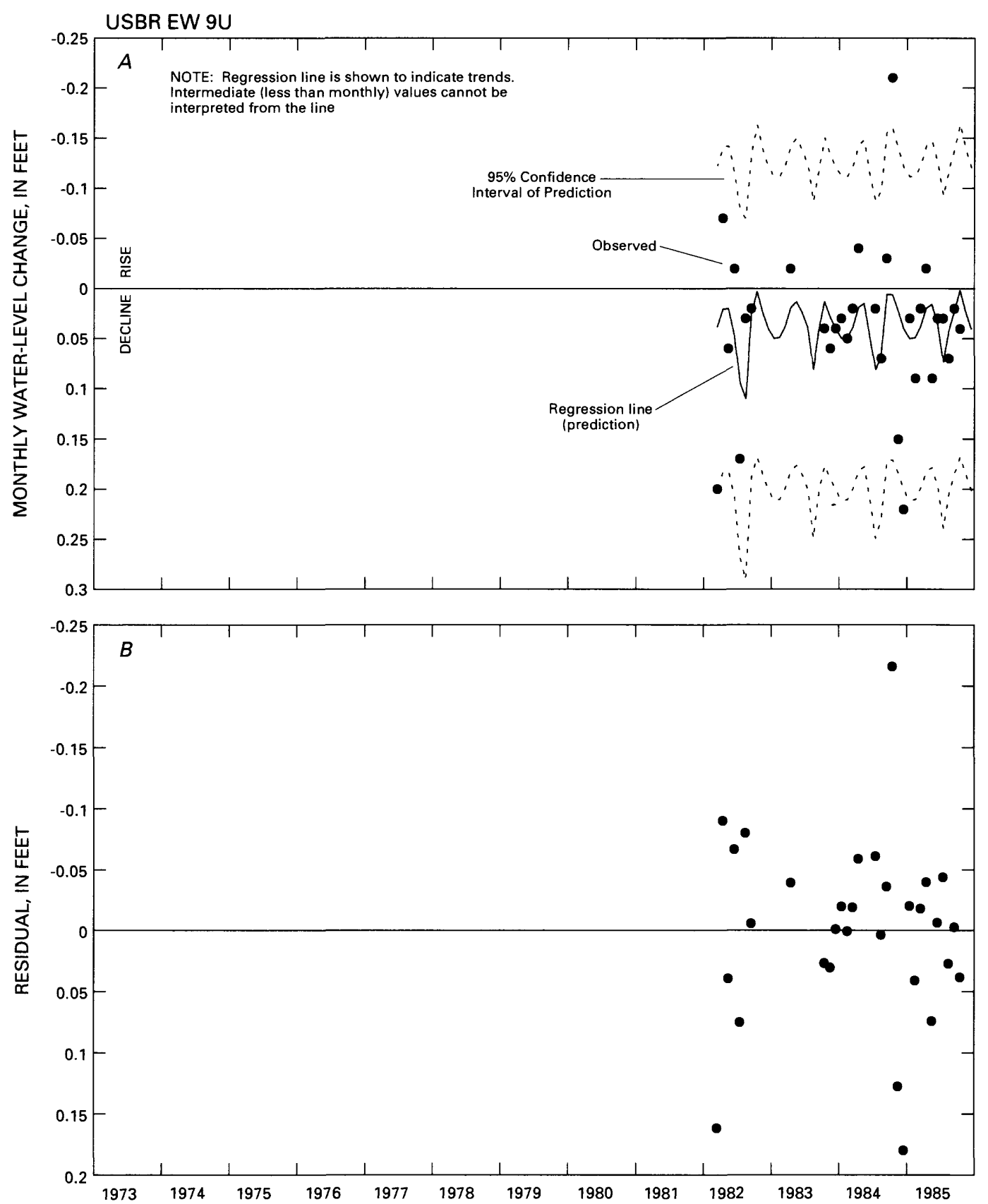

Figure B-10. (A) Observed and predicted water-level change and confidence limits; and (B) residual errors for observation well USBR EW 9U, closed basin of San Luis Valley. 

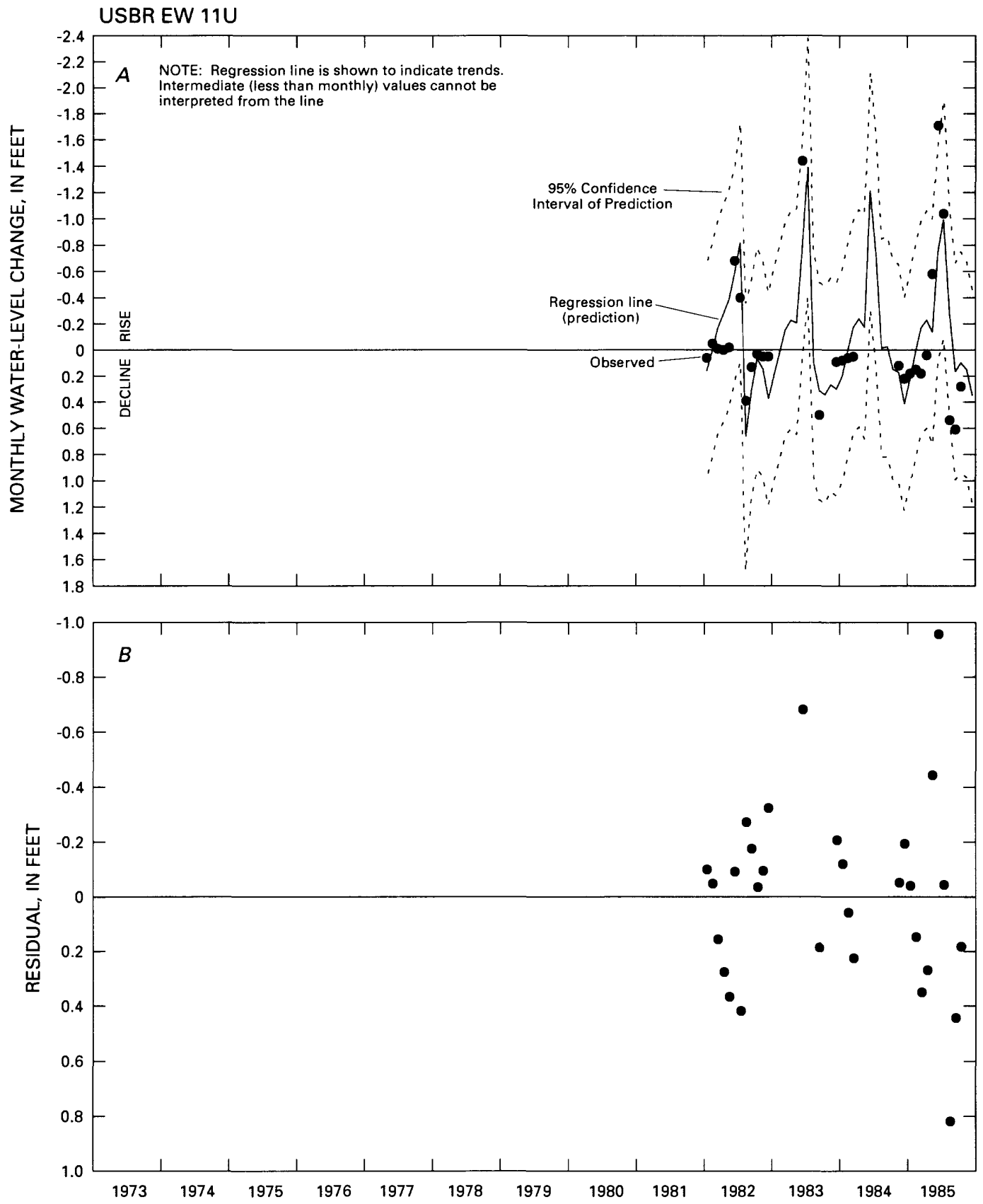

Figure B-11. (A) Observed and predicted water-level change and confidence limits; and (B) residual errors for observation well USBR EW 11U, closed basin of San Luis Valley. 

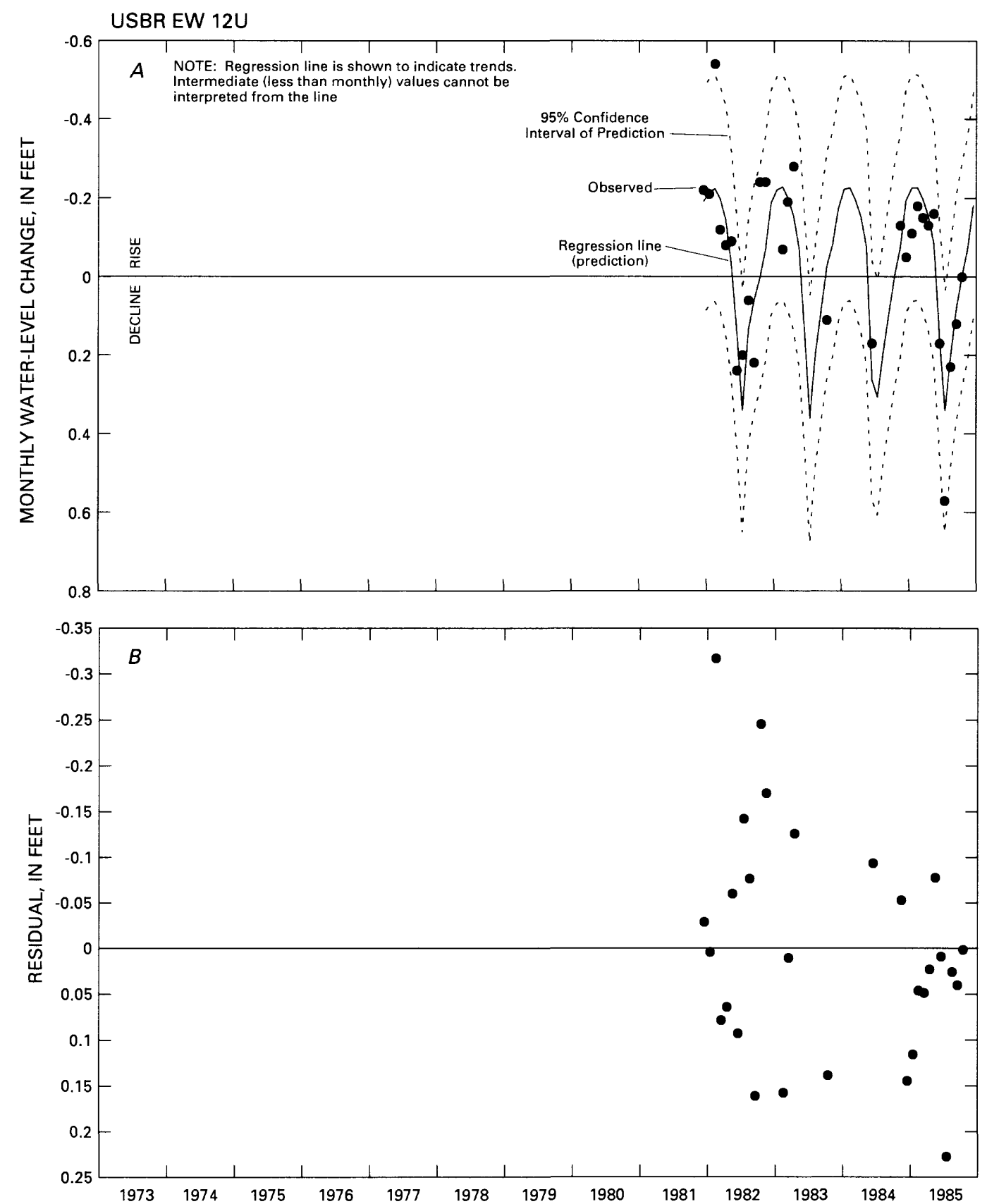

Figure B-12. (A) Observed and predicted water-level change and confidence limits; and (B) residual errors for observation well USBR EW 12U, closed basin of San Luis Valley. 

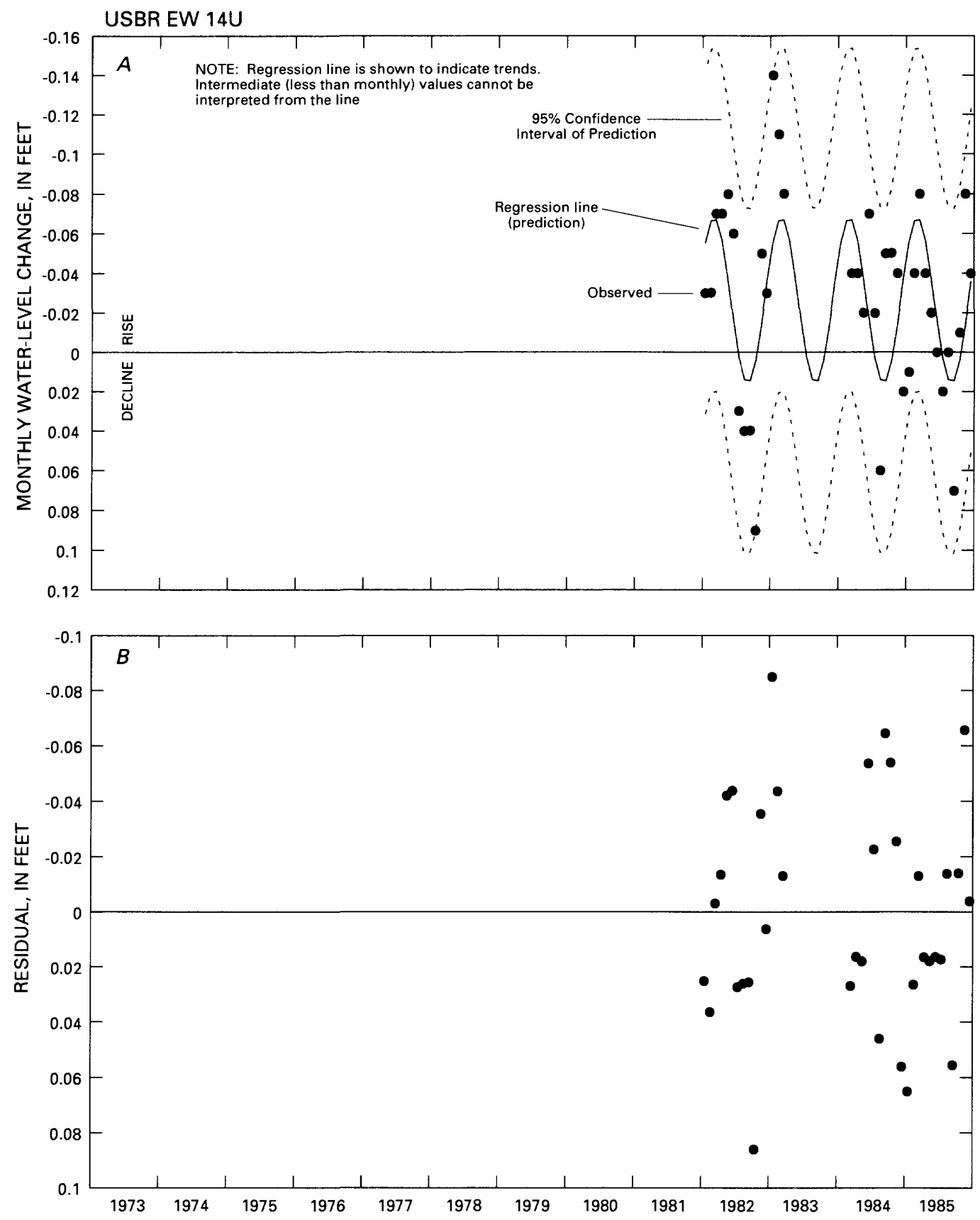

Flgure B-13. (A) Observed and predicted water-level change and confidence limits; and (B) residual errors for observation well USBR EW 14U, closed basin of San Luis Valley. 

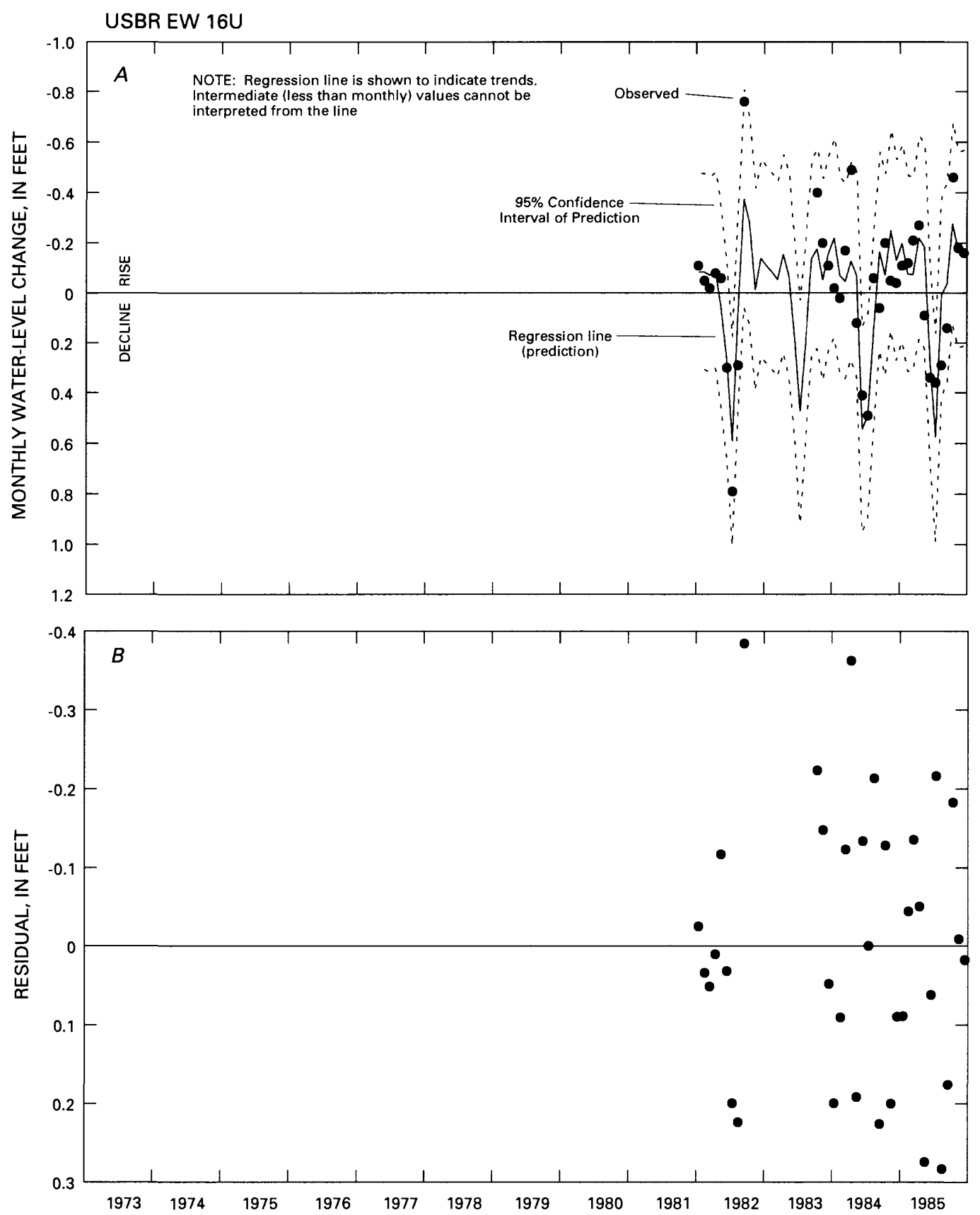

Figure B-14. (A) Observed and predicted water-level change and confidence limits; and (B) residual errors for observation well USBR EW 16U, closed basin of San Luis Valley. 

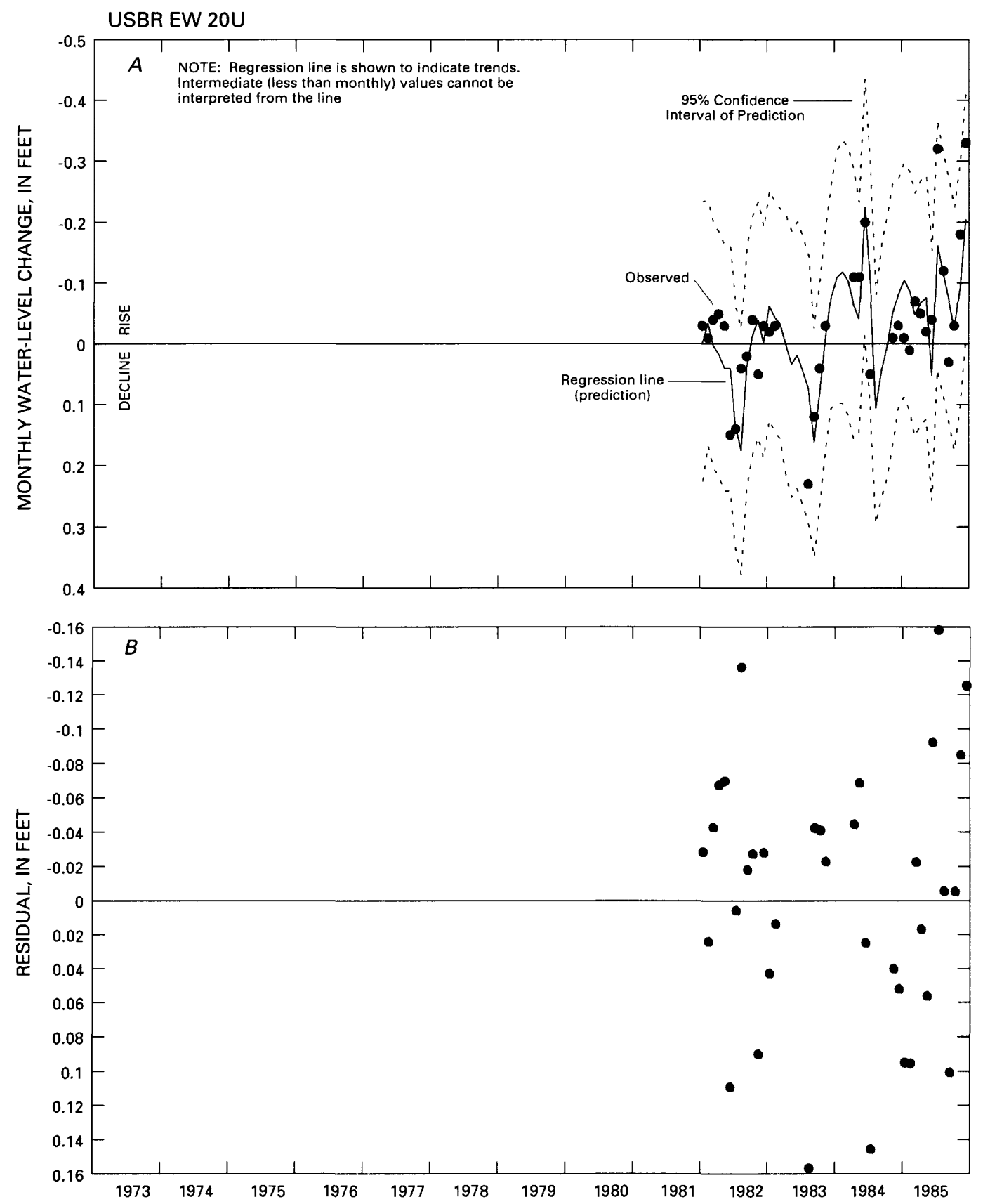

Figure B-15. (A) Observed and predicted water-level change and confidence limits; and (B) residual errors for observation well USBR EW 20U, closed basin of San Luis Valley. 

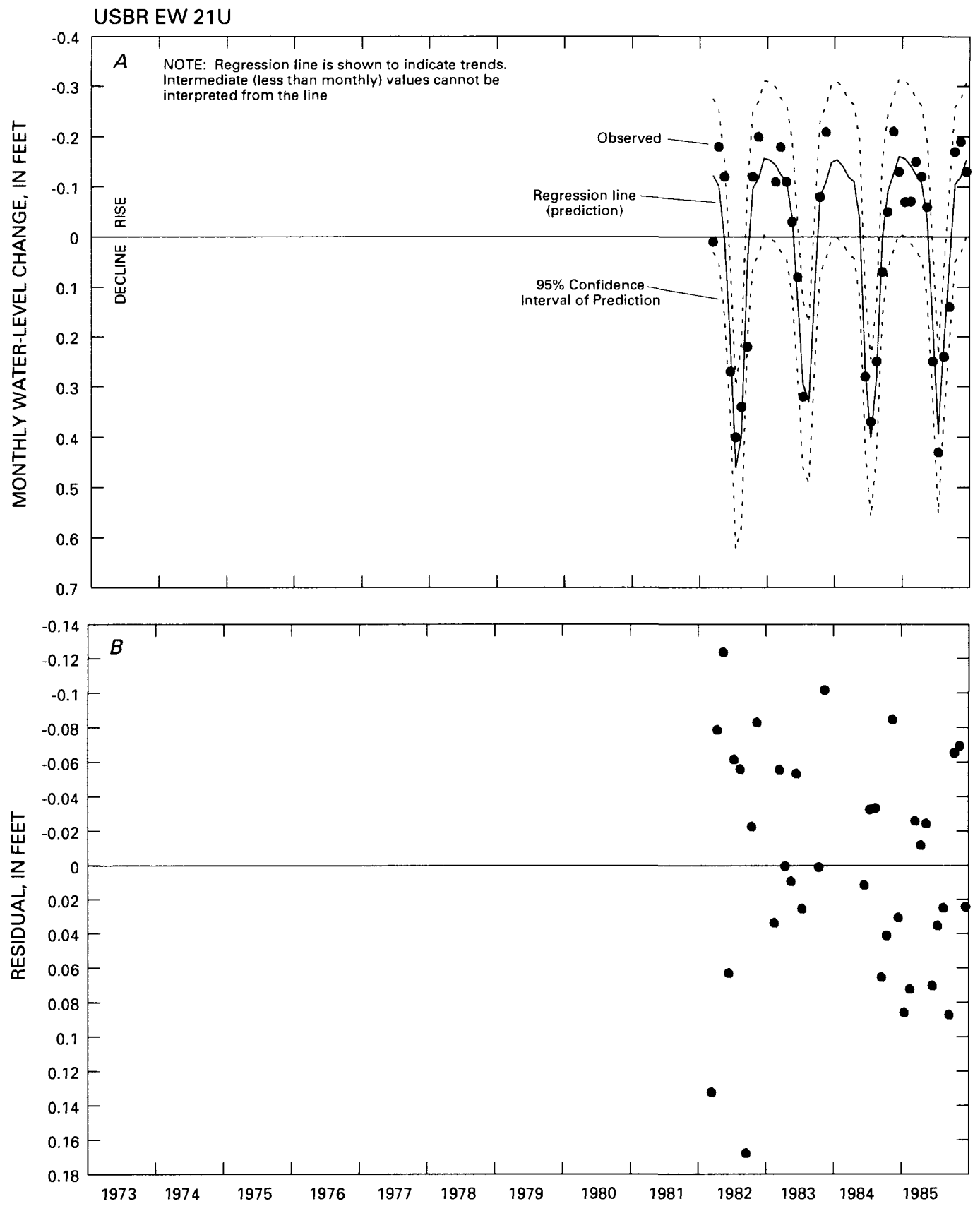

Figure B-16. (A) Observed and predicted water-level change and confidence limits; and (B) residual errors for observation well USBR EW 21U, closed basin of San Luis Valley. 

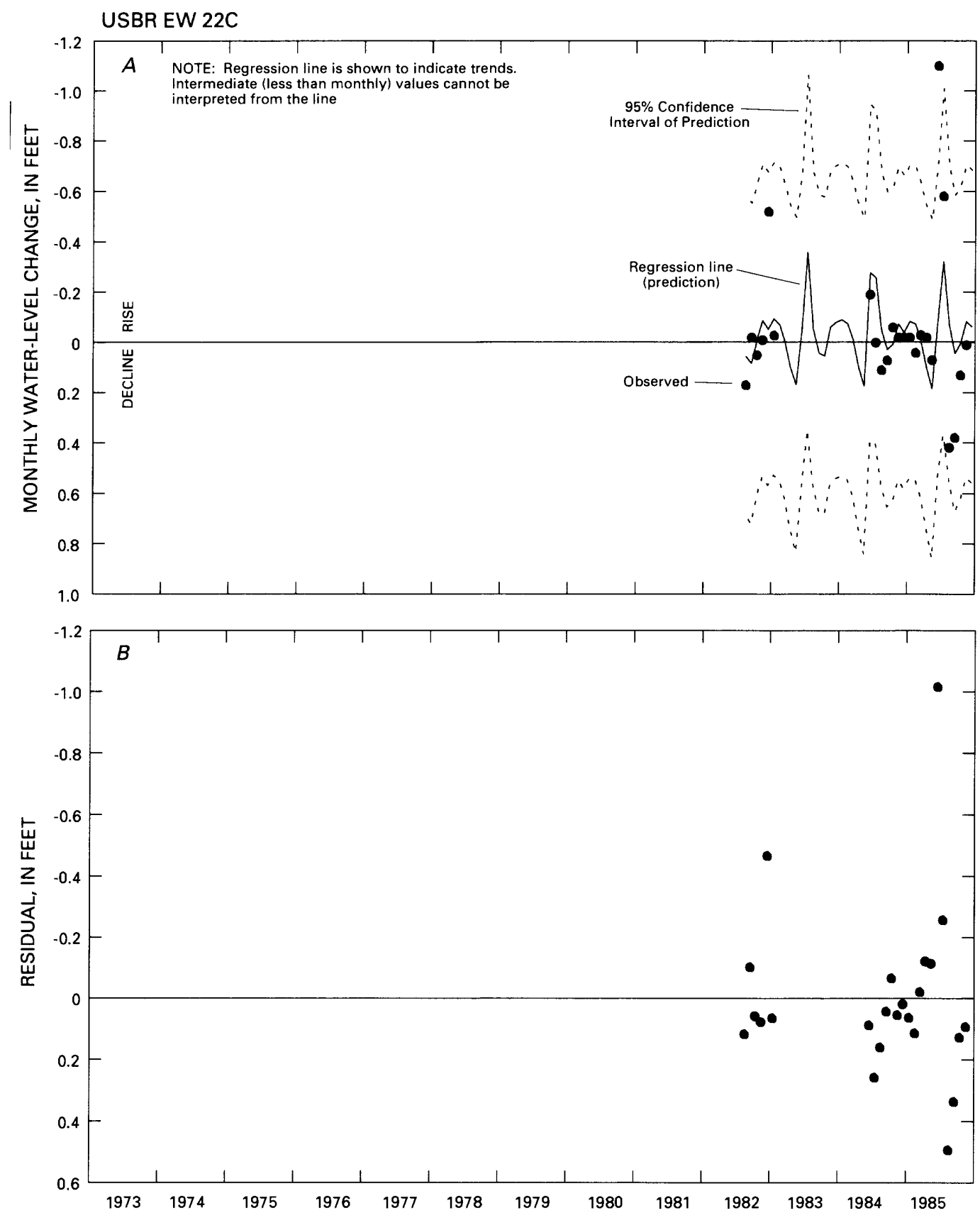

Figure B-17. (A) Observed and predicted water-level change and confidence limits; and (B) residual errors for observation well USBR EW 22C, closed basin of San Luis Valley. 

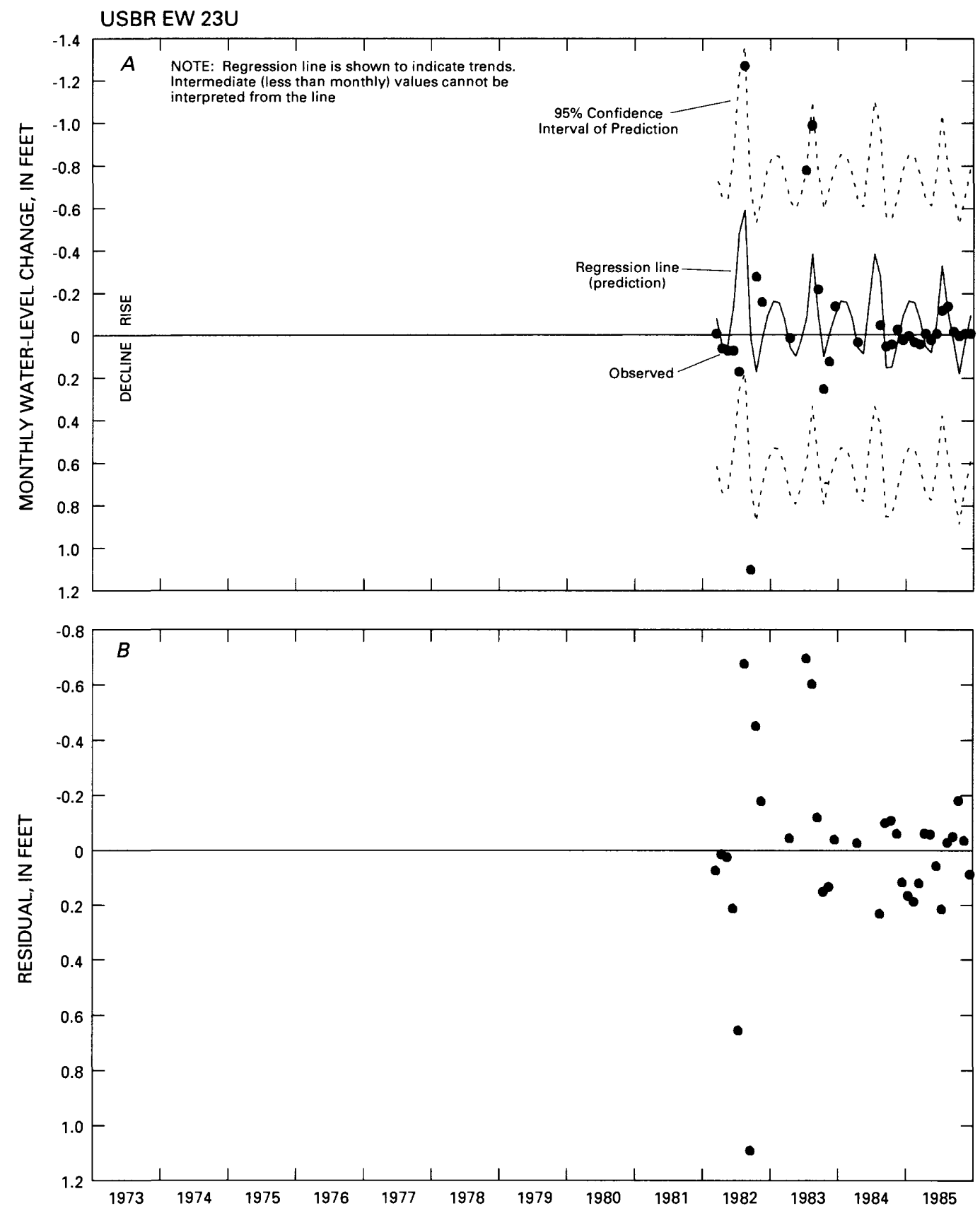

Figure B-18. (A) Observed and predicted water-level change and confidence limits; and (B) residual errors for observation well USBR EW 23U, closed basin of San Luis Valley. 

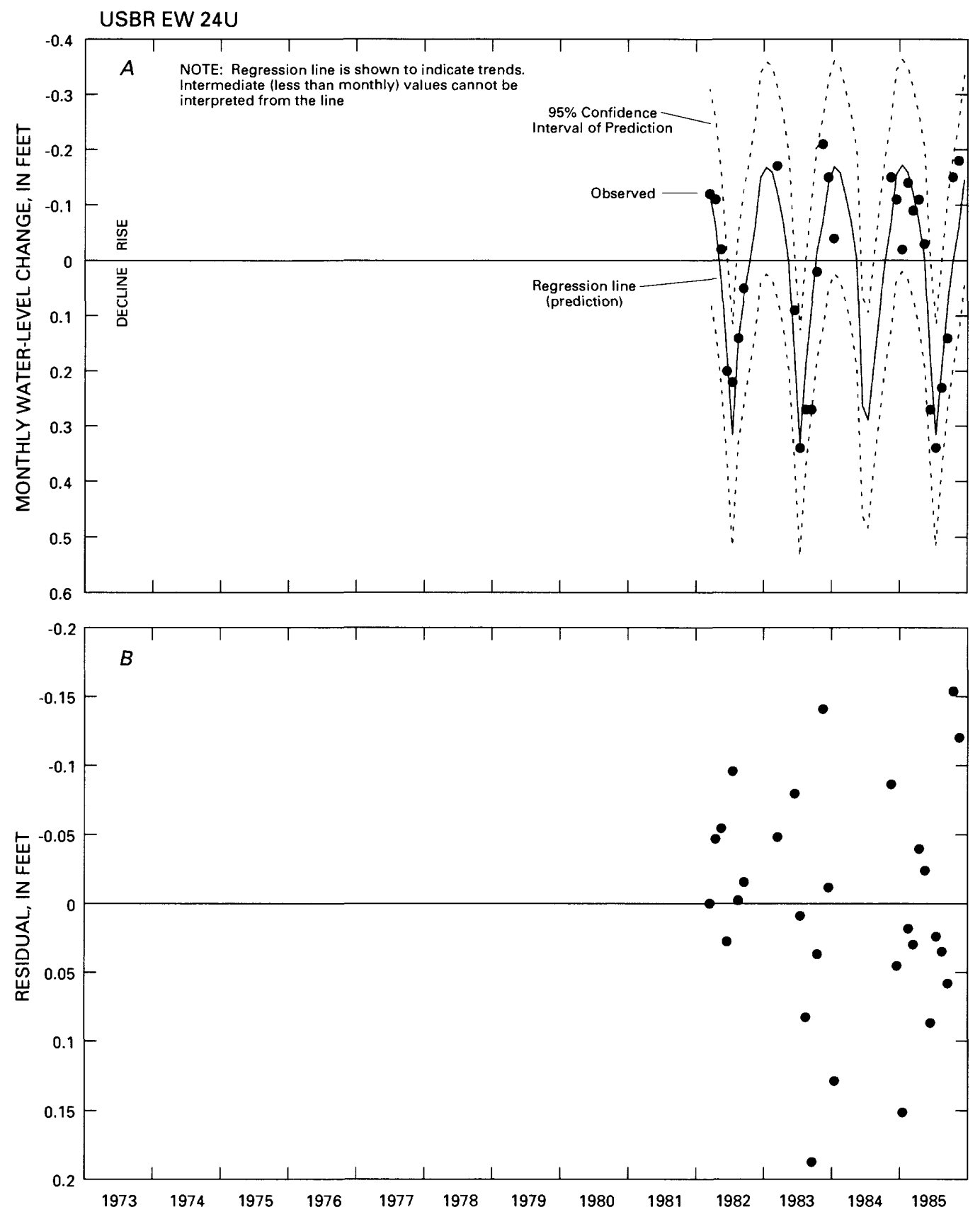

Figure B-19. (A) Observed and predicted water-level change and confidence limits; and (B) residual errors for observation well USBR EW $24 U$, closed basin of San Luis Valley. 

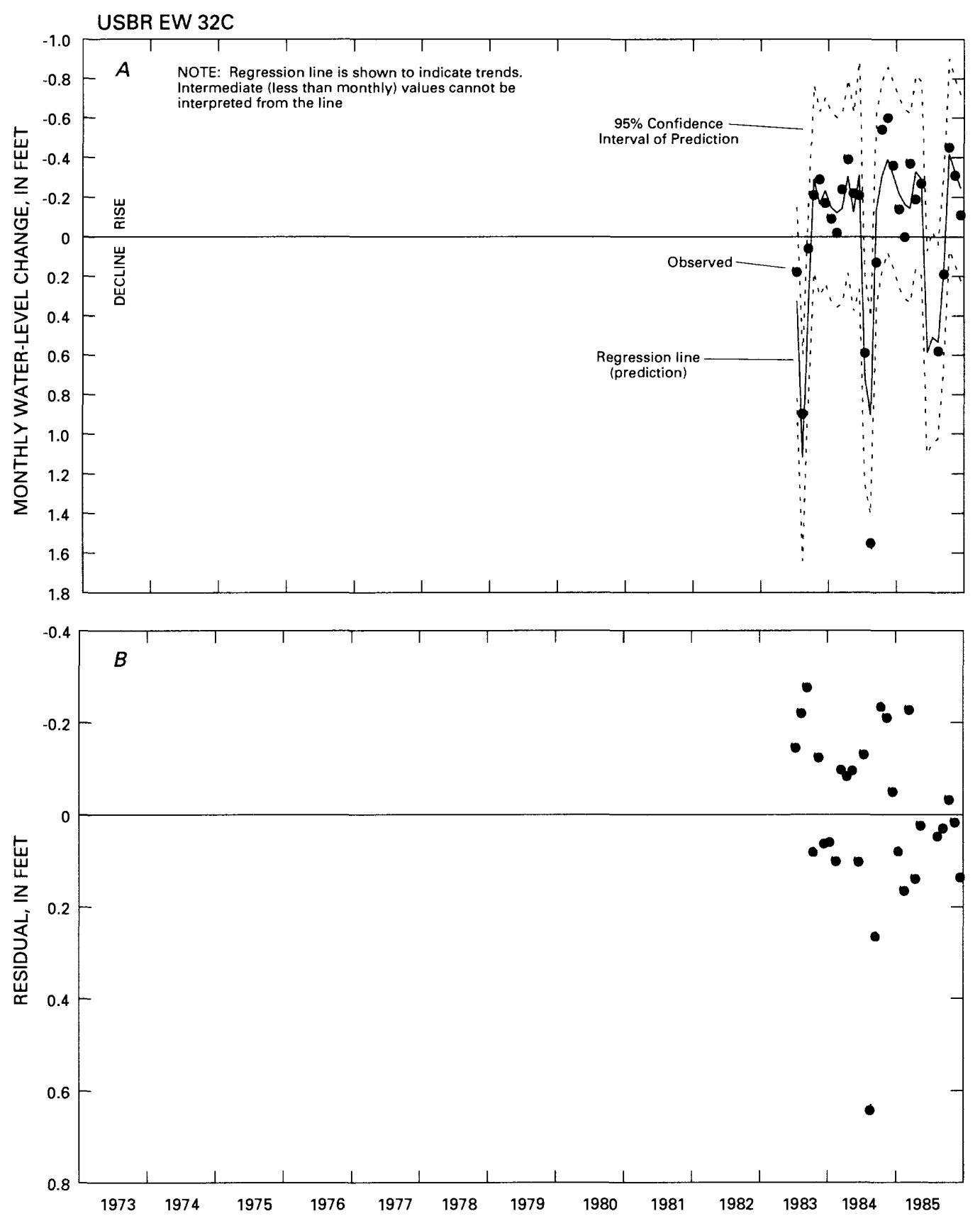

Figure B-20. (A) Observed and predicted water-level change and confidence limits; and (B) residual errors for observation well USBR EW 32C, closed basin of San Luis Valley. 

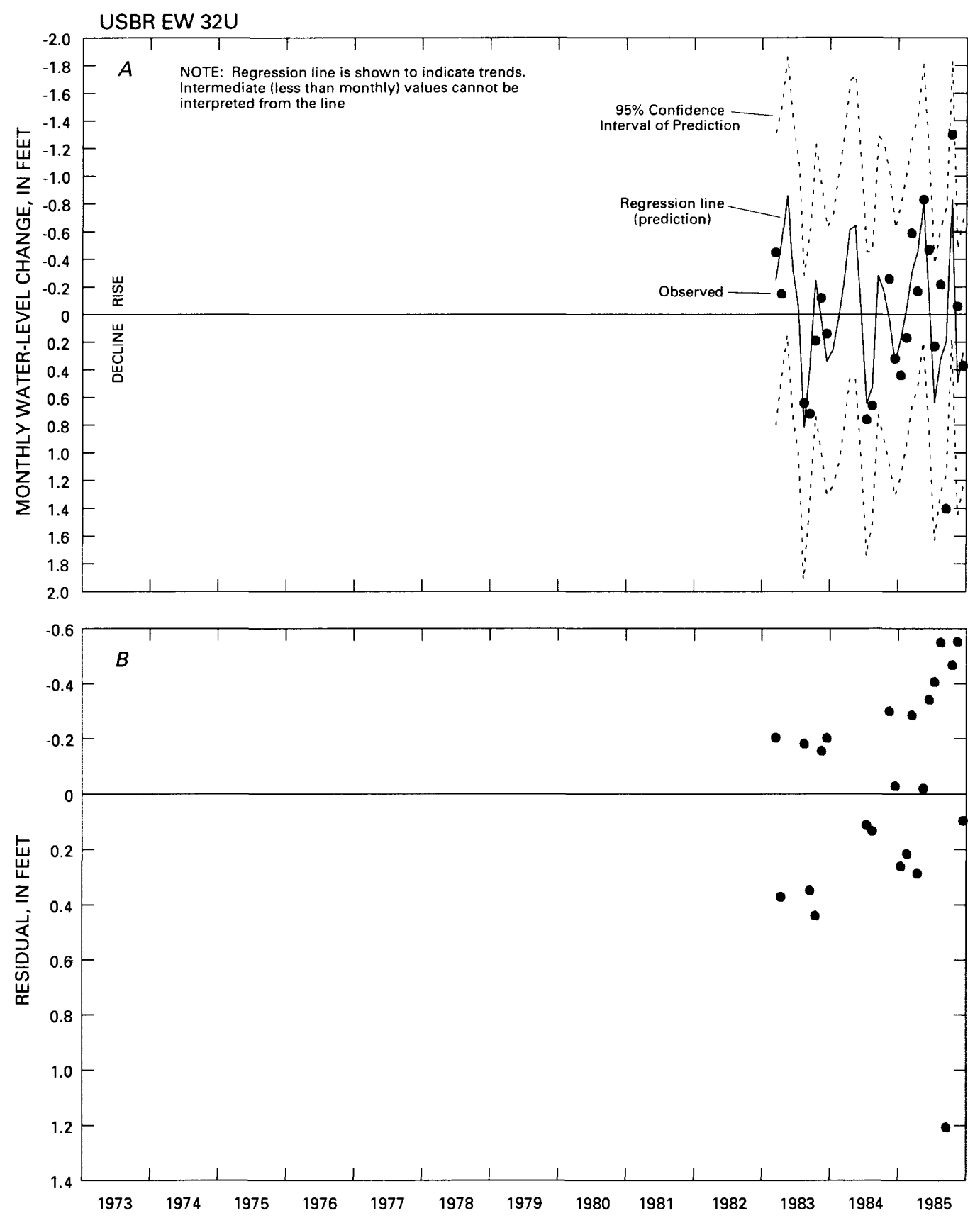

Figure B-21. (A) Observed and predicted water-level change and confidence limits; and (B) residual errors for observation well USBR EW 32U, closed basin of San Luis Valley. 

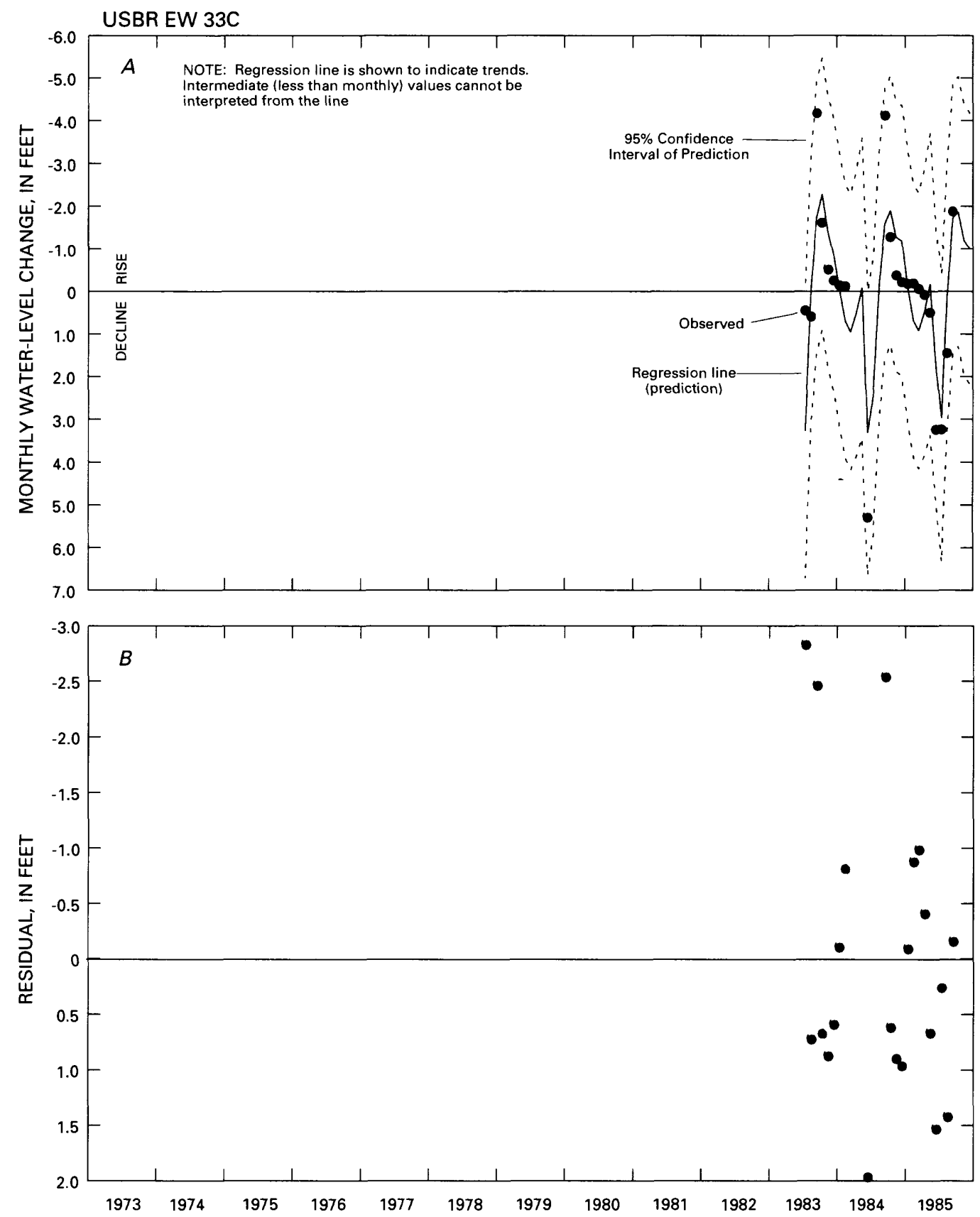

Figure B-22. (A) Observed and predicted water-level change and confidence limits; and (B) residual errors for observation well USBR EW 33C, closed basin of San Luis Valley. 

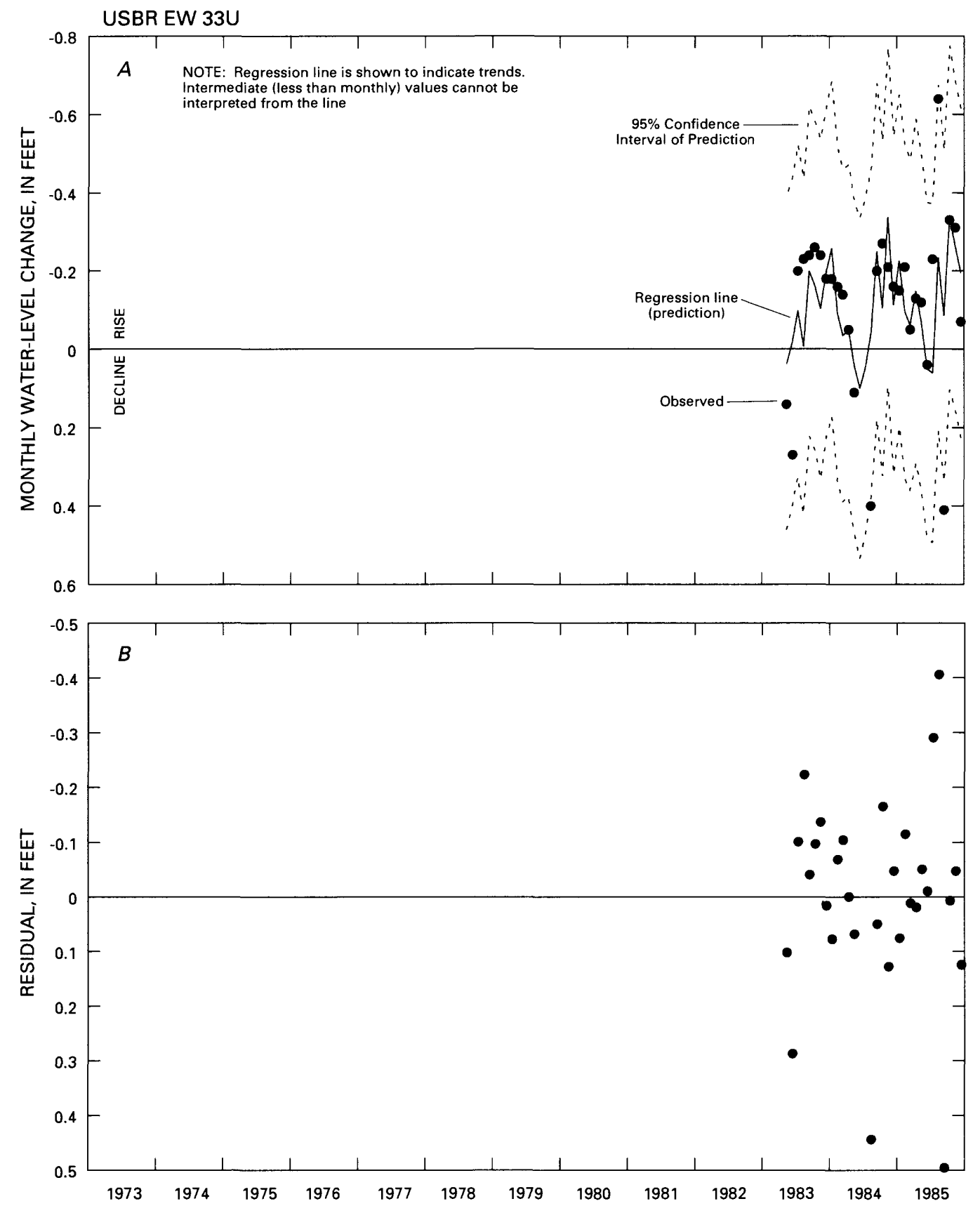

Figure B-23. (A) Observed and predicted water-level change and confidence limits; and (B) residual errors for observation well USBR EW $33 \mathrm{U}$, closed basin of San Luis Valley. 

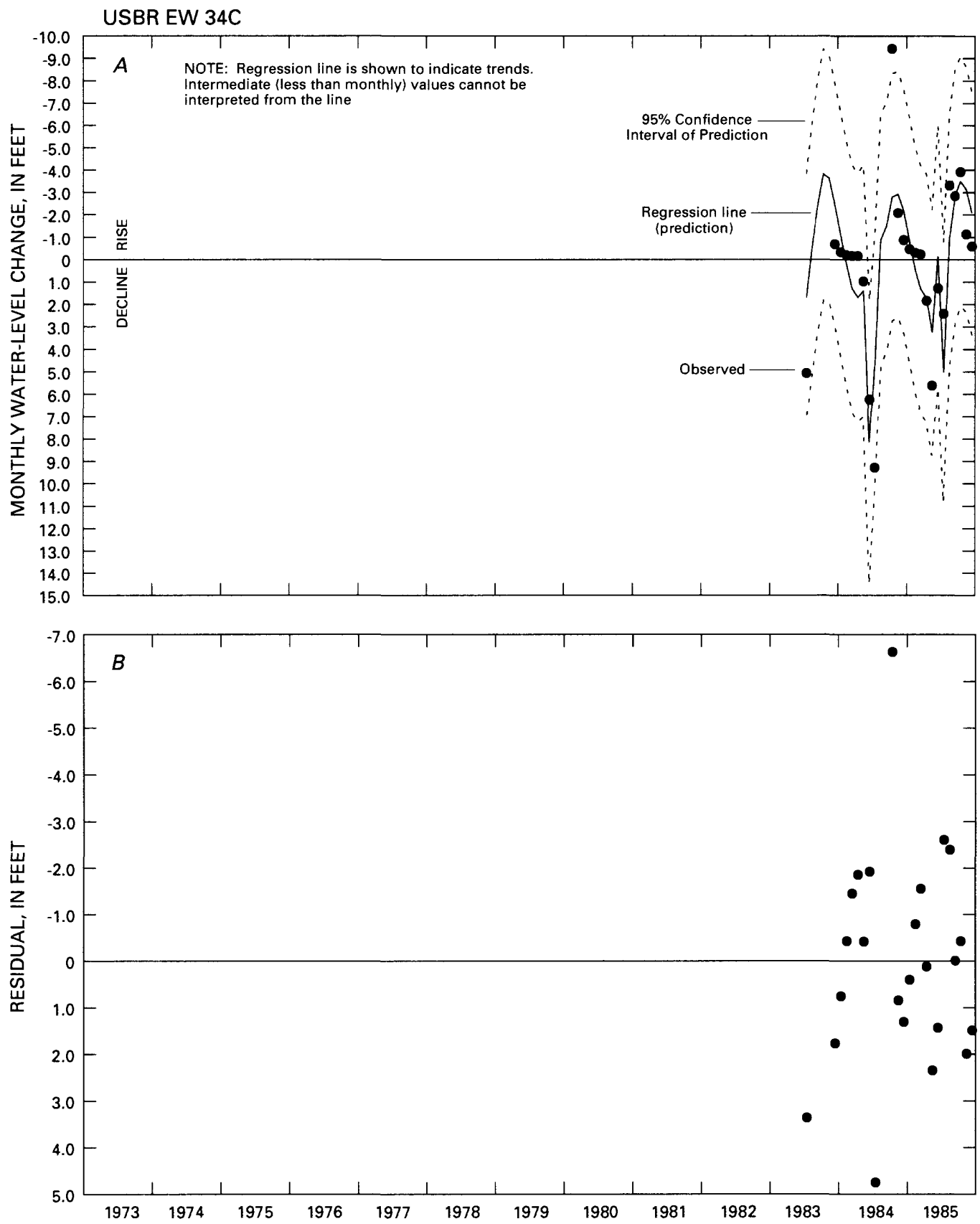

Figure B-24. (A) Observed and predicted water-level change and confidence limits; and (B) residual errors for observation well USBR EW 34C, closed basin of San Luis Valley. 

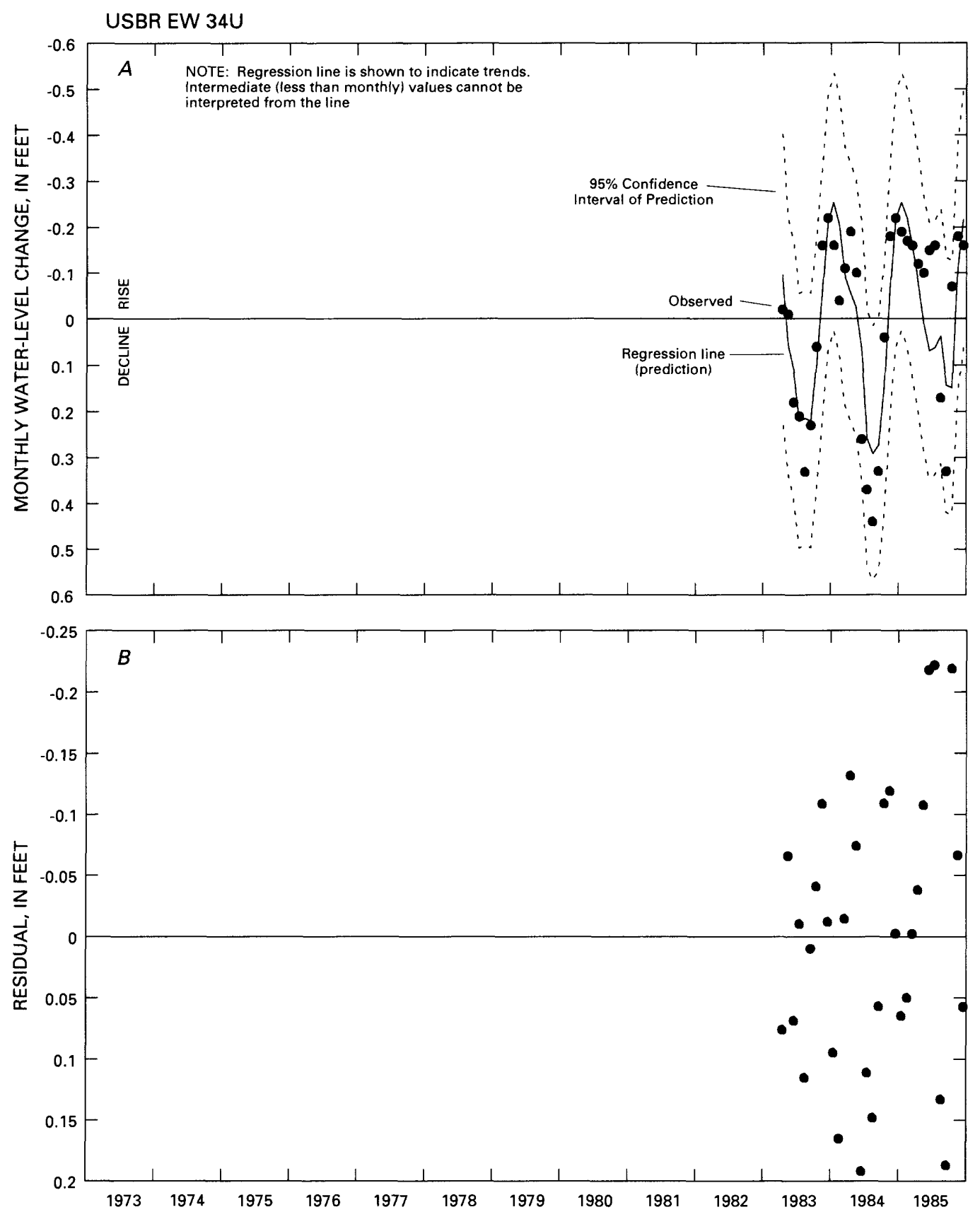

Figure B-25. (A) Observed and predicted water-level change and confidence limits; and (B) residual errors for observation well USBR EW 34U, closed basin of San Luis Valley. 

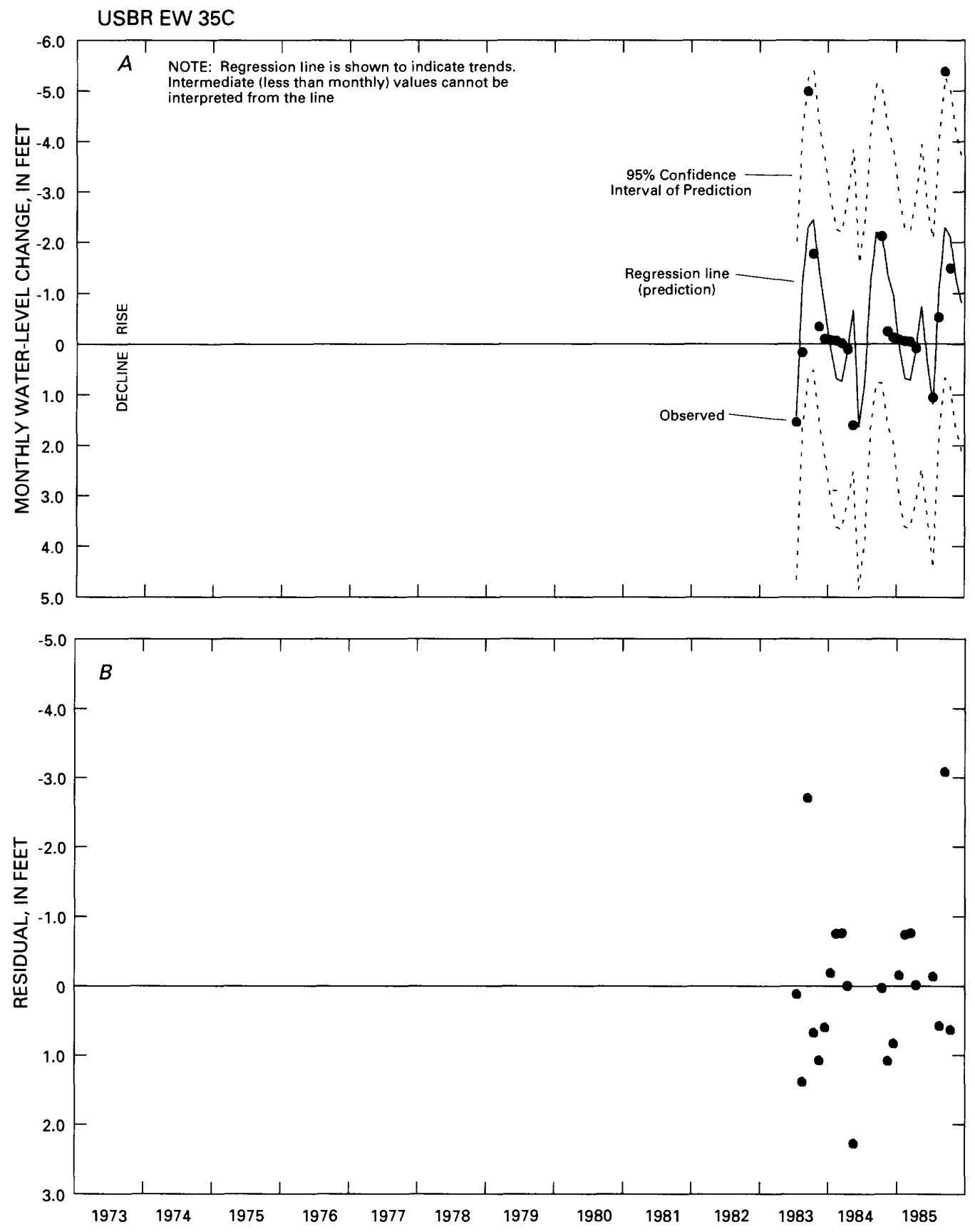

Figure B-26. (A) Observed and predicted water-level change and confidence limits; and (B) residual errors for observation well USBR EW 35C, closed basin of San Luis Valley. 

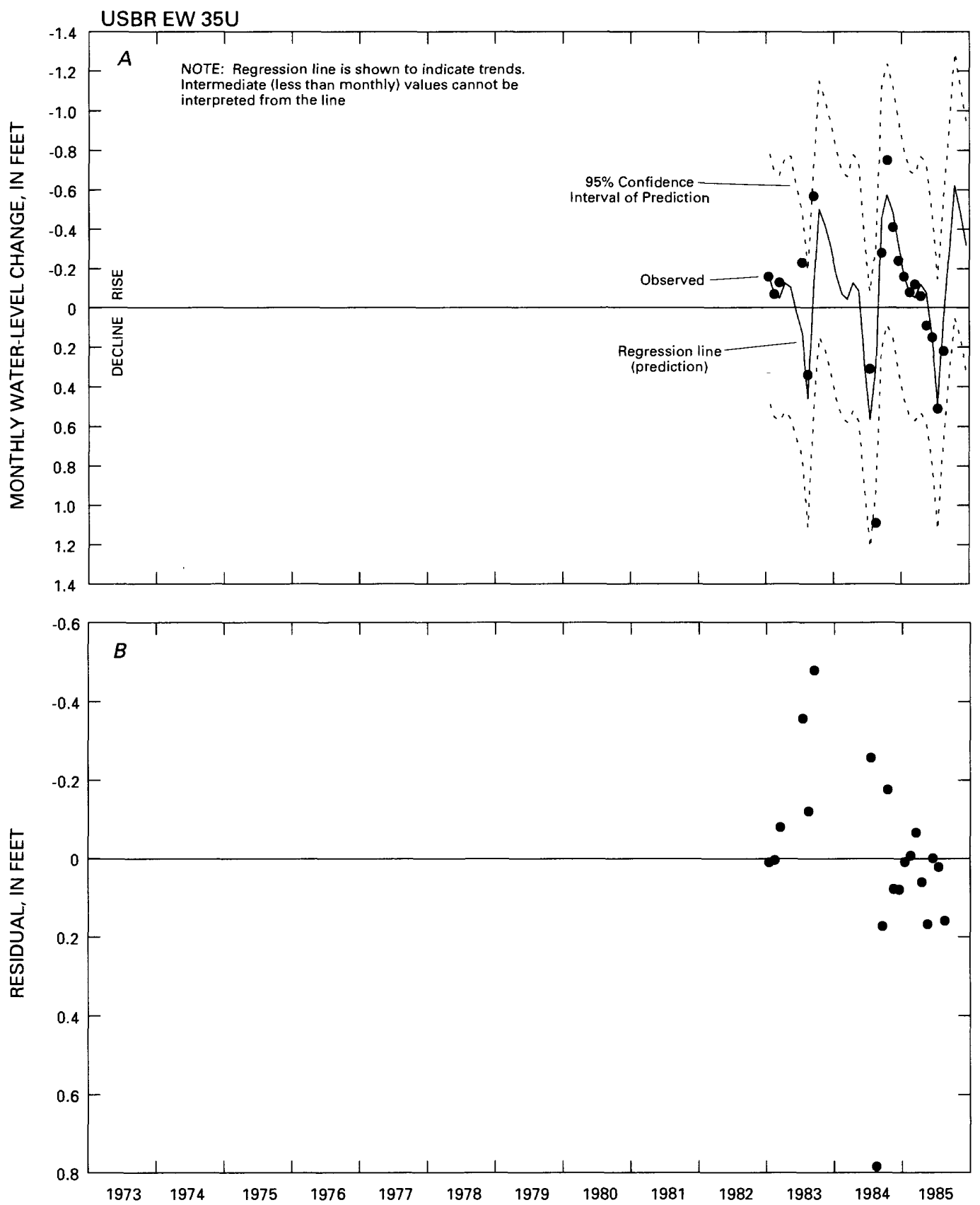

Figure B-27. (A) Observed and predicted water-level change and confidence limits; and (B) residual errors for observation well USBR EW $35 \mathrm{U}$, closed basin of San Luis Valley. 

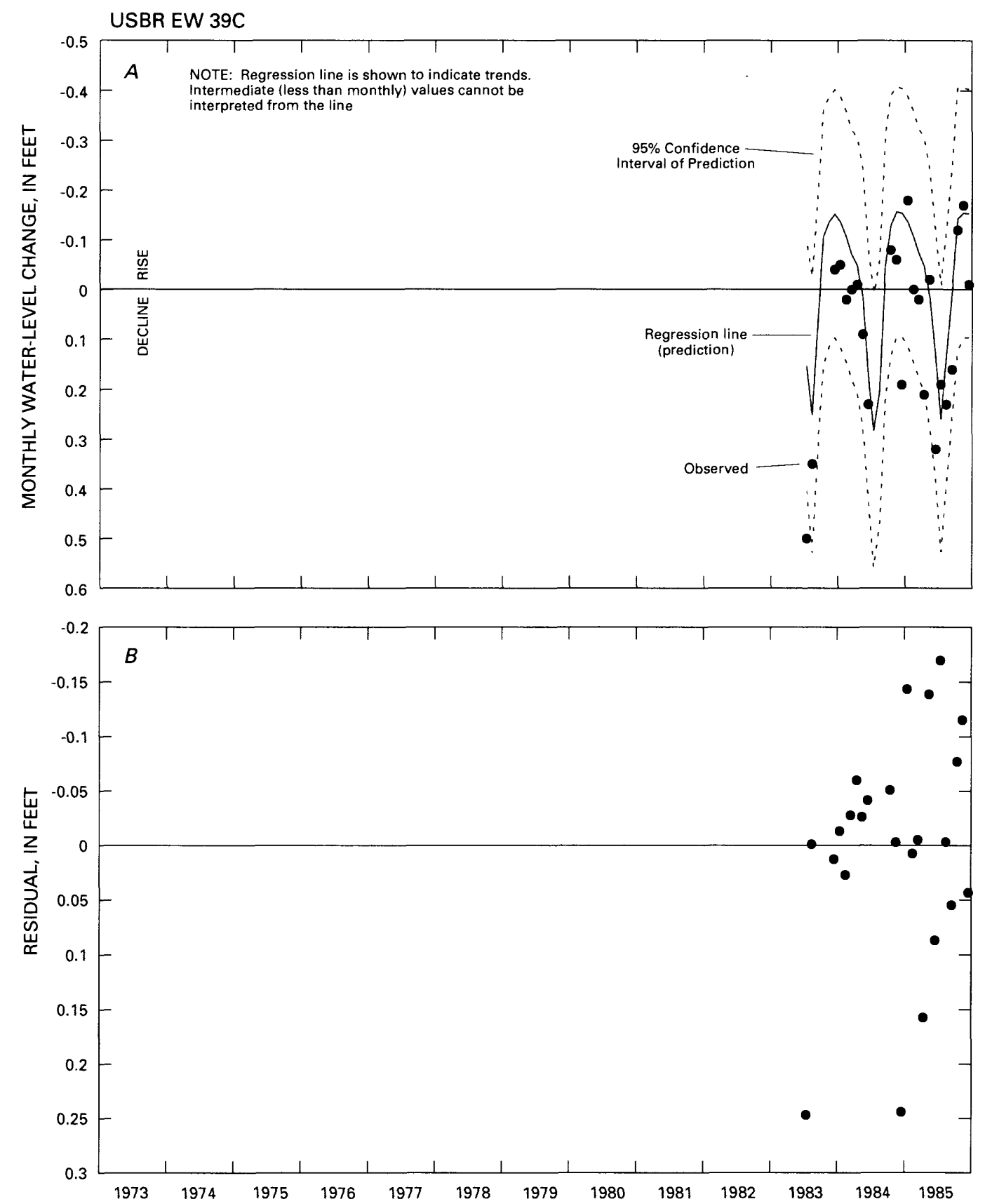

Figure B-28. (A) Observed and predicted water-level change and confidence limits; and (B) residual errors for observation well USBR EW 39C, closed basin of San Luis Valley. 

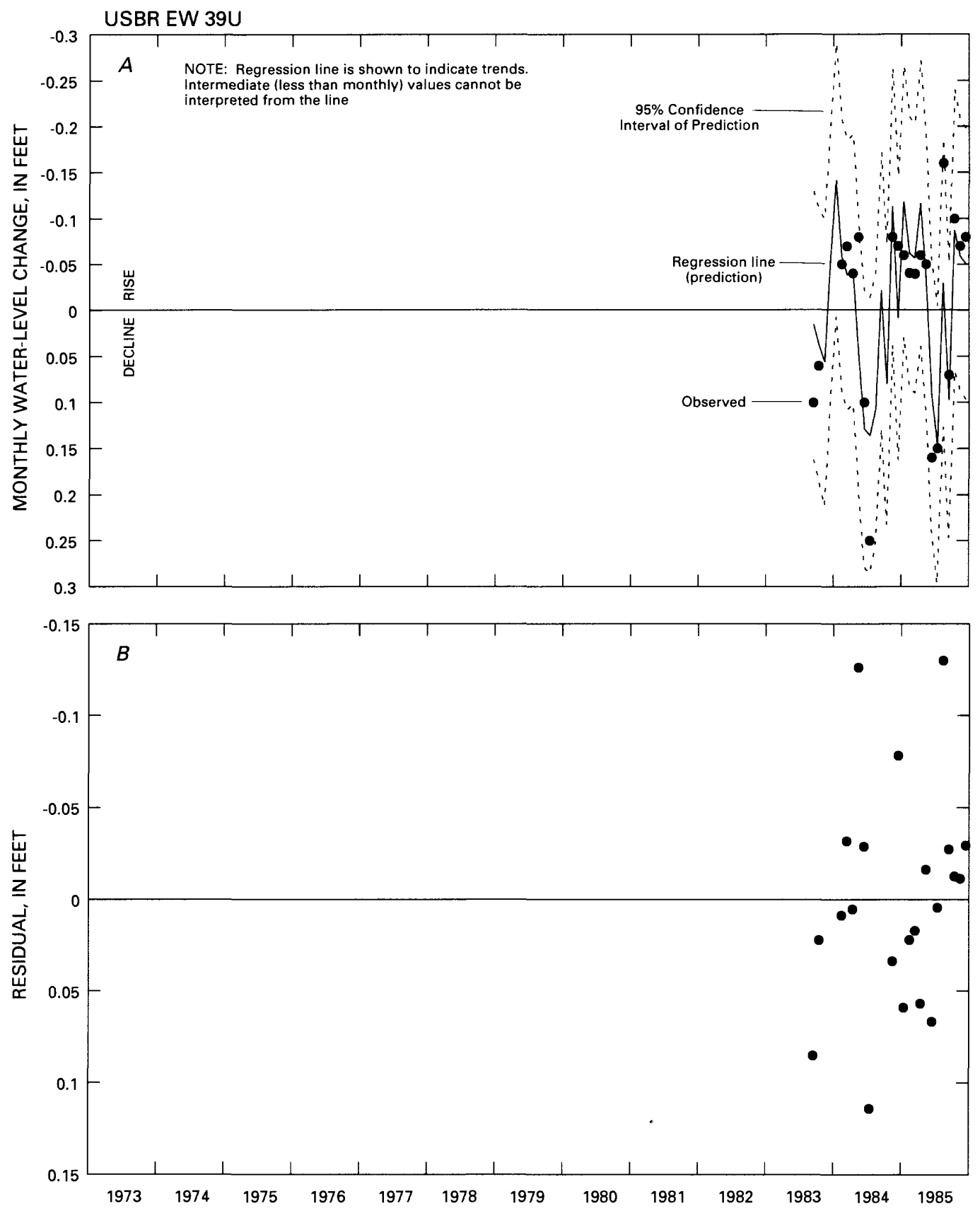

Figure B-29. (A) Observed and predicted water-level change and confidence limits; and (B) residual errors for observation well USBR EW $39 U$, closed basin of San Luis Valley. 

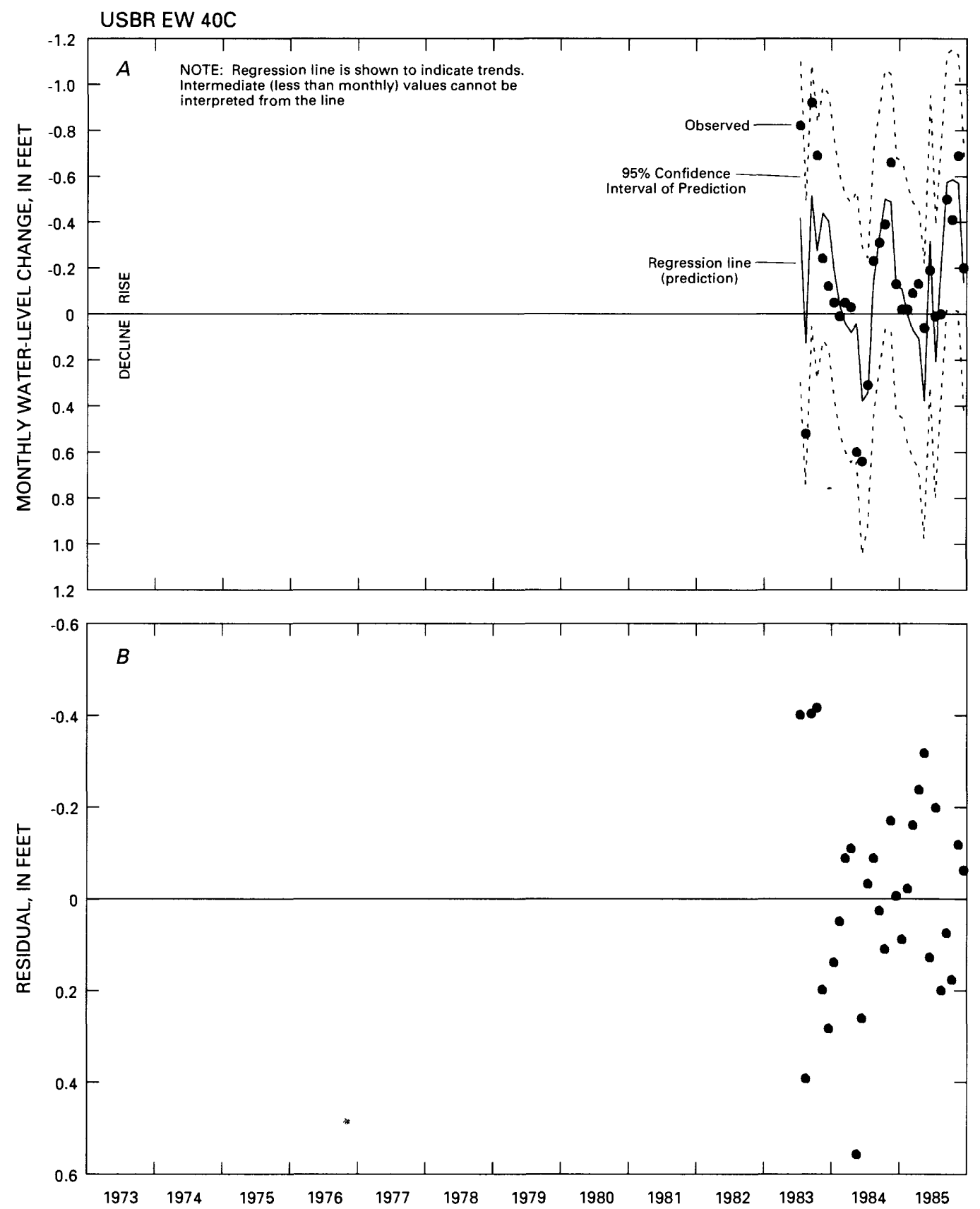

Flgure B-30. (A) Observed and predicted water-level change and confidence limits; and (B) residual errors for observation well USBR EW 40C, closed basin of San Luis Valley. 

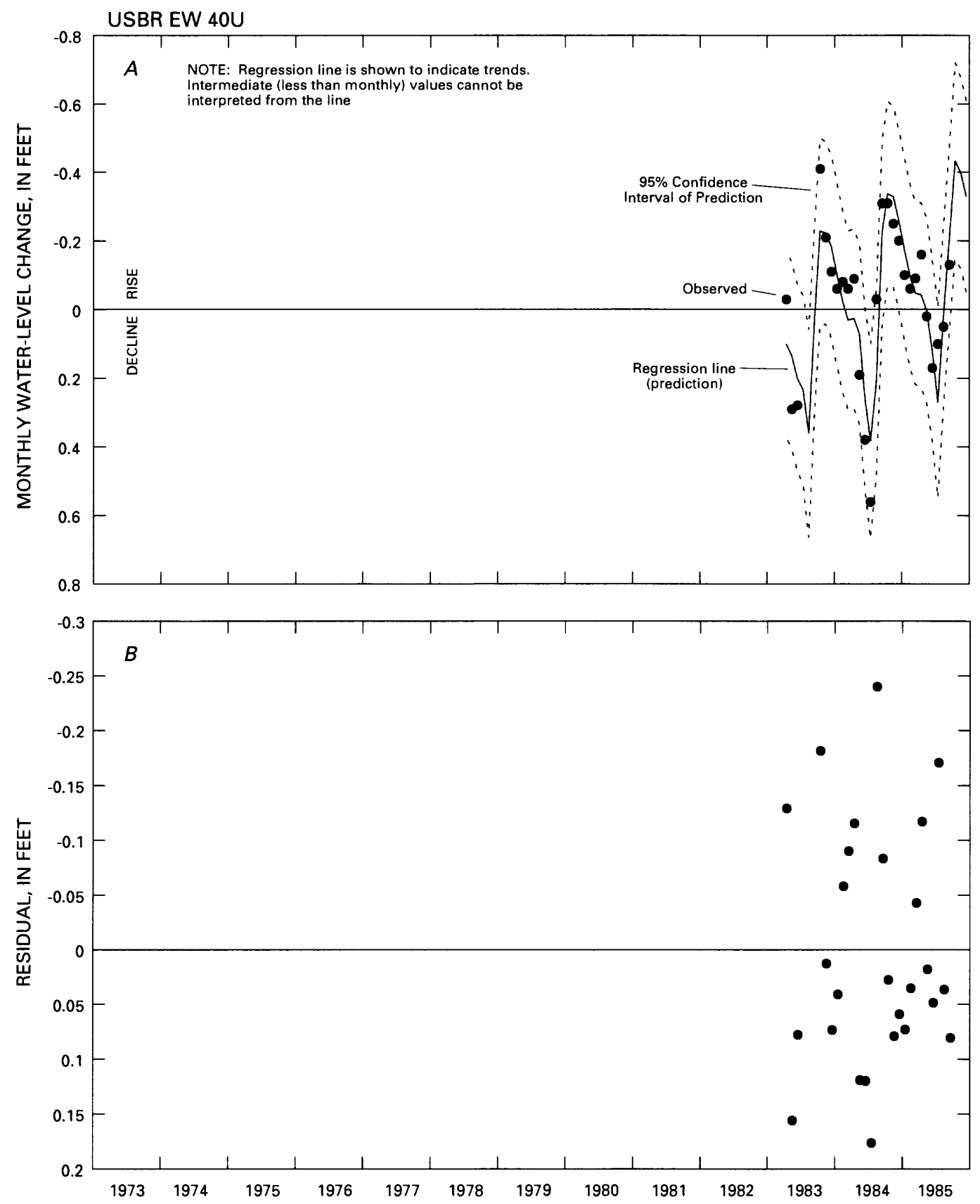

Figure B-31. (A) Observed and predicted water-level change and confidence limits; and (B) residual errors for observation well USBR EW 40U, closed basin of San Luis Valley. 

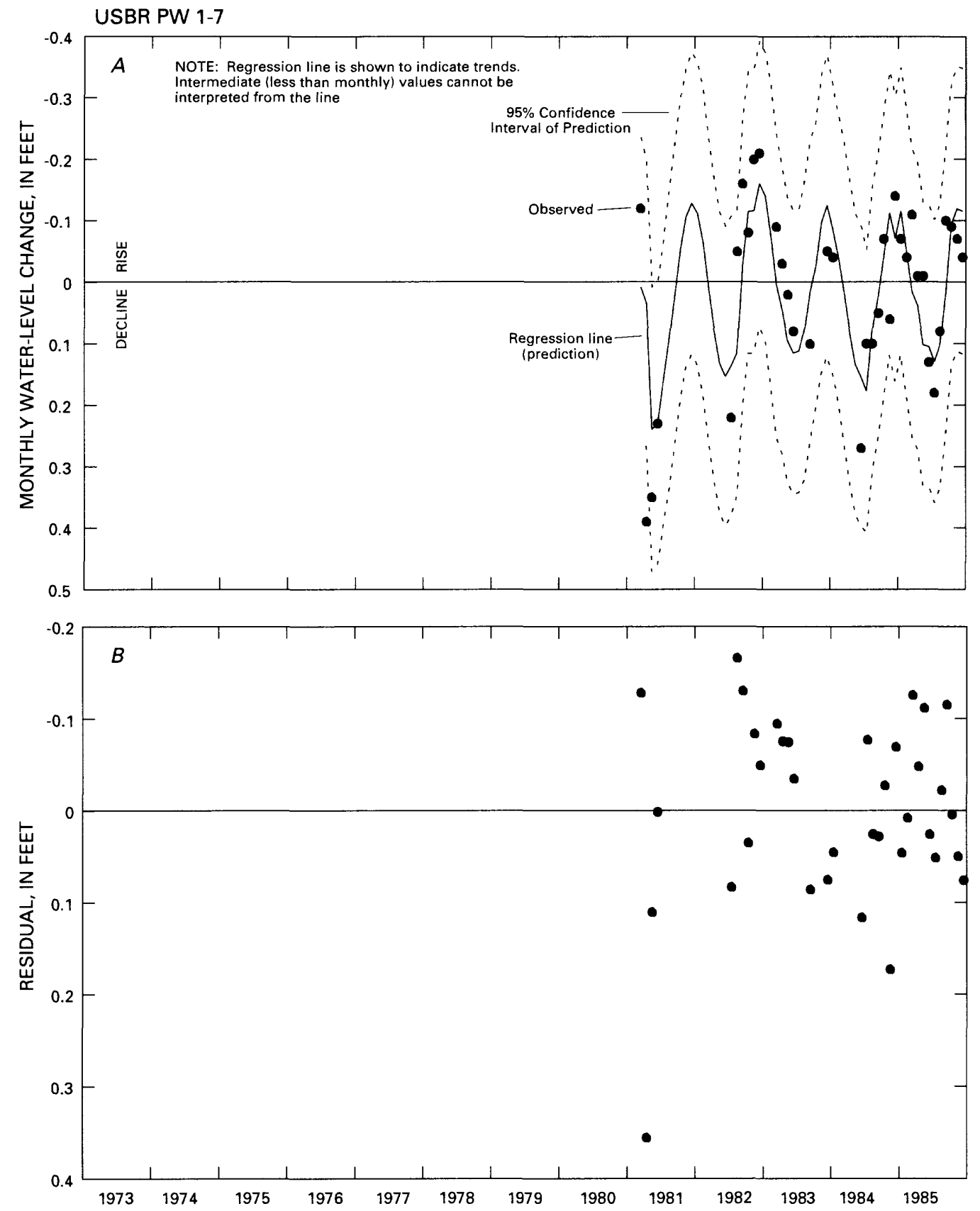

Flgure B-32. (A) Observed and predicted water-level change and confidence limits; and (B) residual errors for observation well USBR PW $1-7$, closed basin of San Luis Valley. 

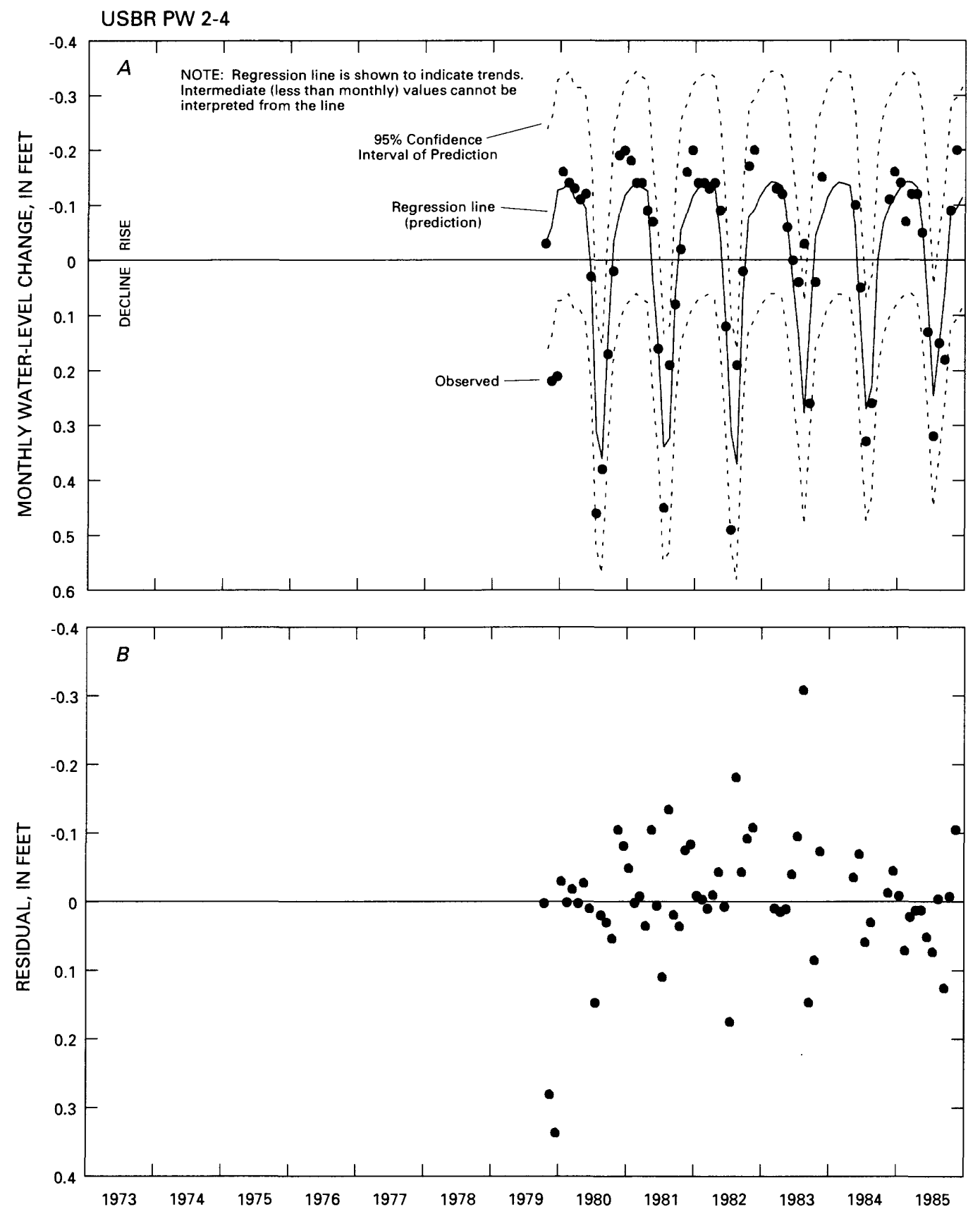

Figure B-33. (A) Observed and predicted water-level change and confidence limits; and (B) residual errors for observation well USBR PW 2-4, closed basin of San Luis Valley. 

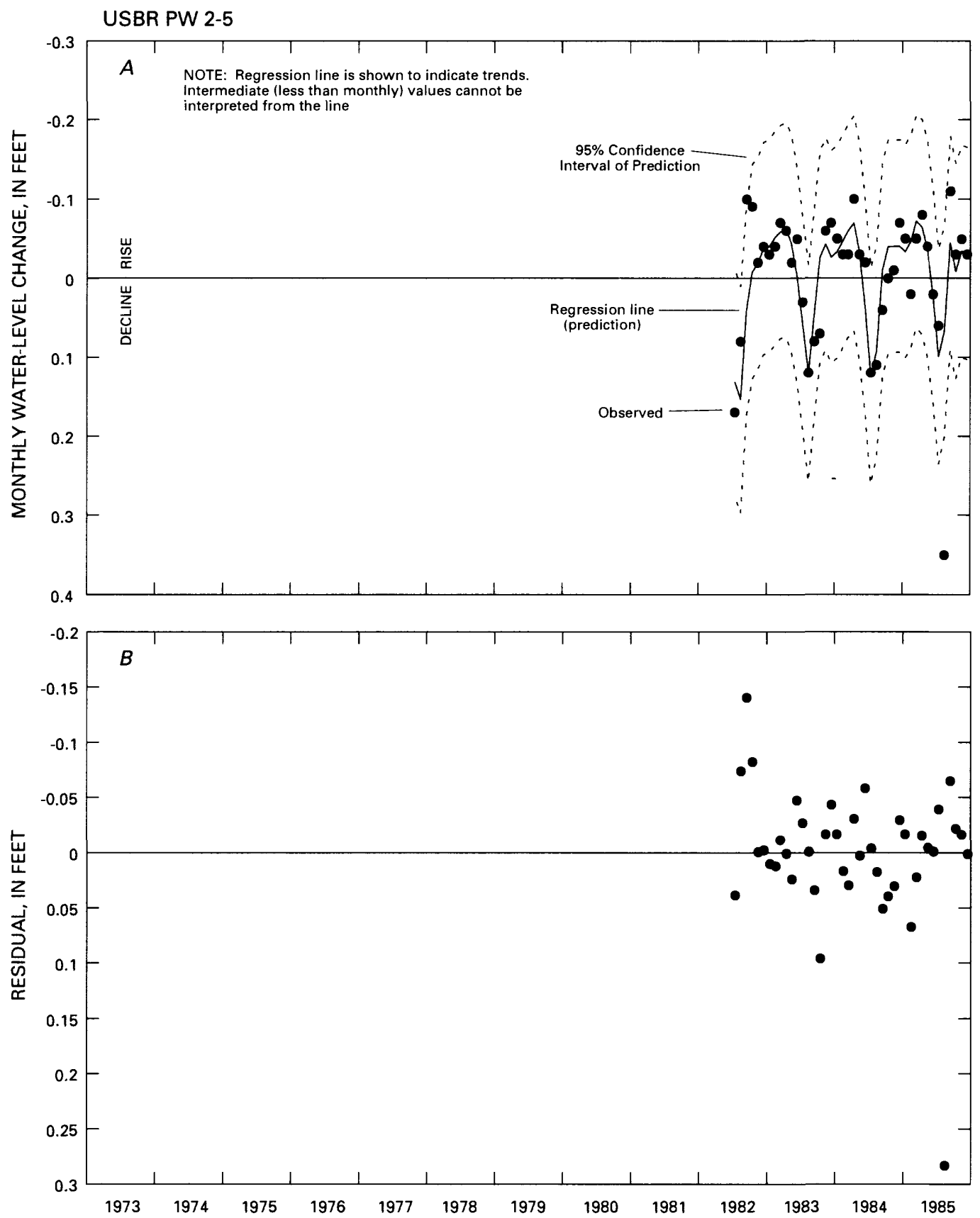

Figure B-34. (A) Observed and predicted water-level change and confidence limits; and (B) residual errors for observation well USBR PW 2-5, closed basin of San Luis Valley. 

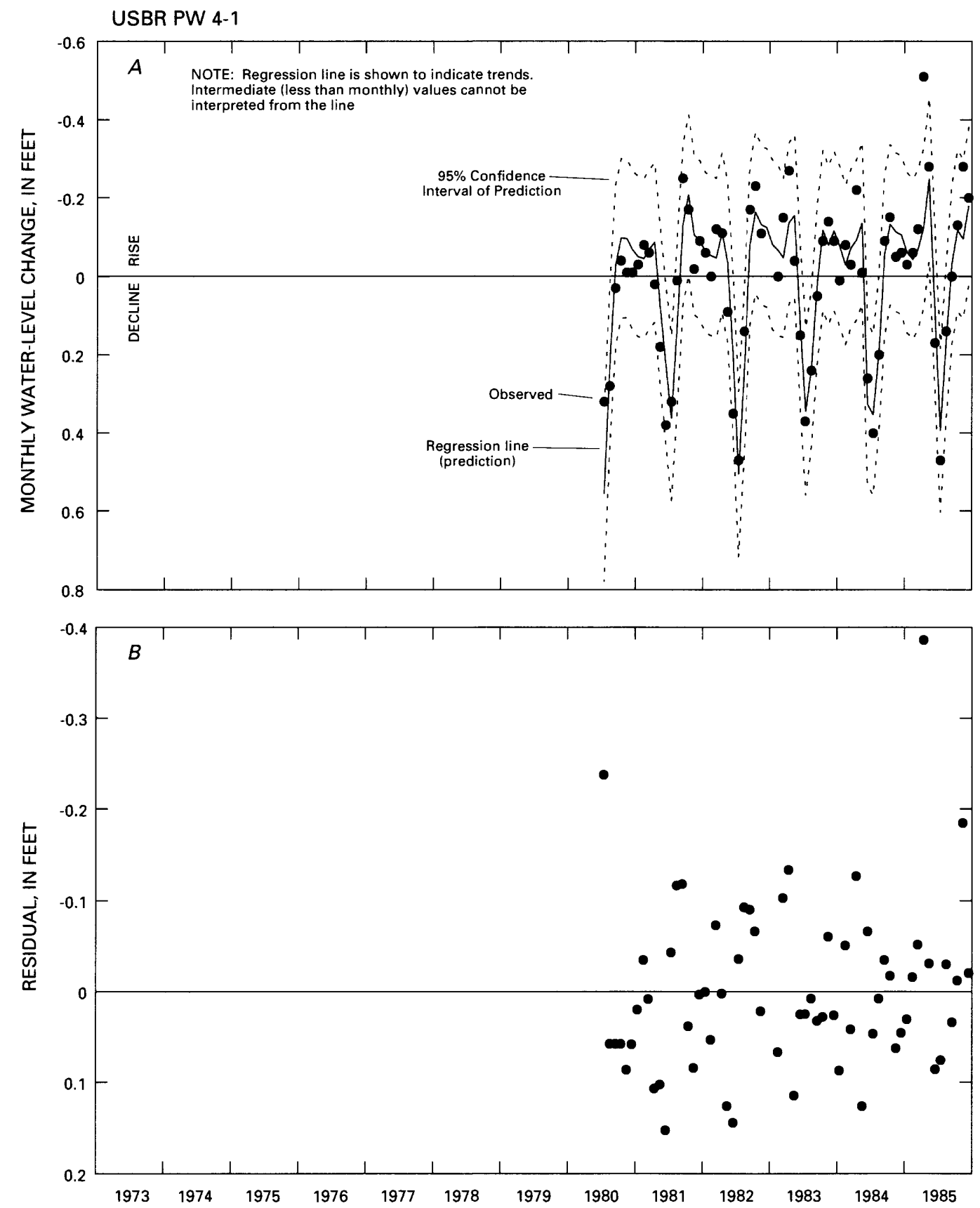

Figure B-35. (A) Observed and predicted water-level change and confidence limits; and (B) residual errors for observation well USBR PW 4-1, closed basin of San Luis Valley. 

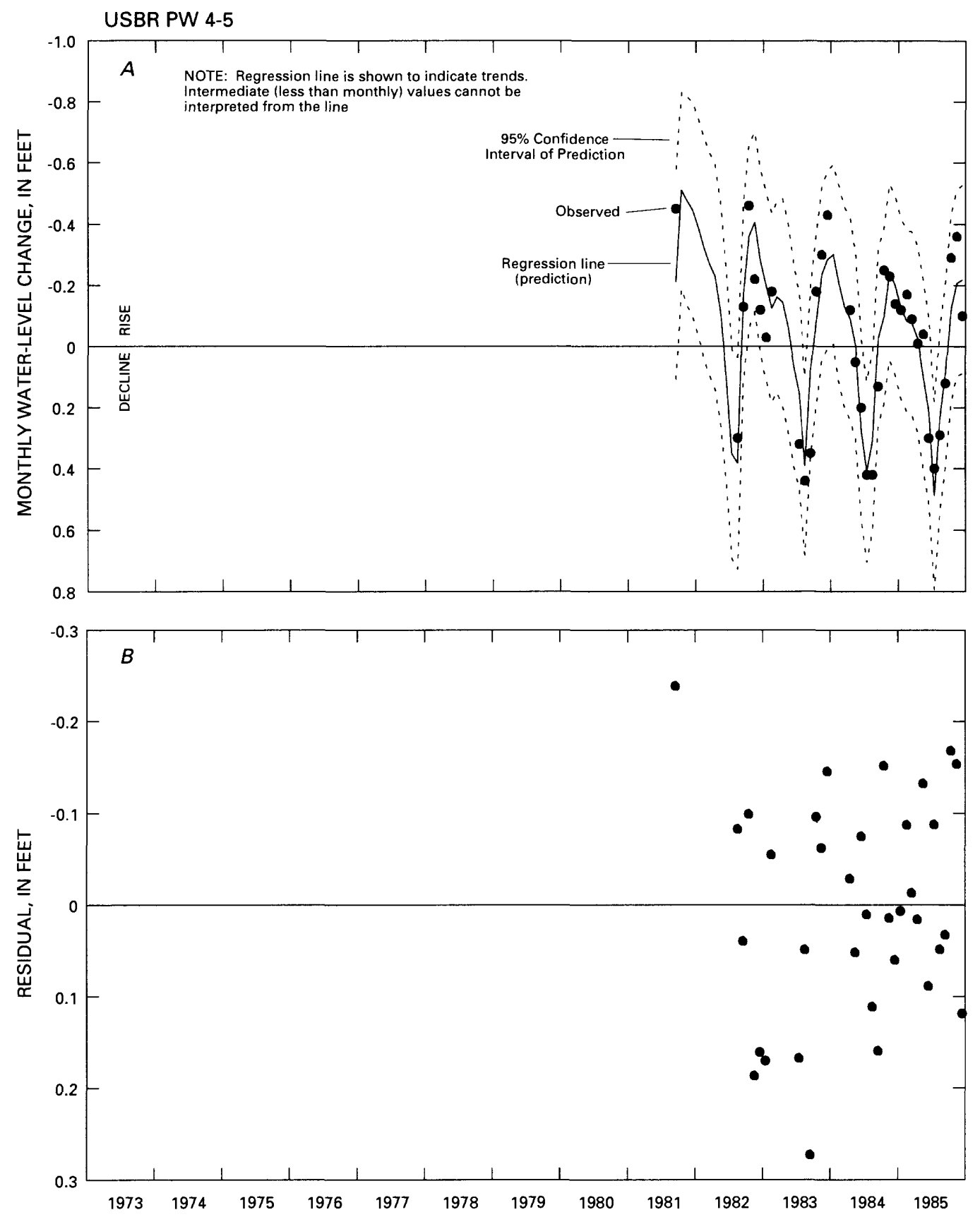

Figure B-36. (A) Observed and predicted water-level change and confidence limits; and (B) residual errors for observation well USBR PW 4-5, closed basin of San Luis Valley. 

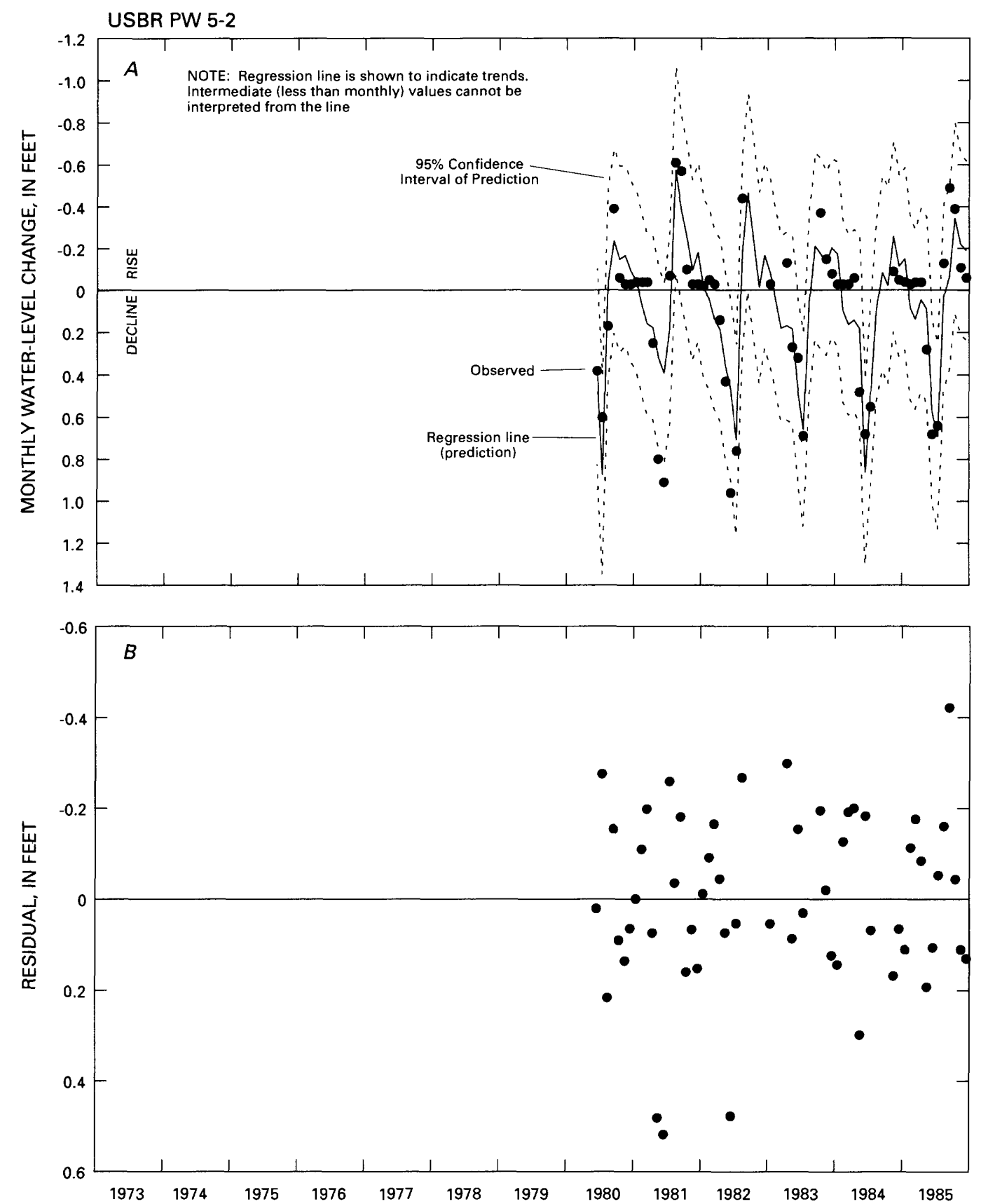

Figure B-37. (A) Observed and predicted water-level change and confidence limits; and (B) residual errors for observation well USBR PW 5-2, closed basin of San Luis Valley. 
Appendix C-V Matrices for Regression Models of Water-Level Change in the Closed Basin Division Study Area 

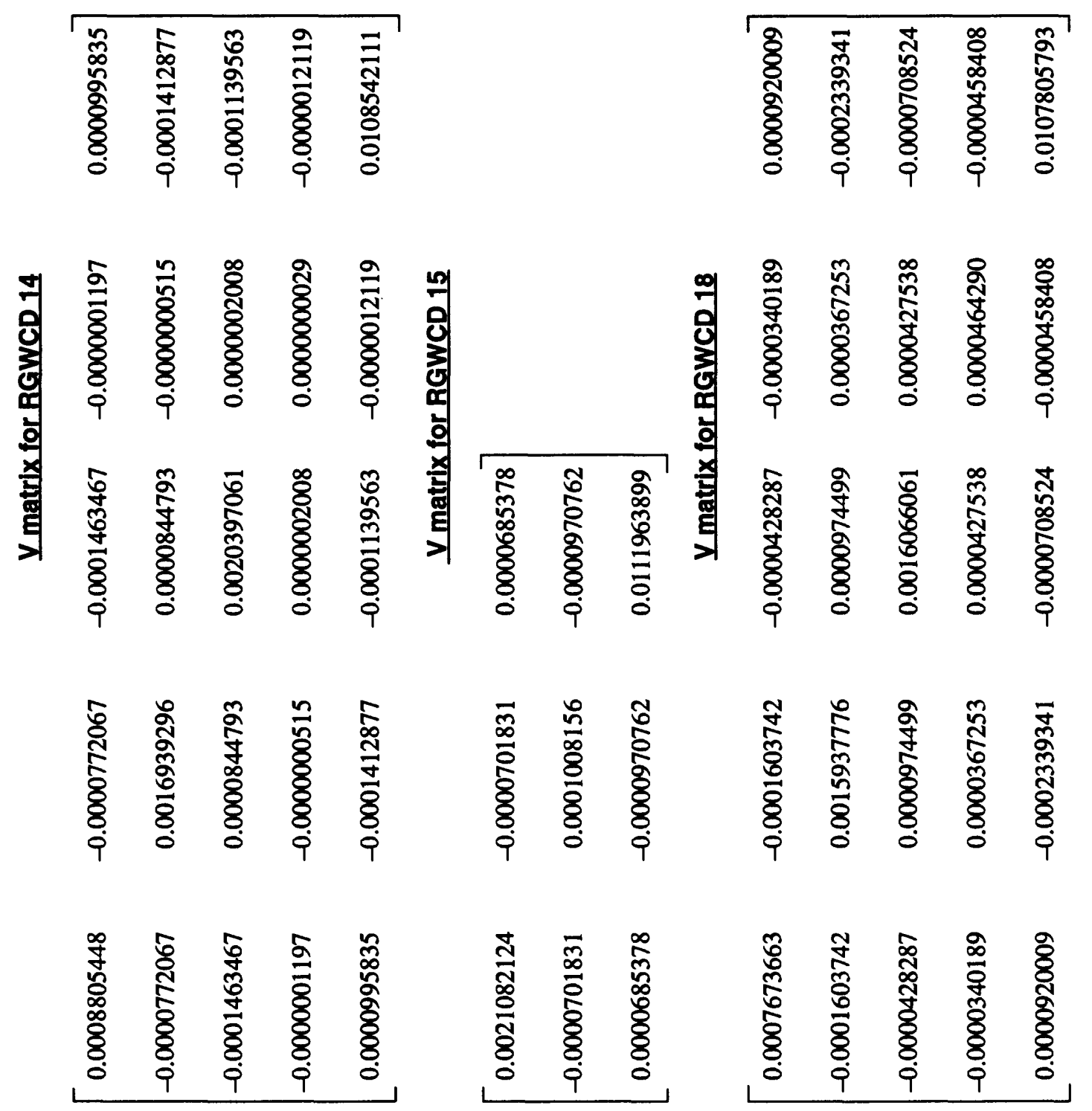

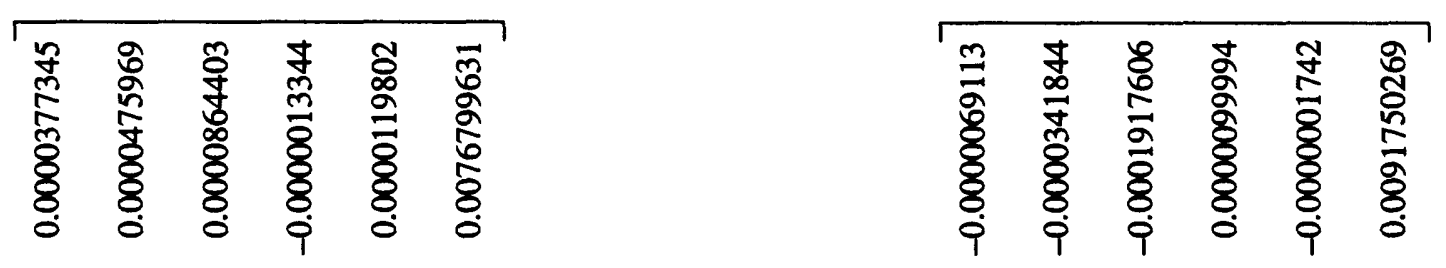

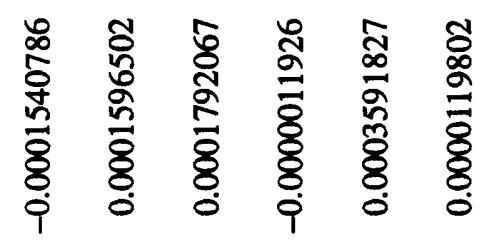
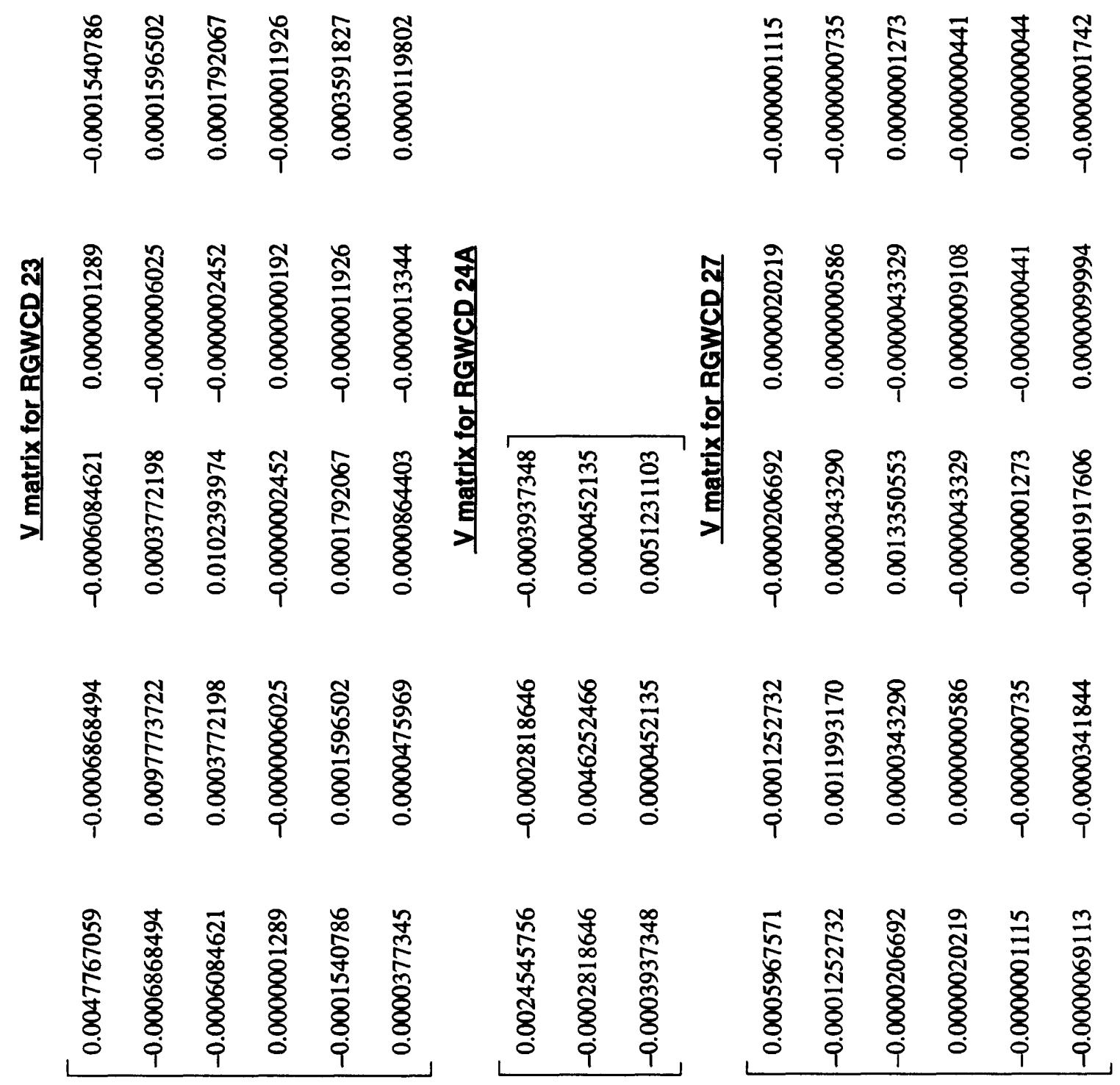

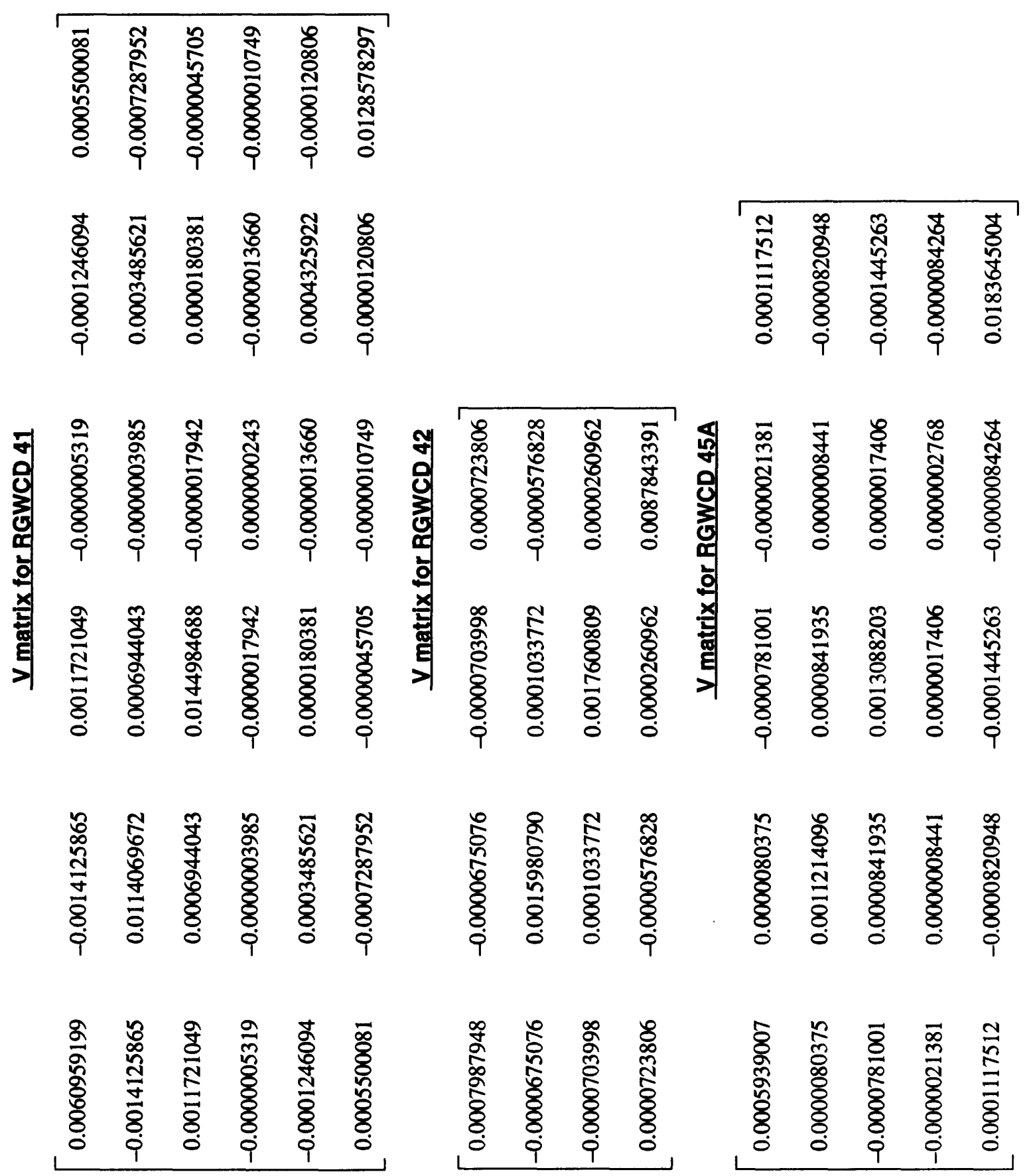

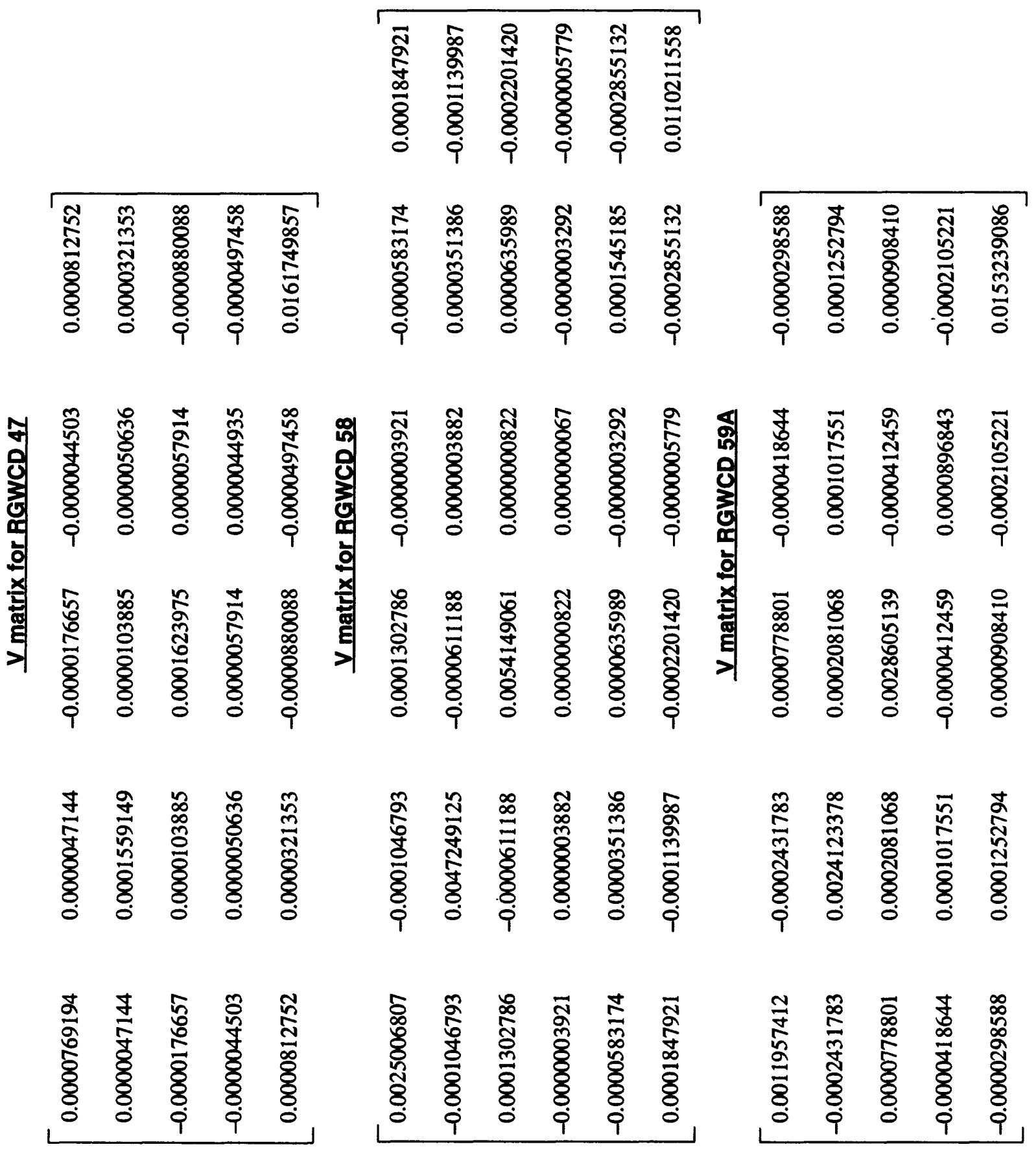

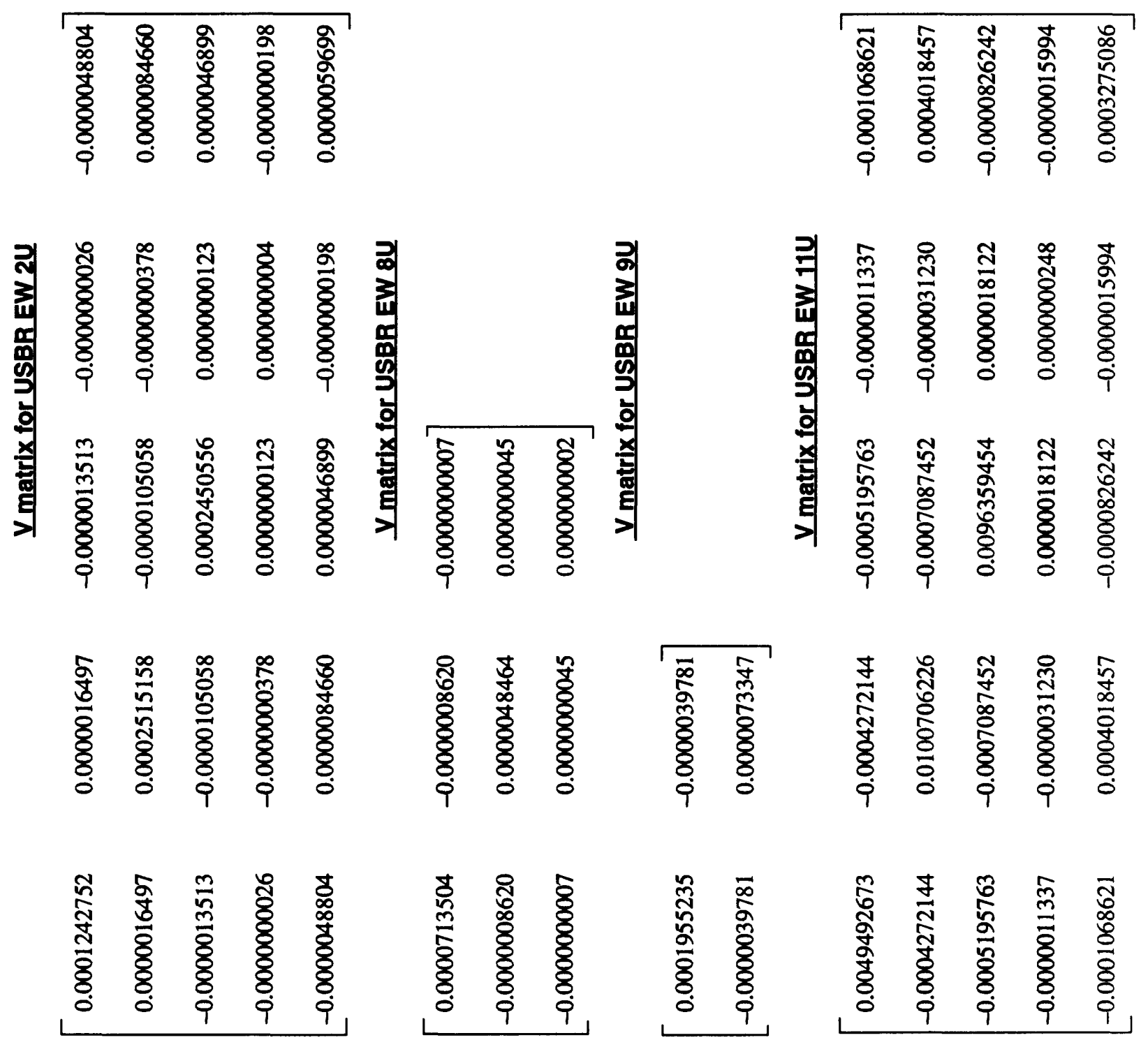

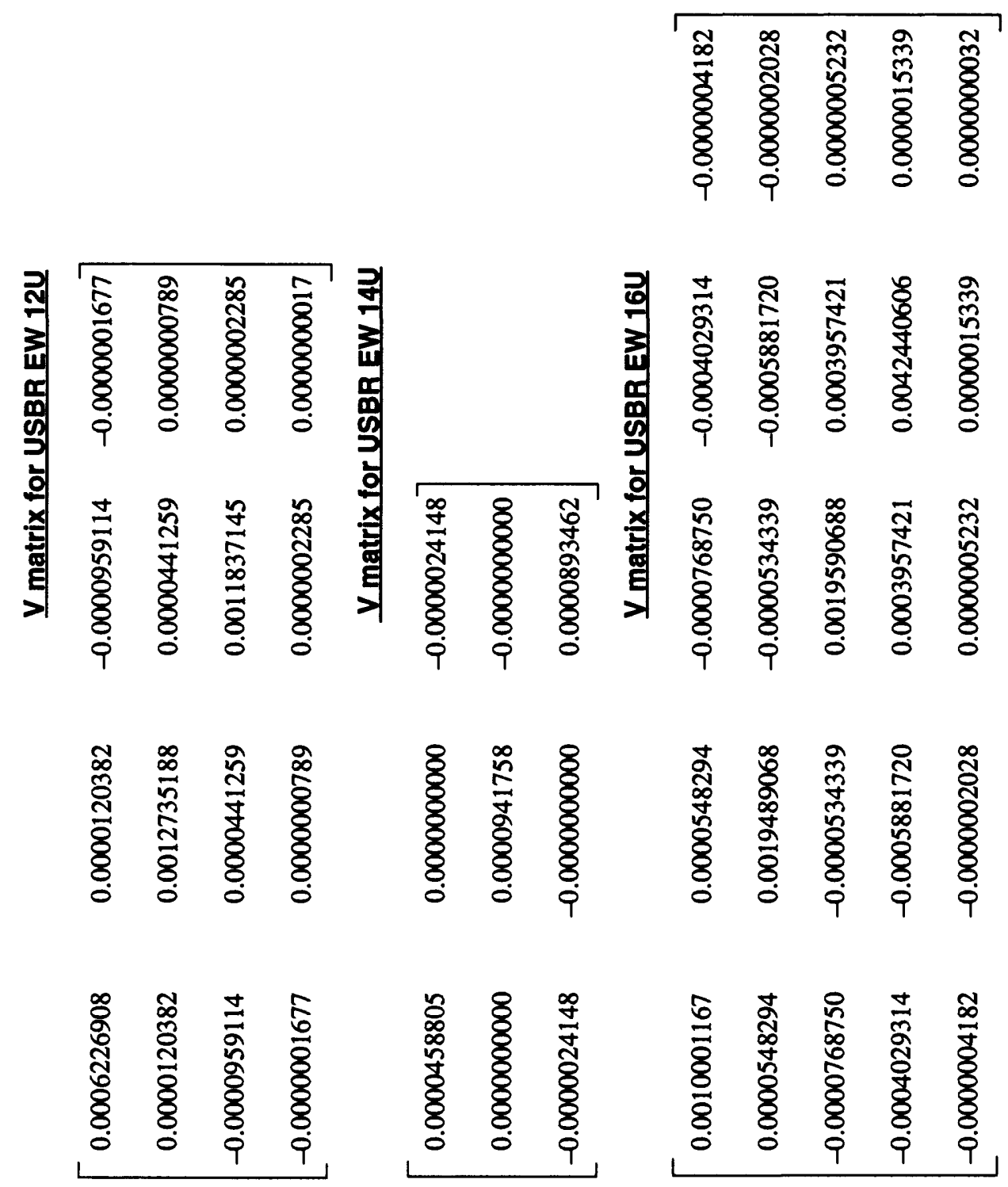

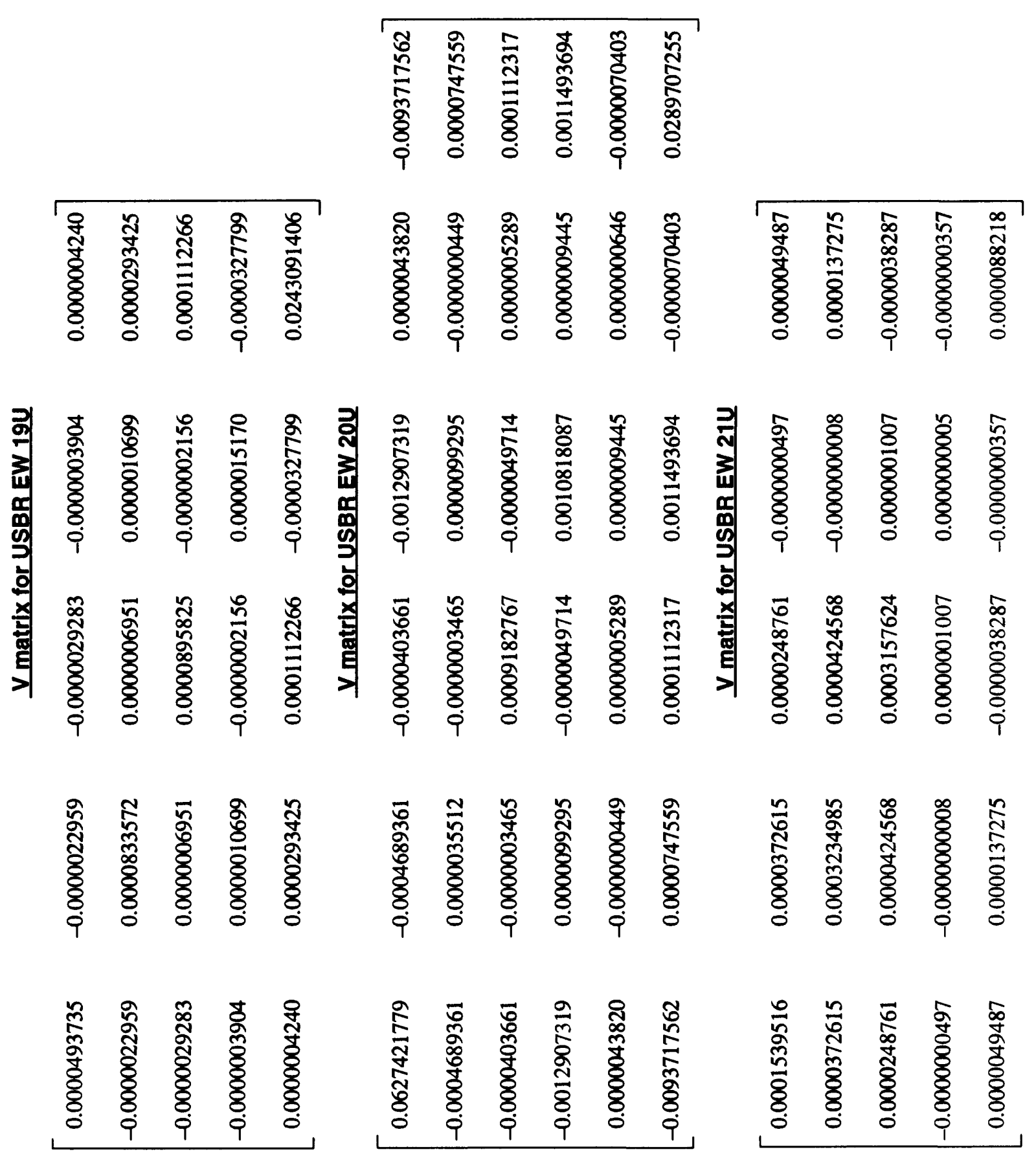

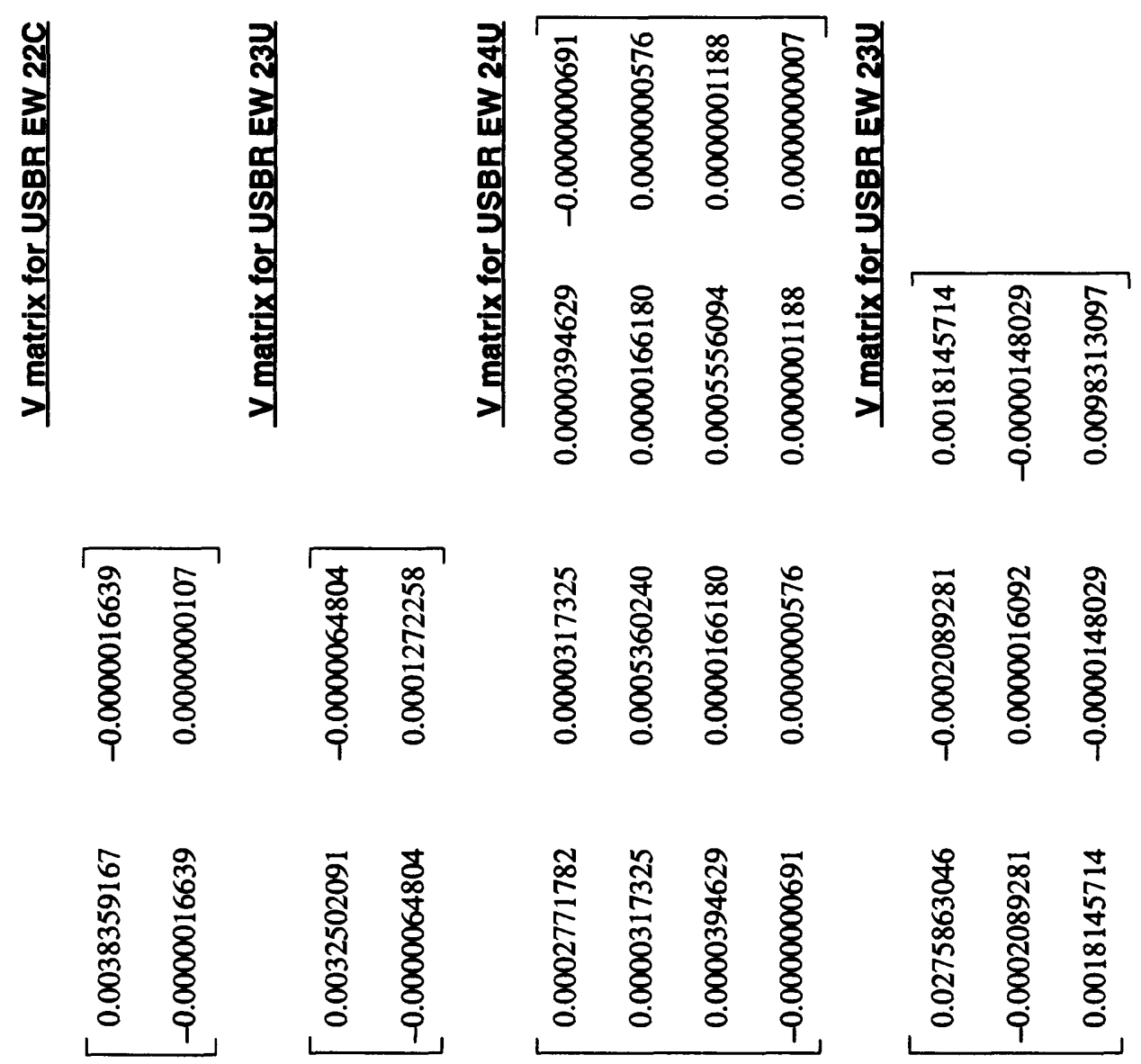


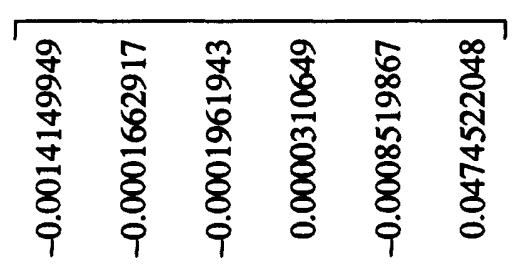

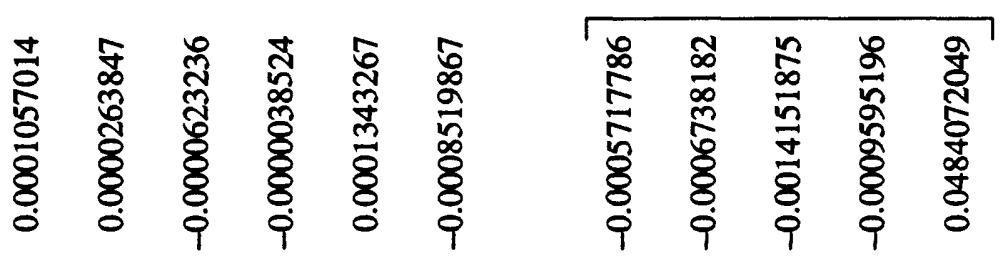

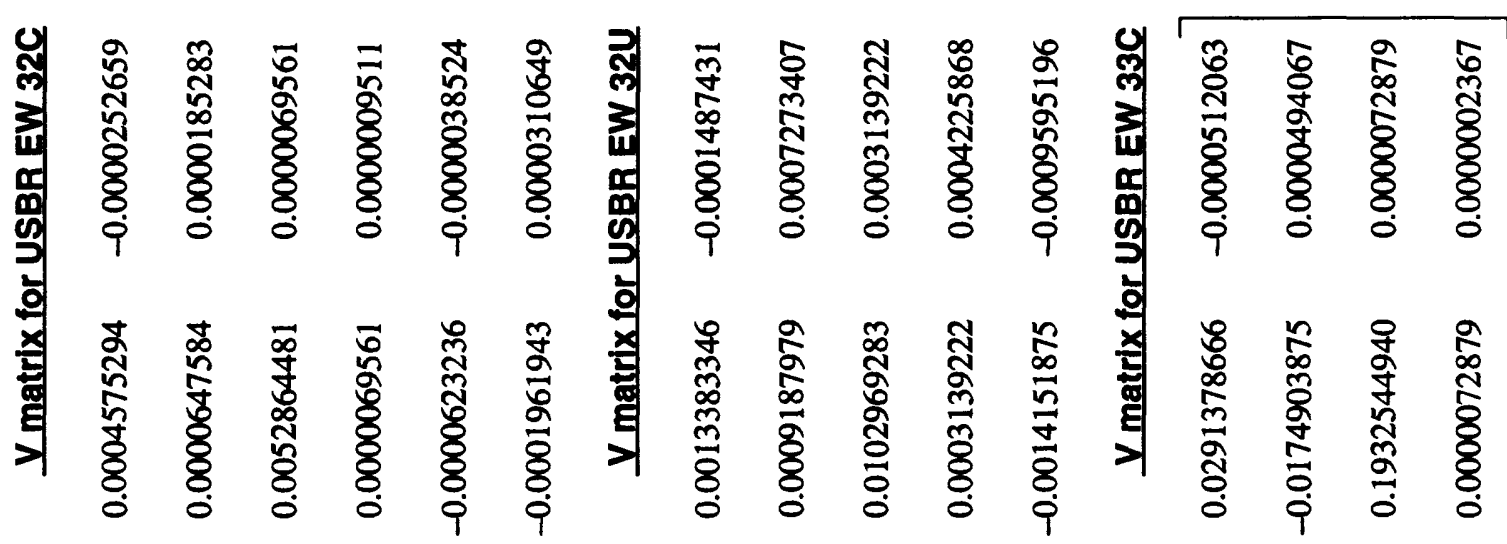

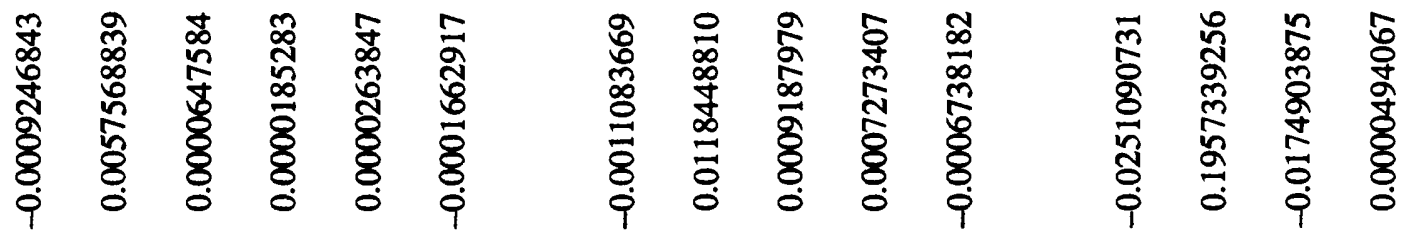

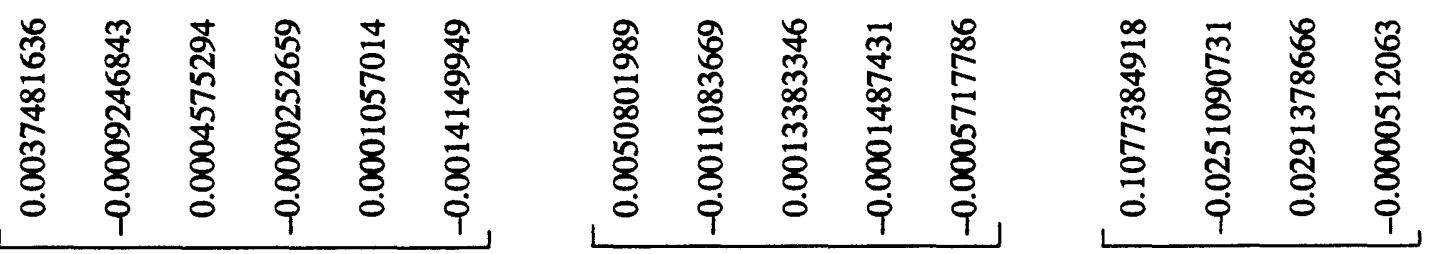




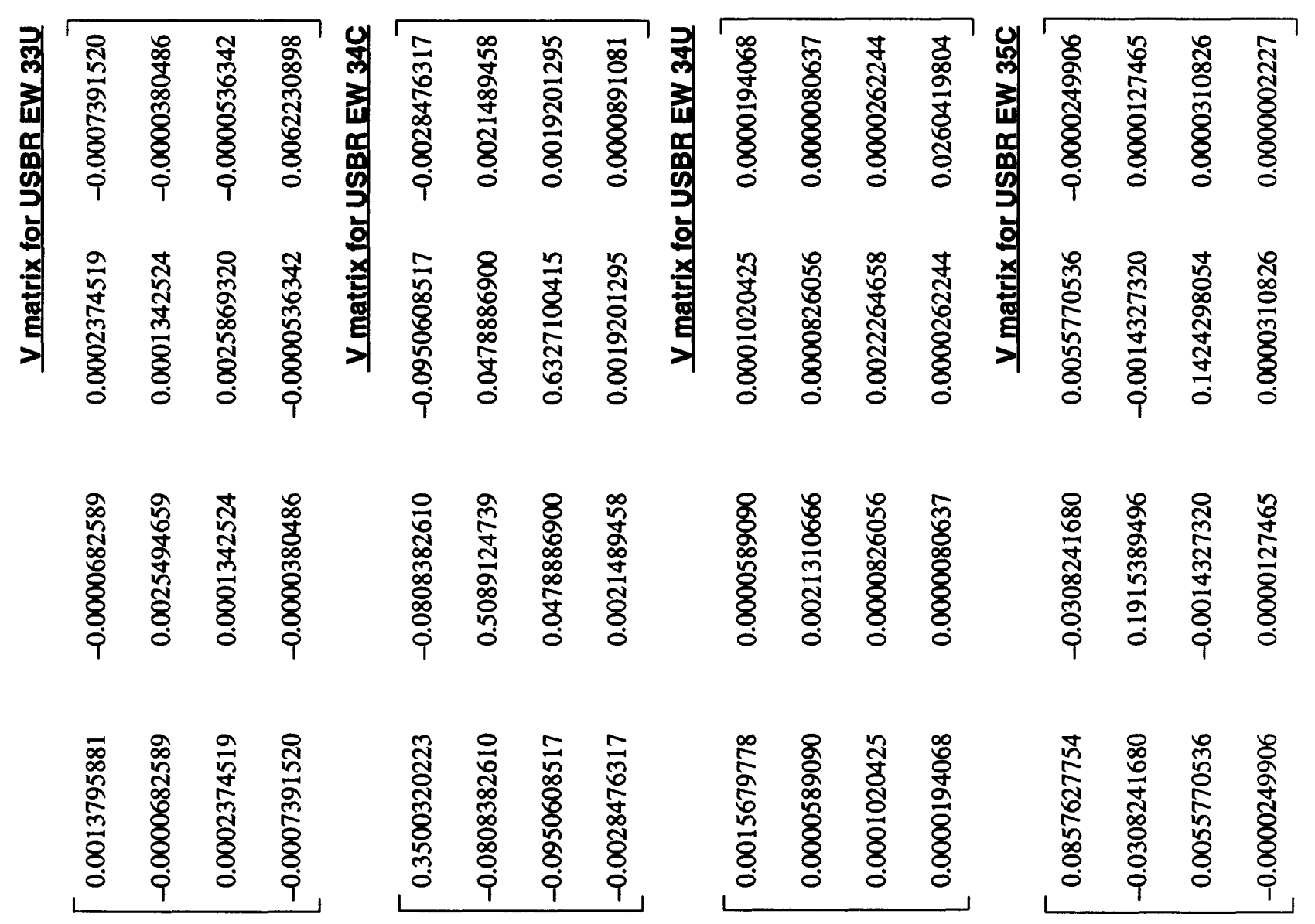



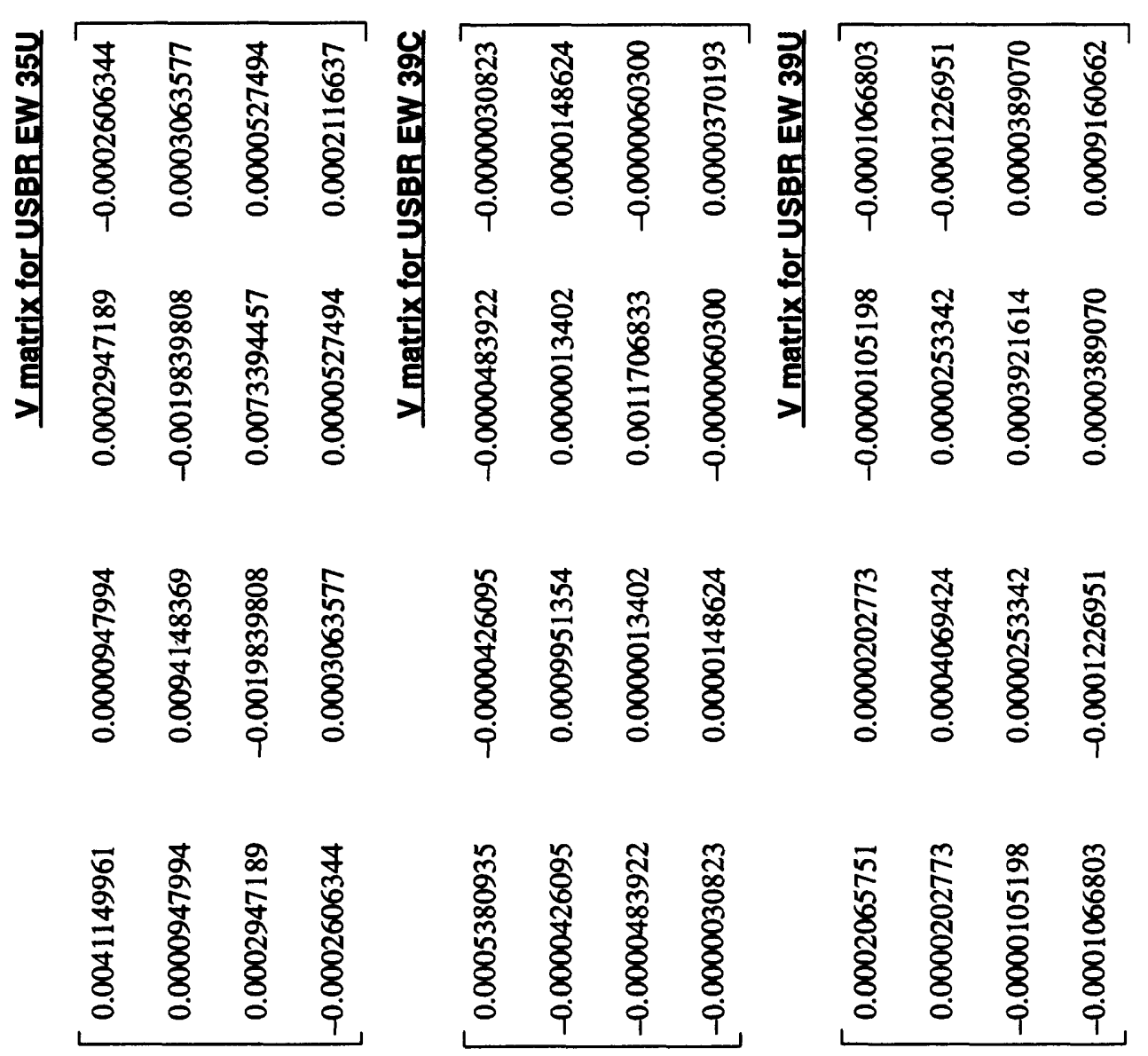

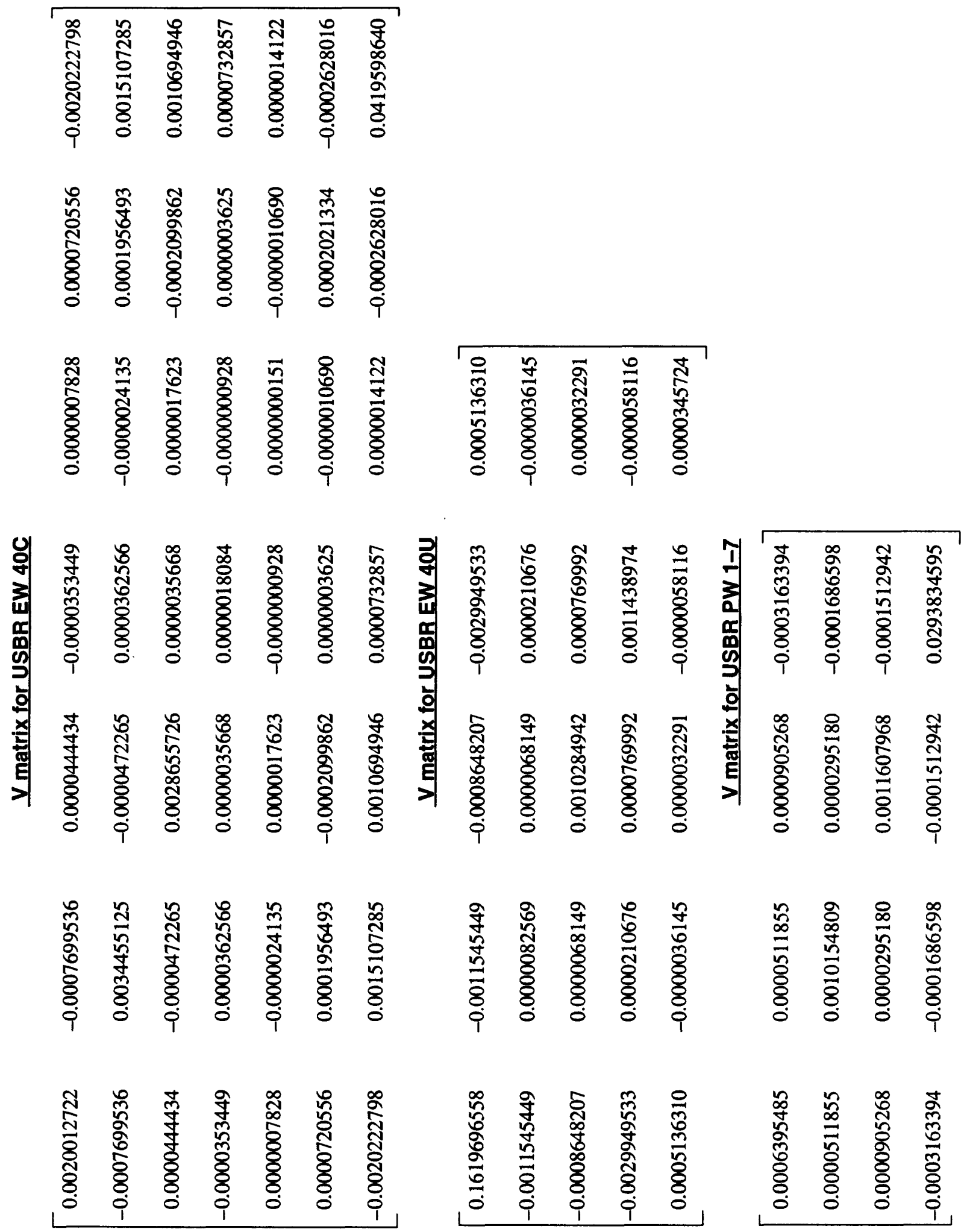

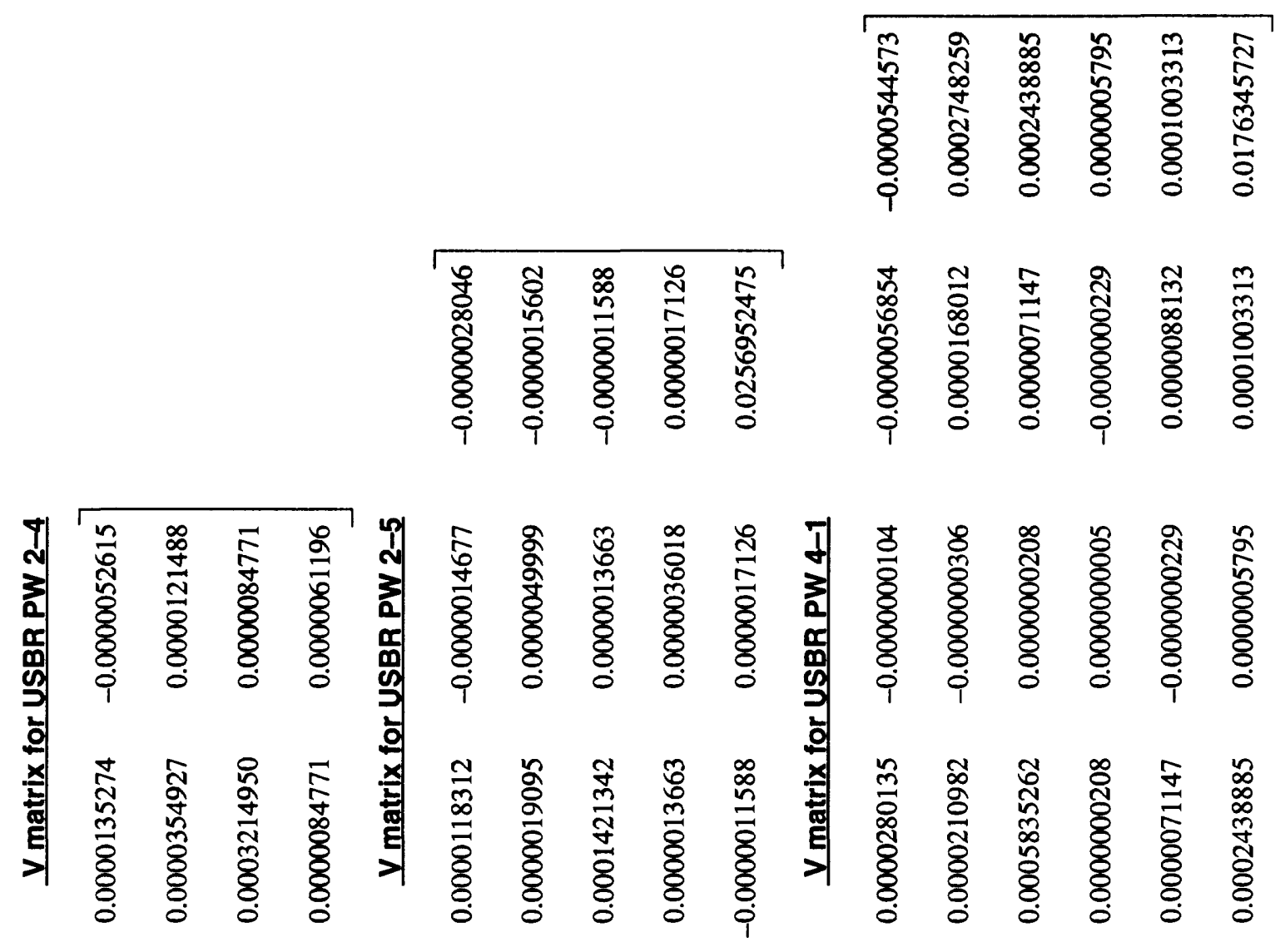

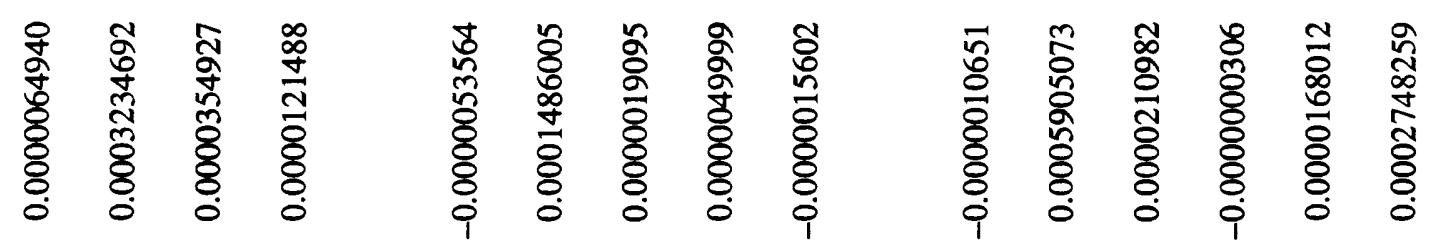

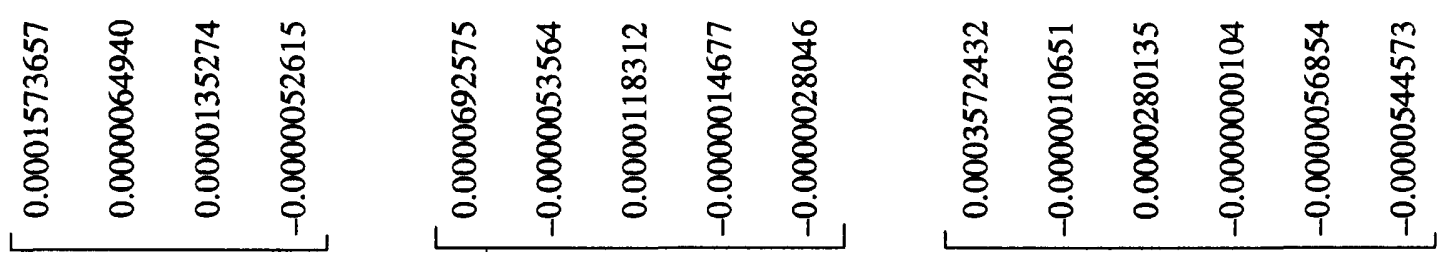




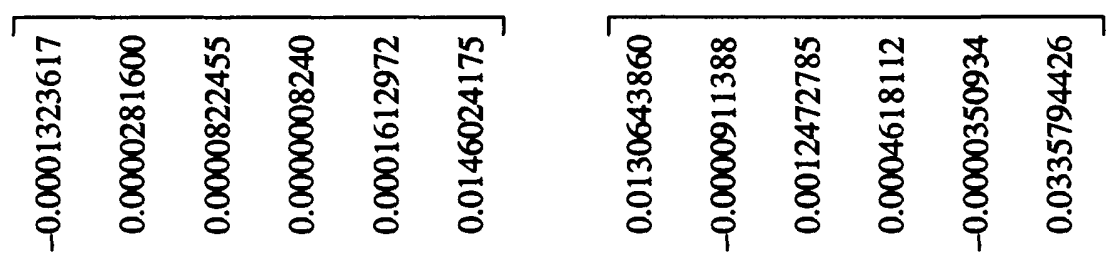

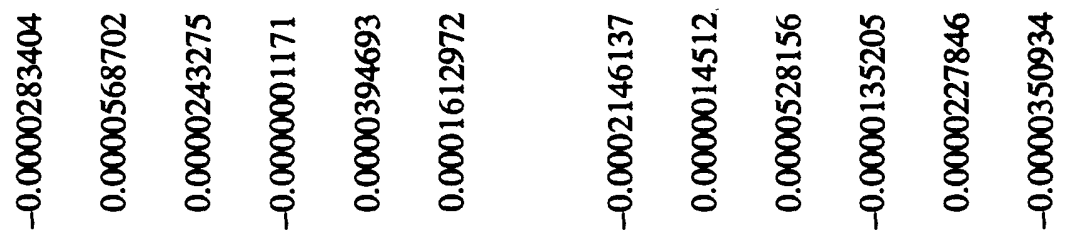
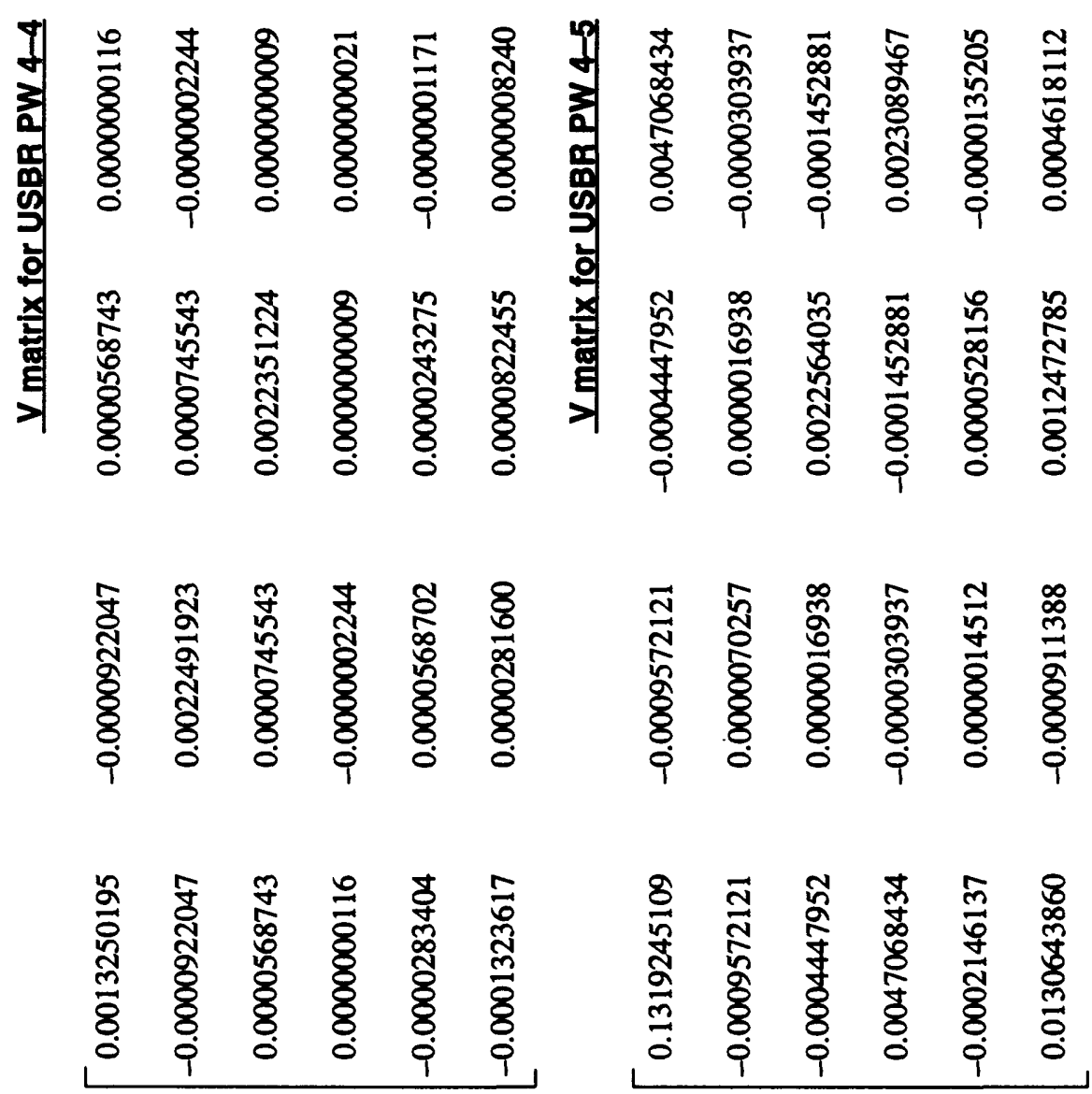


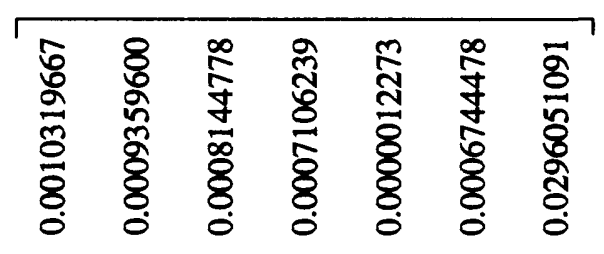

IIIIIIII
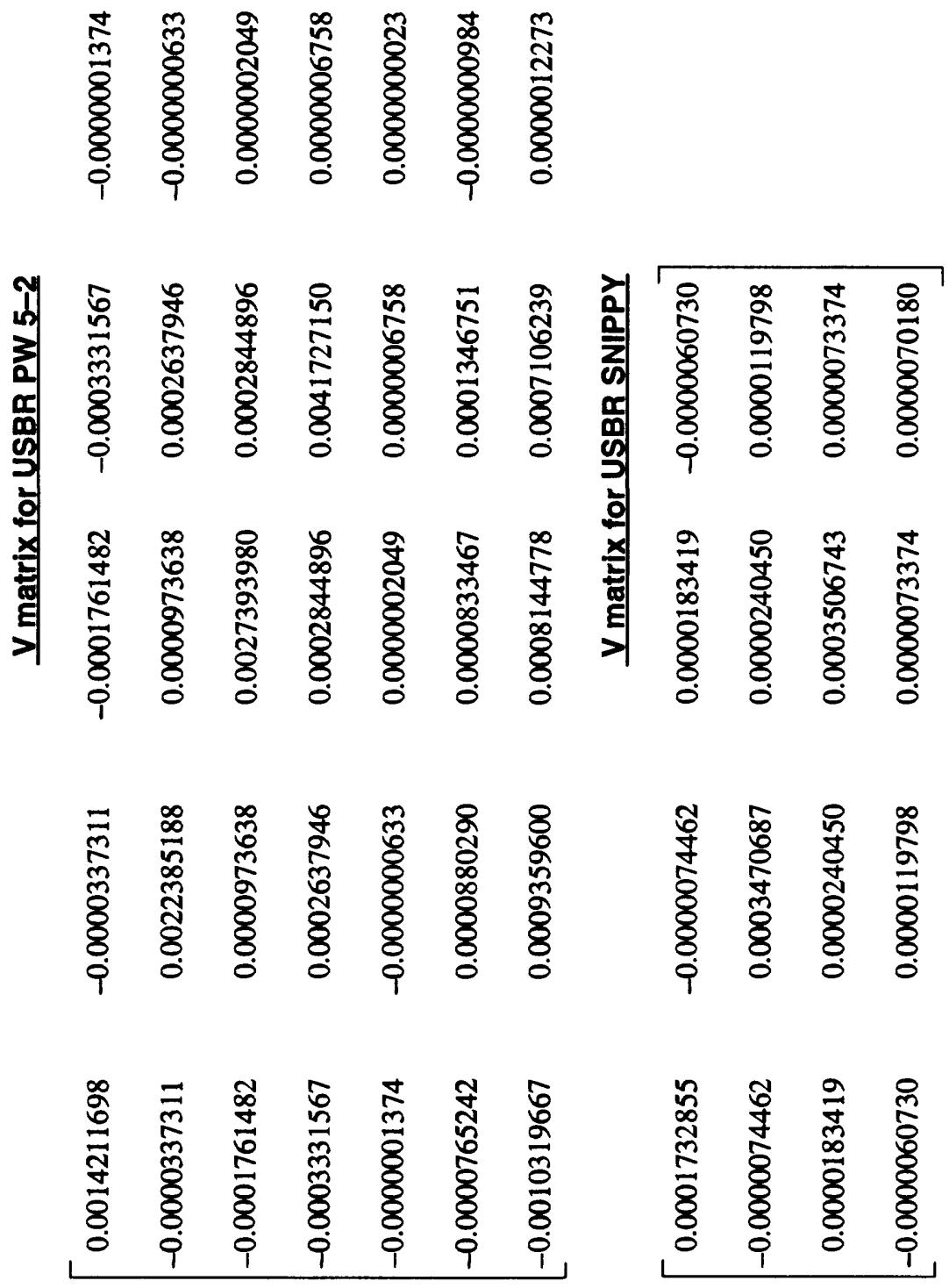